Portland State University

PDXScholar

\title{
The introduction of European and Asian cultural materials on the Alaskan and Northwest coasts before 1800
}

Herbert Kyle Beals

Portland State University

Follow this and additional works at: https://pdxscholar.library.pdx.edu/open_access_etds

Part of the Anthropology Commons, Indigenous Studies Commons, and the United States History Commons

Let us know how access to this document benefits you.

\section{Recommended Citation}

Beals, Herbert Kyle, "The introduction of European and Asian cultural materials on the Alaskan and Northwest coasts before 1800" (1983). Dissertations and Theses. Paper 3249.

https://doi.org/10.15760/etd.3240

This Thesis is brought to you for free and open access. It has been accepted for inclusion in Dissertations and Theses by an authorized administrator of PDXScholar. Please contact us if we can make this document more accessible: pdxscholar@pdx.edu. 
AN ABSTRACT OF THE THESIS OF Herbert Kyle Beals for the Master of Arts in History presented February 21, 1983.

Title: The Introduction of European and Asian Cultural Materials on the Alaskan and Northwest Coasts before 1800 .

APPROVED BY MEMBERS OF THE THESIS COMMITTEE:

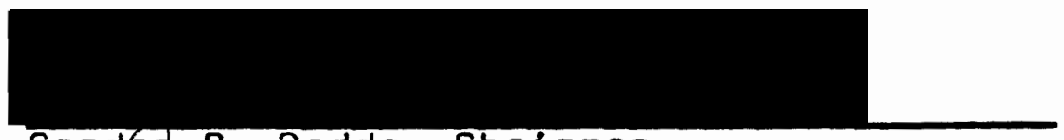

Cardon B. Dodds, Chairman
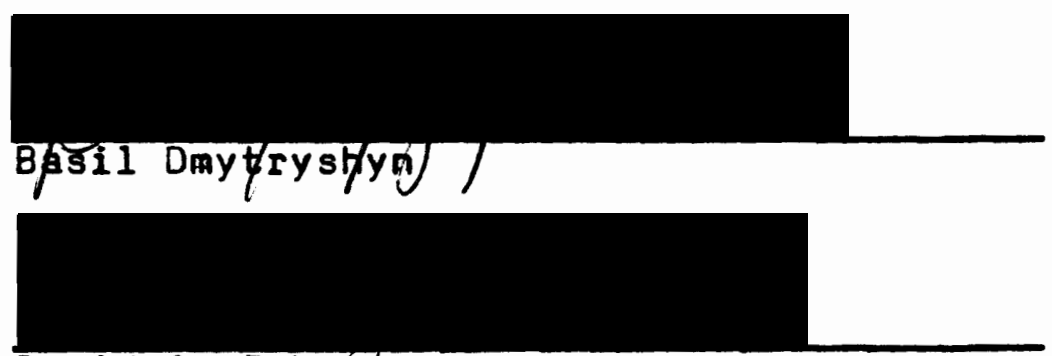

David A. Johnsón
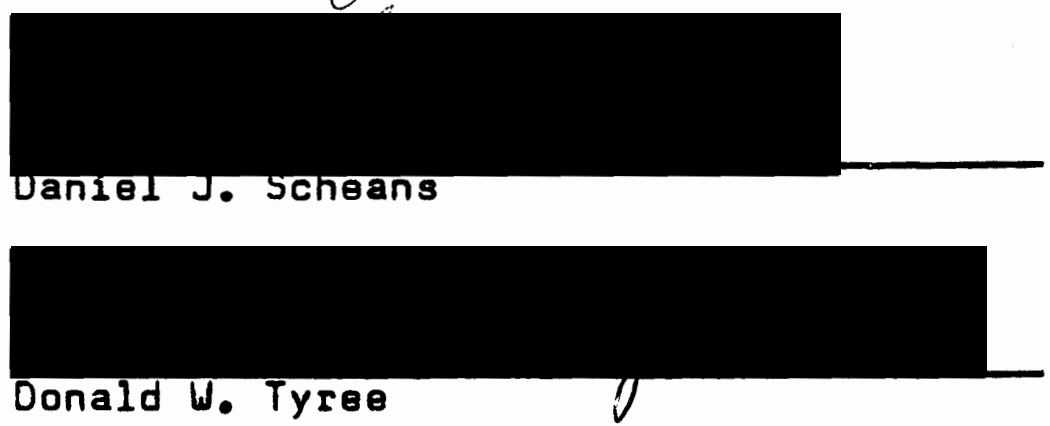

This thesis concerns the introduction of exogenous cultural materials among the native inhabitants of the Alaskan and Northwest coasts prior to the end of the 18th 
century. It is an investigation of the sources of these materials and the manner and chronology of their introduction. The research is based primarily on data drawn from accounts of native life by explorers and fur traders who visited the coasts of northwestern North America in the 18th century. These accounts are supplemented by ethnologic and archaeologic data collected by anthropologists in the 19th and 20th centuries.

The history of pre-1800 contacts between Europeans and the natives of coastal northwestern North America is surveyed for information suggesting the pre-contact presence of exogenous cultural materials among the latter, as well as to establish the chronology and nature of the process by which such materials were introduced subsequent to the earliest documented contacts. In part, this investigation is a rëxamination of a thesis first advanced in 1741 by naturalist Georg wilhelm Steller that iron tools and weapons had been traded across Bering Strait well before Europeans had established direct contact with Alaskan natives. It also seeks to establish a basis for distinguishing spurious from authentic claims about prehistoric or protohistoric trans-Pacific contacts in northwestern North America.

While the results of this work support the plausibility of Steller's thesis, they also suggest that other pre-contact sources of European and Asian cultural materi- 
als existed, to say nothing about sources of aboriginally fabricated metallic articles. The thesis advanced by T. A. Rickard (1939) that trans-Pacific drift of wreckage proceeding from damaged, derelict, or off-course ships of various nationalities operating in the western Pacific (or attempting to cross the North Pacific from west to east) is seen as a particularly significant source. Little if any evidence is adduced of intentional voyaging from Asia specifically to northwestern North America before the Russian discoveries of the 1730 s and 1740 s. Pre-1800 reports of Asian cultural materials in Alaska or elsewhere on the Northwest Coast are seen as primarily the result of accidental or off-course voyages, wreckage from damaged or derelict ships, or late 18th century fur trading voyages that embarked from Asian ports. The widespread distribution of both European and Asian cultural materials in coastal northwestern North America at the end of the 18 th century is seen as a reflection of the aboriginal trading system's power to move such exotic articles over long distances. 
THE INTRODUCTION OF

\section{EUROPEAN AND ASIAN CULTURAL MATERIALS}

ON THE ALASKAN AND NORTHUEST COASTS

BEFORE 1800

by

HERBERT KYLE BEALS

A thesis submitted in partial pulfillment of the requirements for the degree of

MASTER OF ARTS

in

HISTORY

Portland State University

1983 
TO THE OFFICE OF GRADUATE STUDIES AND RESEARCH:

The members of the Committee approve the thesis of Herbert Kyle Beals presented February 21, 1983.

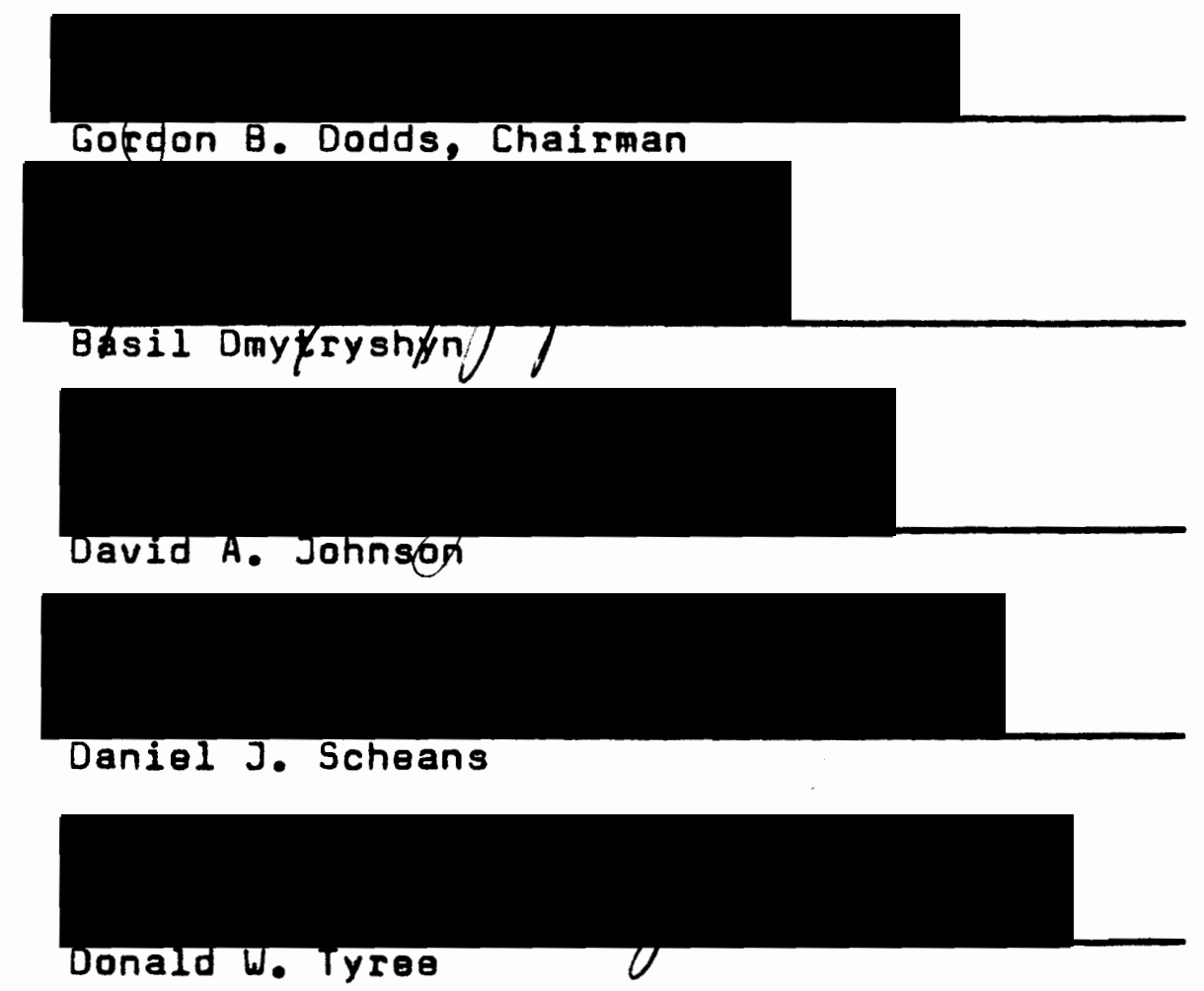

APPROVED:

Bernard V. Burke, Head, Department of History 
TABLE OF CONTENTS

PAGE

LIST OF MAPS . . . . . . • • • • v v CHAPTER

I INTRODUCTION . . . . . . . . 1

Notes ............. 5

II BACKGROUND ............. 7

Notes ................ 18

III RUSSian voYages .............. 22

Notes ................... 49

IV SPANISH VOYAGES .......... 58

Notes ............. 72

v ENGLISH VOYAGES ........... 76

Notes .......... 106

VI FRENCH VOYAGES ............... 115

Notes ........... 126

viI AMERICAN VOYAGES ............. 129

Notes ........... 153

VIII MYTHS AND LEGENDS ............... 164

Notes ............... 175

IX MATERIALS FROM ASIA ........... 179

Notes ................. 198 
X CONCLUSION • • • • . . . . . . . 204 Notes •. . . . . . . . . . 221 APPENDIX: CHRONOLOGY OF VOYAGES TO THE ALASKAN AND NORTHUEST COASTS, 1648-1799 • • • • 227

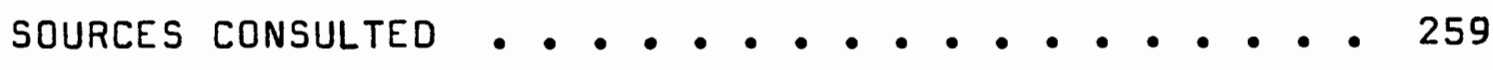




\section{LIST OF MAPS}

MAP

PAGE

1. KAMCHATKA AND THE ALEUTIAN ISLANDS • • • • 247

2. SOUTHUEST ALASKA AND THE ALEUTIAN ISLANDS • 275

3. UPPER NORTHWEST COAST . . . . . . . . 276

4. LOWER NORTHWEST COAST • • • • • • • • . 277 


\section{CHAPTER I}

\section{INTRODUCTION}

Georg Wilhelm Steller, a German-born naturalist, and Thoma Lepikhin, a Russian Cossack, are among the first Europeans known to have landed on Alaskan soil. They were members of the expedition commanded by Vitus Bering (a Dane by birth) that sailed from Kamchatka in 1741 on a voyage of discovery to the northwestern coast of America. Bering's ship, the Sv. Petr (St. Peter), was anchored off an island (today called Kayak Island) on the southern Alaskan coast when Steller and Lepikhin went ashore with some crewmen in a small boat loaded with empty water casks to be refilled. The date was July 20,1741 , as reckoned by the old-style Julian calendar. 1

Steller had to convince a reluctant Bering to ellow him ashore to perform the scientific observations that seemed so important to the 32-year-old naturalist. The landing produced several botanical and zoölogical discoveries, 2 and there was evidence of human habitation, but Steller encountered no natives face to face. It would not be until August $30\left(0 . S_{.}\right)$, when the expedition reached the Shumagin Islands, 3 that Steller had his first opportunity 
to observe Alaskan natives first-hand. In describing these people, whom he appropriately called "Americans," Steller was immediatley drawn into an issue that would intrigue and confound later explorers and visitors to northwestern North America: these native "Americans" already possessed iron implements. He described his discovery and advanced what must be the first explanation to account for it:

Two had hanging on their belt, like the Russian peasants, a long iron knife in a sheath of very poor workmanship - . From the distance I observed the nature of this knife very carefully as one of the Americans unsheathed it . . I It was easy to see that it was not like any European product. From this, then, might be concluded that the Americans not only have iron ore, of which thus far few or no traces at all have been discovered in Kamchatka, but that they also know how to smelt and work it. On the other hand I know from quite reliable information that the Chukchis traded from the second Chukchi island with America and that.. - this trade is still carried on by the inhabitants of the islands; the principal articles are knives, axes, lances, and iron arrow points, which the Chukchis acquire at a very high price from the Russians at Anadyrsk and exchange with the Americans at a many times higher price for sea otters, martens, and foxes. 4

Even if Steller had only his own sparse observations and "reliable" second-hand information to go on, he still seems to have sensed the central question at issue: how had the competing roles of trade networks, as opposed to independent technological invention, shaped cultural changes on the North American northwestern coast? The body of evidence and theory bearing on this subject has grown significantly --if not always systematically--since 1741, with successive waves of explorers, fur hunters and traders, and ethnolo- 
gists. It is to this expanded historical and anthropological record that this inquiry will turn in reconsidering Steller's thesis--namely, that European and Asian cultural materials were being traded from Siberia to Alaska well before the height of the maritime fur hunting and trading activities of the last half of the 18 th century.

The method of this study essentially will be to trace the course of pre-1800 historic contacts between Europeans and the coastal natives of northwestern North America to see what it reveals about the presence of pre-contact exogenous materials among the latter. Emphasis will be placed on early events in the North (i.e., above the 50th parallel), since the process of European-aboriginal contact had its origin there. The historic contact-period itself brought a flow of foreign goods, introduced at first by Russian explorers and promyshlenniki, 5 augmented somewhat later by Spanish, English, and French explorers, and finally swollen to a flood by English, French, and American commercial maritime fur traders. The materials introduced among native populations from these historic sources have sometimes been mistaken for evidence of earlier unrecorded or prehistoric contacts, or are cited to support various theories concerning early trans-Pacific contacts. ${ }^{6}$ Thus, an understanding of the chronology and nature of the process by which exogenous materials were introduced during the historic contact-period is helpful in distinguishing 
spurious from authentic claims.

Since this process unfolded in a setting of rival national interests, aims, and motives, this inquiry is structured in large part around the explorers and fur traders of several nationalities who made voyages to the coast. Their respective stories are told in the journals, logs, or other participant or near-contemporary accounts of the voyages, and these will be relied upon as the principal documentary sources in this study. These historical sources will also be supplemented with data obtained through anthropological research in the late 19th century and 20 th century, including oral testimony of the natives themselves, as well as archaeological evidence.

Before moving to a detailed consideration of the evidence, some background on the geography, ethnography, and contact-period history of the Alaskan and Northwest coasts seems appropriate. 
1old-style Julian dates will henceforth be identified by the letters "O.S." in parentheses. Gregorian or new-. style dates in the 18 th century were approximately 11 days later, so the landing at Kayak Island would have been on July 31,1741 , by the calendar generally in use today.

2 steller describes this landing in his journal (see Frank A. Golder, Bering's Voyages, II, 36-53). Steller's several discoveries, as well as his famous recognition of a blue jay "that proved to me that we were really in America," are discussed by Leonhard Stejneger, Georg Wilhelm Steller, pp. 269-271. Also see Golder, Bering's Voyaqes, II, 57-60.

3 According to the log of the Sv. Petr a sailor named Nikita Shumagin died on one of these islands August 31 $(0.5$.$) . He was buried there and the island named for him.$ The name Shumagin, however, has since come to apply to the archipelago in which the island is located (on the south coast of the Alaska Peninsula). The island on which Shumagin was buried is today called Nagai (see Golder, I, $142)$.

${ }^{4}$ Golder, II, 97-99.

${ }^{5}$ This term, for which there is no really good equivalent in English, is used to describe the individuals who engaged in the Siberian fur trade as trappers, hunters, or traders. They were loosely distinguished from so-called "service-men," who included various military servitors and the rank and file of Cossacks. The promyshlenniki, unlike the "service-men," were not directly in government employ, although their transportation might be provided by the state and they collected tribute payments called iasak on behalf of the Russian crown. They were, in any case, not independent frontiersmen beyond government control, such as those of the American West (see Raymond H. Fisher, The Voyage of Semen Dezhnev in 1648, P. 43).

6 Iron swords fabricated aboard an American fur trading vessel in 1794 and traded among the Columbia River natives have given rise to more than a few exotic theories as to their origin (see Roy Jones, Wappato Indians of the Lower Columbia River Valley, pp. 113-119). Chinese coins have sometimes been claimed as evidence of very early trans-Pacific voyaging, without proper recognition of the fact that they were commonly traded by maritime fur traders (see J. Macmilian Brown, Peoples and Problems of the Paci- 
fic, II, 67). 
CHAPTER II

BACKGROUND

From Cape Mendocino on the California coast northward to the Bering Sea, the northwestern littoral of North America is a zone richly endowed with material resources peculiarly favorable to human societies lacking an agricultural economic base. This natural bounty, which ranges from an abundance of marine and land animals to the wood supplied by vast forests, is the result of special geographic circumstances. Most of the coast is either deeply indented with narrow fjords, sheltered behind complex systems of off-shore islands, or traversed by westuard-flowing rivers carrying major migratory fish runs. 1 Except in the far north, the warming influence of the North Pacific Current, an eastward extension of the Kuroshio or Japan Curent, protects the coast from extreme or prolonged winter cold. ${ }^{2}$ With winds off the Pacific supplying an abundance of moisture, conditions on the coast below the 60th parallel are nearly ideal for coniferous porests. 3

The aboriginal peoples that flourished along North America's northwestern shores practiced a hunting-pishing economy, yet their cultures reached levels of material 
wealth that rivaled those with agricultural food production. Between the Tlingits of Yakutat Bay at $60^{\circ} \mathrm{N}$. latitude in southeastern Alaska and the Yuroks of Trinidad Harbor $2,200 \mathrm{~km}$. away at the $40 \mathrm{th}$ parallel in northern California a common bond existed despite differing languages and physical characteristics. They, together with at least 23 other linguistic groups in between, 4 shared, as anthropologist Philip Drucker has written, "a number of Pundamental cultural patterns that, in combination, comprised Northwest Coast civilization." 5 The particularly generous bounty of sea and land in the territory occupied by the Tlingit enabled them to be wealthier than many of their distant southern cousins. But each group needed similar implements, weapons, and methods to extract a living from essentially the same natural resources, however their relative abundance may have differed from place to place.

North of the 60th parallel and west of the Tlingit's Yakutat outposts, the climate and land resources are less beneficent. Westward of Alaska's Prince William Sound and Kenai Peninsula coastal stands of trees become scattered and sparse, eventually vanishing altogether. The Alaska Peninsula, Kodiak Island, and the entire length of the Aleutian Island chain supports negligible forest resources. The Alaskan coast facing the Bering Sea is similarly sparsely wooded. In these bleak lands, the aboriginal people derived their livelihood almost exclusively from marine re- 
sources, which are abundant despite the environmental severity. 6 These Eskimo-Aleut peoples, whose way of life and physical characteristics are distinct from those of the Northwest Coast Indians, also developed a material culture by no means inferior to many of their southern and eastern neighbors. They substituted ivory and bone for wood, and hunted a wide variety of sea mammals, instead of the large land game that supplemented the diet of Northwest Coast Indians. The Alaskan Eskimos and their close relatives, the Aleuts, in fact participated in a remarkably adaptive culture that ranged from the Chukotskii Peninsula of eastern Siberia eastward across the northern habitable limits of the North American continent to Hudson Bay and Greenland.? "Eskimos," as Has-Georg Bandi points out, "are the only native population living in both the 0ld and New Worlds." 8 Despite differences in their physical appearances and cultures, the Alaskan Eskimos (including Aleuts) and Northwest Coast Indians nevertheless share enough traits to suggest that they may have common roots in the past. Drucker, in writing of the possible antecedents to Northwest Coast cultures, observed that

the ancestral culture of the Northwest Coast, whether it was specifically "Eskimo" with all the cultural and ethnic connotations of the term, or, as may have been the case, was a slighly watereddown derived version, nonetheless was based on the essential patterns of ancient Western Eskimo civilization: it was a culture oriented toward the sea, with an emphasis on navigation and the hunting of sea mammals, and a tradition of neat craftsmanship 
in working wood and bone. 9

Contact between natives of northwestern North America and Europeans occurred relatively late compared with other parts of the continent. While Spanish and English vessels probably sailed off sections of northern California and along the Oragon coast in the 16 th century, ${ }^{10}$ it was not until Russian penetration of northeastern Siberia in the 17 th and early 18 th centuries that the possibility of contacts with Europeans began to arise. The much-debated voyage of a little-known Russian Cossack named Somen Dezhnev in 1648 may have recorded the earliest European sighting of Eskimos inhabiting the Asiatic side of Bering Strait. ${ }^{11}$ Vitus Bering, during his first Kamchatka expedition to explore the Bering Strait vicinity, mentions an encounter in August, 1728, at Cape Chukotskii (near Siberia's eastern extremity) with "eight men who claimed to be Chukchi."12 These may have actually been Asiatic Eskimos, since the name "Chukchi" seems to have been applied by the Russians generally to all natives in the Bering Strait vicinity. Four years later, Mikhail Gvozdev, in leading an expedition to find the bolshaya zemlya or "big country" (i.e., the Alaskan mainland), rumored to lie across Bering Strait, wrote:

About three $0^{\prime}$ clock of the afternoon of August 21, $[(0.5$.$) 1732] we sailed for the "large country" and$ anchored about four versts $[4.28 \mathrm{~km}$.] from its shore. It was now Fedorov's watch, and he, without consulting anyone, gave orders to weigh anchor and approach the southern point of the shore. From there we could see huts, but inspite of our best efforts we did not come as close to them as we wished.. - we were 
obliged to stand out to sea on a southwest course and by doing so we came to the fourth island on the 22nd. - - there came to us from the island a Chukchi in a leather boat which had room for but one man. - - He told us that Chukchi lived in the "large country," where there were forests, streams, and animals. We had no opportunity of going ashore, and from the distance we could not tell whether all that he told us of the "large country" was true or not. 13

In all likelihood, this account describes the first encounter between Europeans and natives residing in northwestern North America.

Bering's second Kamchatka expedition in 1741 resulted in Russian contacts with natives (probably Aleuts) in the Shumagin Islands off the south coast of the Alaska Peninsula and at Adak Island in the Aleutians. ${ }^{14}$ It also produced the first recorded sighting by Europeans of people belonging to one of the Northwest Coast Indian cultures (probably Tlingits). The expedition's two ships, the Sv. Petr commanded by Bering and the Sv. Pavel under Aleksei Chirikov, became separated and made different landfalls on the American coast. Chirikov's first encounter with natives occurred during an attempted landing near Lisiansky Strait at the north end of Chichagof Island in southeastern Alaska, well within the limits of Tlingit territory. ${ }^{15}$ Russian contacts with Aleutian Island inhabitants were renewed in 1745,16 and they became numerous and wide-ranging under increasing pressure to exploit the region's fur resources. Between 1745 and the end of the 18th century, at least 97 Russian 
fur-trading vessels are believed to have visited the Aleutian Islands, the Alaskan mainland, or areas inhabited by Northwest Coast Indians. 17

European penetration of the North American northwestern coast from the South was initiated by the Spanish in 1774. Juan Pérez, in the frigate Santiago, led the first of thres expeditions commissioned by the viceroy of New Spain. Antonio María de Bucareli, to investigate the coastline north of California. This voyage and its two immediate successors in 1775 and 1779 appear to have been undertaken largely to counter the Russian presence in the North, which in Spain's perception was a threat to its west coast North American possessions and the North Pacific trade route by which commodities from the Philippines reached them. 18 The viceroy's instructions for the expedition of 1774 ordered Pérez to make a landing at $60^{\circ} \mathrm{N}$. latitude, following which he was to explore the coast southward looking for foreign settlements. 19 Instead, the Santiago made landfall at Langara Island, the northernmost of the Queen Charlotte Islands off the British Columbia coast, just above the 54 th parallel late in July, 1774.20 Pérez was unable to send a landing party ashore, but he and his crew were met by some 21 canoes full of Northwest Coast Indians (probably Haida). A brisk trade--the first recorded anywhere between California and southeastern Alaska-mensued: the sailors purchased articles such as fish, pelts, native hats and caps, and 
"blankets beautifully woven and made" in exchange for wornout clothing, knives, and beads. 21 Pérez probably was looking for evidence of Russian contact; but as far as he knew he and his crewmen were the first Europeans seen by the natives. It must have thus been with some surprise and curiosity that, in describing their encounter, he remarked:

I noted among them some things made of iron in the canoes, such as cutting instruments like half a bayonet and a piece of a sword. - . By signs, they asked for long swords or machetes, but finaliy they settled for some knives that the sailors gave them in exchange for pelts...

Among the 21 canoes, two came that were full of women, some with infants at the breast, most appearing quite fair and white, many of them wearing bracelets of iron and copper, and some with rings of the same materials. 22

In the following year, 1775, a second of the Bucarelisponsored voyages commanded by Bruno de Hezeta ${ }^{23}$ had a similar experience at the southern extreme of the territory occupied by Northwest Coast Indians. The two ships of this expedition, the Santiago and Sonora, anchored at Trinidad Harbor on the northern California coast among the Yurok Indians for ten days in June. During this time, they witnessed native life in some detail, much of which was recorded in the several accounts of the voyage. 24 Hezeta observed the use and popularity of iron among the Yuroks, noting their possession of "iron knives, which generally are carried dangling from the neck on a cord." Then, seeking some explanation of their origin, he continued: 
With utmost curiosity, I inquired on several occasions where those iron knives had come from or with whom they had bartered for them. They all responded unanimously by pointing to the coast towards the north, except for one who, with lively and intelligible signs, suggested to us that his had been made from a spike that came from the fragment of a ship the sea had cast upon the beach. 25

Unlike the Pérez sighting in 1774, these iron implements or weapons were not described in specific terms such as "bayonets" or "swords," and so it is less certain if they were of European origin. 26 In the case of the knife said to have been made from a ship's spike, fabrication was clearly aboriginal (although from non-aboriginal iron).

Probably the best known 18th century European visit to the Northwest Coast was that of the two English exploring vessels Resolution and Discovery, commanded by James Cook in 1778. His sojourn at Nootka Sound on Vancouver Island, between March 30 and April 26, and his subsequent exploration of Alaskan waters during the following summer and autumn, focused the attention of English-speaking Europeans on the rich resources of these remote coasts for the first time. 27 Within seven years of Cook's famous last voyage, English and American entrepreneurs began venturing regularly to the Northwest Coast in search of furs, paying for them by what became in time a veritable flood of European and Asian trade materials. As many as 122 trading vessels made the voyage between 1785 and 1799, sailing from ports as diverse as Canton, Macao, Bombay, Calcutta, London, 
Boston, and New York. While they were mostly British or American owned, the ships sometimes sailed under Austrian, Portuguese, or Swedish colors. 28

When Cook was at Nootka Sound in 1778, well before the great tide of European trade had engulfed the Northwest Coast, he too puzzled over the natives' possession and knowledge of metal implements, weapons, and ornaments. He described iron chisels, as long as eight to ten inches, fitted with wooden handles, and apparently used by the Nootkans for woodcarving. As for iron knives, Cook says they were "crooked something like a pruning knife.. - about the breadth and thickness of an iron hoop . . and [they] were certainly of their own forming and helving." 29 In pondering the possible sources of these items he wrote:

Iron which they call seekemaile, a name they also give to $T$ in and all white metal, seemed to be neither scarce nor plenty with them; but we could never learn how or where they came by it. Some account of the Spaniards having visited this coast was published before I left England, but it could not all come from them; it was too common, in too many hands and too well known for them to have had the first knowlidge of it so late as the year 1774 or 75 . Indeed one cannot be surprised at finding iron with all the Nations in America sence they have been so many years in a manner surrounded by Europeans and other Nations who make use of iron, and who knows how far these Indian Nations may extend their traffick one with another. 30

The hypothesis that trade with the Russians in the North, with the English or Americans in the interior of North America, or even with the Spanish in the South could account for the widespread presence of iron and copper 
articles among Northwest Coast natives also appealed to French explorer Jean F. G. de La Pérouse, commander of an expedition sponsored by the French government. During his visit to Lituya Bay in $1786,{ }^{31}$ he saw the Tlingits with iron and copper daggers suspended from their necks (much like the Yuroks at Trinidad Harbor); they also used copper to tip their arrows, as well as for ornaments such as collars and bracelets. 32 Rejecting the likelihood "that these people are acquainted with the method of reducing iron ore to the state of metal," La Pérouse concluded that trade, primarily from Russian sources and perhaps through middlemen, was the best explanation. 33 Noting that the Tlingits at Lituya Bay possessed 34-foot-long framed and skin-covered "canoes," characteristic of the Eskimo-Aleut peoples, La Pérouse reasoned that this supported his theory:

Dimensions so considerable rendered them fit for long voyages. They were covered with seal-skins, after the manner of those of the Esquimaux; which led us to suppose, that Port des Français [Lituya Bay] is a station for trade, inhabited only in the fishing season. It appeared to us possible, that the Esquimaux [more likely Aleuts] in the neighborhood of the island of Schumagin, and of the peninsula explored by Cook, extend their commerce to this part of America, whither they bring iron and other articles, carrying back, with profit to themselves, otter skins, of which the latter [possibly meaning Russians] are so desirous. 34

The observations and speculations of explorers such as Hezeta, Cook, and La Pérouse clearly raise some important questions about trade, technology, and cultural relationstips among aboriginal peoples up and down the north- 
western coasts of America, to say nothing of their relationships with the European strangers they confronted. What was the basis for the spread of these articles, supposedly so unusual for neolithic hunting-fishing peoples to possess? Were supplies of iron and copper raw materials of European or Asian origin, or had they come from some place on the North American coast itself? What role had aboriginal metallurgical knowledge played in this? As a variety of trade objects of definite European or Asian manufacture began to enter the coast with the spread of the fur trade, what was the chronology and geographic pattern of their distribution? 
$1-6$.

${ }^{1}$ Philip Drucker, Indians of the Northwest Coast, pp.

2w. G. Kendrew, The climates of the Continents, pp. $305,309,336$.

${ }^{3}$ Donald Culross Peattie, A Natural History of Western Tress, $D_{\text {. ix. }}$

${ }^{4}$ These include the Haida, Niska, Gitksan, Coast Tsimshian, Haisla, Bella Coola, Heiltsuk, Southern Kwakiutl, Nootka, Coast Salish, Chemakum, Quileute, Klatskanie-Kwalhiokwa, Chinook, Tillamook, Alsea, Siuslaw, Umpqua, Coos, Tututni, Tolowa, Karok, and Hupa. See Drucker, Indians of the Northwest Coast, P. 7 .

5 Drucker, P. 6 .

${ }^{6}$ See, for example, Donald W. Clark, "Technological Continuity and Change within a Persistent Maritime Adaptation: Kodiak Island, Alaska," in Maritime Adaptations of the Pacific, Pp. 172-176.

7 Hans-Georg Bandi, Eskimo Prehistory, pp. 1-17.

${ }^{8}$ Bandi, P. 3 .

9 Drucker, Indians of the Northwest Coast, $p .194$.

${ }^{10}$ Two Spanish ships commanded by Juan Rodríguez Cabrillo may have sighted Cape Mendocino and the coast inhabited by the Yuroks in 1542. Francis Drake's Golden Hind anchgred briefly in a "bad bay" reported variously to be at $42^{\circ}, 43^{\circ}$, and $48^{\circ}$ N. latitude in 1579. But no sighting or contact with natives is mentioned in either case. See Henry R. Wagner, Spanish Voyanes to the Northwest Coast of America in the Sixteenth Century, pp. 72-93; Donald C. Cutter, "Spain and the 0regon Coast," in The Western Shore, pp. 3233; N. M. Penzer (ed.), The World Encompassed, Pp. 49-50; and Wagner, Sir Francis Drake's Voyage Around the World, p. $244, n_{0} 44$.

${ }^{11}$ The reality of Dezhnev's voyage from the Kolyma River on the northern Siberian coast through Bering Strait to the Anadyr River on the Pacific coast has been disputed by Golder in Russian Expansion on the Pacific, 1641-1850, pp. 67-95. Also see Fisher, The voyaqe of Semen Dezhnev in 1648 , pp. 277-289, for a refutation of Golder's thesis. Dezhnev's account describes passing a nos or cape that 
"extends far into the sea," opposite which were two islands. "Chukchi live on them," he continued. "They have carved teeth, [in] holes in the lips [made from] fish tooth bone." This may have been a description of the labrets or circular lip ornaments common among Eskimos, Aleuts, and northern Northwest Coast Indians such as the Tlingit and Haida. See Fisher, P. 54, n. 1; and Drucker, Indians of the Northwest Coast, P. 89.

12 Golder, Bering's Voyages, I, 18.

13 Ibid., I, 23-24.

14 Ibid., I, 273-274, 374; I I, 90-104, See also Aurel Krause, The Tingit Indians, pp. 12-13.

15 fifteen men in two parties were sent ashore, but they disappeared without a trace. They probably perished in the treacherous currents of Lisianski Strait. The encounter with natives occurred during the search for the missing crewmen, July 25 (0.S.), 1741, when two canoes were sighted. Their occupants are recorded as having shouted "Agai, Agai," following which they disappeared from sight. See Golder, Bering's Voyages, I, 296-297, 315-317, 343-346.

16 A fur-hunting expedition, led by Mikhail Nevodchikov between 1745 and 1747, apparently visited the Near Aleutian Islands of Attu, Agatu, and Semichi. Several instances of contact with natives are mentioned involving trade and, unhappily, the killing of a number of the islanders. See William Coxe, The Russian Discoveries Between Asia and America, pp. 29-36; and Raisa V. Makarova, Russians on the pacific, 1743-1799, p. 209 .

17 A list of these ships is given in Makarova, pp. 209216. See also the Appendix of this study, Pp. 227-258. $18_{\text {Since }} 1565$, Spanish vessels called Manila Galleons had annually plied the North Pacific as high as $40^{\circ} \mathrm{N}$. latitude bringing rich Asian cargoes to New Spain from the Philippines. In the early 17 th century, Spanish motives to explore the North American west coast up to or above the 40th parallel seem to have been directed primarily at finding harbors suitable for sheltering Manila Galleons in distress. In the 18th century, the Russian advance from Siberia into Alaska created an even more urgent reason for Spanish exploration of the Northwest Coast. See William Lytle Schurz, The Manila Galleon; Antonio de Morga, Sucesos de las Islas Filipinas, pp. 303-323; W. Michael Mathes, Vizcalno and Spanish Expansion in the Pacific Dcean, 15801630; and Warren L. Cook, Flood Tide of Empire, PP. 41-85. 
19 Manuel P. Servin, trans., "The Instructions of Viceroy Bucareli to Ensign Juan Pérez," California Historical Society Quarterly, 40, No. 3 (1961), P. 240.

20 Accounts of the 1774 Bucareli expedition by the ship's two chaplains, Fray Tomás de la Peña and Fray Juan Crespi, are in Donald C. Cutter, trans. and ed., The California Coast, pp. 136-278. Juan Pérez' account is in his "Diario.? 1774," MS.

21 Pérez, entry for July 20-21, 1774 (author's trans.).

22 Ibid. The use of the words "bayonet" (bayoneta) and "sword" (espada) implies that some of the metal objects were of European manufacture.

23 Accounts of the 1775 Bucareli expedition are in: Francisco Antonio Mourelle, Voyage of the Sonora in the Second Bucareli Expedition, trans. Daines Barrington and ed. Thomas C. Russell; Wagner, "Fray Benito de la Sierra's Account of the Hezeta Expedition to the Northwest Coast in 1775," California Historical Society Quarterly, 9, No. 3 (1930), Pp. 201-242; Fray Miguel de la Campa Cos, A Journal of Exploration Northward along the coast from Monterey in the year 1775, ed. John Galvin; Juan Francisco de la Bodega Y Quadra, "First voyage to lat. $58^{\circ}$... 1775," TS, trans. G. F. Barwick; and Bruno de Hezeta, "Diario •. 1775," MS.

${ }^{24}$ Extracts (in English trans,) from the 1775 diaries kept by Hezeta, Bodega y Quadra, Pérez, Mourelle, and Campa Cos of the events at Trinidad Harbor are in Robert F. Heizer and John E. Mills, The Four Ages of Tsurai, trans. Donald C. Cutter, pp. 19-56. Sierra's account of the Trinidad sojourn is in Wagner, "Fray Benito de la Sierra's Account - 1775," California Historical Society Quarterly, 9, No. 3 (1930), $\mathrm{PP} \cdot 217-223$.

1775 (author's trans.).

$$
\text { 25 Hezeta, "Diario • • 1775," entry for June 18, }
$$

26 photograph of an iron "sword" archaeologically recovered from the Tsurai village at Trinidad Harbor is in Heizer and Mills, The Four Aqes of Tsurai, p. 86, pl. 2-k. It appears to be of aboriginal design and manufacture, and it likely was one of the objects described by Hezeta as a "knife" (cuchillo).

27 Official accounts of Cook's 1778 visit to northwestern North America are in J. C. Beaglehole, ed., The Journals of Captain James Cook on his Voyages of Discov- 
ery, III, pt. 1, 289-472, and III, pt. 2, 1088-1150, 13231333, 1393-1455. Cook realized that Northwest Coast fur resources had major commercial possibilities; "but," as he noted, "unless a northern passage is found it seems rather too remote for Great Britain to receive any emolument from it" (ibid., III, pt. 2, 371). Some of his sailors, however, upon discovering the high value placed on sea otter pelts by the Chinese in Canton ("50 to 70 dollars a skin") concluded that no such northern passage was needed. Two members of the Resolution's crew stole her "great cutter" and vanished, presumably, as James King (then captain of the Discovery) wrote, "seduced by the prevailing notion of making a fortune, by returning to the fur islands" (ibid., III, pt. 1, 714, n. 1).

28 A list of the fur trading vessels visiting the Northwest Coast in the 18 th century (excluding Russian ships) is in Fredrick $W$. Howay, "A List of Trading Vessels in the Maritime Fur Trade," Transactions of the Royal Society of Canada, 3rd ser., 24, sec. $2(1930), p p \cdot 111-134$; and 25 , sec. $2(1931), \mathrm{pP} \cdot 117-132$. Four French ships are also known to have engaged in the fur trade, although one, L'Emilie, apparently was captained by an American and sailed under United States colors (ibid., 3rd ser., 24, sec. 2, PP. 128-129). See also the Appendix of this study.

${ }^{29}$ Beaglehole, ed., The Journal of Captain James Cook, II , pt. 1, 321 .

30 Ibid., III, pt. 1, 321.

${ }^{31}$ The official account of La Pérouse's 1786 visit to the northwestern coast of America is in Jean F. G. de La Pérouse, A Voyage Round the World Performed in the Years $1785,178 \overline{6}, 1787$, and 1788, I, 354-435.

$$
\begin{aligned}
& 32 \text { Ibid., I, 369-370. } \\
& 33 \text { Ibid., I, } 370 . \\
& 34 \text { Ibid., I, } 407 .
\end{aligned}
$$




\section{RUSSIAN VOYAGES}

The earliest documented contacts between Europeans and natives of northwestern North America occurred in the region stretching from the Bering Sea along the Alaskan coast and among the Aleutian Islands, southward to the collection of islands in Alaska's panhandle known as the Alexander Archipelago. This vast region, once called Russian America, was discovered and first explored by Russian navigators in the first half of the 18th century. Earlier voyages, such as that of Semen Dezhnev (1648), probably brought Russian ships to the very edge of Alaskan waters in the mid17th century. Dezhnev's voyage, once vehemently disputed, now is generally conceded to have established the existence of the strait separating Asia and North America threequarters of a century before Bering's first Kamchatka expedition (1725-1730) accomplished the same same feat somewhat less conclusively. 1

While Mikhail Guozdev's venture to cross Bering Strait in 1732 appears to have involved the first documented instance of a meeting between Russian navigators and North American natives, 2 its ethnographic value is limited and no exchange of goods is known to have occurred. By contrast, 
the expedition led jointly by Vitus Bering and Aleksei Chirikov in 1741 to seek the bolshaya zemlya by sailing east from Kamchatka produced important information about native inhabitants and engaged in limited exchanges with them. Since the vessel under Bering's command, the Sv. Petr, became separated early in the voyage from her consort, the Sv. Pavel captained by Chirikov, the events of the expedition are essentially those of two separate voyages and will be so treated here.

The first landings made by the su. Petr occurred at Wingham and Kayak islands July 20 (0.5.), 1741, just east of the Copper River estuary in southern Alaska. Two boats were sent ashore. One, under the command of Lieutenant Sofron Khitrov, explored Wingham Island to locate a suitable anchorage, while the second with Georg Steller aboard went to Kayak Island to obtain water. ${ }^{3}$ The ship's second officer, Lieutenant Sven Waxel, in describing these landings in his official report to the Russian Admiralty College, observed that

[Khitrov] also reported that on that island [Wingham] he came across a hut built of hewn boards and that there were indications that people occupied the hut shortly before our coming. He brought to show us a wooden basket, a shovel, also a stone which had on it many marks of copper. The Adjunct [naturalist Georg] Steller, who went in the small boat to the island of St. Elias [Kayak], found there an earthen hut - • we saw also human footprints on the sand and a fireplace. It was evident that on seeing us the people ran into the woods to hide or that their homes are on the mainland and they visit this island to catch fish and hunt sea animals. In order to show his good 
will to the native people the Captain Commander [Bering] sent to the hut a number of presents-$16 \frac{1}{2}$ arshins [c. $12 \mathrm{~m} \cdot$ ] of green-colored goods, 2 iron knives, 20 Chinese strings of beads, 2 iron smoking pipes, all of which were left there. ${ }^{4}$

Steller's version of these events differs somewhat from waxel's account in that he asserts that "an iron kettle, a pound of tobacco, a Chinese pipe, and a piece of Chinese silk were sent to the cellar." 5 He also complains that some knives or hatchets should have been left instead of the tobacco and pipe, so it is not entirely clear what articles were in fact placed ashore. 6 Nevertheless, Steller corraborates Waxel's mention of the stone with copper marks. They obtained, the naturalist wrote, "a stone which perhaps, for lack of something better, served as a whetstone, on which were seen streaks of copper, as if the savages, like the ancient Siberian tribes, possessed cutting tools of copper." 7 No direct contact with natives occurred during these landings.

The Sv. Petr left the vicinity of Kayak Island July 21 (0.5.), steering to the southwest. Six weeks later on August $29(0.5$.$) , the Shumagin Islands were sighted off$ the southern coast of the Alaska Peninsula (about $1,100 \mathrm{~km}$. southwest of Kayak Island) and a party was again landed to obtain water. On August 30 (0.5.), while Khitrov was ashore, two natives (probably Aleuts) unexpectedly appeared near the anchored Sv. Petr in skin-covered boats (baidarkas) with whom the Russians engaged in a brief exchange. Waxel 
lists among the articles supplied them: "red (Chinese) silk, mirrors, iron pipes for smoking Chinese tobacco (called shar), and several copper bells." 8 steller also mentions glass beads. 9 Somewhat later, Bering ordered a second party ashore under Lieutenant Waxel's command which pursued further contact with the natives. A cup of "Russian liquor" was offered them, but not surprisingly its recipients "immediately spat it out."10 An iron kettle and some needles, later traded to other visitors at the ship, completed the articles distributed, according to Waxel's account. 11

It was in recording his ethnographic impressions of these people that Steller noticed they already possessed iron knives. He had hoped to buy one of two such knives with "three or more of ours, of which our stores had plenty, because it was very important and perhaps marks might be found on them from which it might be possible to conclude with what nation these islanders had communication . . "12 The knife unfortunately was not purchased, and Steller was left to conjecture about the possible sources from which such objects had been obtained. 13 The Sv. Petr made no further contacts with North American natives after she left the Shumagin Islands. She was wrecked while attempting to anchor at an island (called Bering Island today) some $250 \mathrm{~km}$. off the coast of Kamchatka. Bering and twenty members of the crew perished there; the remaining survivors 
(among whom was Steller) were able to construct a small vessel in which they returned to Avacha Bay. On board the Sv. Pavel, sailing a separate track, Chirikov discovered land on July $15(0.5$.$) in the vicinity$ of Cape Addington, roughly $100 \mathrm{~km}$. north of Dixon Entrance. They sailed northward about $300 \mathrm{~km}$. along the Alexander Archipelago until July $18(0.5)$ when a boat was sent ashore at Lisianski Strait, between Yakobi and Chichagof islands. The boat failed to return, as did a second one sent out five days later to locate the first. Fifteen men and the ship's only means of going ashore were lost in this tragedy. 14

The fate of Chirikov's two shore parties has remained a mystery, 15 but the trade articles they carried ashore were recorded in some detail. Chirikov's instructions to Avraam Dementiev, commander of the first boat, are explicit:

If with God's help you get ashore, lookabout for human beings, if you find them, be gentle with them and present them with a few smali presents with which the ensign Choglokov will provide you, namely a copper and an iron kettle, two hundred beads, three packages of Chinese tobacco, one piece of nankeen, one piece of damask, five rattles, and a paper of needles. From me you will receive ten-rouble pieces which you may distribute among the inhabitants as you think best. 16

It is also known from the ship's journal that Dementiev was equipped with a "hand compass, a small lead, two empty water casks, a grapnel, and a cable. $n^{17}$ whether any of these articles fell into native hands (probably Tlingit) is diffi- 
cult to say, but that possibility cannot be entirely excluded.

The Sv. Pavel next proceeded westward across the Gulf of Alaska, unable to make any further landings because of the loss of her two boats. On September 9 (0.5.), however, the ship nearly went aground in fog at Adak Island in the Andreanof group of the Aleutian chain, resulting in an unintended anchorage close to shore and an unexpected encounter with natives. After the fog lifted, according to the ship's journal, "we caught sight of two men walking through the grass across the hills. - . It was evident that they had caught sight of us and came a little nearer so as to have a good look at the ship."18 Before long, seven of these natives cautiously approached the Sv. Pavel in their skin-covered boats, whereupon, in the words of the ship's log, the Russians

tried to convince them that they had nothing to fear from us. We pressed our hands to our hearts as a sign that we would receive them in a friendly manner. To convince them still more I threw them a Chinese cup as a mark of friendship. One of the men picked it up and after examining it made a gesture as if to indicate that he had no use for it. He was about to throw it back to the ship when we bowed and motioneg for him to keep it, but he threw it in the water.

An attempt to interest the natives in two pieces of damask tied to a board met with similar disinterest. The order was then given to break out and display the remaining trade items they carried: "small boxes, small bells, needles, 
Chinese tobacco, pipes." 20 But it was only after the Russians convinced the natives through signs that they were out of drinking water and needed their help to resupply that the natives came alongside the ship. The trade items mentioned above were distributed, but the natives received them "rather indifferently as if not knowing what to do with them." 21 Everything changed abruptly, however, when

I [Chirikov] mentioned that a knife should be given them, and when they saw it they were over joyed and seized it from one another and with great eagerness begged for more - . We gave them a small barrel in which to bring us water from shore.. - but they would not take the barrel and showed us that they had bladders for that purpose. Three of them paddled towards the beach and returned with water. When they came alongside one of them held up a bladder and indicated that he wished to have a knife in payment. This was given him; but instead of handing over the bladder, he passed it to the second man, who also demanded a knife. When he got it he passed the bladder to the third man, who equally insisted on a knife. 22

Intrigued by the natives' curious hats, "made of thin birch boards, which are decorated with various colors and feathers - . and small ivory statues," the Russians purchased one in exchange for a "dull axe, which they received gladly."23 A copper kettle was offered "as a mark of friendship, which they kept for a little while and then handed back." 24 In the process of extricating the Sv. Pavel from this precarious anchorage one of the ship's an-: chors was lost, 25 but it is unlikely it was retrieved by the natives. Next day, September 10 (0.S.), the Sv. Pavel left Adak, and no further native contacts were made during 
the rest of the voyage.

Russians began retracing the tracks of the Sv. Petr and Sv. Pavel within two years of the return of the 1741 expedition. The men of the Sv. Petr, before reaching homeport, had discovered two uninhabited islands off the Kamchatkan coast which would become the jumping-off place for the penetration of the Aleutian chain. These were the Commander Islands, consisting of Bering Island where the Sv. Petr was wrecked, 26 and nearby Copper Island, so named because of the presence there of copper deposits. 27 Two Russian visits were made to the Commander Islands between 1743 and 1746,28 followed by a long succession of ventures that progressively pushed farther eastward into the Aleutians. The purpose of these voyages was primarily to secure furs, and in so doing trade articles began flowing into native hands with some degree of regularity. Records of these ventures, while more fragmentary than those of the 1741 expedition, shed important light on the materials being traded to the natives as well as testimony about their prior knowledge of European or Asian cultural materials. In 1745, the vessel Eudokim, 29 commanded by Mikhail Nevodchikov, first reached the most westerly islands of the Aleutian chain, collectively called the Near Islands. 30 The trade articles distributed among the natives of these islands by the Nevodchikov expedition included the same materials previously given out by Bering and Chirikov: 
needles, tobacco, Chinese pipes, and cloth. A new item, thimbles, also makes its appearance. 31

In the course of the Russians' winter-long stay, hostilities arose between them and the natives whichapparently led to considerable bloodshed. At least 15 natives are said to have been killed by gunfire in one incident. This event, tragic as it was, ironically revealed important information relevant to this inquiry. One of the Cossacks, a certain Shekurdin, who witnessed the slayings and was shocked at these cruel proceedings, retired unperceived to the ship, and brought an account of all that had passed. Tsiuprov [one of the owners], instead of punishing these cruelties as they deserved, was secretly pleased with them; for he himself was affronted at the islanders for having refused to give him an iron bolt, which he saw in their possession. He had, in consequence of their refusal, committed several acts of hostilities against them. 32

The origin of this iron bolt is uncertain, although it could have come from the remains of Bering's ship, the Sv. Petr, left three years earlier on Bering Island approximately $500 \mathrm{~km}$. to the west. How it might have been transported over that distance is an equally speculative matter, but there is no reason to suppose it an impossibility. 33

The Nevodchikov voyage and its successors in the 1740 s and 1750 s were undertakings of promyshlenniki whose activities were not always recorded in the same detail as government-financed exploring expeditions like the BeringChirikov voyage in 1741. At first they hunted fur-bearing 
animals themselves or bartered with the Aleutian natives, but after about 1748 they turned increasingly to imposing tribute payment or iasak on the natives to secure furs. 34 The materials used in trade are only infrequently mentioned in the accounts of Russian voyages to the Aleutians after 1745, which may have been because trade was not the primary means of obtaining furs or simply inattention to such details. Whatever the case, we learn only sketchy details such as in 1753-1754 "toys were distributed among the savages" of one of the Fox Islands at the eastern end of the Aleutian chain. 35 In 1757, a chief or toion on Attu Island was persuaded to pay tribute in exchange for "a copper kettle, a fur and cloth coat, a pair of breeches, stockings, and boots." 36

of perhaps greater interest are references to European or Asian materials that were found on the Aleutian Islands or among its natives. In August, 1754, the vessel Nikolai commanded by a Cossack named Kodian Durnev reached the Near Islands, remaining there collecting furs until sometime in 1757. During this period, he and a tributecollector named sila Shevyrin reportedly "found upon the island [Attu] three round copper plates, with some letters engraved upon them, and ornamented with foliage, which the waves had cast upon the shore." 37 This description sug-. gests these objects may have been coat buttons that had reached the island as part of drifting wreckage or possi- 
bly with a coat traded to the natives (such as the one mentioned in 1757.) $)^{38}$ The same expedition that in 17531754 reportedly distributed toys somewhere in the Fox Islands observed that the natives there "are all provided with stone knives, and a few of them possess iron ones." 39 But such iron knives evidently were scarce, for five years later, Dmitrii Pankov, commander of the vessel vladimir, reported that "the inhabitants [of the Fox Islands] had no iron." 40

In 1761, a group of islands was discovered between the Near and Fox islands by an expedition commanded by Andrean Tolstykh. These islands, the Andreanofs, 41 and their inhabitants were described by Maxim Lavarov, a Cossack who sailed with the expedition. There is nothing in his account to suggest the natives possessed at that time metal weapons or other non-indigenous materials, which is noteworthy because it was one of these islands (Adak) that Chirikov visited twenty years earlier, distributing knives and other trade items among its inhabitants. As to Tolstykh's trading activities among these islanders in 1761, Lavarov says only that "some toys and other trifles" were traded to Andreanof Island toions. 42

As Russian ships began to converge on the Aleutians in increasing numbers native resentment of the promyshlenniki and their demands for iasak reached explosive proportions. In 1763, five ships 43 were operating in the fox 
Islands when the natives of Unalaska, Umnak, and Unimak launched coordinated assaults on the Russians that saw four of these ships destroyed and all but a handful of their crewmen slain. 44 Accounts of these events make it plain that a substantial quantity and variety of Russian gear fell into native hands in the course of the uprising. When the only vessel that escaped destruction, the Andreian I Natalia, stopped at Umnak Island in July, 1764, her commander, Stepan Glotov, "discovered the remains of a burnt vessel [Denis Medvedev's Ioann], some prayer books, images, etc.; all the iron work and cordage were carried off." 45 Shortly after locating the burnt and stripped ship's hulk, he encountered some natives who beckoned him to come ashore and barter; but "having sufficient cause to distrust the savages, [Glotov] refused - . upon this they [the natives] immediatley landed, and shot from the shore with fire-arms, but without doing any execution." 46 Thus, even firearms had been obtained (and, in this case at least, put to use) by the Aleuts. The commander of the ill-fated Troitsa, Ivan Korovin, in describing the Unalaska and Umnak natives at the time of the uprising, also observed the change that easy access to iron was having on Aleut weaponry:

Their weapons are bows and arrows, lances and darts, which they throw like the Greenlanders - - by means of a little hand-board. . These darts as well as the lances were formerly tipped with bone, but at present [c. 1763] the points are commonly made of the iron which they procure from the Russians, and out of which they ingeniously form little hatchets and two- 
edged knives. They shape the iron by rubbing it between two stones, and whetting it frequently with sea-water. 47

Glotov and the men of the Andreian i Natalia seem to have escaped the brunt of the uprising, because during its height they had left the fox Islands to seek land farther eastward. There they discovered Kodiak Island, about 250 $\mathrm{km}$. to the east of Unimak, encountering natives differing "considerably in dress and language from the inhabitants of the other Fox Islands." 48 These numerous people, calling themselves Koniagas, were at first cool to Russian overtures and entered into trade only reluctantly. Glotov reported no iron weapons among them. 49

The Russians wasted no time in reasserting their authority over the rebellious Aleuts. In September, 1764, Ivan Soloviev anchored the Petr i Pavel off Umnak Island to find out more about what had happened the previous year, with a mind to taking retaliatory measures to prevent future uprisings. The extent of Soloviev's reprisals may never be known exactly, but they clearly cost the lives of many Aleuts. 50 Contemporary accounts of these events mention, in addition to the toll in human life, the recovery of various items taken by the natives in the uprising, such as muskets, kettles, anchors, and miscellaneous tackle. 51 There is also further confirmation that the natives were capable of fashioning weapons from the materials they had captured, for in one clash at Unalaska the Aleuts were said 
to have been "armed with lances, made with the iron of the plundered vessels." 52

In 1768, the first government-financed Russian expedition since the Bering-Chirikov voyage of 1741 set out under a veil of secrecy to confirm and chart the discoveries made by the promyshlenniki in the Aleutians. The expedition included two ships, the galiot ${ }^{53}$ Sv. Ekaterina commanded by Captain-Lieutenant Petr Krenitsyn, and the hooker 54 Sv. Pavel under Lieutenant Mikhail Levashov. They became separated in fog somewhere in the Fox Islands in September, 1768, and thus spent the winter in separate 10cations, Krenitsyn on Unimak Island and Levashov at Unalaska. 55 While the expedition failed to reach Kodiak Island and charted only the easternmost group of the Aleutians, the ethnographic data it brought back of the Fox Island inhabitants are of considerable importance. Writing of the people he spent the winter among, Levashov observed:

There are upwards of a thousand inhabitants on Unalaska, and they say that it was formerly much more populous. They have suffered greatly by their disputes with the Russians, and by a famine in the year 1762; but most of all from a change in their way of life. No longer contented with their original simplicity, they long for Russian luxuries: in order therefore to obtain a few delicacies, which are presently consumed, they dedicate the greatest part of their time to hunting, for the purpose of procuring furs for the Russians. 56

Among the "luxuries" supplied the natives, Levashov lists beads, false pearls, goat's wool, copper kettles, and hatchets. 57 While he and Krenitsyn are silent about native iron 
working and metallic weapons, an illustration of Aleut artifacts attributed to Levashov appears to include metallic implements. 58

Following the Krenitsyn-Levashov expedition, promyshlenniki regularly continued their visits to the Aleutian Islands, and in the 1770 s they began appearing with some frequency as far eastward as Kodiak Island. Peter Simon Pallas, a German-born member of the St. Petersburg Academy of Sciences, traveled extensively in Siberia during this period and collected journals and oral accounts from the men returning from these voyages. These accounts shed considerable light on the nature of Russian fur gathering activities in the 1770 s and the eastward extent of their penetration. 59

In August, 1771, Ivan Soloviev, in command of the Sv. Pavel, reached the Sanak Islands, a group of small, bleak, yet inhabited islands lying some $30 \mathrm{~km}$. southeast of Unimak Island. Their inhabitants, who were frightened "upon the arrival of the ship because they had never seen such people,"60 had all taken refuge on one of the two smaller, rocky, and nearly inaccessible islands southeast of the main island. The Russians approached the natives seeking to gain their confidence with offerings of "glass beads and other trifles." 61 In an abstract of Soloviev's diary, Pallas wrote of this encounter:

These islanders were 51 men strong and had five 
toyons among them. Each had a small leather bidar, in which only one man could sit; but they also had five large bidars. In these boats they row with all their belongings from one island to another. Among these islanders the Russians saw various pieces of Russian workmanship, such as a copper kettle and an iron knife. They said that they had obtained these articles from Alasksha [probably meaning the Alaska Peninsula]. They also declared that in the vicinity of their island there were only a few sea otters [batri62], which never came on land. The Russians stayed one night with these islanders, who voluntarily gave hostages and then returned to their island.63

This indicates the ease with which the natives traveled between islands, and perhaps more importantly it shows that Russian-made articles moved through native trade channels in advance of face-to-face contacts with the islanders.

Soloviev spent nearly three years hunting furs in the Sanak Islands and along the Alaska Peninsula near Deer Island. In time the natives seem to have grown resentful of the Russians' activities, and their hunting parties were threatened or actually attacked on several occasions. In at least one instance some of the Russians' supplies fell into native hands. 64 Soloviev returned to Unalaska and the Fox Islands on July 24 (0.5.), 1774, where he decided to spend the winter. With the Sv. Pavel anchored in a harbor somewhere on Unalaska Island, hunting parties were dispatched that winter to Umnak Island on the west, and as far east as Tigalda Island, among the easternmost of the Fox Islands. Different receptions awaited Soloviev's men in these two areas. The party sent to Umnak readily obtained 
hostages and the natives' cooperation. Soloviev's earlier efforts at "pacification" on this island had evidently been successful, for as Pallas' abstract explains:

The islanders were rewarded with glass beads and other articles. The toyons allowed the crews to hunt on their islands wherever they wished, and were willing to help them in all ways and to supply them with dried fish [yukola] as well as fresh. They were also willing to pay tribute. In return they asked Soloviev to instruct the hunting parties to give traps to the islanders on all the islands to which they went. After these promises Soloviev gave them hatchets and knives as he always did when the islanders brought tribute. 65

But the party sent eastward to Akutan and Tigalda islands was attacked on three occasions, November 22 (0.S.) and December $10\left(0 . S_{.}\right), 1774$, and January $B(0.5),$.1775 , in what apparently became a general native uprising on these two islands. According to Pallas, 15 natives lost their lives in the last of these frays. 66 when Soloviev departed in the spring of 1775, the peace that settled over the eastern Fox Islands must have been grudging and uneasy.

Pallas obtained documentation of another voyage to Alaskan waters during the 1770 s in which Kodiak Island was reached. This was the voyage of the Sv. Mikhail under the command of peredovshchik 67 Dmitrii Bragin, and with apprentice pilot Dmitrii Polutov steering their course. ${ }^{68}$ Bragin prepared an abstract of the journal he had kept during the voyage at Pallas' request. This account says the Sv. Mikhail reached Unalaska Island on September 7 (0.5.), 1774 and anchored on the north side in the same "spacious and 
secure harbor in which Captain-Lieutenant Levashov had formerly anchored."69 Hunting parties were dispatched from this anchorage to many of the Fox Islands, and "wo carried on our hunting," relates Bragin, "without hinderance or mishap, except that at the end of 1775 eleven of the crew, Russians and Yakut, died of scurvy." 70

Late in the spring of 1776, the Sv. Mikhail sailed east for Kodiak Island, which she reached on June 15 (0.5.). Their purpose was to reconnoiter the island for its furhunting potential and establish contact with its natives. On July $4(0.5$.$) , they came in sight of some 40$ islanders who were extremely wary of their Russian visitors. Bragin described the encounter: All appeared armed with shields [kuyaki] lances, and us, ten of us approached them with an interpreter, greeting them in a friendly way, and held out little gifts of enamel and glass beads. But they were un- moved by our invitation, and after some consultation they hastily snatched the proffered gifts from our hands and ran away... -
These not very advantageous prospects brought us to the conclusion to leave this island at once and sail back to Unalaska, where we arrived on the 25 th $[(0.5)$. of July, 1776].71

They remained in the Aleutians hunting furs as they moved westward until the end of July, 1777, when they returned to Kamchatka. 72

A third voyage in the 1770 s about which Pallas obtained documentation was that of the ship Sv. Vladimir, commanded by Potop Zaikov. ${ }^{73}$ After threading their way eastward 
through the Aleutians, the Sv. Vladimir arrived off Unimak Island August 17 (0.S.), 1775, where she entered Isanotski Strait separating that island from the Alaska Peninsula. There Zaikov cast anchor in a bay that he believed was the same one at which Krenitsyn had wintered. The Russians remained at this anchorage nearly three years, during which time they sent out hunting parties ranging widely over the islands to the east along the Alaska Peninsula. Zaikov's hunters must have reached as far east as the Shumagin Islands sometime between 1776 and 1778, for when James Cook's expedition passed near Unga Island (one of the Shumagins) in June, 1778, they saw among the natives iasak receipts in which mention of these years was noted. 74 Based on Zaikov's account, Pallas described the manner in which he dealt with the natives:

Being on friendly terms with the natives of Unimak, they won also the good will of the Aleuts, who live across the strait on the American peninsula Aläska. These people often visited the Russians in their dwellings, and were entertained with the things they liked best. The Russians also gave them Circassian tobacco, glass beads of various colors, copper kettles, shirts, and cat skins. Zaikov won these people completely, and they voluntarily brought tribute. 75

The ships in which Soloviev (1770-1775) and Zaikov (1772-1779) had sailed were both owned by companies in which a certain Tula arms manufacturer named Afanassi Orekhov had been a principal figure. ${ }^{76} \mathrm{He}$ and his associates of the Soloviev voyage also financed an expedition 
to the Fox Islands between 1776 and 1781. Orekhov's name was thus prominent among those who were backing Russian fur gathering ventures in the 1770s. But his prominence was destined to be soon eclipsed by another name, that of Grigorii Ivanovich Shelikhov. This merchant from Rylsk, with his principal associate, Kursk merchant Ivan Golikov, devised a new approach to organizing fur gathering expeditions that would have a profound influence on the expansion of Russian activities into North America.

An agreement concluded at St. Petersburg in 1781 between Shelikhov, Golikov, and the latter's nephew, Captain Mikhail Golikov, established a company that was fundamentally different from those previously created to finance fur gathering expeditions in the Aleutians. "First of all," as Makarova explains, "the agreement stipulated that the company was created not just for one 'voyage,' as was usually the case, but for a period of not less than ten years." 77 secondly, the agreement called for the founding of permanent settlements and forts to save the time and expense of transporting promyshlenniki back and forth through the Aleutians. Shelikhov also believed that groups of resident hunters would be better organized, more efficient, and therefore less costly. 78 In August, 1783, the first three ships of this new enterprise, the galiots Iri Sviatitelia (Three Saints), Mikhail, and Simeon, set out from Okhotsk. Shelikhov and his wife, Nataliia, were 
aboard the Iri Sviatitelia. The expedition cast anchor August $3\left(0.5_{0}\right), 1784$, on the south coast of Kodiak Island at a harbor they named Three Saints Bay. ${ }^{79}$ In this fashion, Russian activities in North America entered into an entirely different phase in which permanent settlements and systematic exploration eastward and southward along the coast would come to prevail.

Meanwhile, in 1783, promyshlenniki of Shelikhov's rivals discovered a large bay on the southern Alaska mainland not far from where Bering had first sent Steller ashore in 1741. 80 This many-lobed, well-protected body of water was called Chugach Bay by the Russians, although it had earlier been named Sandwich Sound by James Cook when he visited it in 1778. Under the name Prince William Sound it would later become a familiar port-of-call for fur traders, and it seems to have been a key location for native trading activities before the arrival of Europeans. Evstrat Delarov, one of the Russians who wintered at Prince William Sound in 1783, described his dealings with the natives there and, in so doing, shed some light on the copper-streaked stone that Steller had seen near there 42 years earlier:

I offered them shirts and clothes, which they did not seem to want; and tobacco they rejected. They behaved in a very friendly manner. We were quite off our guard, and ate, drank, and slept together in the greatest harmony. They informed us, that two ships [probably Cook's Discovery and Resolution] had been there some years back, and gave them great store of beads and other articles. By their description, these vessels must have been English. They had 
knives and copper kettles, which they obtain up a great river [Copper River?] about 14 days journey against the stream, where the natives were numerous, and had great quantities of copper. 81

Shelikhov also dispatched expeditions from his base at Three Saints Bay on Kodiak Island to reconnoiter the mainland to the eastward. "On May $2\left[\left(0 . S_{.}\right), 1785\right]$," he wrote, "I sent 52 Russian workers, 11 fox Island Aleuts, and 110 Koniags in four baidarkas... In order to make contact with persons inhabiting the islands located along the American mainland as far as Kenai and Chugach bays [Cook Inlet and Prince William Sound], ascertaining benefits and describing everything important." 82 The party returned in August, but without accomplishing all that Shelikhov had hoped for. A second expedition was thus readied the following year, of which Shelikhov wrote:

On March $7\left[\left(0 . S_{.}\right), 1786\right]$, I sent out five Russians to the Cape of St. Elias [on Kayak Island] to complete further descriptions, which had not been finished the previous year, and to build on that cape a stronghold which will holp in this undertaking. with an understanding that it be done with the agresment of the local inhabitants. They were to proceed as far as the $47 \mathrm{th}$ degree of latitude, and were to be accompanied by a thousand Koniags from Kadiak [Kodiak] and other islands and $70 \mathrm{Fox}$ Island Aleuts, who volunteered for that service. I ordered them to place crosses along the shores and to bury pieces of pottery in the ground. 83

Shelikhov's attention, however, was temporarily diverted from exploration when a native uprising erupted on the Kenai Peninsula in the spring of 1786, which apperently had its origins with a toion on Shuyak Island (one of the 
small islands lying northeast of Kodiak, opposite the Kenai Peninsula). In quelling this rebellion, Shelikhov established forts on Afognak Island (between Kodiak and Shuyak islands) and on the Kenai Peninsula. 84 The stronghold he ordered constructed at Cape St. Elias was also apparently completed, but it is uncertain how far eastward of that cape Shelikhov's men managed to place crosses and bury pottery, as they had been instructed. While it seems doubtful they could have reached the 47 th parallel (on the central Washington coast), they may well have gone as far as Yakutat Bay or even beyond to some point in the Alexander Archipelago.

On May 22 (0.5.), 1786, Shelikhov departed Kodiak to return to Siberia, leaving the Three Saints Bay outpost in the hands of K. A. Samoilov, a merchant from Eniseisk. In the following year, Evstrat Delarov, the same person who had wintered at Prince William Sound in 1783, was employed by Shelikhov to take charge of the company's Kodiak establishment and supervise the exploration and fur-gathering activities centered there.

Concern over reports of foreign vessels in the vicinity of Kodiak now also led the Russians to redouble their efforts to strengthen their sovereign claims on the American mainland. Secret instructions, over the signature of Lieutenant-General Ivan Iakobi, governor in Irkutsk, were issued on June $21\left(0 . S_{.}\right), 1787,85$ to insure that markers sup- 
porting Russian claims were placed at appropriate locations in Alaska. These instructions, addressed to "the representative of Shelikhov, Samoilov and Delarov," stated:

When you receive a package containing fifteen insignia of the Russian Empire and ten steel plates on which there is a copper cross and copper letters saying THIS LAND BELONGS TO THE RUSSIAN EMPIRE, immediately try to place these insignia on terra firma in that part of western America known as Alaska. It is desirable that the insignia be erected in the same location where an English ship anchored in the year 1784 and engaged in a rich and profitable trade. To the best of our knowledge that location is below 50040 (latitude). 86

In compliance with Iakobi's intentions, Delarov dispatched the Iri Sviatitelia, under Gerassim Izmailov and Dmitrii Bocharov, in the spring of 1788 to leave these plates at a variety of locations along the Alaskan coast. They visited Prince William Sound, delivering one of the plates to "one of the leading natives of Suklia [Montague] Island." 87 They next

proceeded to what the natives called Yakutat Bay (known to the Russians as Bering Bay), and there dropped anchor. The toion of this region was also entrusted with a crest and in addition ho requested, and enthusiastically received, a portrait of Grand Duke Paul Petrovich, heir to the throns. After visiting several other places along the American coast, including L'tua [Lituya] Bay, the ship had to return in July to Kad'iak [Kodiak] Jsland, owing to the large number of sick on board. 88

A third government-financed Russian expedition visited Alaskan waters in 1790 with orders to explore the vicinity of Kodiak Island and Prince William Sound. 89 It was commanded by an Englishman named Joseph Billings, who 
had been there previously with Cook's expedition in 1778. In July 1790, two members of the Billings expedition, Gavriil Sarychev and Martin Sauer, explored the maze of inlets within Prince William Sound, where they encountered natives (probably Chugach Eskimos) on several occasions. Since one of the purposes of the Billings expedition was to ascertain the extent of foreign penetration in Alaska, Sauer and Sarychev inquired at every opportunity about other ships that had visited the sound. One informant, an old man described as "very good natured and intelligent," told them through an interpreter about previous visits of "two and three masted ships," which Sauer assumed were Spanish.90 This informant is even said to have remembered and described the arrival of the first European ship, apparently Bering's Sv. Petr in 1741 at Kayak Island just east of Prince William Sound. 91

Saver also learned from the natives that

a very considerable river - - falls into the sea a day's journey north of our anchorage [at the entrance to Prince William Sound near Cape Hinchinbrook] up which the natives travel 14 days to the residence of a different nation, the people of which supply them with knives, copper kettles, and instruments, and make their canoes. That these people trade with others farther inland, and obtain from them knives and other articles; but that this nation never go farther than 14 days' journey. That the articles of their trade are, the skins of sea-lions, for boats; for points to arrows; and that these were a very powerful and warlike people. 92

The importance of this nearby river, most likely the Copper 
River, 93 as an artery for native commerce and a source of copper items was thus again noted, corroborating Delarov's account of seven years earlier, even to the 14-day duration $^{94}$ of the natives' upriver trading journey. It is of some importance to mention that not only the Chugach Eskimos, with whom Delarov, Sarychev, and Sauer apparently spoke had access to this trade artery, but that the Eyak Indians at the river's mouth were also participants. The Eyaks, although culturally distinct from both Eskimos and the Tlingit, had trading connections and some cultural ties with the latter; and thus through the Eyak, Northwest Coast Indians also had indirect access to the Copper River trade. 95

When Izmailov and Bocharov reached Yakutat Bay and pushed southward at least as far as Lituya Bay in 1788, it meant that the promyshlenniki were operating in the territory of the Tlingits, or Kolosh as the Russians called them. These were people whose cultural affiliations were solidly with the Northwest Coast Indians instead of the Aleut-Eskimo peoples. Delarov's successor, Aleksandr Baranov, went on to establish permanent Russian settlements at Yakutat in 1795, and then over $350 \mathrm{~km}$. beyond at Sitka in 1799, 96 thus extending the Russian presence at least as far south as latitude $57^{\circ} \mathrm{N}$. At the end of the $18 \mathrm{th}$ century Russian trading influence almost certainly reached farther south, and it had by then clearly become an 
important source of European and Asian materials not only in Alaska but throughout the Northwest Coast. 
${ }^{1}$ See Fisher, Bering's Voyages, Whither and Why, PP. $3-7$.

${ }^{2}$ See pp. 10-11 of this study.

3 Identification of geographic locations visited by the vessels of the second Kamchatka expedition are based on the work of Ellsworth P. Berthof (see Golder, Bering's Voyages, I, 330-348).

${ }^{4}$ Ibid., I, 271-272.

5 Ibid., II, 51. There were frequent disputes between Steller and the naval personnel over a variety of issues in the course of the voyage. He seldom missed an opportunity to criticize their judgment, and his perception of events often differed from their's (see Leonhard Stejneger, Georg Wilhelm Steller, Pp. 257-258).

6 When the vicinity of Kayak Island was visited by the Billings expedition in 1790, a native informant told two of its members, Martin Sauer and Gavriil Sarychev, about recollections of a landing that probably was the one made in 1741. Sauer's account says that they were told that "some glass beads, leaves [tobacco], an iron kettle, and something else" were left (see Martin Sauer, Expedition to the Northern Parts of Russia, p. 193). Sarychev, however, says that only "some knives and beads" were mentioned (see Gavriil Sarychev, Account of a Voyane of Discovery, p. 25). $52-53$.

7 Golder, Bering's Voyages, II, 52; also see n. 99,

$$
\begin{aligned}
& 8^{\text {Ibid., I, }} 274 . \\
& { }^{9} \text { Ibid., I I, } 92 .
\end{aligned}
$$

10 Ibid., I, 274. The liquor probably was vodka (see Stejneger, Georg Wilhelm Steller, P. 297), although Steller refers to it as "brandy" (Golder, Bering's Voyages, II, 94 ).

${ }^{11}$ Ibid., I, 274.

12 Ibid., II, 97.

${ }^{13}$ Steller implies that the knife was not purchased because of his naval colleagues' unwillingness to part with those knives in their own well-stocked supply or because they were unable to understand the importance of obtaining 
one of the native knives (see ibid., II, 97).

14 Accounts of the loss of these men are in the Sv. Pavel's journal (ibid., I, 292-297) and Chirikov's of ficial report (ibid., I, 314-317).

${ }^{15}$ Chirikov was fearful that his men had been killed or captured by natives (ibid., I, 296, 317), but it is just as likely that the treacherous tidal currents of Lisianski Strait claimed his men (ibid., I, 311).

$$
\begin{aligned}
& 16 \text { Ibid., I, 315. } \\
& 17 \text { Ibid., I, } 292 . \\
& 18 \text { Ibid., I, 303. } \\
& { }^{19} \text { Ibid., I, } 304 . \\
& 20_{\text {Ibid., I, 304. }} \text { Ibid., I, 304. } \\
& 22 \text { Ibid., I, } 304-305 . \\
& 23 \text { Ibid., I, } 305 . \text { These hats were eye shades similar }
\end{aligned}
$$
to those described by Cook in 1778 at Unalaska and pictured by that expedition's artist, John Webber (see Beaglehole, The Journals of Captain James Cook, III, pt. 1, 459, n. 2, and pl. 52a).

24 Golder, Bering's Voyages, I, 305.

25 Ibid., I, 305.

26 Bering died there of scurvy December $8\left(0 . S_{.}\right), 1741$, together with twenty others who similarly perished that winter. The Sv. Petr had anchored at this island out of desperation and in the mistaken belief that it was part of the Kamchatka mainland. The vessel was soon beached in a storm, and from its remains a smaller vessel (called a hooker) was constructed, which eventually brought the survivors back to Kamchatka (see ibid., I, 276-280; II, 130-187; and Stejneger, Georg Wilhelm steller, Pp. 311-346, and 368-375).

27 Coxe, Russian Discoveries, P. 107.

${ }^{28}$ The vessel Petr, commanded in 1743-1744 by Emelian Basov and 1745-1746 by . Sannikov, made these voyages (see Makarova, Russians on the Pacific, P. 209). Accounts of these and subsequent voyages to the Aleutians between 1743 
and 1770 are given in Coxe, Russian Discoveries.

${ }^{29}$ This vessel was a shitik, described as "a sort of flatboat, almost keeless, so it could be easily beached, yet remarkably stable. It was built to be poled along, or towed from shore, or sailed, having two masts sparred for single square mainsails" (see Hector Chevigny, Russian America,

${ }^{30}$ These islands are individually called Attu, Agattu, and the Semichi group.

${ }^{31}$ Coxe, Russian Discoveries, pp. 31-32.

32 Ibid., P. 34 .

${ }^{33}$ This iron bolt has been cited as evidence that such objects could be transported as part of drifting wreckage by T. A. Rickard in "The Use of Iron and Copper by the Inians of British Columbia," P. 44. Ocean cuvents tend to move from the Commander Islands toward the Near I slands, which supports the conjecture that the bolt may have come from wreckage derived from the Sv. Petr. The likelihood that Aleutian natives voyaged to the Commander Islands seems slight, since the 1741 expedition found Bering I sland uninhabited with "no signs that people ever lived there" (see Golder, Bering's Voyages, I, 278). Another possibility concerns the fact that several Japanese vessels are known to have been wrecked in the Kamchatka-Aleutian area before 1745 , and wreckage from one of them might have washed ashore in the Near Islands (see C. W. Brooks, "Report of Japanese Vessels Wrecked in the North Pacific Ocean • •." p. 9).

${ }^{34}$ Iasak was explained to the natives as payment to the Tsar for protection, but more often than not it was perceived as "smooth talk intended to get furs out of them for nothing" (see Chevigny, Russian America, p. 37).

${ }^{35}$ Coxe, Russian Discoveries, pp. 50-51. The principal islands of the fox group are Umnak, Unalaska, Akutan, and Unimak.

$$
\begin{aligned}
& 36 \text { Ibid., P. } 55 . \\
& 37 \text { Ibid., P. } 46 .
\end{aligned}
$$

${ }^{38}$ Coat buttons in the mid- or later 18 th century typically consisted of flat copper-alloy disks decorated with engraved designs (see Ivor Nö̈l Hume, Artifacts of Colonial America, pp. 89-90). For examples of such buttons with floral designs found archaeologically in the Northwest Coast area see John Woodward and Herbert K. Beals, "Fur Trade Sym- 
bols: A Glimpse from the Gladstone Graves," Pp. 108-112. ${ }^{39}$ Coxe, Russian Discoveries, pp. 51-52.

40 Ibid., p. 62 .

41 The principal islands of this group are Tanaga, Kanaga, Adak, Great Sitkin, Atka, and Amlia.

${ }^{42}$ Coxe, Russian Discoveries, $p .78$.

43 They were: Ioann, under Denis Medvedev; Zakharii $i$ Elizaveta, under P. Druzhinin; Troitsa, under Ivan Korovin; Andreian i Natalia, under Stepan Glotov; and Nikolai, under L. Nasedkin (see Makarova, Russians on the Pacific, P. 212).

${ }^{44}$ The Ioann, under Medvedev, was apparently attacked on Umnak Island with the loss of her entire crew under circumstances that were never fully known. Drushinin's Zakharii $i$ Elizaveta was lost on Unalaska Island, with only four survivors to tell of the native assault that killed their shipmates. The wreckage of the Troitsa was left strewn on an Umnak Island beach. Twelve members of her crew (including the captain, Korovin) eventually escaped. Wreckage found on Umnak Island in 1765 probably was the remains of the Nikolai, commanded by Nasedkin, but no survivors lived to tell what happened. Only the Andreian i Natalia, under Glotov, managed to escape destruction at native hands. Accounts of the 1763-1764 Aleut uprising are in Coxe, Russian Discoveries, PP. 80-130 and 139-140. Also, see V. N. Berkh, A Chronological History of the Discovery of the Aleutian Is lands, PP. 32-38; and Makarova, Russians on the pacific, P. 212 .

$$
\begin{aligned}
& { }^{45} \text { Coxe, Russian Discoveries, } p \cdot 119 . \\
& 46 \text { Ibid., P. } 120 . \\
& 47 \text { Ibid., P. } 105 .
\end{aligned}
$$

48 Ibid., p. 115. The natives belonged to a branch of the Eskimo people distinct from the Aleuts.

$$
49 \text { Ibid., P. } 116 .
$$

50 The account of Soloviev's voyage in Coxe (pp. 131155 ) indicates that in five separate clashes a total of 70 natives died. G. I. Davydov, a Russian naval officer who visited the Aleutian Islands in 1802 in the service of the Russian-American Company, asserted that "Soloviev . . . killed more than 3,000 Aleuts . . " (Gavriil Ivanovich Davydov, Two Russian Voyages to America, p. 188). But V. N. 
Berkh, writing in 1823, contended "this number is greatly exaggerated. Eyewitnesses told Ivan Savich Lapin that not more than two hundred were killed" (see Berkh, A Chronological History of the Discovery of the Aleutian Islands, PP. $41-42)$.

$$
\begin{aligned}
& 51 \text { Coxe, Russian Discoveries, PP. } 135 \text { and } 139 . \\
& 52 \text { Ibid., P. } 144 \text {. }
\end{aligned}
$$

53 The term "galiot" refers to a two-masted vessel originating in the Mediterranean, with a forward mast taller than the after, a gaff-rigged mainsail, auxiliary jibs forward, an auxiliary gaff-rigged sail aft, and a square fore-topsail (see Björn Landström, Sailing Ships, p. 163). The galiots built at Okhotsk were developed to replace the shitik and thus differed from the Mediterranean galiot in that they were broader of beam, almost keelless, and equiped with long oars that could be operated below the main deck (see Chevigny, Russian America, pp. 162.).

\section{${ }^{54}$ The term "hooker" refers to a relatively small,} two-masted vessel, with square-rigged main and topsails, auxiliary jibs forward, and a lateen sail aft (see Landström, Sailing Ships, p. 162).

55 Makarova, Russians on the Pacific, pp. 148-149. There are two English translations of extracts from the Krenitsyn-Levashov journal to which this writer has had access. One is a version in Coxe ( $P P_{0}$ 251-266) and the second an unpublished translation by $E$. A. P. CrownhartVaughan of material contained in Divin, Russkaia Tikhookeanskaia epopeia, Khabarovsk, 1971, No. 77, Pp. $357-362$.

${ }^{56}$ Coxe, Russian Discoveries, PP. 259-260.

57 Ibid., P. 265.

${ }^{58}$ This illustration is in Davydov, Two Voyages to Russian America, between pp. 150 and 15i, entitled "Aleut man (by Levashov, about 1768)."

${ }^{59}$ The accounts referred to here are in James $R$. Masterson and Helen Brower, eds., Bering's Successors, 1745-1780, Contributions of Peter Simon Pallas to the History of Russian Exploration toward Alaska, pp. 67-92.

60 Ibid., P. 78 .

61 Ibid., pp. 78-79. 
62 Sic. The Russian word for sea otter is bobry.

63 Masterson and Brower, p. 79.

${ }^{64}$ In December, 1771, the Sanak islanders attacked a hunting party killing one of its members. Pallas adds: "The hut in which the hunting party had stored their supplies and all their equipment was destroyed. The islanders threw some of it into the sea and took much of it away with them" (see ibid., p. 80).

65 Ibid., P. 83 .

66 Ibid., P. 84 .

${ }^{67}$ This term, according to Pallas, referred to "an experienced seaman, employed as pilot of a vessel fitted out and as commander of a crew, and already familiar with the character of the islands from several voyages." Pallas rendered the word in German as vormann, equivalent to "foreman" in English (see ibid., p. 67, n. 225).

${ }^{68}$ Makarova, Russians on the Pacific, $p .213$, lists Polutov alone as skipper of this voyage.

69 Masterson and Bower, Bering's Successors, p. 69. Levashov described two bays on the northeast side of the island, Udagha (probably today's Unalaska Bay) and Igunok (Beaver Inlet), but he does not say which one he wintered in (see Coxe, Russian Discoveries, p. 255).

70 Masterson and Bower, p. 71.

71 Ibid., pp. 72-73.

${ }^{72}$ The port from which Bragin's Sv. Mikhail had originally sailed was Okhotsk, which is located on the Siberian coast across the Sea of Okhotsk some $800 \mathrm{~km}$. west of the Kamchatka Peninsula. Bragin had intended to return to Okhotsk, but contrary winds brought him to the mouth of the Kamchatka River instead, where he decided to disembark his cargo (see ibid., p. 76).

73 An abstract of Zaikov's report to the Russian Imperial Academy of Sciences and a map based on manuscript charts by Bragin and Zaikov were published by Pallas in his Neve nordische Beyträge. II (see Masterson and Bower, pp. 85-92, and map between pp. 68-69).

${ }^{74}$ See Beaglehole, The Journals of Captain James Cook, III, pt. 1, 383-384; also see pp. 80-81 of this study. 
75 Masterson and Bower, Bering's Successors, p. 89.

76 Orekhov's associates in the Soloviev expedition (1770-1775) had been two merchants, Vassili Shilkov of Ustyug and Ivan Lapin of Sulikamsk. His partner in Zaikov's voyage (1772-1779) was Egor Peloponisov, a Greek Ukranian merchant (see ibid., pp. 77 and 85; and Makarova, Russians on the Pacific, p. 213).

$$
\begin{aligned}
& { }^{77} \text { Makarova, P. } 122 . \\
& { }^{78} \text { Ibid., P. } 122 . \\
& { }^{79} \text { See P. A. Tikhmenev, A History of the Russian- } \\
& \text { American Company, PP. 12-14. }
\end{aligned}
$$

80 Makarova, Russians on the Pacific, $p, 214$, attributes the discovery of Chugach Bay (Prince william Sound) to an apprentice navigator named Filip Mukhoplev. He was skipper of the vessel Mikhail, owned by Aleksei Kholodilov, apparently the same merchant who financed Bragin's voyage in the same ship (1772-1778). Mukhoplev seems to have wintered there in 1783-1784 with Potop Zaikov, who was then captain of the Aleksandr Nevskii, owned by Afanassei Orekhov and his two associates, Vassili Shilkov and Ivan Lapin. Zaikov, according to V. K. Berkh, Chronological History of the Discovery of the Aleutian Islands, P. 62, learned of this bay from talking with members of the Cook expedition during their stay in Kamchatka in 1779. A third ship, the Aleksei under Evstrat Delarov, also spent the winter of 1783-1784 at Chugach Bay. According to Berkh (p. 62), this ship was owned by Kholodikov, Orekhov, and Panov, although Makarova, Russians on the Pacific, p. 215, lists only the last-named merchant. James Cook explored and charted the sound in 1778, naming it at first for the Earl of Sandwich, although the name was soon thereafter changed to Prince William Sound in honor of George III's son (see Beaglehole, The Journals of Captain James Cook, II I, pt. 1, 356). p. 197 .

${ }^{81}$ Sauer, Expedition to the Northern Parts of Russia,

${ }^{82} \mathrm{G}$. I. Shelikhov, ed. B. P. Polevoi, Rossiiskoqo kuptsa Grigoriia Shelikhova stranstvovania iz Okhotska po Vostochnomu Okeanu k Americkanskim bereqam The Travels of the Russian Merchant Gregorii Shelikhov from okhotsk across the Eastern [Pacific] Ocean to the American shores). Khabarovsk, 1971, pp. 35-61, trans. Basil Dmytryshyn and E. A. P. Crownhart-Vaughan, TS., P. 16. 
${ }^{83}$ Ibid., P. 18.

${ }^{84}$ Besides Shelikhov's account of this uprising (ibid., pp. 18-19), it is also described in Tikhmenev, A History of the Russian-American Company, pp. 16-17. Another account by Under-Surgeon Miron Britukov is in the Library of Congress Golder Collection, Transcripts, Box 3, Russian Archives of the State, Petrograd, 1789, VII, \#2742. In it, Britukov suggests that Shelikhov's methods were excessively brutal.

85 "Secret Instructions from Lieutenant-General Iakobi to the Representative of Shelikhov, Samoilov and Delarov. June $21\left[\left(0 . S_{.}\right)\right], 1787 . "$ TS. in Oregon Historical Society collection, attributed to Tikhmenev, II, Appendix, pp. 2123. The inscription on the plates read in Russian: Zemlia rossiiskano vladeniia, according to Tikhmenev, A History of the Russian-American Company, p. 20.

86 "Secret Instructions from Lieutenant-general Iakobi - ." The English ship referred to may have been James Hanna's brig Harmon (or Sea Otter), which visited Nootka Sound in the summer of 1785. There are no records of an English visit to the Northwest Coast in 1784 (see Howay, "A List of Trading Vessels in the Maritime Fur Trade").

pany, P. 24 .

${ }^{87}$ Tikhmenev, A History of the Russian-American Com${ }^{88}$ Ibid., PP. 24-25.

${ }^{89}$ Accounts of this expedition are in Sauer, Expedition to the Northern Parts of Russia; and Gavriil Sarychev, Account of a Voyage of Discovery to the North-East of siberia, the Frozen Ocean, and the Pacific, pp. 154-161; and Beaglehole, The Journals of captain James Cook, II , pt. 2, 1474 .

90 Sauer, Expedition to the Northern Parts of Russia, p. 193. The assumption that previous European visitors were Spanish was well founded (except in the cases of Bering and Cook). Sarychev, Account of a Voyage of Discovery, II, 24, mentions seeing "on shore - across with a Latin inscription, similar to what is found on catholic crosses." Spanish expeditions visited Prince William Sound in 1779, 1788, and 1790, each time formally taking possession of the land. The cross seen by Sarychev very likely was one left by the Fidalgo expedition in June, 1790, or possibly by the Martínez expedition in May, 1788, both of 
which left crosses bearing Latin inscriptions (see Wagner, Cartography of the Northwest Coast to the year 1800, I, 203 and 221 ).

91 Saver, Expedition to the Northern Parts of Russia, p. 193. Sarychev's description of this incident differs from Sauer's in that he remembered the informant saying "that his father had related to him something of this ship $25{ }^{\circ}$." (see Sarychev, Account of a Voyage of Discovery. II,

92 Sauer, Expedition to the Northern Parts of Russia, pp. 194-196.

${ }^{93}$ The mouth of the Copper River is said to have been discovered in 1783 by a subordinate of Potop Zaikov named Negaiev. He apparently also learned from the natives at the river's mouth (probably Eyak Indians) of its importance in trade (see Frederica De Laguna, Under Mount St. Elias, I, 112 ).

94 Nagaiev heard the journey took 20 days, but that would have been from the river's mouth, a different location than either Delarov or Sauer and Sarychev had been in (see De Laguna, I, 112).

$95 \mathrm{Kaj}$ Birket-Smith and De Laguna, The Eyak Indians of the Copper River Delta, Alaska, pp. 1 $149-150$.

$96 \mathrm{~K}$. T. Khlebnikov, Baranov, Chief Manager of the Russian Colonies in America, pp. 15-31. 


\section{CHAPTER IV}

SPANISH VOYAGES

Spanish exploring vessels first appeared on the Northwest Coast above the 45 th parallel in 1774 with the voyage of the frigate Santiago under Juan Pérez. ${ }^{1}$ This expedition made contact with natives at Parry Passage on the northern extreme of the Queen Charlotte Islands and at Nootka Sound on Vancouver Island. No member of the expedition, however, actually went ashore, and Pérez' failure to bring back charts of the coast he had glimpsed necessitated a second expedition the following year.

Two ships, the Santiano and an escort schooner named Sonora, were thus dispatched from San Blas, Mexico, on March 16, 1775, with orders to perform a more thorough reconnaisance of the coast as high as the 65 th parallel. Bruno de Hezeta, who had replaced Pérez as captain of the Santiago, had overall command of the expedition, and Juan Francisco de la Bodega y Quadra was the Sonora's skipper. After a ten-day layover in June at Trinidad Harbor on the northern California coast, ${ }^{2}$ they proceeded northward until high winds in mid-July forced them to seek shelter on the coast of Washington state. There, early on the morning of 
of July 14, 1775, probably on the exposed cove south of Point Grenville, the first recorded European landing from Kayak Island (Alaska) to Trinidad Harbor (California) occurred. 3 The Spanish exchanged some glass beads for fish with six young natives whom they encountered, but Hezeta remained ashore only long enough to take formal possession. The Sonora, in the meanwhile, was anchored some four or five miles to the north of Point Grenville in the lee of Cape Elizabeth, near the mouth of the Quinault River. Francisco Antonio Mourelle, second officer of the schooner, described how they were visited that morning by several canoes full of Indians:

On the 14th in the morning the sea ebbed so low, that the ridges of rocks appeared along the coast, which prevented us from then sailing, and obliged us to wait for the full of the tide, which was to happen at 12 at noon. During this interval the Indians trafficked with us for various skins of animals, for which they expected some pieces of iron in exchange, which they manifested by putting their hands upon the rudder-irons [4]; our people therefore procured them such, from old cheşts, after which they returned to their village. 5

From these remarks, the natives (probably Quinaults) apparently were sufficiently familiar with iron to ask for it specifically. Bodega's account adds a few details:

On the 14th I awaited high tide to get out. During this time several canoes of Indians came up, so tractable in appearance that they bartered skins with my crew with the utmost gentleness. I gave them beads mirrors and handkerchiefs, for which they endeavoured to repay me with abundance of various fishes and whale flesh. 6

This seemingly friendly exchange turned tragic, how- 
ever, as Bodega describes:

After this reciprocal traffic I sent six men ashore well armed, with the Boatswain [Pedro Santa Ana], to cut wood, timber for a cap which had split, and to replenish the water which we needed: but [while] disembarking for their tasks more than 300 Indians fell upon them by surprise, and as far as I could judge slew them; for in the space of two hours I did not see in the midst of the tumult more than one flash without report - . I also noticed that two of my people started to swim to the ship, but if they were wounded the coldness of the water or excessive loss of blood would prevent them from reaching it, and I am therefore in doubt whether they perished from drowning, or by the hands of the traitors.

How painful such a massacre was to me I leave it to the world to judge.?

These events were soon followed by a canoe-borne assault on the schooner itself, which was, however, repulsed with six or seven natives losing their lives in the attempt. The motives for this attack remain obscure, but one surmise is that the natives were after the iron fittings of the boat. The Santiago and Sonora continued northward, but in a storm off the coast of Vancouver Island they became separated. The Santiago returned alone sailing south along the coast, where Hezeta discovered the mouth of the Columbia River on August 17, 1775. He reached Monterey at the end of August, being later joined there by the Sonora. Both ships eventually returned to San Blas in November. During their separation, from July 30 to October 7, the Sonora proceeded far to the north, becoming the first Spanish ship to explore Alaskan waters. 8

On August 15, 1775, Bodega made landfall within sight 
of the volcanic cone of Mount Edgecomb on Kruzof Island in the Alexander Archipelago. There he entered nearby Sitka Sound (calling it Guadalupe) and anchored overnight. In returning to the outer coast, the Sonora encountered two canoes, each with two men and two women, but no contact was made with them. Continuing northward along the west coast of Kruzof Island, Bodega found a harbor protected by a chain of small islands where he anchored on August 18. He named it Puerto de los Remedios, probably the same small inlet at $57^{\circ} 18^{\prime} \mathrm{N}$. latitude that is today called Sea Lion Cove just south of the entrance to Salisbury Sound.

Bodega's Los Remedios anchorage had an inviting sand beach, a small river, and, as he explains, "an Indian habitation close by, not badly built, with a breast-work of palisade fronting the river." 9 Its inhabitants numbered about 20 and they were almost certainly Tlingits; it is unlikely that they had seen Europeans before. 10 Francisco Mourelle, the Sonora's second officer, describes the landing:

Five of us landed about noon, when, having posted ourselves in the safest place we could fix upon, we planted the cross with all proper devotion, cutting another on a rock, and displaying the Spanish colours. - .

When we had thus taken possession of the country we advanced quite to the bank of the river, in order to fix upon the most convenient place for water. . . Having fixed upon the proper spot, we now returned to the ship, the Indians having not come forth from their parapet. 
We soon however perceived them approach the place where we had fixed the cross, which they took away, and fixed it on the front of their house. 11

On the following day, when the Spanish returned to the river for water, the natives came out displaying "a kind of pennon of a white sheet on a long pole... and spoke at great length, but not a word we could understand."12 The natives insisted on payment for the water, which led Bodega to offer them "beads, handkerchiefs, and mirrors, $" 13$ an offer that apparently failed to meet with their approval, for the landing party was threatened with flint-pointed lances. The Spanish nevertheless managed to extricate themselves from this delicate situation without harm to either side. Neither Bodega nor Mourelle say anything in their respective accounts about metallic weapons or ornaments among the people of Los Remedios.

The Sonora later anchored at a place they named

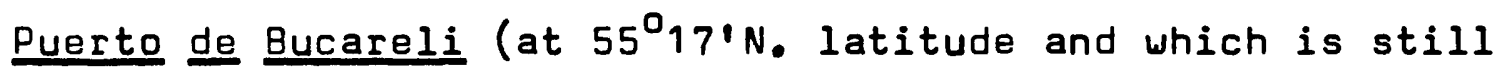
called Bucareli Bay) among the islands off the west coast of Prince of Wales Island just north of Dixon Entrance. Mourelle went ashore with a fow crewmen to take possession, and while he reported seeing "a hut, some paths, and a wooden outhouse, "14 he encountered no natives and apparently left only such objects (unspecified) as the possession-taking ceremony required. 15 Mourelle's account also mentions that they sighted an island some $27 \mathrm{~km}$. south of Bucareli Bay which they called San Carlos (probably today's 
Forrester Island). They had hoped to investigate this island, but adverse winds prevented it. Thus, the first Spanish voyagers in Alaskan waters saw only a handful of natives, and the few they did encounter elicited no comments concerning their possession of European or Asian materials.

In 1779, the Spanish returned to Alaska with two frigates, the Princesa captained by Ignacio Arteaga and her consort the Favorita captained by Bodega y Quadra. Overall command of the expedition was in Arteaga's hands; Francisco Mourelle, Bodega's trusted and able second officer in the 1775 voyage, also accompanied the expedition. 16 They headed first for Bucareli Bay, where they arrived on May 3, anchoring shortly thereafter in a cove on its east shore which they named Puerto de Santa Cruz. Their immediate purpose was to chart the area and determine its usefulness as a possible base for future operations. A survey party, commanded by Mourelle, was sent out in two launches to map the maze of channels and islands surrounding Bucareli Bay. The survey party commenced its operations on May 18, well supplied with provisions, armaments, and trade items including "cloth, baize, beads and some coins for distribution and for faithful witness in the future of the dominion of our august Sovereign."17 The party remained away, except for reprovisioning, until June 12. 
Two days after Mourelle left, the crew of both frigates fell ill from a serious but unspecified disease, 18 resulting in several deaths and requiring the construction of a shelter on shore. About this time, natives began appearing in canoes and crowded around the ships in numbers up to 300 persons, looking for opportunities to trade. The Bucareli Bay Indians, after overcoming some initial reticence, displayed a readiness to exchange "fish, wolfskins, bearskins, mats, and other trifling articles . • for beads and pieces of iron, whereof they made particular account."19 It was also soon apparent that they were no strangers to either copper or iron. One of the chaplains, Fray Juan Riobó, remarked:

They showed us their weapons and even traded us some of them. Their arrows are very finely made; some of them are pointed with flint, some with bone, but most of them have heads of copper and iron and they are very sharp. - - They are extremely fond of iron of which they possess many lances and knives. Their lances are very well made and are very straight and regular in form; some having a spear head twentyfour inches in length with a very long and well made staff. The knives are short with double cutting edges like a carpenter's plane. They are very desirous of obtaining copper and iron but they are chiefly anxious for iron, so much so that as soon as they see a piece of barrel hoop they care no longer for glass beads, mirrors 30 rings or anything else that is presented to them. 20

While it is clear from Riobo's account that metallic weaponry had substantially displaced that of stone or bone, there is no reason to assume these copper and iron objects were necessarily of European or Asian manufacture. Bodega 
mentions seeing copper and iron bracelets, "necklets of extremely fine copper; and in their ears, twisted wires of the same metal," 21 which were probably of native fabrication. If the relatively greater interest in iron is any indication, it would seem that copper objects were more abundant (and less valued) than iron, and that sources supplying the latter metal may have been less reliable and quite possibly of more recent origin than for copper. Spanish attempts to learn from the natives where they obtained these metals met with little success. Bodega wrote:

Respecting the iron and copper they all wear it must be concluded that they may be metals extracted by them from the ore, or that they were brought to this creek by other ships, or that a trade must be kept up with people who can supply them; and in order to ascertain this we omitted no indications or experiments that seemed necessary, but we never got any further results than to fall into greater confusion, for sometimes it appeared to us that they had seen ships, at others that there were places on the borders where people dwelt with whom they traded; and sometimes they pointed to mountains to signify that they got it from there, which is most likely, though anything is possible. 22

Before the Arteaga expedition left Bucareli Bay it would have its share of surprises and difficulties with the natives. A cross erected by the Spanish was torn down "in order to steal the nails," 23 and "so great was their desire to get iron, baize and cloth that it forced several to put aside their affection for their children and hand them over for a few yards of cloth and a knife.n 24 The 
desertion of two Spanish sailors resulted in a serious confrontation in which at least one native was killed. Accounts also mention several instances where natives stole iron knives, chisels, "and even the hook which was used to fasten the companion ladder." 25

Arteaga and Bodega next headed their vessels northward along the coast where, on July 17, they reached a cape in $59^{\circ} 52^{\prime} \mathrm{N}$. latitude, which probably was either the westernmost point of Kayak Island (Cape St. Elias) or nearby Cape Suckling. This was the scene of Bering's original landing in 1741, and thus the Spanish had now closed the gap between their explorations and those of the Russians nearly four decades earlier. Three days later, apparently near the mouth of the Copper River, they were visited, according to Bodega, by "two canoes.. - with two Indians who - - approached us and taking the copper point off one of their arrows handed it to us, which we accepted as a sign of peace used among them." 26 These natives directed the Spanish westward to an inlet which proved to be one of the entrances to Prince William Sound.

At an anchorage probably located at Port Etches on the west side of Hinchinbrook Island, Arteaga carried out possession-taking formalities, calling the place Puerto de Santiago. The expedition now met natives who were very likely Chugach Eskimos, because they paddled up in skin and frame boats instead of dugout wood canoes. 27 Necklets of 
large glass beads were observed among them, and although the Spanish tried to find out where or how they were obtained, all the explanation they got was "that [the natives] had seen other larger vessels enter by the part we were in." 28 Bodega's account says their arrows "were pointed, some with copper and some with flint, in the form of a harpoon," 29 but he says nothing of iron-tipped arrows. 30 Possibly the most unusual sighting reported by the Arteaga expedition was that in which "three pennons, red, blue and white" 31 were seen among some large canoes that visited the ships. Mourelle says these flags were hoisted as they approached "but they struck them before they came alongside." 32 Bodega adds that it was impossible to tell what sort of cloth they were made of .33

The Princesa and Favorita continued westward along the Alaskan coast until they reached the tip of the Kenai Peninsula, in which vicinity they anchored among a complex of islands. On August 2, they landed and took possession; next day, Bodega records, they saw "an extremely high mountain" from which issued "a torrent of thick smoke." 34 But, except for encountering some minor evidence of inhabitants ashore and seeing a few natives at a distance, no significant contact was made with the people in this area. The expedition returned directly to California and no further Spanish ships would return to Alaskan waters until 1788. 
By the time Estebán José Martínez and Gonzalo López de Haro were dispatched in March 1788 to reconnoiter reported foreign settlements on the Alaskan coast, 35 Russian, English, and french ships had long since been making visits up and down the Northwest Coast. Not surprisingly the Martínez-López de Haro expedition and successive Spanish voyagers thus found the natives in possession of a variety of European and Asian materials that originated, in part at least, from these contacts. The accounts of later Spanish voyages nevertheless contain many valuable observations on the changes in material culture that were sweeping Northwest Coast native populations in the last decades of the 18th century. Some of the later Spanish observers, such as Tomás de Suría and Jacinto Caamaño, seemed in particular to have had a high level of interest in the natives, and thus their journals are especially rich in ethnological detail.

Suría was an artist with the Alejandro Malaspina expedition of 1791, whose task was to make a pictorial record of Its visits to Yakutat Bay and Prince William Sound. At Yakutat, or Puerto de Mulgrave as he called it, Suría observed that the natives sought "clothes buttons, which they hang as pendants from their ears," 36 and that they were well supplied with metal weaponry. He described their warriors thus:

They clasp a short lance, a knife, and a hatchet... 
The lance is a heavy stick of black wood, very well worked, and at the point they tie on the blade of a great knife which they obtain from Englishmen in exchange for their skins. The knife which they carry in their belt is the same as ours for the same reason. The hatchet is a black stone of the size, figure, and edge of our iron hatchet. 37

While Suría was no doubt partly correct in attributing these so-called "great knives" to previous English visits, 38 he seems to have been unaware of Russian trading activity at Yakutat in 1788 (or possibly earlier). 39 His statement also implies that the knives "they carry in their belt" were obtained from European traders, yet it is possible that they may in fact have been native-made, locally fabricated, or obtained through native trade channels. 40

When Jacinto Caamaño, commander of the exploring vessel Aranzazu, came to Bucareli Bay in June 1792, he was under orders to "survey the channels that had not been previously examined by our expedition in the year 1779."41 While this survey was being conducted, Caamaño inquired extensively about the customs and everyday life of the natives in the area. He discovered, for example, that "these Indians seemed anxious chiefly to obtain cloth of serge or baize, or other materials that might serve for protective covering. - - They never asked for either iron or copper - - with which they appeared to be well supplied." 42

This was in considerable contrast to the experience of the Arteaga expedition at this same location just 13 years earlier. Caamaño also describes in detail the knives in 
use at Bucareli Bay:

Everyone carries a sheath knife slung around the neck. This is a well sharpened dagger, consisting of a blade some twelve inches long and four in width. The pommel encloses another smaller knife about six inches long and four broad with a rounded point and rather blunt edges, which is used to give the first blows, and for wounding the face. 43

Like Suría, Caamaño at first thought the knives were of European origin, but he later changed his mind:

These knives were so well fashioned and finished that I folt sure they were not of native manufacture, but later I found that the Indians make them themselves quite easily from the iron that they obtain by barter, heating it in the fire and forging it by beating it with stones in the water. 44

Evidence of European trade and influence was nevertheless present in other materials Caamaño saw among the Bucareli Bay Indians. He noticed, for example, that in addition to the usual copper and iron bracelets worn on wrists and ankles, the natives had somehow acquired other ornaments "so extremely heavy as to give the idea of being fetters; especially those that some of the women and most of the men wear around the neck." These peculiar objects, continued Caamaño, "are formed on a twisted, hawser-laid, pattern; and are so large as to reach from one shoulder to the other, as well as partly over the breast." 45 There is little doubt that these collars were introduced into Northwest Coast trade as a result of the visit of the American brigantine Hope to the Queen Charlotte Islands a year earlier in July, 1791.46 
Caamaño's visit to Bucareli Bay would prove to be the last Spanish venture into Alaskan waters in the 18 th century. Unlike most of their Russian, English, and American counterparts, none of the Spanish vessels that probed north of Dixon Entrance was primarily engaged in trade, and thus they were probably the least significant suppliers of nonaboriginal materials to the Northwest Coast. They were on government-sponsored exploring or scientific missions in which trade was of secondary importance. Still, their ethnographic comments are a valuable source of information for the purposes of this inquiry. No metallic weaponry or indication of European contact, for example, was reported among the few natives encountered by Bodega and Mourelle in 1775 on the coast of Kruzof Island. While this is insufficient evidence to generalize about the larger native population, it does suggest that European or Asian materials were scarce enough in 1775 that they had not yet reached some small Tlingit groups. Subsequent Spanish accounts go on to record how swiftly and completely this situation changed. What had seemed an insatiable demand for iron as a raw material at Bucareli Bay in 1779, turned by 1792 into a native preoccupation with fashionable items, such as the twisted iron collars Caamaño saw at Bucareli Bay. 
${ }^{1}$ See pp. 12-13 of this study. Also, for accounts of the voyage and their bibliographic references, see p. 20 , n. 20 .

${ }^{2}$ See pp. 13-14 of this study. Also, for accounts of the voyage and their bibliographic references, see p. 20 , n. 23 .

${ }^{3}$ The outcome of Chirikov's attempted landings at Lisianski Strait in 1749 is uncertain.

${ }^{4}$ Los machos del timón. A more precise rendering would be "rudder pintles," which are the pins or bolts upon which a rudder pivots. p. 36 .

${ }^{5}$ Francisco Antonio Mourelle, Voyage of the Sonora,

6 Juan Francisco de la Bodega y Quadra, "First voyage to lat. 580 .. 1775," P. 7 .

7 Ibid., P. 7 .

${ }^{8}$ Accounts of the Alaskan portion of the Sonora's voyage are in Bodega, "First voyage to lat. $58^{\circ} \cdot 01775$," and Mourelle, Voyage of the Sonora. The Sonora's Alaskan voyage is also described, using extensive quotations from Bodega's journal, in Lucile McDonald, "The Sonora," Alaska, 39, No. $2(1973)$.

9odega, "First voyage to lat. $58^{\circ}$. . 1775," p. 11.

10 If, as seems likely, Bodega's Los Remedios was Sea Lion Cove, the only previous European contact anywhere close was at Lisianski Strait, some $70 \mathrm{~km}$. up the coast, where Chirikov lost two boats and 15 men in 1741 .

11 Mourelle, Voyage of the Sonora, p. 44. Bodega, "First voyage to lat. $580 \div \frac{1}{1775, "} \mathrm{p}$. 11 , says 10 men went ashore.

12 Bodega, P. 12 .

${ }^{13}$ Ibid., p. 12. Mourelle, as translated by Barrington, $p$. 45 , says they traded "bugles and small pieces of cloth," apparently meaning tubular glass beads and handkerchiefs.

$$
14 \text { Mourelle, P. } 49 .
$$


15 Spanish acts of possession in the 18 th century primarily involved erecting a cross and performing prescribed formularies. Sometimes bottles were buried containing the written act of possession or, as Mourelle, $p .44$, described at Los Remedios in 1775, a cross might be carved on a rock. See Wagner, "Creation of Rights of Sovereignty Through Symbolic Acts," Pacific Historical Review, 7, No. 4 (1938), Pp. 297-326.

16 Accounts of this voyage used here are: Juan Francisco de la Bodega y Quadra, "Second Expedition up to 610 ... 1779"; "Extract from the Account of a Voyage made in 1779 by Don Francisco Antonio Maurelle," in La Pérouse, A Voyage Round the World $\cdot \cdot$ in the years 1785, 1786, 1787, 1788, I, 242-255; and Walter Thorton, trans, and ed., "An Account of the Voyage made by the Frigates 'Princesa' and 'Favorita' in the year 1799 [sic. 1779] from San Blas to Northern Alaska," The Catholic Historical Review, 4, No. 2 (1918), PP. 222-229. See also Warren Cook, Flood Tide of Empire, PP. 88-100, for a discussion suggesting that the underlying motivation of the Arteaga expedition was to intercept Cook's two vessels, the Resolution and Discovery.

17 Bodega, "Second Expedition • • 1779," p. 28.

18 Bodega's mention, p. 29, of this epidemic includes few clues as to its nature. There has been speculation that it was smallpox and that this episode may have been the source of one of the early epidemics of that disease among Northwest Coast Indians (see Cook, Flood Tide of Empire, P. 80).

${ }^{19}$ Bodega, "Second Expedition •. . 1779," p. 29.

20 Thorton, "An Account of the Voyage made by the Frigates 'Princesa' and 'Favorita!," p. 224 .

21 Bodega, "Second Expedition • • 1779," p. 37.

22 Ibid., P. 42.

23 Ibid., P. 35.

24 Ibid., P. 30.

25 Ibid., P. 32 .

26Ibid., P. 45. These people were probably Eyak Indians, or possibly Chugach Eskimos.

${ }^{27}$ The Spanish were intrigued by these light, maneu- 
verable craft, likening them to a harp "for even their very prow forms the curve which is required in the [harp] for fastening the strings" (see Bodega, pp. 46-47).

28 Since Cook visited Prince William Sound the previous year it seems likely these beads and the ships referred to by the natives were connected with the visit of the Resolution and Discovery in May, 1778 (see Beaglehole, The Journal of Captain James cook, III, pt. 1, 343-356).

29 Bodega, "Second Expedition • • 1779," P. 47.

${ }^{30}$ Neither do the Mourelle nor Riobó accounts mention iron-tipped weapons at Prince William Sound.

31 Bodega, p. 47.

32 Mourelle, "Extract from the Account of a Voyage made in 1779," P. 253.

33 Bodega, "Second Expedition - • 1779," p. 47. Warren Cook, Flood Tide of Empire, $\mathrm{P} .97$, says the Spanish saw "a red, white, and blue flag" which leaves the erroneous impression that some type of European national flag was seen. This seems doubtful since the flags are described in the plural, each being a separate color. It will be recalled that Bodega also mentioned seeing a white pennon on a pole at Los Remedios (see "First Voyage •. . 1775," p. 12).

34 Bodega, "Second Expedition - . 1779," P. 49. This was probably $3,060 \mathrm{~m}$. Illiamna Volcano on the north side of Cook Inlet.

${ }^{35}$ For accounts of the 1788 Martínez-López de Haro expedition see Wagner. The Cartography of the Northwest Coast, I, 202-205; Cook, Flood Tide of Empire, pp. 119-129; and Mary Gormley, "Early Cultural Contact on the Northwest Coast, 1774-1795," Northwest Anthropological Research Notes, 11, No. 1 (1977), pp. 14-17. $\frac{\text { The expedition visited pince }}{\text { Tition }}$ William Sound in May 1788 and made contact with the Russian fur traders Delarov and Zaikov. According to Cook, Flood Tide of Empire, P. 594, none of the extent journals of this voyage has been published. P. 37 .

${ }^{36}$ Donald C. Cutter, ed., Journal of Tomás de Suría,

37 Ibid., P. 46.

${ }^{38}$ George Dixon in 1787 and James Colnett in 1788 traded with the Yakutat Tlingits (see Dixon, Voyage Round the 
World, PP. 167-177, and Colnett, "Journal of the 'Prince of Wales'," MS., entries for May 31 to June 9, 1788). 39

See pp. 43-45 of this study.

40 De Laguna, Under Mount St. Elias, III, 1078, illustrates a copper war knife or dagger found at the Alsek River (about $96 \mathrm{~km}$. south of Yakutat Bay) by George Emmons, which in all probability was native-made yet which could easily be mistaken for European because of its careful workmanship. One of Suria's drawings of a Yakutat Tlingit shows the man holding a dagger very similar to the Emmons find (see Thomas Vaughan, et al., Voyages of Enlightenment, P. 34, fig. 17).

${ }^{41}$ Henry R. Wagner and $W . A$. Newcomb, eds., "The Journal of Don Jacinto Caamaño," British Columbia Historical Quarterly, 2, No. 3 (1938), p. 202 .

$$
\begin{aligned}
& 42 \text { Ibid., PP. } 202-203 . \\
& 43 \text { Ibid., P. } 203 . \\
& 44 \text { Ibid., P. } 203 . \\
& 45 \text { Ibid., P. } 206 . \\
& 46 \text { while anchored in Parry Passage between Langara and }
\end{aligned}
$$
Graham islands, the Hope's captain, Joseph Ingraham, hit upon the idea of having his smith "make iron collars of three rods twisted together about thw size of a man's finger. - . When finished they weighed from five to seven pounds and would purchase three of their best skins in preference to anything we had on board" (see Joseph Ingraham, Voyage to the Northwest Coast of North America, 179092, p. 105; and pp. 141-143 of this study. 
CHAPTER $V$

\section{ENGLISH VOYAGES}

James Cook was the first English mariner to visit Alaskan waters. His two ships, Resolution and Discovery, sailed from the Hawaiian Islands to the Oregon coast and then worked their way northward in the spring of $1778 .^{1}$ Except for a month-long stay at Nootka Sound on Vancouver Island, Cook made no landings or native contacts until he reached Kayak Island, southeast of Prince William Sound. There, on May 11, at a point very close to where Steller had landed 37 years earlier, the English went ashore in Alaska for the first time. "At the foot of a tree on a little eminency not far from the Shore, I left a bottle in which was an Inscription seting forth the Ships Names, date $\& c^{a}$ and two Silver two penny pieces (date 1772)." 2

Proceeding westward from Kayak Island, the Resolution and Discovery came upon "the East point of a large inlet" 3 that proved to be the eastern entrance to Prince William Sound. Behind this point, which Cook named Cape Hinchinbrook, 4 they anchored in a cove that very likely was close to the same anchorage used the following year by the Arteaga expedition. Cook's two ships, like the Spanish later, were 
soon visited by natives in frame and skin boats, who were probably Chugach Eskimos. "When these people first came to the Ships," Cook wrote, "they displayed a white dress and unfolded their arms to the utmost extent, this we understood to be a sign of friendship." 5

On May 13, they proceeded northward farther into the sound to a more protected anchorage that Cook named Snug Corner Bay. There on the following day some of the natives came aboard the Resolution and Cook's attention was drawn to one individual in particular who

was cloathed in a dress made of the Sea beaver [otter] skin and on his head such a Cap as is worn by the people of King Georges [Nootka] Sound, ornamented with sky blue beads about the size of a large pea; these he seemed to set ten times more Value upon than our white glass beads which they probably thought was only crystal which they have among them. They however esteemed beads of all sorts and gave whatever they had in exchange for them, even their fine Sea beaver
skins. 6

There is also mention of seeing "some bugle [tubular glass] beads strung on a stif string or Cord 3 or 4 inch long, run through the cartilage that divides the nostrils from each other." 7 Lieutenant James King of the Resolution, in reflecting on the beads possessed by the Prince William Sound natives, observed that

the most certain proofs of their hav a frequent supply of articles belonging to civiliz'd Nations are their blue beads; these of which they set a very great Value, have not the good shape of English beads but are manufactur'd by some Nation ruder in this art than ourselves, they are a bead about the size of a large currant berry, \& intended to be (but are not) round. I shou'd imagine that they 
have not a direct communication with any civiliz'd people, many parts of their behaviour seem to shew it, even in beads they appear to have no knowledge of any other than their own sort; for Although we had so great a Variety both as to Colour \& size, yet from not being precisely of the same Colour \& shape as their own, they always shwd a suspicion of there being some deception in them. 8

Nevertheless, he avers that beads were their most reliable trade item, even if the natives could be extremely fickle in their taste. Illustrating this, King continues:

A green bead of an Oval figure as big as a small plumb, which one of our Gentlemen got from an Otaheite [Tahiti] man that had receivid them from the Spanyard, was so eagerly seiz'd on that the Chief sold 8 or 10 sea Otter skins (worth by the Russian accounts at China between 2 \& $300 £$ ) for double the number of the Beads; but such was the fickleness or suspiciousness that next day the Gentlemen, who had not $\frac{1}{2}$ a Dozen left, coud get no such prices for them. 9

It seems likely that the sky blue beads were of European origin, for large numbers of such glass beads (probably including Lieutenant King's so-called "English" beads and the green beads obtained from a "Spanyard") are believed to have been made in 18 th century Italy at the glass factory of Murano, Venice. 10 The presence of glass beads at Prince William Sound indicates, as King remarked, that trade connections must have existed between its native inhabitants and others who were in contact with suppliers of such beads. 11 Another somewhat less likely possibility is that some unrecorded non-aboriginal visitors had distributed the beads before Cook's arrival.

The English learned that their native guests were 
very discriminating about other materials they took in trade as well:

These people [wrote Cook] were also desirous of iron, but it must be pieces eight or ten inches long at least, and three or four fingers broad for small pieces they absolutely rejected; consequently they got but little from us, as it was now become rather a scarce article. 12

And finally, Cook observed that "the points of some of their spears or lances, were of iron shaped in the form of a Bear spear, others were of Copper and few of bone."13 On May 20, the Resolution and Discovery departed the sound (upon which Cook bestowed the name Sandwich), heading southeastwardalong the Kenai Peninsula on roughly the same course Arteaga and Bodega would take the following year. Unlike his Spanish colleagues, however, Cook found the large waterway (today called Cook Inlet) that turns inland along the northwestern coast of the Kenai Peninsula. The natives of Cook Inlet, he found, were little different from those of Prince William Sound, and they possessed the same sky blue beads and iron implements. A landing party went ashore at Possession Point (at the south entrance to Turnagain Arm) on June 1 "to display the flag, take possession of the Country and River in his Majestys name and to bury in the ground a bottle containing $t[w]$ o pieces of English coin (date 1772) and a paper on which was in [s] cribed the Ships name date $\& c^{a} . " 14$

In reflecting on how the natives of Cook Inlet re- 
sembled those of Prince William Sound, and on how dissimilar both were from those of Nootka Sound on Vancouver Island, Cook observed:

Their spears are like a Spontoon [a shafted weapon with broad blade and basal crossbar] and their knives, which they kept in sheaths, are of a considerable length, these with a few glass beads were the only things we saw amongst them that were not of their own Manufacture. It is probable they may get them from some of their Neighbours with whome the Russians may have a trade, for I will be bold to say that the Russians were never amongst these people, nor carry on commerce with them, for if they did they would hardly be cloathed in such valuable skins as those of the Sea beaver [otter]; the Russians would find some means or other to get them all from them. 15

The expedition proceeded from Cook Inlet south and southwesterly along the south coast of Kodiak Island (mistakenly assuming it to be part of the mainland) and through the Shumagin Islands off the Alaska Peninsula. On June 19, somewhere near the southeastern extremity of Unga Island (one of the Shumagins) the captain of the Discovery, Commander Charles Clerke, reported an encounter with

some Indians in three or four Canoes, who had been following the ship for some time. . An Indian in one of them made many signs, took of [f] his cap and bowed after the manner of Europeans, which induced them [the crew of the Discovery] to throw him a rope, to which he fastened a small thin wood case or box and then, after speaking something and making some more signs droped astern and left them. 16

The box was found to contain a carefully folded piece of paper bearing "some writing in the Russian language, as was supposed, with the date 1778 prefixed to it, and in the body of the note was something that refer'd to 
the year 1776." 17 Clerke speculated that perhaps some Russians were shipwrecked in the vicinity, while cook thought it more likely that it was a message left by a previous Russian trader to be delivered to one of his countrymen. They later found, as explained by the expedition's astronomer, William Bayly, "that it was a receipt for Tribute paid to the Russians," leading him to conclude that "this [Unga Island] seems to be the farthest East that the Russians trade along the Coast of America." 18

As the expedition pushed westward to the Fox Islands (easternmost of the Aleutians), it encountered other natives who similarly possessed notes written in Russian, bowed politely doffing their hats, and among whom at least one was attired in "a pair of green cloth breeches and a Jacket of black cloth or stuff under his own gut shirt or frock."19 The evidence of Russian contact was unmistakable and fairly widespread, although the English saw no Russian promyshlenniki themselves. After a brief stop (June 29 to July 2) at a harbor the natives called Sam goonsodha (English Bay on Unalaska Island), the expedition turned northeastward to explore Bristol Bay, where indications of European contact diminished noticeably. Describing natives they encountered July 21 near Cape Newenham (at the northwest extreme of Bristol Bay, Cook wrote:

They appear to be wholly unacquainted with people like us, they knew not the use of Tobacco, nor was anything foreign seen about them, except a knife 
may be looked upon as such. This indeed was only a piece of common iron fited into a wooden handle, so as to answer the purpose of a knife; they however knew the value and use of this instrument so well that it seemed to be the only thing wished for. 20

These were Bering Sea Eskimos, closely related to the Chugach and Koniaga (Kodiak) Eskimos, and more distantly affiliated with the Aleuts. In addition to the distribution of "some trifles" among the Bristol Bay people, Cook sent a party ashore at Cape Newenham to take possession by leaving the usual bottle. 21

The Resolution and Discovery next sailed northward to Bering Strait, where they sighted the western extremity of North America on August 9, naming it Cape Prince of Wales. "We thought we saw some people upon the coast," Cook wrote, "and it is likely we were not mistaken, as some elevations like stages and others like huts were seen at the same place."22 But nothing further came of the sighting. Crossing over to the Asiatic side of Bering Strait, Cook's ships anchored on the Chukotskii Peninsula at Lavrentia Bay (just southwest of Cape Dezhnev, the eastern extremity of Siberia), where three boats were sent ashore on August 10. Between 40 and 50 well-armed native men (the women and children had fled) warily met the English landing party, and after some uneasy moments Cook and his men exchanged knives, beads, and tobacco for native clothing and a few arrows. 23

The people encountered at Lavrentia Bay, in Cook's 
words, "appeared to be a quite different Nation," which indeed they were. 24 In describing their weapons, he noted:

The Arrows were pointed with either bone or Stone, but very few were barbed and some had a round blunt point of bone. - . The Bow [s] were such as we had seen on the American coast and like those used by the Esqumaux's; the Spears or Spontoons were of Iron or steel and of European or Asiatic workmanship in which no little pains had been taken to ornament them with carvings and inlayings of brass and white Metal.

Later, in reflecting on these spears or so-called "spontoons," 26 Cook concluded that they must have been obtained in "trade with the Russians either directly or by means of some neighbouring nation."27 Although these people (the Chukchi) greeted the English with low bows and doffed hats much as the Aleuts had, there was no other evidence to suggest they were in any way subject to Russian authority. 28

The expedition now voyaged into the Arctic waters north of Bering Strait where opportunities for native encounters were all but precluded. It is thus not until after their return south through the strait that mention is again made of natives. After coasting southwestward along the Chukotskii Peninsula, Cook turned eastward toward the American shore, entering Norton Sound. After a fleeting glimpse of some people in canoes on September 7 on the sound's north shore, they made contact four days later with inhabitants at a cape they named Denbigh. Al though there was little at first to suggest these people 
had been visited by Europeans, Cook's description of the Cape Denbigh Eskimos contains a hint that such contact might have been possible. He wrote:

Several people were seen on the Peninsula [Cape Denbigh] and one man came off in a small Canoe, I gave him a knife and a few Beads with which he seemed well pleased. I made signs for him to bring us something to eat, he immidiately left us and paddled for Shore, but meeting another man coming off, returned with him with two dryed Salmon he had got from the other man, which he would give to no one but me whom we thought he asked for by name of Capitane, but in this we were probably Misstaken, because I do not see how he could know that I was the Captain. Some others came off afterward and exchanged a few dryed fish for such trifles as they could get. - . Knives they were the most desirous of and they had no dislike to Tobacco. 29

Before Cook left the Cape Denbigh anchorage he also observed that its inhabitants possessed glass beads "as I have before noticed" (presumably meaning they were sky blue in color), and that "iron was their beloved Metal, for four knives made out of an old iron hoop I got from them near 400 pound of fish." 30

On October 3, 1778, the Resolution and Discovery, returning southward, anchored once more at English Bay on Unalaska Island where they stopped in July. Five days later one of the natives there 31 brought Cook "a very singular present . . a rye loaf or rather pie made in the form of a loaf, for some salmon highly seasoned with peper \& ${ }^{a}$ was in it." 32 Commander Clerke received a similar present, and both officers were handed notes in Russian that left no doubt that these had come from nearby Russian 
promyshlenniki. In an effort to reach these "unkown friends," as Cook referred to them, 33 Corporal John Ledyard, a marine aboard the Resolution, volunteered to go with the natives to locate the senders of those curious loafs. Ledyard returned shortly 34 with three Russians, and others soon followed.

One of the Russian visitors to Cook's anchorage proved to be the person in charge of the fur gathering operations at Unalaska and its neighboring islands. His name was Gerassim Grigorovich Izmailov ${ }^{35}$ and, despite severe language difficulties (no one among the English spoke Russian nor did Izmailov or his a sociates speak English), he managed through the aid of a chart and signs to convey some information concerning Russian exploration in the Aleutians, of which Cook wrote:

It appeared by the Chart as well as by the testimony of I smyloff and others that [Unimak Island, just northeast of Unalaska] is as far as the Russians have discovered and extended themselves sence Behrings time, they all said no Russian had been where the Indians gave Captn Clerke the note, which MI Ismyloff, to whom I gave it said was written at Donanak [Umnak Island, just southwest of Unalaska]. It was however from him we got the name of the Island Kodiak the largest of the Shumagens islands for it had no name upon the Chart. 36

Cook's last remark tends to belie the conclusion he had just reached about the limits of Russian voyaging, since the name Kodiak applied to an island far to the east of Unimak Island (the supposed eastward limit of Russian exploration). Moreover, in considering Kodiak Island one of 
the Shumagins, Cook seemed not to have realized that it was in fact situated well to the east of those islands. 37 It is also difficult to reconcile iasak receipts in the shumagin Islands with Cook's conclusion, since they had no value unless Russian promyshlenniki occasionally visited the area collecting tribute. One can only surmise that the language difficulties resulted in Cook hearing what he wanted to hear (namely, that the Russians had not already penetrated lands so recently claimed in the name of the English sovereign), or Izmailov purposely withheld the true extent of Russian eastward expansion, or possbily a combination of both.

Before Cook left Unalaska, he noticed that even though the Aleuts there were in direct and frequent association with the Russians they possessed surprisingly few and only simple metal tools and virtually no such weapons. Describing their household furnishing, he noted:

Their household furniture consists in bowls, spoons, buckets, piggins or cans, Mated baskets, and perhaps a Russian kettle or pot, all these things are very neatly made and well formed and yet we saw no other tools among them but a knife and a hatchet, that is a small flat piece of iron made like an adz by fiting it into a crooked piece of wood. These were the only instruments they had made of iron, for altho the Russians live amongst them they had far less of this Metal, than those who never saw a Russian. 38

Not only were the Unalaska Aleuts meagerly supplied with such equipment, but they seemed uninterested in acquiring more. Cook remarked that practically anything they had to spare could be purchased from them for a few 
beads, a little tobacco, or snuf:

There are [he continues] few if any that do not both smoke and chew Tobacco and take snuf, a luxury that bids fair to keep them always poor. They did not even seem to wish for more iron or want any other instruments, except sewing needles, their own being made of bone, with which they not only sew their Canoes and make the $\frac{i}{3}$ cloaths, but make also very curious embroidery. 39

These comments bear witness to the success of Russian policies designed to prevent the Aleuts from carrying out uprisings like the one in 1763. The natives were deprived of weaponry appropriate for warfare and their psychological dependency on small luxuries seems to have been encouraged. Thus, as Cook observed, the natives living outside of direct Russian control were better supplied with metallic weapons than the Aleuts who lived in closest association with them.

Cook left English Bay and Unalaska on October 26, 1778, bound for Hawaii, where he planned to winter before returning north to Kamchatka. He was not destined, however, to see Alaskan waters again because of his death at Kealakekua Bay, Hawaii, in February, 1779. The expedition, under Commander Clerke's leadership, went north again to Petropavlovsk in Kamchatka and thence once more through Bering Strait, but the expedition made no further contacts with Alaskan or Northwest Coast natives.

It would have been difficult for subsequent English mariners visiting northwestern North America to match the 
ethnographic richness of the records describing Cook's 1778 voyage. Later English expeditions in the northeastern Pacific had commercial objectives that tended to overshadow scientific observation, and they were usually undertaken by men who, like the promyshlenniki, were more interested in pelts than ethnography. The narratives of their sojourns on the Alaskan coasts often merely confirm or reflect what Cook had already learned in 1778. Nevertheless, in some instances new and even significant pieces of information emerge from the records of these commercial expeditions concerning the natives' possession of non-aboriginal materials.

James Hanna, commanding the brig 40 Harmon (or Sea Otter), was the first English mariner to return to the northeastern Pacific, acting on the discovery that sea otter pelts would bring handsome prices in Canton. It is known that Hanna sailed out of Macao on April 15, 1785, and reached Nootka Sound on August 9, that same year, but his movements north of there are too uncertain to be of use in this inquiry. 41 In the following year, however, at least three well-documented English fur-trading expeditions sailed in Alaskan waters.

In mid-July, 1786, two ships, the King George captained by Nathanial Portlock and the Queen Charlotte under George Dixon, sailing out of London, reached Cook Inlet by way of Cape Horn and the Hawaiian Islands. 42 Their inten- 
tions were to trade for pelts among the Alaskan natives. Thinking they were the first such vessels to visit there since Cook's expedition in 1778, they had high hopes for success. On July 19, however, as they approached a prospective anchorage 43 on the eastern shore of Cook Inlet a short distance north of Cape Elizabeth, their confidence was unexpectedly shaken. Portlock wrote:

Just at this time we were greatly surprised to hear the report of a great gun from the shore; [fog] was now very thick over the land, which prevented us from seeing the smoke of the gun; however, we fired a gun and hoisted our colours, and presently afterwards fired another, expecting it would be answered. Immediately after our firing the second gun another was fired from the shore, in the direction of East, three quarters South. It was now very evident, that some nation or other had got to this place before us, which mortified me not a little. Soon after this we perceived a boat rowing out towards the ships; on which, we tacked and stood in shore, in order to meet her: by seven o'clock the boat came on board, and I found the people to be Russians. 44

There were at least 25 members in the Russian party, including natives of Unalaska and Kodiak (three of whom were women). Language difficulties impeded communications, but Portlock learned that they had come "last from Kodiac, an island near the Shumagins, on a trading expedition; that they left their vessel at Kodiac, and proceeded to Cook's River [Inlet] in boats." 45 They apparently were part of the expedition Shelikhov had dispatched in the spring of 1786 to subjugate the rebellious Kenai natives. 46

Despite the presence of these competitors, the two English ships pushed on into Cook Inlet with modest trading 
success, but without adding much to the ethnographic observations recorded during Cook's stay. The principal items in demand were so-called "toes" (chisel-like iron blades as much as two feet long) and beads--usually the light blue variety, although sometimes only green or red beads were accepted. There was little interest, however, in manufactured items like hatchets, adzes, saws, or metal cooking utensils. 47 One of the natives sought to enlist the aid of the English in resisting the Russians, a request that was politely refused. "But," Portlock remarked, "to console him in some measure for his disappointment, I gave him a light horseman's cap, of which he was very proud."48 The two ships skirted Prince William Sound in August, unable to gain entrance, and moved from there southeastward along the coast seeking an anchorage in which to spend the winter. Poor weather and the sketchiness of their information, however, prevented them from locating a safe harbor on the North American coast, and they instead returned to Hawai for the winter.

Within days of Portlock and Dixon's departure from Prince William Sound, a second English expedition appeared off Cape Hinchinbrook at the sound's east entrance. It included two ships, the Captain Cook and Experiment, owned by and under the overall direction of James Strange. 49 These ships had sailed out of Bombay on December 8, 1785, entering the Pacific by way of the Sunda and Makassar 
straits and crossing the North Pacific to Nootka Sound (June 28, 1786). After spending a month at Nootka, where he introduced the natives to the novelty of cymbals as trade items, 56 strange proceeded northward exploring Queen Charlotte Sound and the north end of Vancouver I sland before going on to Alaskan waters.

When the Captain Cook and Experiment reached Prince William Sound (August 29), they discovered the natives there were both few in number and

almost Destitute compared with Our Nootka Friends; these appeared little Versed in the Art of Traffic; and never hesitated a moment, accepting any offer that was made to them, they as readily concluded the Bargain for One Bead; as they would have done for twenty. Color alone constituted the value of the Offer; and none other than sky blue, would have been received although the number offered had been ten times multiplied. 51

It is curious, as Strange himself noted, that these natives seemed to behave so differently from those that Cook had encountered and described there in 1778. Whatever may have been the reasons for this, Strange's account offers few clues as to what the underlying explanation might have been. Unlike the Portlock-Dixon expedition, Strange saw no evidence of Russian activity and mistakenly concluded that:

It is a singular Proof of the Inactivi [ty] and want of Enterprise in the Russians, belonging to Kamchat$k a$, that they have not yet availed themselves of this new source of wealth, laid open to them, by the Discoveries of Captain Cook. I believe I may venture confidently to affirm, that hitherto they have not found their way to the coast of America; which 
is the more unaccountable, when it is considered that, from Onalaska Islands, to which they have for a great length of time traded, they could easily reach Prince William's Sound, or Cook's River [Inlet], in ten or twelve Days. 52

On September 5, Strange was surprised by the appearance of another ship at Prince William Sound, dashing any hopes he had of a trade monopoly, however temporary. The new entry was another English ship, the snow ${ }^{53}$ Sea otter (not to be confused with Hanna's brig which apparently also went by this name) under William Tipping, who had sailed from Calcutta in March, 1786. Tipping had actually set out in company with another vessel, the Nootka under John Meares, with plans calling for the two ships to sail separately for a rendezvous on the North American coast. 54 With Tipping in the lead, they sailed similar courses that took them north past Japan and eastward through the Aleutian chain to southern Alaska.

About the time Tipping arrived at Prince William Sound (September 5), where he was supposed to meet Meares, the Nootka was somewhere in Shelikof Strait proceeding eastward between Kodiak Island and the Alaskan mainland. There, Meares encountered a Russian party that had just left Cook Inlet headed for their winter quarters on Kodiak Island--no doubt the same Russians that Portlock and Dixon had seen in July. The Nootka reached Prince William Sound after Strange and Tipping had left, anchoring on September 25 at a cove that Meares believed was Cook's 
Snug Corner Bay. 55 There he noticed that someone else had been there recently:

In our excursions on shore Meares wrote, we saw some wood which had been fresh cut, and by an edge tool; we also found a piece of bamboo, which fully satisfied us that some vessel must have very likely preceded us; and as our appointed rendezvous, with our consort the Sea Otter, was at this place, we very naturally concluged that she had been here, and was sailed for China. 56

Meares decided to spend the winter at this anchorage, an ill-advised decision, for by spring 23 of the ship's 45 officers and men would perish from scurvy. 57 In the course of this unhappy experience, with their ship frozen fast in the ice, they had numerous occasions to observe and trade with the local population, about whom Meares wrote:

The article which the natives esteem most is iron, and they would prefer such pieces, as approached, in any degree, to the form of a spear--Green glass beads are also much sought after, and at times those which are red and blue.-They were very fond of our woollen jackets 58 or any of the old cloaths belonging to the Apparently the large green beads mentioned by Lieutenant King in 1778 had worked a lasting effect on some of the Prince William Sound natives.

In May 1787, Portlock and Dixon returned to Prince William Sound from Hawaii, unexpectedly discovering Meares and the pathetic remnant of his crew huddled on the Nootka, not quite thawed from the ice that had held her fast all winter. After rendering assistance to the distressed Nootka (which Meares later claimed was half-hearted), 59 
Portlock and Dixon separated. The King George remained at Prince William Sound, sending her longboat to trade in Cook Inlet, while the queen Charlotte set out to trade along the coast to the southeast.

Dixon reached Yakutat Bay on May 23, 1787, anchoring in a location among some islands just inside the bay's south entrance which he called Port Mulgrave. This was, he believed, the first time a European ship had entered the harbor, and he was hopeful this would enhance their fur trading prospects. William Beresford, the ship's supercargo, described their first encounter with the natives:

The people seemed very well pleased at our arrival, and a number of them presently came along-side us. They soon understood what we wanted, and an old man brought us eight or ten excellent sea otter skins. This circumstance, together with our having as yet seen no beads, or other ornaments, or any iron implements, gave us reason to conclude, that no trading party had ever been here, and consequently that we should reap a plentiful harvest; but ... on a further acquaintance with our neighbours, they shewed plenty of beads, and the same kind of knives and spears we had seen in Prince William's Sound; and as a melancholy proof that we only gleaned after more fortunate traders, what furs they brought to sell, exclusive of the small quantity just mentioned were of very inferior kind. 60

Beresford did not speculate as to who these "more fortunate traders" might have been or when they may have visited Yakutat Bay. He was unaware that the French explorer Jean F. G. de La Pérouse had sent two boats into this bay in June, 1786, but they had engaged in no trading activities. 61 Nothing in the records of Cook's 1778 
expedition or of Strange's 1786 voyage suggests that their vessels put in or traded anywhere near Dixon's Port Mulgrave. Meares, who came to Prince William Sound by way of Japan and the Aleutains and eventually returned to China by way of Hawaii, had no opportunity to visit this section of the North American coast before 1787. Hanna (after August 9, 1785) and Tipping (after September 5, 1786) were the only English mariners who might have preceded Dixon to Yukutat Bay, and considering its relative proximity to Tipping's last known position (at Prince William Sound) it is possible that his ship put in there sometime in the fall of 1786. Beresford's remark that the Yakutat beads, knives, and spears were the same as those seen at Prince William Sound also hints at the possibility that Russian promyshlenniki had either traded there before 1787 or that a native trade link existed between the Cook Inlet-Prince William Sound vicinity (where Russian traders had operated at least since 1783) and Yakutat Bay. 62

The Queen Charlotte next (June 12) put in at a roadstead they called Norfolk Sound, the Guadalupe of Bodega's 1775 voyage, and known today as Sitka Sound. The natives greeted them displaying what seemed at first a white flag, but which on closer examination proved to be a "tuft of white feathers which they had hoisted at the top of a long pole." 63 They were eager for trade, with strong preferences for certain items: 
Toes [iron chisels] are the articles of traffic held in the first estimation at this place; but they always refused small ones, wanting them in general from eight to fourteen inches long. Besides these, we traded with pewter basons, hatchets, howels [?], buckles, rings, \&c. Of these the basons were best liked; for though the hatchets and howels were obviously the most useful tools these people could possibly have, yet they were only taken in exchange for furs of inferior value. Beads of every sort were constantly refused with contempt, when offered by way of barter, and would scarcly be accepted as presents. 64

The natives informed their visitors that two large ships (one of which was said to be considerably larger than the Queen Charlotte) had anchored nearby "a good while ago." 65 Upon being shown a white shirt that the natives said they had obtained from these earlier sojourners, Beresford concluded from its apparent "Spanish fashion" that it must have been left by Bodega in 1775. This is hardly likely, however, since aside from the improbability of a shirt surviving intact for 12 years, Bodega had only one ship, and a small one at that. ${ }^{66}$ Doubtless, the shirt had come from La Pérouse's Boussole or Astrolabe, both three-masted frigates, when they explored this coast in August, 1786. 67 After a brief and uneventful stop at whale Bay on the southwest coast of Baranov Island, the Queen Charlotte headed south to trade in the Queen Charlotte Islands during July, eventually reaching China by way of Hawaii.

Meanwhile, Portlock, in the King George, having finished trading in Cook Inlet and Prince William Sound, made 
his way in early August southeastward across the Gulf of Alaska to an anchorage on the west coast of Chichagof Island that still bears Portlock's name today. ${ }^{6}$ He remained there for about two weeks, long enough to record some interesting and important observations relevant to this inquiry.

Portlock, like Dixon at Yakutat Bay, was confronted with evidence that he and his crew may not have been the first Europeans seen by the natives of Portlock Harbor. Besides possessing numerous beads "of quite a different sort to any I ever saw," the natives had a "carpenter's adze made in a different manner to ours, with the letter $B$ and three fleurs-de-1is on it." 69 Portlock says that a chief informed him that these articles had been obtained from two three-masted vessels that had visited them somewhere northwest of Portlock Harbor. He concluded that this probably referred to the "French men-of-war [La Pérouse's Boussole and Astrolabe] that were fitting out for discovery at the time we left England." 70

A third vessel was also mentioned by the natives. This one, a two-master, had reportedly made the coast "a little way to the North West," and because "they described her having only two masts, and her boat like our whale boat," Portlock assumed she was Dixon's Queen Charlette. 71 Whatever her identity, the natives explained she had met with misfortune: 
They also made me understand very clearly, that an unfortunate accident happened to one of her boats, which was fishing at an anchor [age] in the mouth of the port where she lay: whilst fishing, the wind came in fresh from the sea, which caused a good deal of sea to set in, and when endeavouring to weigh their anchor, the cable slipped on the broad-side of the boat, which overset her; and before any assistance could be 7 iven them from the ship five men were drowned. 72

The Beresford account of Dixon's voyage says nothing about such an incident nor did the Queen Charlotte anchor off a port that could reasonably be described as located "a little way" northwest of Portlock Harbor. 73 Thus it seems the unhappy story of this third vessel must have originated in some other visit to the area, possibly by Hanna's brig in 1785, or Tipping's ill-fated Sea Otter in 1786, or a Russian vessel. 74

Shortly before Portlock left his anchorage on Chichagof Island, he would record more spectacular and visual evidence of European contact. One of the chiefs who had visited them frequently--Portlock called him "my old acquaintance" 75 -returned one day in great pomp and ceremony, determined to entertain his English guests with music. Portlock described him:

His dress was an old coat, made of cloth which formerly had been scarlet, with some old gold or silver fringe about the shoulders; but that ornament being esteemed of little value, the cloak was decorated down each side with buttons, and small lead pipes, each about an inch long. His hair, after being well rubbed with oil, was entirely filled with down taken from gulls. - . In this grotesque figure he displayed as much importance as any Spanish don could possibly have done. Besides the curious dress which 
the chief himself wore, he had another in the boat not less remarkable than his own, and ornamented nearly in the same manner, which was worn during the time of their singing by a woman whom I took for his wife. 76

This description is among the earliest in which Northwest Coast Indians (in this case, Tlingits) were seen adapting European clothing to ceremonial purposes. The most likely source of these coats would have been La Pérouse's visit in 1786, since the natives of Portlock Harbor had other articles apparently attributable to that source. 77

Portlock and Dixon had no sooner departed the Alaskan coast than they were replaced by a second expedition outfitted by the same London-based firm, the King George's Sound Company, and licensed by the South Sea Company. Two. ships, the Prince of Wales under James Colnett and the Princess Royal captained by Charles Duncan, had arrived at Nootka Sound in July, 1787, and by remarkable luck they were sighted off the coast there on August 8 by Dixon as he was returning south. It was at this time that Dixon urged his colleagues aboard the Prince of Wales and Princess Royal not to go north to Alaska but instead to concentrate their trading efforts in the Queen Charlotte Islands. 78 While they apparently heeded this advice at first, Colnett is known to have proceeded north alone the following spring and summer (1788) when he visited both Prince William Sound and Yakutat Bay. 79

Colnett's account of his sojourn at Yakutat Bay, or 
Foggy Harbour as he called it, contains material particularly relevant to this inquiry. It was May 31, 1788, when the Prince of Wales anchored off the same bay Dixon had entered almost exactly a year earlier, and thus it must have come as no surprise that the natives there had recollections of previous European visitors. Colnett, however, hoping to purchase furs, was surprised (and no doubt disappointed) to learn that the natives "had had two ships lately among them [which] purchased all they had, \& that the Crew and Commanders wore large caps \& were remarkably stout." 80 Apparently other ships besides the Queen Charlotte (although she could have been one of the ships refered to) had traded at Yakutat Bay, or, as anthropologist Frederica De Laguna has suggested, ${ }^{81}$ the ships may have actually been anchored somewhere in the Prince william Sound vicinity and the furs traded from Yakutat Bay through native middlemen. Colnett's account contains some tenuous clues suggesting that some of these mysterious visitors may have been Russian--possibly the men Shelikhov sent eastward in 1786. Colnett wrote:

All the European articles I saw, was a file, with Hunsberg [?82] on, \& a pair of Russian or Dutch Scissors they shew'[d] us very little Iron, but from the familiar method of receiving us [I] should suppose European visitors were common. 83

Then, shortly after their departure from Yakutat Bay, probably as the Prince of Wales sailed southward somewhere between Ocean Cape and the Situk River, Colnett describes 
another encounter with the natives:

June 9 th was dark and Cloudy wind to the E'ward \& rainy at Noon no Observation South point of Foggy Harbour [Ocean Cape] NbE 4 or 5 Leagues, toward Evening it fell little wind inclining to Calm at 10 - - the officer of the Watch Informed me a Boat was coming off with a Flag for a long time [I] took it for a Russian launch, but on drawing near [she] prov'd to be a Canoe with three sticks up as masts on two of them were tails of large birds hanging by a string \& on the middle stick a strip of skin, some few skins and pieces were bought off them, \& another soon joined us; in both were 38 [84] men women \& Children; one of the Men had his dress trim'd with Chinese money, \& also shew' [d] a piece of new striped Flannel--at Midnight they left us.85

The mention of a file with the word "Hunsberg" (or possibly "Hamburg") on it and Russian or Dutch (German?) scissors hints at a Russian source because German supplies often figured in Siberian and Aleutian exploration and trade. The likelihood that the "Chinese money" was obtained from Russian promyshlenniki is small, since Sino-Russian trade was conducted on the bais of barter exclusively. 86 Asian coins, of course, could have reached North America by other means such as a shipwrecked Japanese or Chinese vessel ${ }^{87}$ (it is unlikely that colnett could have distinguished between Chinese and Japanese coins); or through the possibility that Hanna, Meares, or Tipping might have carried "Chinese money," since they all sailed from Asian ports. A Russian source for the file, scissors, and striped flannel nevertheless seems most plausible.

Whatever the source of the "Chinese money" seen by Colnett at Yakutat Bay in 1788, this appears to be the 
earliest recorded sighting of an item that quickly became popular up and down the coast. Similar coins were reported seen among the Klallam Indians of the Strait of Juan de Fuca in 1790, the Haida in 1791 at the southernmost point of the Queen Charlotte Islands, and again in 1792 at Langara Island, northernmost of the group. 88 As an added note of interest, when Colnett returned to the Northwest Coast in 1789, "China Cash" appear in a list of trade goods he turned over to members of his crew who sailed a longboat from Mexico to Vancouver Island. 89 The "Chinese money" he saw at Yakutat Bay in 1788 very likely induced him to include Chinese copper-alloy coins (so-called "cash") among the trade goods of his second voyage, which in turn probably contributed to the swift and widespread distribution of these coins among the Northwest Coast Indians. The coins seen at Yakutat Bay, of course, preceded this period and thus clearly involved some other source.

The fur trading activity of English mariners after 1788 increasingly turned southward below Dixon Entrance, with Nootka Sound becoming the operational focus of the English trade. When Meares, for example, mounted a second expedition in 1788 he steered for Vancouver Island, and most of his activities were conducted outside of Alaskan waters. 90 No doubt, his winter experience at Prince William Sound had some influence on his decision to concentrate his efforts southward, but the disappointing discov- 
ery of Russian competitors in the North also seems to have impelled him, as well as others of his countrymen, to seek their fortunes primarily below the 55th parallel. 91

The most significant involvement of English vessels in Alaskan waters in the last decade of the 18 th century was George Vancouver's government-sponsored efforts to chart the coast in detail from Cook Inlet southward to the Spanish settlements in California. 92 For the purposes of this inquiry, however, the records of Vancouver's two visits to Alaskan waters in 1793 and 1794 add relatively little new information concerning the prevalence of nonaboriginal articles among the natives. Compared with Strange, Portlock, Dixon, Meares, and Colnett, Vancouver arrived late on the scene, and his journals testify mostly to the increasing volumn of European and Asian goods that earlier voyagers had already introduced. An attack by natives (probably Tlingits) on one of Vancouver's exploring parties in August, 1793, on Behm Canal off Clarence Strait east of Prince of Wales Island, however, revealed a new and distressing--to Europeansat least--turn in native weaponry: they were obtaining and using firearms. Vancouver pondered this incident, speculating on the reasons for the natives' agressiveness:

It was manifestly evident that they had been acquainted with civilized commerical people, by the muskets and other European commodities in their possession; and when we considered the particular behaviour of the first man who visited us, we had reason to sus- 
pect that they had been ill-treated in their traffic with white men. This Indian, by means of signs and words too expressive to be mistaken, gave us clearly to understand, that they had reason to complain of one or more muskets that they had purchased, which burst into pieces on being fired. . . These defects have not arisen from ignorance or mismanagement on the part of the Indians, but from the baseness of the metal and imperfect workmanship of the fire arms. 93

The growing importance of firearms as a commodity in the fur trade was further demonstrated in contact with other natives at Behm Canal. There, in Saptember, 1793, when Vancouver attempted to purchase some sea otter skins, the natives at first insisted on muskets and ammunition in exchange. When these were steadfastly refused, blue cloth, files, and tin kettles were finally accepted as substitutes; but "their fish and other less valuable articles, were readily parted with, for pewter spoons, looking glasses, beads, and other trinkets." 94

One final incident among the Tlingits of Behm Canal may fittingly close these observations by the English of outside influences north of Dixon Entrance. Among the visitors who came to trade

was one whose character [Vancouver wrote] we could not define. This was a young man, who seemed to differ materially from the rest in his general deportment. He was dressed in a blue jacket and trowsers, and seemed to be perfectly at his ease, particularly with respect to the pockets... he was very fond of segars [cigars], which he smoked in the Spanish fashion, discharging the fumes through his nostrils, and also of snuff... All our different kinds of provisions were perfectly familiar to this young man, who ate and drank of everything that was given him. •. His person 
had nothing of the European character in it, but from attentively observing his continance, we were inclined to suppose him a native of New Spain, who might possibly have deserted from some of the Spanish vessels employed in the examination of this coast... [But] he did not betray the least knowledge of the Spanish tongue. 95

At least two incidents involving deserters from Spanish ships are known. Two apprentice seamen deserted in June, 1775, while the Hezeta-Bodega expedition was at Trinidad Harbor in northern California; and again two men left the Arteaga-Bodega expedition at Bucareli Bay in June, 1779.96 All but one of these persons, however, were returned to their ships, and the one apparently successful desertion was at Trinidid Harbor, some $1700 \mathrm{~km}$. south of Behm Canal and 18 years earlier than Vancouver's visit there. While these cases almost certainly have no connection with the individual Vancouver saw at Behm Canal, they do support the plausibility that he may indeed have been a deserter. Such desertions must have occurred at other times, and probably not only from Spanish ships. What is more important, such persons would sometimes have been able to supply their native hosts with valuable information or skill, augmenting the flow of material goods into native hands. 
1 Accounts of Cook's third expedition are in J. C. Beaglehole, The Journals of Captain James Cook, I I .

2Ibid., III, 341. This was not described by Cook explicitly as an act of possession, although two weeks later a bottle with similar contents was buried at Cook Inlet to "take possession of the Country and River in his Majestys name" (see ibid., III, pt. 1, 368).

3 Ibid., III, pt. 1, 342.

${ }^{4}$ First Lieutenant John Gore, aboard the Resolution, gives the name of this point as Cape Hold with Hope, and so it appears on the expedition's map of Prince William Sound (see ibid., III, pt. 1, 343, n. 1).

5 Ibid., III, pt. 1, 344. The "white dres" seems to refer to something akin to the "white sheet" that the natives at Los Remedios used to greet Bodega in 1775.

${ }^{6}$ Ibid., III, pt. $1,346$.
${ }^{7}$ Ibid., III, pt. $1,350$.
${ }^{8}$ Ibid., III, pt. $2,1418$.
${ }^{9}$ Ibid., III, pt. $2,1418$.

10 Arthur Woodward, Denominators of the Fur Trade, $p$. 33; also see $P .42$ for illustrations of light blue opaque beads from Kodiak Island, Alaska, that resemble the beads described by Cook and $K i n g$. It has also been suggested that these so-called "Cook-type" blue glass beads may have been of Chinese manufacture (see Frederica De Laguna, Chugach Prehistory, The Archaeology of Prince William Sound, Alaska, P. 62).

${ }^{11}$ It is fair to observe that the beads the Arteaga expedition saw among the Prince William Sound inhabitants in 1779 are attributable only in part to Cook's visit.

12 Beaglehole, The Journals of Captain James Cook, II I, pt. 1, 346.

$$
\begin{aligned}
& 13 \text { Ibid., III, pt. } 1,346 . \\
& 14 \text { Ibid., III, pt. } 1,368 . \\
& 15 \text { Ibid., III, pt. } 1,371 .
\end{aligned}
$$


16 Ibid., III, pt. 1, 383.

17 Ibid., III, pt. $1,383$.

${ }^{18}$ Ibid., III, pt. 1, 384, n. 1. As Bayle says, the note was a iasak receipt. According to Peter Pallas it was one of a number of such receipts distributed by Potop Zaikov (see Masterson and Brower, Bering's Successors, 17451780, P. 89). The surmise that Unga Island was the Iimit of Russian trading, however, was wrong. Stepan Glotov had reached Kodiak Island $400 \mathrm{~km}$. to the east as early as 1763 (Coxe, Russian Discoveries, $p .108$ ), and Dmitrii Bragin had been there as recently as the summer of 1776 (Masterson and Brower, Bering's Successors, p. 71).

19 Beaglehole, The Journals of Captain James Cook, II I, pt. 1, 386 .

$$
\begin{aligned}
& { }^{20} \text { Ibid., III, pt. } 1,403 . \\
& 21 \text { Ibid., III, pt. } 1,399-400,402 \text {. The bottle, ac- }
\end{aligned}
$$
cording to Cook, contained a piece of paper with the ships' names and the name given the promontory where the bottle was left, Cape Newenham. No mention, however, is made of silver coins as was the case at Kayak Island and Point Possession in Cook Inlet.

$$
\begin{aligned}
& 22 \text { Ibid., III, pt. } 1,409 . \\
& 23 \text { Ibid., III, pt. } 1,411 . \\
& 24 \text { Although a branch of the Bering Sea Eskimos inha- }
\end{aligned}
$$
bited the Asiatic side of Bering Strait, Cook's description of the natives at Lavrentia Bay strongly suggests they were Chukchi, a Mongoloid people with affiliations more Siberian than American (see ibid., III, pt. 1, 412, n. 1; and Bandi, Eskimo Prehistory, P. 3).

${ }^{25}$ Beaglehole, The Journals of Captain James Cook, II , pt. 1, 411.

${ }^{26}$ This is the same term used to describe the spears at Prince William Sound.

$$
\begin{aligned}
& 27 \text { Ibid., III, pt. 1, } 431 . \\
& 28 \text { Ibid., III, pt. 1,410, } 431 . \\
& 29 \text { Ibid., III, pt. 1, } 437 . \\
& { }^{30} \text { Ibid., III, pt. 1, } 438 \text {. }
\end{aligned}
$$


${ }^{31}$ Cook says his name was Derramoushk, although in other accounts it is spelled in differing ways such as Yearmosk, Yarmousk, or Yamoska (see ibid., III, pt. 1, 448, n. 5). He also is referred to as Perpheela by John Ledyard (Journal of Captain Cook's Last Voyage, $P .93, n .1$ ) in his account of these events.

32 Beaglehole, The Journals of Captain James Cook, III, pt. 1,448 .

33 Ibid., III, pt. 1,449 .
34 Ledyard's account of this mission in his Journal of Captain Cook's Last Voyage, PP. 91-100, says he was gone four days. Cook's mention of this incident has Ledyard departing on October 8 and returning October 10 (see Beaglehole, The Journals of Captain James Cook, III, pt. 1, 448449)?

${ }^{35}$ Cook mentions that "one of these Men said he was [on] the American Voyage with Behring" (ibid., III, pt. 1, 449). A Grigori Izmailov does in fact appear in the roster of soldiers who were aboard the Sv. Petr in 1741 (see Golder, Bering's Voyages, I, 235). Gerassim Izmailov's patronymic, Grigorovich, suggests that he may have been the son of the soldier who sailed 37 years earlier with Bering. There is little doubt that he was the same Izmailov sent by Delarov to explore Yakutat Bay in 1788 (see Tikhmenev, A History of the Russian-American Company, D. 24; and $P$. 45 of this study).

${ }^{36}$ Beaglehole, The Journals of Captain James Cook, III, pt. 1, 455-456.

37 When Cook left Cook Inlet he failed to sight the passage (today called Shelikof Strait) that separates Kodiak Island from the mainland. Thus he assumed that the coastline he had passed east of the Shumagin Islands was all part of the mainland, not suspecting that some of it was in fact a large island (Kodiak).

$$
\begin{aligned}
& { }^{38} \text { Beaglehole, III, pt. } 1,461 . \\
& { }^{39} \text { Ibid., III, pt. } 1,461 . \\
& 40 \text { The term "brig" or "brigantine" refers to a two- }
\end{aligned}
$$
masted vessel with the foremast square-rigged and the mainmast carying a fore-and-aft mainsail and square-rigged topsails (see Landström, Sailing Ships, PP. 155-156).

41 She may have sailed under Portuguese colors because 
it is possible Hanna was unlicensed by the East India Company to conduct trade between North America and China as was required of British subjects (see Greenhow, History of Oregon and California, pp. 164-165). Hanna's Ms journal in the British Columbia Provincial Archives covers only the portion of the voyage from Macao to Nootka Sound (see F. W. Howay, "A List of Trading Vessels in the Maritime Fur Trade," Transactions of the Royal Society of Canada, 3rd. series, 24, sec. $2(1930), \mathrm{p} \cdot 113)$. John Meares, Voyage Made in the Years 1788 and $1789 \cdot \cdot$. [and] A Voyane performed in 1786, from Bengal, in the Ship Nootha $:$., p. Iii), who saw Hanna's complete journal, says that Hanna "proceeded to the Northward [from Nootka] where he discovered several sounds, islands, and harbours."

42 Accounts of this expedition are in Nathanial Portlock, A Voyage Round the World, and George Dixon (William Beresford), A voyage Round the World. The expedition was organized by the King George's Sound Company under license of the South Sea Company, with arrangements to sell the furs in Canton through agents of the East India Company (see Greenhow, History of Oregon and California, pp. 168169).

${ }^{43}$ Probably an inlet on Kachemak Bay. Portlock called it Coal Harbour because of finding coal there.

${ }^{44}$ portlock, A Voyage Round the World, Pp. 98-99. 45 Ibid., p. 99.

${ }^{46}$ Shelikhov says that sometime shortly after May 19 (0.S.), 1786, a fort was built on Kenai Bay (Cook Inlet) as part of the effort to end the Kenai rebeliion. See Shelikhov, Rossiiskogo kuptsa Grigoriia Shelikova stranstuovaniia, trans. MS., $P_{0} 18 ;$ and $p_{0} 44$ of this study.

47 Portlock, Voyage, P. 115; and Dixon, Voyage, P. 68. 48 portlock, P. 121 .

${ }^{49}$ Accounts of this expedition, which sailed under license of the East India Company, are given in James Strange, Journal and Narrative of the Commercial Expedition from Bombay to the Northwest Coast of America; and Alexander Walker, $\frac{A_{n}}{A_{c} c o u n t} \frac{\text { of }_{1}}{17}$ a Voyage to the North West Coast of America in 1785 and $178 \overline{6}$.

50 In finding that the Nootkan natives were disappointingly indifferent to trade items such as knives, chisels, axes, or swords, Strange remembered that he had 
a large quantity of cymbals, which he "conceived would be no bad substitute for their Shells" used to keep time in singing. The cymbals proved to be extremely popular. See Strange, Journal and Narrative, pp. 84-85.

$$
\begin{aligned}
& 51 \text { Ibid., } P .103 . \\
& 52 \text { Ibid., } P .113 . \\
& 53 \text { The term "snow" refers to a two-masted vessels }
\end{aligned}
$$
similar to a brigantine, but with a gaffsail set on a spar (the "snowmast") aft of the mainmast (see Landström, Sailing Ships, Pp. 154-155).

${ }^{54}$ An account of the Nootka's voyage is in John Meares, Voyages. No account of Tipping's voyage in the Sea Otter is extant, since the ship was lost without a trace sometime after she departed Prince William Sound. Both ships sailed under the East India Company flag, but they apparently did not have proper licenses to do so. See Warren Cook, Flood Tide of Empire, P. 137.

55 When George Dixon came upon the Nootka in May, 1787, he claimed she was anchored in another nearby cove, thus it is uncertain exactly where Meares anchored (see Dixon, Voyage, PP. 153-154). There is also some question as to why Tipping left Prince William Sound without waiting for Meares to arrive, since that was, according to Meares' account (Voyages, p. xii), their agreed upon rendezvous. One possible explanation is that since he was unlicensed by both the East India and the South Sea companies, the presence of Strange's licensed expedition caused Tipping to make a hasty departure.

56 Meares, Voyages, $P_{0}$ xii. This evidence could have been left by Strange, Tipping, or for that matter the expeditions Shelikhov dispatched in 1785 or 1786 .

57 George Dixon, Voyage, p. 151, suggested that more than scurvy was responsible for this high mortality rate: "on our enquiring whether the scurvy, unattended with any other complaint, had made such fatal havock amongst the people belonging to the Nootka, we were informed, that a free and unrestrained use of spirits had been indescriminately allowed them during the extreme cold weather, which they had drank to such excess about Christmas, that numbers of them kept their hammocks for a fortnight together; add to this, their liquor was of a very pernicious kind so that there is reason to suppose its effects, when drank to such an extreme, were not less fatal than the scurvy itself." 
58 Meares, Voyages, p. xxxiv.

${ }^{59}$ Ibid., P. xxiv, and notes and documents ff. Portlock's correct but cool manner toward Meares, in which he conditioned the aid he rendered on an agreement that Meares would depart the coast forthwith, was no doubt because he saw him as a trading rival, and an unlicensed one at that.

60 Dixon, Voyage, p. 168.

${ }^{61}$ La Pérouse, Voyage, I, 360-361.

62 Anthropologist Frederica De Laguna has suggested that the reason Dixon found so few furs at Yakutat Bay may have been because some interprising native middlemen had already purchased them for resale to Portlock at Prince William Sound. She believed the Eyak Indians were likely the middlemen between the Chugach Eskimos and the Yakutat Tlingits. If this interpretation is correct, it would mean that European or Asian trade goods flowed eastward and southward while the furs they were used to purchase moved in the opposite direction; and that no prior direct contact with outsiders need be posited to account for the non-aboriginal articles Dixon saw among the Yakutats (see De Laguna, Under Mount St. Elias, I, 126). It is possible, however, that some of the men Shelikhov sent from Kodiak to explore eastward reached Yakutat Bay sometime in 1786 (see p. 44 of this study).

63 Dixon, Voyage, P. 180.

64 Ibid., P. 182 .

65 Ibid., Pp. 182-183. The Queen Charlotte was a

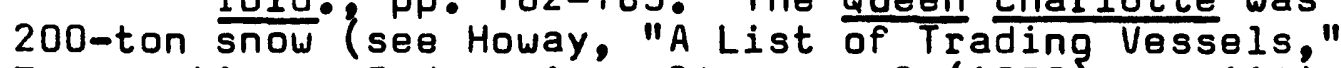
Transactions, 3rd series, 24 , sec. 2 (1930), p. 114).

${ }^{66}$ Bodega's Sonora was a two-masted goleta or schooner of not much over 30 tons (see Malcolm H. Kenyon, "Naval Construction and Repair at San Blas, Mexico, 1767-1797," P. 124 ).

67La Pérouse, Voyage, I, 417-418. The term "frigate" in the 18th century was a generic name for a variety of fast-sailing warships (see Landstöm, Sailing Ships, Pp. pp. 150-152).

${ }^{68}$ This anchorage, at $57^{\circ} 43^{\prime} \mathrm{N}$., is located about 18 $\mathrm{km}$. southeat of the entrance to Lisianski Strait, where Chirikov's 15 men were lost in 1741. 
${ }^{69}$ Portlock, Voyage, p. 266.

70 Ibid., p. 266. He was no doubt correct in concluding that these unysual beads and the carpenter's adze had been left by La Pérouse in 1786. It is possible that the letter "B" refers to the city of Brest, where the French expedition was outfitted. Fifty carpenter's adzes are in fact listed in the expedition's inventory of "goods and merchandize. - for the purpose of barter and making presents" (see La Pérouse, Voyage, I, 182).

$$
\begin{aligned}
& { }^{71} \text { Portlock, Voyage, P. } 266 . \\
& 72 \text { Ibid., P. } 266 .
\end{aligned}
$$

${ }^{73}$ Dixon's anchorage at Yakutat Bay was over $330 \mathrm{~km}$. southwest of Portlock Harbor.

74 Hanna'a Sea Otter (or Harmon) was a two-masted brig, and Tipping's ship, being a snow, would also have had two masts. Russian ships operating in Alaskan waters in the 18th century were commonly galliots, brigs, or hookers, all of which were two-masted. There is a remote possibility that the story Portlock heard about the loss of a ship's boat was a recollection of the tragedy that overtook Chirikov's two boats in 1741 while off Lisianski Strait. That location is just $18 \mathrm{~km}$. northwest of Portlock Harbor. Chirikov lost an 11-man longboat and a smaller boat with four hands aboard. While the likelihood that an event 46 years earlier would still be remembered may seem small, and the number of lost men does not jibe exactly with the account given Portlock, the possibility cannot be entirely excluded. As for Spanish ships, Bodega's two-masted Sonora was in this vicinity in 1775, but she had no small boat; and there is no mention of aboat being lost in the records of the 1779 Arteaga expedition.

$$
\begin{aligned}
& 75 \text { Portlock, Voyage, P. } 282 . \\
& 76 \text { Ibid., P. } 282
\end{aligned}
$$

77 A dozen scarlet coats are listed among La Pérouse's inventory of trade items (see La Pérouse, Voyage, I, 184).

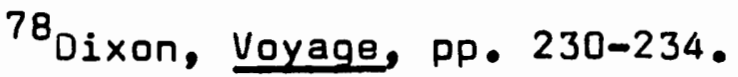

${ }^{79}$ Colnett's account of this expedition is in his MS. "Journal of the 'Prince of Wales', October 16, 1786 - November 7, 1788," in the Public Record Office, London, Adm. 55/146. A microfilm copy is also in the University of Washington Library, Seattle. Extracts from this MS. were published in De Laguna, Under Mount St. Elias, I, 128- 
132, as part of a summary description of Colnett's voyage. The MS. Journal is unpaginated, so that references to it that follow use the page nembers of De Laguna's published extracts. Colnett's Journal is largely undivided into paragraphs, and its sentences rarely begin with capital letters or end with periods. While De Laguna emended the text, the original punctuation has been retained in the following quotations from the Colnett MS.

${ }^{80}$ De Laguna, I, 130; and Colnett, "Journal of the "Prince of Wales."

${ }^{81}$ De Laguna, I, 126.

${ }^{82}$ De Laguna's published version has "Hunsberg[?]," but in consulting the Colnett MS. (on microfilm) this writer believes that "Hamburg" is also a possible reading.

${ }^{83}$ De Laguna, I, 130; and Colnett, "Journal of the 'Prince of Wales'."

${ }^{84}$ De Laguna's published version has "30", but in consulting the Colnett MS. (on microfilm) this writer found the number to be "38".

${ }^{85} \mathrm{De}$ Laguna, I, 131; and Colnett, "Journal of the 'Prince of Wales'." The passage quoted here is directly from the MS. De Laguna's extract includes only the passages "the officer of the watch - . a strip of skin," and "Some fow skins... they loft us."

${ }^{86}$ Trade between the Russians and Chinese at the Mongol border town of Kiakta was by law conducted solely on the basis of barter, so surrency could not legally cross the border (see Coxe, Russian Discoveries, pp. 232, 240242).

${ }^{87}$ See Brooks, "Report of Japanese Vessels Wrecked in the North Pacific Ocean."

${ }^{88}$ See Henry R. Wagner, Spanish Explorations in the Strait of Juan de Fuca, P. 109; John Hoskins, "Narrative of the Second Voyage of the 'Columbia'," Voyages of the "Columbia" to the Northwest Coast, 1787-1790, 1790-1793, p. 205; and Wagner and Newcomb, "The Journal of Don Jacinto Caamaño," P. 219.

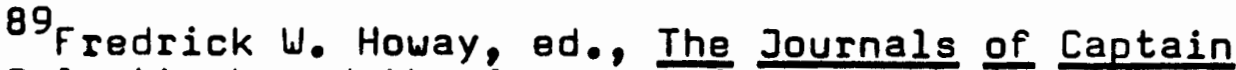
James Colnett aboard the Argonaut from April 26, 1789 to November 3, 1791, P. 179. 
90 His associate, William Douglas, however, sailing separately in the ship Iphigenia Nubiana, followed a northerly course and traded on the southern and southeastern Alaskan coasts before rendezvousing with Meares, aboard the ship Felice Adventurer, at Nootka Sound. Both ships sailed under Portuguese colors out of Macao, ostensibly to avoid seizure because of their unlicensed status (as British subjects) to engage in the fur trade. Accounts of this expedition are in Meares, Voyages (also see Greenhow, History of Oregon and California, pp. 172-173).

91 Despite Cook's formal claims of British sovereignty at Cook Inlet and Bristol Bay in 1778, the priority of Russia's claim southward to 5440 'N. was well founded because of the discoveries of Bering and Chirikov in 1741 and the presence of Russian settlements that, by the late 1790s, included outposts at Yakutat and Sitka.

92 An account of this expedition is in George Vancouver, A Voyage of Discovery to the North Pacific Ocean and Round the World.

$$
\begin{aligned}
& 93 \text { Ibid., IV, } 179 . \\
& 94 \text { Ibid., IV, 229-230. } \\
& 95 \text { Ibid., IV, 230-231. Erna Gunther, Indian Life on }
\end{aligned}
$$
the Northwest Coast of America, p. 168, speculated that this person may have been a Filipino cabin boy who had deserted some European ship.

${ }^{96}$ See Hezeta, "Diario •. 1775," entries for June 14, 15, and 16, 1775; and Bodega y Quadra, "Second Expedition . - 1779," pp. 36-37. 


\section{CHAPTER VI}

FRENCH VOYAGES

Ships of French nationality were not seen in the waters off northwestern North America until 1786, and altogether their numbers were not large compared with other nationalities. ${ }^{1}$ Yet, the first expedition launched by France to this part of the world would uncover valuable ethnographic information (primarily from one location), and a subsequent french fur trading venture would record, among other things, some especially interesting clues relevant to this inquiry.

It was June 23, 1786, when the two vessels Boussole and Astrolabe, under the overall command of Jean François Galaup de La Pérouse, came within sight of Mount St. Elias in southeastern Alaska. 2 They had been sent by the French government to explore and survey the Pacific where previous expeditions had left gaps, so their course now took them southeastward along an essentially unexplored stretch of coast that had only been glimpsed at a distance by cook in 1778. Three days later, while in latitude $59^{\circ} 41^{\prime}$ N., they came upon a wooded point that seemed to guard "the mouth of a large river, if not a channel." 3 This was al- 
most certainly Ocean Cape at the south entrance to Yakutat Bay. Two boats were sent ashore, but their officers concluded "that there was neither channel nor river," and that the opening was merely an exposed "large semicircular bay." 4 La Pérouse, acting on this report, decided to seek another anchorage, thus missing an opportunity to explore and take haven in what is in fact a splendid harbor.

Continuing southeastward along the coast, the expedition next came upon a narrow opening in the coast at latitude $58^{\circ} 37^{\prime} \mathrm{N}$. Boats were again dispatched to examine this new entrance and the harbor behind it. This time a highly favorable report was forthcoming, which "determined me," wrote La Pérouse, "to steer for the passage." 5 This entrance proved, however, to be deceptively treacherous, the reporting officers having seriously misjudged its dangers. La Pérouse's ships managed to enter, but only after narrowly escaping destruction in the grips of powerful tidal currents. 6 They called this seductive harbor port de Francais, although today it bears the name Lituya Bay. According to La Pérouse's account, even before they entered the harbor, natives were seen "who made signs of friendship, by displaying and waving white mantles, and different skins." 7 They also saw canoes with their native occupants fishing in the placid waters within the bay. These were only a sampling of what the french would encounter during more than a month's stay at Lituya. Canoes 
eventually swarmed around the two french ships once they were anchored within the harbor, and La Pérouse described the ensuing trade between his men and the natives:

To our great surprise they appeared well accustomed to traffic, and bargaining with as much skill as any tradesman of Europe. Of all our articles of trade, they appeared to have no great desire for any thing but iron: they accepted indeed a few beads; but these served rather to conclude a bargain, than to form the basis of it. We at length prevailed on them to take pewter pots and plates: yet these had only a transient success, iron prevailing over every thing. They are not unacquainted with this metal. Every one had a dagger of it suspended from the neck, not unlike the criss of the Malays, except that the handle was different, being nothing more than an elongation of the blade, rounded, and without edge. This weapon had a sheath of tanned leather, and appeared to be their most valued moveable. As we examined these daggers very attentively, they informed us by signs, that they made use of them only against the bears and other wild beasts. Some were of copper, but they did not appear to give a preference to these. This metal is pretty common among them: they use it chiefly for collars, bracelets, and various other ornaments; and they also point their arrows with it. 8

These were unexpected findings, for La Pérouse had been convinced that "this port was never seen by any [European] navigator." 9 He considered four possible sources from which such articles might have been obtained: "from the Russians, from the servants of the Hudson's Bay company, from American merchants travelling into the interior parts of the country, or from the Spaniards."10 Eventually, he concluded that the Russians were the more likely source, but through the indirect medium of a native trading system that linked Lituya Bay with the coast northwestward. 
It was in observing the movements of the native canoes that La Pérouse began to suspect that Lituya Bay was in fact a waystation for traders sailing along the coast. ${ }^{11}$ La Pérouse wrote:

Every day we saw fresh canoes enter the bay; and every day whole villages departed, and gave place to others. These Indians seemed to have considerable dread of the passage, and never ventured to approach it, unless at the slack water of flood or ebb. By the help of our glasses we distinctly perceived, that, when they were between the two points, the chief, or at least the principal Indian, arose, stretched out his arms towards the sun, to which he appeared to address a prayer, while the rest paddled away with all their strength. In the course of our inquires respecting this custom, we learned, that seven very large canoes had lately been lost in this passage, while an eighth escaped. This the Indians who were saved consecrated to their god, or to the memory of their comrades. We saw it by the side of a morai [sepulcher], which no doubt contained the ashes of some who were shipwrecked.12

In examining this surviving canoe, the french discovered that, unlike most of the canoes they had seen, this one had not been hollowed from a 109 , but instead was constructed of a wood frame covered by seal-skin. This type of craft, closely associated with the Aleut-Eskimo peoples, suggested that trade connections must have reached at least to "the neighbourhood of the islands of Shumagin, and of the [Kenai] peninsula explored by Cook."13 The natives" frequent comings and goings and their large supplies of sea otter pelts served to strengthen the surmise that they were engaged in some sort of coastal trade, and since that trade apparently extended northward a considerable distance 
it was reasonable to assume that iron, copper, or non-aboriginal articles had come from that direction. 14

After briefly anchoring near the entrance of this bay, the two French ships moved to an anchorage behind a large island farther inside the bay, where an observatory was set up ashore. One of the native chiefs thereupon offered to sell me [La Pérouse] the island, on which our observatory was erected; tacitly reserving, no doubt, to himself and the other Indians, the right of robbing us upon it. It was more than questionable, whether this chief were proprietor of a single foot of land.. - yet, as many of the savages were witness to the bargain. I had a right to suppose that it was sanctioned by their assent; and accordingly I accepted the offer. - aware, however, that many tribunals would find a flaw in the contract . - Be this as it might, I gave him several yards of red cloth, hatchets, adzes, bar iron, and nails - . The bargain being thus concluded, and the purchase money paid, I sent to take possession of the island with the usual formalities, and buried at the foot of a rock several bronze medals, which had been struck before our departure from France, with a bottlo containing an inscription recording our claim. 15

As if to confirm La Perouse's remark about the natives' purloining motives, two officers who were stationed ashore at the observatory had their tent entered while they were asleep. The natives "took away a silver-mounted musket, and the clothes of the two officers, which they had taken the precaution to place under their pillow without being perceived by a guard of twelve men, or even awakening the officers." ${ }^{16}$ This incident would have been trivial--even humorous--had it not been that the expedition's astronomical observations also disappeared in the 
theft. It has significance for this inquiry also, in that it may explain the sightings in 1787 of a white shirt by Dixon at Sitka Sound and two scarlet coats by Portlock on the west coast of Chichagof Island. If this small pilfering episode was in fact the source of these articles, it would indicate that such items had moved between 75 and $150 \mathrm{~km}$. southward in a year.

On July 13, two boats with 21 officers and men were swamped by powerful tidal currents as they, in company with a third boat, were surveying the treacherous entrance to Lituya Bay. This unexpected tragedy not only exacted a high toll in lives (all 21 were drowned), but it forced La Pérouse to remain in this harbor well beyond his intended stay. It was not until July 30, 1786, that the Boussole and Astolabe finally departed, after fruitlessly searching for survivors of the accident. This delay severely curtailed the expedition's investigations on the coast southward, and thus La Pérouse's voyage from Lituya Bay to Monterey produced little additional ethnographic data. Five years after La Pérouse's visit to Lituya Bay a second French expedition appeared in southeastern Alaskan waters. This enterprise, unlike its predecessor, was privately financed and motivated primarily by the commercial possibilities of the fur trade. It consisted of one ship, the Solide commanded by Étienne Marchand, which sailed out of Marseilles reaching the Northwest Coast by 
way of Cape Horn and the Marquesas Islands. ${ }^{17}$ The ship entered a large bay (at $57^{\circ} \mathrm{N}$. latitude) early in August, 1791, that the French later heard the natives call Tchinkitânay, and which Marchand believed was the same location Dixon had named Norfolk Sound. This was also the place Bodega had discovered in 1775, naming it Guadalupe, and to which the name Sitka Sound is applied today.

The French located the cove in which Dixon had anchored in 1787 (about $6.5 \mathrm{~km}$. north of Shoals Point on the west side of Sitka Sound), rating it a very hospitable anchorage with fresh water nearby. What it lacked unfortunately was the most essential ingredient for a successful fur trading venture: native inhabitants willing and eager to trade. About the time Marchand prepared to weigh anchor, however, several canoes appeared from the east side of the sound and this small cove quickly became the scene of a brisk trade.

On the following day a larger flotilla, numbering 15 canoes with between 130 and 140 natives (Sitka Tlingits), swarmed about the Solide anxious to do business after they had completed their customary songs. Since Dixon's visit in 1787, when "toes" (iron chisels) were "the article of traffic held in the first estimation," native tastes had changed. C. P. Claret Fleurieu, author of the principal published account of the voyage, explains:

The articles which the natives preferred in exchange 
were basins, and especially those made of copper, stew-pans, tin sauce-pans, iron pots, daggers, lances, halberts, pikes, and sabres: they set little value on hatchets, saws, two-handled knives, hammers, nails, and other tools or instruments. But our voyagers were ignorant that the articles which, in trafficing with them, obtain the greatest favor, are European clothes of different sorts.18

Such articles were not among the Solide's regular trade goods, and thus Marchand's only recourse was to dip into the crew's own supply of spare clothing. Fleurieu, in assuring his readers that the crew did not suffer unduly as a result, continues:

Clothes were the only effects for which it was possible to obtain the beautiful otter-skins of the first quality. Small knives, coloured glass-beads, rings and metal buttons, and all those European toys, after which, in general, the islanders of the GREAT OCEAN appear so anxious, were hardly accepted as a free gift. . . it will be seen that they begin to be europeanised. They are already partly dressed in the European fashion; most of them had cloth jackets, kersy trowsers, [and] shirts. . . Almost all the garments were of English manufacture; but there was reason to presume that some vessel belonging to the UNITED STATES might likewise have traded in TCHINKITANAY Bay or in its vicinity, because there were recognized two copper coins of the province of MASSACHUSETTS which a young man wore as ear-pendants. 19

The English clothing, the apparent high value placed on it, and the two American coins ${ }^{20}$ seen by Marchand at Sitka Sound are matters of considerable interest. While there was no shortage of English and American ships on the coast between 1788 and 1791, only two (both English) are known to have definitely been at or near Sitka Sound, and neither of them appears to have engaged in trade there. 21 
The English clothing Marchand saw at Sitka thus must have reached there primarily through native trade channels from areas to the south of Dixon Entrance where the main English trading activities were centered. As for the two Massachusetts coins, the nearest any American ship is known to have come to Sitka Sound (before Marchand's visit in August, 1791) was the voyage in May, 1789, of the sloop Lady Washington, captained by Robert Gray, to the vicinity of Bucareli Bay (about $250 \mathrm{~km}$. south of Sitka). 22 while returning south Gray engaged in extensive trade with "a vast number of Natives men Women and Children" at Langara Island on the south side of Dixon Entrance in June, 1789.23 It is quite possible that the two coins Marchand saw at Sitka two years later entered the native trade network at that point, because, according to Robert Greenhow, "they [the Lady Washington and her consort the Columbia Rediviva] • - carried out, for distribution at such places as they might visit, a number of small copper coins, then recently issued by the state of Massachusetts..." 24 In any event, it seems most probable that these coins as well as the English clothing at Sitka Sound must have been traded northward over considerable distances (as much as $400 \mathrm{~km}$. or more) through the medium of native exchange.

Marchand moved south out of Alaskan waters and traded no further with natives north of Dixon Entrance. He did, however, stop at Langara Island on the south shore of the 
entrance, where the natives had been trading extensively with Europeans since 1774, when Juan Pérez had first stopped there. 25 fleurieu left a graphic description of the curious mixture of material goods these people possessed

17 years after their first European visit:

here are seen confounded with wooden vessels and spoons of horn or of whalebone, peculiar to the country, iron pots and kettles, stew-pans, fryingpans, boilers, tin basins, and other household utensils, with which the Europeans have furnished the Americans, and the use of which is become as familiar to them as to ourselves. There were also seen sheets of copper, large pieces of bar iron, hatchets, adzes, joiner's chisels, plane-irons, daggers, and lances, the whole of English manufac- 26 ture, mingled and confounded with American lances. 26

The french also noticed the beginnings of a keen interest in firearms among the natives, and, just as Vancouver would later discover, the quality of the ones they had obtained was less than first-rate:

The master of the habitation [probably Cania of the village named Kuista on Parry Passage] also possessed for his own particular use four muskets and half a pound of powder; but, fortunately for him, and perhaps others, he neither had balls nor lead: I say fortunately: in fact, on the one hand, the French had an opportunity of seeing, in the trials which he made with a little powder, because he was very sparing of it, that he used this weapon very aukwardly; and, on the other, it appeared, that the arms which he had received in the course of barter with the English were so bad a quality, that not one of them would have been able to stand the most common charge, if this charge had been fired with ball or even shot. It appears that he was not acquainted with the use of either; for, although he had renewed several times, but in vain, his entreaties in order to obtain from the French powder and myskets, he never asked them either for lead or ball.27

While such detailed observations help to fill in the 
picture of the changes that were sweeping Northwest Coast Indian material culture in areas where contact with Europeans had been prolonged, the more significant contribution of the voyages of La Pérouse and Marchand may in fact be the light they shed on the extent and nature of the native trading system operating on the coast in the areas less frequented by Europeans. By visiting places like Lituya Bay and Sitka Sound, which until late in the 18th century were seldom visited by Europeans, lying on the long stretch of coast between Prince William Sound (a center of Russian and English activity) and the Queen Charlotte Islands (a center of English and American activity), the French expeditions seem to have caught some important glimpses of the mechanism that transported furs in one direction and the odd assortment of exogenous goods that purchased them and moved in the opposite direction. 
${ }^{1}$ Besides the two vessels of the 1786 expedition, only three other French ships are believed to have sailed off the Northwest Coast before 1800, one of which flew the American flag (see Howay, "A List of Trading Vessels in the Maritime Fur Trade," Transactions, 3rd series, 24 , sec. 2, $(1930)$, pp. $122,126,128,130)$.

${ }^{2}$ An account of this voyage, up to January, 1788 , when the Boussole and Astrolabe reached Botony Bay, Australia, is in La Pérouse, Voyane. Also see John Dunmore, French Explorers in the Pacific, I, 250-282. The events of the voyage after they departed Botony Bay, however, are known only from indirect or fragmentary evidence, since La Pérouse and his entire expedition vanished in the South Pacific eastward of Australia. Both ships probably were wrecked southeast of the Solomon Islands at an island called Vanikoro in the Santa Cruz group. The search for La Pérouse's missing ships and their probable fate is discussed in Dunmore, I, 283-341.

$$
\begin{aligned}
& { }^{3} \text { La Pérouse, Voyage, I, } 360 . \\
& { }^{4} \text { Ibid., I, } 360 . \\
& 5 \text { Ibid., I, } 365 .
\end{aligned}
$$

6 "During the thirty years that I have followed the sea," La Pérouse wrote, "I never saw two vessels so near being lost; and to have experienced such an event at the verge of the world would have enhanced our misfortune" (ibid., I, 367).

$$
\begin{aligned}
& { }^{7 \text { Ibid., I, } 365 .} \\
& { }^{8} \text { Ibid., I, } 369 . \\
& { }^{9} \text { Ibid., I, } 366 . \\
& { }^{10} \text { Ibid., I, } 370 .
\end{aligned}
$$

11 when Colnett was at Yakutat Bay in 1788, he came to a similar conclusion about the locality. He believed that the 200 or so natives he saw there actually resided "farther to the Southward and Eastward and [they are] only here at certain seasons of the year to hunt and fish, and trade, we learnt [he adds] of the natives here \& at Prince William Sound that they traded with each other" (see De Laguna, Under Mount St. Elias, I, 130; and Colnett MS. "Journal"). 
13 Ibid., I, 407.

${ }^{14}$ The correctness of La Pérouse's conjecture has also been confirmed by information that George T. Emmons obtainin 1886 from Cowee, a chief living on Gastineaux Channel (near Juneau). This native informant told Emmons of an oral tradition describing a summer trading expedition undertaken from a Tlingit village on Icy Strait that set out to reach Yakutat Bay. It stopped at Lituya Bay en route, where, according to cowee, four canoes and their occupants were lost attempting to enter the bay. While the survivors were mourning their lost companions they witnessed the appearance of two large vessels that must have been La Pérouse's Boussole and Astrolabe (see G. T. Emmons, "Native Account of the Meeting Between La Pérouse and the Tlingit," American Anthropologist, N.S., 13 (1911), PP. 294-298).

${ }^{15}$ La Pérouse, Voyage, I, 375.

16 Ibid., I, 372 .

17 An account of this voyage is in Étienne Marchand (c. P. Claret Fleurieu), A Voyage Round the World. The expedition was outfitted by the Marseilles firm of J. \& $D$. Baux. The idea for the voyage seems to have sprung from a chance meeting between Marchand and Nathanial Portlock at St. Helena in 1788 when the latter was returning home from his Northwest Coast venture (see Dunmore, French Explorers, I, 343).

$18_{\text {Marchand, Voyage, I, } 284 .}$
19 Ibid., I, 284-285.

20 These coins probably were of a type issued by the state of Massachusetts in cent and half-cent denominations in 1787 and 1788. The obverse bore a standing Indian and the word "Commonwealth"; the reverse featured a spread eagle, the date below, and the word "Massachusetts" above. The so-called Massachusetts Cents were issued at a mint chartered by the Massachusetts General Court on October 17, 1786. The venture proved unprofitable, and the mint was closed early in 1789 (see R. S. Yeoman, A Guide Book of United States Coins, pp. 31-32).

21 These were James Colnett's Prince of Wales and William Douglas' Iphiqenia Nubiana. Douglas was Meares' associate in his second expedition (1788). An account of the Iphigenia's voyage south from Prince William Sound to Nootka is in Meares, Voyaqes, pp. 317-333, in which there 
is mention of giving a native at Cross Sound (about $150 \mathrm{~km}$. north of sitka) "a jacket, a pair of trowsers, and an hat" (p. 323). Otherwise there is no indication that clothing was a major article of trade.

22 On May 28, 1789, the Lady Washington reached a reported latitude of $55^{\circ} 43^{\prime} \mathrm{N}$., which is somewhat less than $200 \mathrm{~km}$. south of Sitka. She was, however, under sail then, and there is no indication that the Washington engaged in trade with the natives at that latitude. The ship had previously (May 23) run on some rocks in a cove in or near Bucareli Bay (between latitude 55010' and 55030' N.), but no trade was mentioned then either (see F. W. Howay, Voyages of the "Columbia" to the Northwest Coast, 1787-1790 and $1790-1793, \mathrm{PP} \cdot 94-95)$.

23 Robert Haswell, the Washington's second officer, wrote that "of those people were purchaced to the amount of two hundred skins in a very fue moments for one chizle each" (ses ibid., p. 96).

${ }^{24}$ Greenhow, History of Oregon and California, p. 180. In addition to these coins, they also carried specialiy struck copper medals. While these medals are mentioned in John Hoskin's narrative of the voyage (Howay, Voyages of the "Columbia", p. 162), he says nothing about the Massachusetts Cents. Unfortunately, Greenhow does not say what authority his remark was based on.

25 It will be recalled that this is the same place the Spanish saw edged iron implements, including "half a bayonet and a piece of a sword," as early as 1774 (see Pérez, "Diario," July 20-21, 1774).

$$
\begin{aligned}
& 26 \text { Marchand, Voyage, I, } 419 . \\
& 27 \text { Ibid., I, 420-421. }
\end{aligned}
$$


AMERICAN VOYAGES

Ships flying the United States flag were the last to arrive on the Northwest Coast, but in time they would come to outnumber those of all other nationalities. ${ }^{1}$ while American ships are known to have appeared initially on the coast in 1788, there are some questions as to which was actually first. The ship Columbia Rediviva, under John Kendrick, and her consort the sloop Lady Washington, Robert Gray master, rendezvoused at Nootka Sound in 1788 after sailing out of Boston by way of Cape Horn. The sloop arrived September 17, a week ahead of the Columbia, and she is often regarded as the first ship flying the Stars and Stripes on the Northwest Coast. ${ }^{2}$ Yet there is some evidence, albeit slender, that another American ship, the Eleanora commanded by Simon Metcalfe, sailing out of Macao, reached the same coast sometime before September, 1788.3 While the order in which these ships first arrived may seem only of incidental importance, the possibility that the Eleanora could have been on the coast early in 1788 creates some uncertainties for this inquiry. If she was in fact trading on the coast then, and with nothing known of her itinerary, she conceivably could have been 
responsible for the distribution of European or Asian goods at any number of places on the coast, such as the Chinese money Colnett saw at Yakutat Bay in June, 1788, or even the clothing and Massachusetts Cents Marchand mentioned at Sitka Sound in 1791. These may only be slight possibilities, but they cannot be entirely ignored. 4 whether her voyage of 1788 was apocryphal or not, the Eleanora's appearances in $1789,1790,1791$, and 1794 seem well attested by eyewitness sightings of the ship or trade goods clearly attributable to her. 5 Metcalfe must have been very active in the fur trade, and accounts of his voyages would no doubt be valuable for the purposes of this inquiry. Unfortunately, none seems to have survived.

The voyages of the Columbia and Washington on the other hand are relatively well documented, and most of their tracks and activities can be traced in some detail. 6 For the most part, Kendrick and Gray tended to confine their trading to areas south of Dixon Entrance. Both ships arrived too late in the 1788 season to mount a trading expedition northward, and they prudently decided to winter at Nootka Sound. There they soon discovered the native population was not only selective in what they accepted in trade, but drove hard bargains as well. Robert Haswell, the Columbia's third mate, wrote in November, 1788:

Copper was the article in demand this we were unprovided with and the only substitute was Iron worked into chizeles after their own plan these they soon redused the value of inhancing the prise from three 
chizeles to ten but had they been kept at three far more skins would have been purchased.?

In the following spring of 1789, the Washington, under Gray's command, was sent out to purchase furs wherever they could be obtained at lower prices than those prevailing at Nootka. They quickly found the natives at nearby Clayoquot Sound (about $30 \mathrm{~km}$. south of Nootka) were supplied with "plenty of skins which they told us they would rediely part with for Chizeles or Copper but of the former they demand an exorbutant price ten for a skin and the latter we are totaly destitute of ${ }^{8}$ Continuing southward in search of cheaper pelts, the Washington stood in towards the coast on April 19 at a point somewhere immediately south of Cape Alava in Washington state where they obtained "several good sea otter skins at 5 Chizels each."9 Apparently the winds and currents, however, were unfavorable for going farther south and

on Monday [April 20, Haswell writes] we found we were only 4 miles to the southward of Chandee or Tatooche's [Tatoosh] Island while in this situation the Chief with 2 canoes came off and sold upwards of 20 prime Skins and they departed well pleased with recieving 5 Chizels each and promised to bring a great number more the next day. so strong did the current set that tho' it was Calm allmost all the succeeding night we were huried into the Straits [of Juan de Fuca] at daylight several Canoes came off and upwards of 30 sea otter skins were purchased but we had the Mortification to see them carey off near 70 Others all of excellent quality for want of Chizels to purchace them. 10

Their trade at Tatoosh and near Cape Alava thus suggested clearly that furs decreased in value as one moved away 
from Nootka and Clayoquot sounds southward across the Strait of Juan de Fuca. This was further confirmed by their experiences the previous summer trading on the Oregon coast (probably at Tillamook Bay) where the natives "would hand there skins onboard without scruple and take with satisfaction whatever was given in return." 11

The Washington returned to Nootka Sound on April 22, where the ship underwent minor repairs, and she was resupplied with wood and water. "The [Columbia's] smiths," Haswell noted, "were immediately employed to furnish us with another cargo of Chizels."12 By May 2, she was bound away to the North to see if the price of furs in that direction was better. After passing Cape Scott, the northernmost point of Vancouver Island, they headed north across Queen Charlotte Sound to the British Columbia mainland in the vicinity of Milbank or Laredo sounds where a lone canoe was encountered. Haswell observed that

they were in a Canoe exactly like those used by the natives in Juan de Fucas Strait and I am of opinion thare must be some inland communication by lakes or perhaps the sea may continue by large arms and have communication in the interior parts perhaps by the way of Pintard [Queen Charlotte] Sound.1

The language of these people "differed intierly from the natives" at Nootka (they were probably Kwakiutl) and "Iron was the only article of trade held in high estimation by them we purchaced of them between twenty and thurty sea Dtter skins for a very trifling number of Chizels." ${ }^{14}$ The Washington next proceeded northwesterly across Hecate 
Strait, sailing briefly along the eastern side of the Queen Charlotte Islands, after which she returned to the mainland in the vicinity of Brown Passage near Prince Rupert, British Columbia. There they encountered natives (probably Tsimshians) willing to trade "their skins... for 2 or three picks each and a Chizel or two."15 They were now directly east of Dixon Entrance some $640 \mathrm{~km}$. northwest of Nootka and their experience again confirmed that prices were lower as they moved away from their base on Vancouver Island.

From Brown Passage, the Washington headed west through Dixon Entrance towards the open ocean, where she turned northward along the west coast of Dall Island. She Ieached the vicinity of Bucareli Bay, and shortly thereafter Haswell recorded her northernmost latitude on May 28 at $55^{\circ} 43^{\prime} \mathrm{N} .^{16} \mathrm{He}$ says nothing of trade with natives while they were in Alaskan waters, but on their return they stopped at Langara Island (northernmost of the Queen Charlottes and separated from Graham Island by Parry Passage) on the south side of Dixon Entrance where they purchased "two hundred skins in a very fue moments for one chizel each."17 The Washington next moved south along the outer coast of the Queen Charlottes, where they saw no native habitations until reaching Houston Stewart Channel at the southern extreme of this archipelago on June 11. The location was named Barrell's Sound, ${ }^{18}$ and there they encountered natives 
eager for trade. Of these people Haswell wrote:

A brisk trade was soon set on foot by Coya the Chief who bartered for all his subjects, and a number of Sea Otter skins were purchased before night. Iron was of far less value with them than with those natives we were last with cloathing was most in demand these people had been visated by several navigaters they spoke distinctly of Colinnet and Dunkin and they brought a pece of Paper that Informed us the NW American Schooner had been here May the 24 th last. 19

The Washington returned to Nootka Sound on June 16, 1789, where the Columbia, under Kendrick, had remained. The two vessels than went together to Clayoquot Sound, where the furs collected by the sloop were transferred to the Columbia, and the two captains, Gray and Kendrick, exchanged ships. The Columbia, now under Gray, set sail for China to dispose of the furs, eventually returning to Boston by way of the Cape of Good Hope--and thereby becoming the first American ship to circumnavigate the globe. Kendrick, in the Washington, remained on the coast into autumn, trading at locations to the northward of Nootka, apparently in the Queen Charlotte Islands, before also sailing for China where he arrived in mid-January, 1790. Details of Kendrick's northern sojourn, however, are sketchy and based only on secondary evidence. 20

Gray returned from Boston, arriving on the coast in June, 1791, in command of the Columbia. He anchored first in Clayoquot Sound on Vancouver Island, where, as recorded by the ship's clerk, John Hoskins,

Our principal articles of traffick were copper and 
cloathing; iron they would scarcely take as a gift: for a sheet of copper we got four skins; cloathing in proportion. for small articles, such as knives, buttons, fish hooks, gimlets etca. we proçpred a few sea otter tails, fish and vegetables.

Farther north on the Vancouver Island coast, at an anchorage near Cape Cook, which Gray named Bulfinch Sound, 22 copper and clothing continued in high esteem, although "iron was more valuable than at Clioquot; trifling articles were also in demand." 23

The Columbia then steered southeasterly along the Vancouver Island coast to see what success might be obtained at Tatoosh Island off Cape Flattery, where Hoskins recorded the following incident:

On the moring of the 29th [of June] Tootooch's island bore east south east, seven leagues distance; many canoes from the village bound a fishing; one of which was dispatched to inform the Chief of our arrival. at four in the afternoon, several canoes came of $[f]$ with skins; a brisk trade ensued, which lasted until late. The next morning, saw a vast number of canoes, bound out a fishing; in one of which was Tootooch the Chief; who came on board and requested us to tarry until the evening; as he said fish was very plenty now, and he, as an example to others, must go to catch them himself, therefore till then he could not spare time; when he would fetch of many skins; but in this he deçived us, for few were purchased, and none of him. 24

At noon that same day, Hoskins goes on to note, a native named Tootiscoosettle, a chief from Clayoquot Sound, visited the Columbia briefly on his way to Tatoosh Island. "I believe this man," wrote Hoskins, "was of no service to us; for had he not came here; I have reason to think Tootoosh would have kept his word." 25 This suspicion, if true, 
would imply that an effort was being made to control trade to the advantage of the inhabitants at Clayoquot Sound, some $150 \mathrm{~km}$. to the northwest. Whatever the truth, these events convinced Gray that they should head northward to the Queen Charlotte Islands.

On July 8 , they reached the same anchorage Gray had previously (in 1789) called Barrell's Sound at the south end of the Queen Charlottes. Here they discovered that the chief named Coya had, in the meanwhile, suffered some sort of humiliation and demotion, and that his people had been greatly reduced in number. ${ }^{26}$ The "principal articles of traffic were chissels, or rather peices of Iron, rufly formed into a similar shape," 27 says Hoskins; and this time, in contrast to Gray's previous visit when Coya handled all transactions, the women now controlled the trade, "as no one dared to conclude a bargain without first asking his wife's consent." 28 The interest these people had earlier (in 1789) exhibited in obtaining clothing was now reflected in the way they were attired:

Their dress [Hoskins wrote] is a sort of mantle, made of various skins . - also european cloth and clothing, on which they have sewed in various directions as fancy or fashion suggests buttons, thimbles, china cash, peices of shell, etca. in this dress they have truly a grotesque appearance.29

They now crossed Hecate Strait to the vicinity of Banks Island off the British Columbia mainland, but finding little there to encourage them, the Columbia recrossed the strait to Cumshewa Inlet 30 on the central east coast of 
the Queen Charlotte Islands. They traded there briefly with natives from a village called Tooschcondolth, but Hoskins recorded few details of this exchange. 31 By August 1, they left Cumshewa and stretched to the north where they entered the Alaskan waters of Clarence Strait. While in the vicinity of Cholmandeley Sound, an arm of water on the strait's western shore, 32 they engaged in considerable trade, about which neither Hoskins nor fifth mate John Boit unfortunately state what was used to purchase the furs.

During their sojourn in Clarence Strait, however, two incidents occurred which would provoke graphic and useful descriptions. On August 11, an elderly chief named Clinokah, who apparently was from a village called sushin on Cholmondeley Sound, was aboard the Columbia, when Hoskins recorded the following events:

In the afternoon there was a large canoe full of natives entered the Sound Chinokah on seeing it appeared to be quite frantic running about the decks like a madman calling to his canoes that were ashore to come of $[\mathrm{f}]$ and requesting us to fire at the strange canoe and support him for he said they were coming to kill him as soon as his canoes came of [f] the natives came on board drew their daggers ran fore and aft brandishing them bawling most vociferously and offering by the most threatening motions and gestures every possible insult to these strangers. 33

It is uncertain where these strangers were from, but whoever they were they clearly had different tribal affiliations than clinokah and his people. The encounter thus seemed to have grave potential for conflict. Nevertheless, as Hoskins goes on to explain, the incident had quite a 
different outcome than might have been expected:

the canoe then advanced towards us singing the one who I supposed was chief standing up in the middle apparently unarm'd when within about fifteen or twenty yards of the ship they stopt and a conference was opened between the two chiefs which continued for sometime with the greatest vehemence when it appeared to be settled... Clinokah and his people had a private conference after which the strangers gave an entertainment first of dried fish then of berries.. - when this feast was over both parties joined in an agreeable song sung to the most lively air. Matters to appearances being thus happily adjusted Clinokah introduced to our acquaintance this new Chief with whom we could not speak a word as he talked a language very different to what any of us have yet heard he brought several fine skins which were soon purchased as Clinokah was good enough to be our interpreter and to trade for him. 34

The language difference Hoskins noticed suggests strongly that these strangers must have been Tlingits from somewhere on the eastern shore of Clarence Strait, since the native languages Gray's men had previously heard could only have been Nootkan, Kwakiutl, Tsimshian, or Haida. 35 This episode thus seems to confirm the possibility of trade connections between the Tlingits and their neighbors to the south, despite cultural differences.

On the following day a second incident occurred that had a far less happy conclusion. Three men from the Columbia, second mate Joshua Caswell, boatswains mate John Folger, and seaman Joseph Barnes, while fishing in the ship's jolly boat in a cave near Chomondeley Sound, were attacked and killed by the natives. 36 The fishing party carried a single musket, which was heard to discharge. 
When the boat failed to return, the ship's pinnace was dispatched to find it, only to discover the boat anchored near shore with Caswell "laying dead in the bottom of the boat stripped perfectly naked and stabbed in upwards of twenty places." 37 Barnes' body was seen on the beach clad only in trousers, and Folger was missing entirely. Both Hoskins and Boit speculated that the natives had been prompted (as Hoskins put it) "by a desire to possess themselves of their cloaths and arms. ${ }^{38}$ whatever their exact motives, it seems that European-style clothing exercised an inordinate fascination on the natives, and that this unhappy incident may have been among the first in which Tlingits south of Yakutat Bay obtained firearms-of which, it will be recalled, Vancouver reported an abundance within two years just a short distance farther up Clarence Strait at Behm Canal. 39

The Columbia now returned to the Queen Charlotte Islands, stopping to trade briefly at Masset Sound on the northeast shore of Graham Island, and moving on to Cumshewa Inlet by August 22. Here Hoskins remarked:

Several canoes came of [f] in one of which was Comsuah who informed us there was but few skins at his village [Tooschcondolth] at present yet if we would wait ten days they would procure a plenty pointing towards the continent and giving.us to understand 'twas from that quarter he would get them. 40

It is apparent from Hoskins' remark that trade connections must have existed between the Haida at Cumshewa Inlet and 
the Tsimshians inhabiting the British Columbia mainland across Hecate Strait, which at that point is $100 \mathrm{~km}$. wide. Earlier in August when the Columbia had crossed over from the mainland, Hoskins' narrative noted that they "saw two canoes at a great distance coming in from sea," and that its occupants "informed [us] they saw us on the main and had followed us over." 41 Crossing such a wide expanse of open ocean was no small navigational feat, upon which Hoskins later reflected:

That these people trade with those over on the main for skins etca. is certain but as one shore cannot be seen from the other at Tooschcondolth over it surprizes me what guide those natives could have had who visited us there when it was foggy at the time and had been for several hours before so that they could no have an opportunity of being directed by the stars which makes it the more wonderful in all probability there is yearly many overtaken by storms and lost indeed the natives have informed me that is sometimes the case on asking Cumsuah what guide they had to direct them he would answer by pointing up to the heavens on telling him it was thick and they could not see he would still answer by pointing up to heaven intimating thereby that there was one above who would always guide, protect and direct them that was good. 42

Gray decided he could not wait ten days for the promised furs from the mainland, so on August 23 the Columbia set sail bound for Clayoquot Sound to spend the winter.

Shortly before they left, however, the Columbia was visited by a boat from another American ship, the brigantine Hope commanded by Joseph Ingraham, which was anchored well within Cumshewa Inlet. 43 Ingraham, who had been the second mate of the Columbia during her previous voyage to 
the coast, was now in command of his own ship which had sailed out of Boston in September, 1790. 44 Unlike Gray, who tended to move frequently from place to place, Ingraham's fur-trading strategy was to stay in one location at some length once it was determined to be profitable. It was in fact the Hope's presence at Cumshewa during the previous two weeks that had stripped the locality of most of its furs.

Although Ingraham's movements, by being more restricted than Gray's, offer fewer clues about the native trade network, his activities were destined to play a significant--if curious--role in the maritime fur trade. Soon after the Hope's arrival on the coast in July, 1791, she put in at Parry Passage 45 between Langara and Graham islands at the northern extreme of the Queen Charlotte group. There Ingraham was dismayed at seeing that "many of the natives had on blue jackets and trowsers which from their appearance it was evident they had possessed but a short time; these they informed me they got from Captain Douglas." 46 Ingraham was even told by some of the natives that he "had best go away for Douglas had bought all the skins - . 47 But on the urgings of a chief named cow, the Hope stayed on with promises that furs would presently be made available. Ingraham's patience proved justified and with some added ingenuity he turned this seemingly discouraging situation into one of opportunity. He wrote 
in his journal:

In the morning [of July 12] I had the forge set up and set the smith to work to make iron collars of three iron rods twisted together about the size of a man's finger. These I had made from a pattern I saw on a woman's neck alongside. When finished they weighed from five to seven pounds and would purchase three of their best skins in preference to anything we had on board. Likewise heavy iron rings or bracelets for the wrist were preferred before our polished copper oness so much esteemed by the ladies of Nootka Sound. 48

Such collars continued to be traded that summer (of 1791) by Ingraham on the southeastern coast of the Queen Charlottes, particularly at Cumshewa, where the natives were so eager to obtain them that "making collars became so far the work of necessity that, notwithstanding our respect for [Sunday], we kept the forge at work." 49 They were for a time in great demand, being traded by the natives themselves considerably beyond the points visited by Ingraham. 50 But when the Hope returned to Parry Passage in July, 1792, her captain would discover that tastes could change quickly and unaccountably:

I produced our articles of trade, but the things which they esteemed highly when $I$ was here before were now of little value. To my great surprise tablespoons were eagerly enquired for--articles they would scarcely accept as a gift when I was here before. For collars one skin was offered, and clothes were scarcely noticed.

- - Copper, which they never wanted when we were here last year, was now asked for. I had plenty, but it was all too thin. Leather for war garments was another article they wanted and a variegated shell, green and white, a species of pearl. 51

Besides the considerable success of Ingraham's fur- 
trading strategy during the 1791 season $^{52}$ and the role his celebrated collarsplayed in this, one additional distinction may have also attended his activities. While the Hope was at Cumshewa Inlet, Ingraham mentions that in his dealings with a chief he calls skutkiss he obtained "two tolerable skins for which I gave him a pistol." 53 This was on August 10, two days before the attack on Gray's three men on Clarence strait in which a musket was apparently acquired forceably by the natives. The pistol, however, was by Ingraham's own admission traded to Skutkiss, and this may have been one of the earliest instances where firearms were used as trade goods. It will be recalled that when Marchand was at Parry Passage in August, 1791, he noted that at least four muskets were possessed by one chief. 54 Moreover, his second officer, Prosper Chanal, reported that another native specifically requested payment for sea otter pelts in muskets and powder--which Chanal "positively refused to grant." 55 Marchand disapproved of the trade in firearms, fearing "that the mercantile avidity of the English, if they continue to supply the [native] Americans with muskets and powder, may have sacrificed to the interests of the moment their future safety, and that of navigators who may frequent these islands." 56 Whatever truth there may have been in this allegation, it is clear from Ingraham's own admission (to say nothing of incidents such as the attack on Gray's 
three men) that it was not English "mercantile avidity" alone that introduced the natives to firearms.

Ingraham left the coast, bound for China, shortly after the Hope's brief encounter with the Columbia at Cumshewa on August 22, 1791. Gray, however, after reaching Clayoquot Sound on Vancouver Island, remained there over the winter, during which time his men constructed a sloop they would name Adventure. 57 Robert Haswell took command of the sloop, and headed her northward to the Queen Charlottes in the spring of 1792, while Gray went south in the Columbia.

Haswell returned to Parry Passage in April, hoping for more of the lucrative trade that had prevailed there before, but instead he found the natives "were so exorbitant in their price as to ask two great coats for one skin." 58 Just as Ingraham discovered on his second voyage in 1792, native preferences were now changing so rapidly from season to season--even place to place--that it was becoming difficult for the fur traders to anticipate what kinds and quantities of articles would best serve their purposes. Haswell moved on to Cumshewa, with somewhat better results, although no particulars of the exchange rate are mentioned in his account. The Adventure then retraced the Columbia's 1791 track in Clarence Strait, about which details are similarly sketchy, and where it appears that the level of trade was insufficient to induce 
them to remain. They returned briefly to the east end of Parry Passage, where the natives had an abundance of furs, but "they asked such a price for them," says Haswell, "that it would have taken all the salable articles I had to purchase 70 of them." ${ }^{59}$ Continuing out through Dixon Entrance, the Adventure sailed up the outer coast past Bucareli Bay to Sitka Sound, where on July 21 some natives were encountered who protested that they had already sold their furs to others. "They told me," wrote Haswell, "they had been visited by some other vessel with 2 masts, who had sold them a quantity of clothing." 60 Haswell thus reached the northernmost point of his voyage, and with no better prospects apparently there, he turned south again rejoining the Columbia early in September off the outer coast of the Queen Charlottes somewhere just north of Houston Stewart Channel. 61 The Adventure's northern voyage had not been especially successful, for all Haswell had to show for his efforts since late June were "75 sea otter skins, 29 cootsacks, 137 tails, and 25 pieces." 62 When they returned to Nootka in late Spetember, the sloop itself was sold to the Spanish for nearly as much. 63

The Columbia on the other hand, had fared much better trading southward of the Strait of Juan de Fuca along the Washington and Oregon coasts. For one thing, she had had the good fortune to find and enter Grays Harbor and the Columbia River estuary, localities with large native pop- 
ulations which had hitherto been unexploited by the fur traders. 64 John Boit, the Columbia's fifth mate, wrote of their experience at Grays Harbor:

Without doubt we are the first civilized people that ever visited this port, and these poor fellows view'd us and the ship with the greatest astonishment... we purchas'd many furs and fish.

[May] 8 - . Vast many Canoes along side, full of Indians. they brought a great many furs which we purchas'd cheap for Blanketts and Iron. 65

A few days later, when they entered the Columbia River's mouth, Boit would describe a similar scene:

the River extended to the $N E$ as far as eye cou'd reach, and water fit to drink as far down as the Bars, at the entrance. we directed our course up this noble river in search of a Village. The beach was lin'd with Natives, who ran along shore following the ship. Soon after above 20 canoes came off, and brought a good lot of Furs and Salmon, which last they sold two for a board $\mathrm{Nail}$. the furs we likewise bought cheap, for Copper and Cloth. they appear'd to view the ship with the greatest astonishment and no doubt we was the first civilized people that they ever saw . . at length we arriv'd opposite to a large village, situate on the North side of the river about 5 leagues from the entrance... We purchas'd 4 Otter Skins for a Sheet of Copper, Beaver Skins, 2 Spikes each, and other land furs, 1 Spike each.66

During the week they spent within the river's estuary, boit says they "collected 150 Otter, 300 Beaver, and twice the Number of other land furs." 67 when the Columbia finally departed the coast early in October, 1792, the preponderance of her cargo of furs appears to have come from Gray's activities outside of the Queen Charlotte Islands, ${ }^{68}$ and the contribution of the Cape Flattery-to-Columbia River 
section of the coast alone must have been substantial.

The voyage of another American ship that arrived on the coast the year after Gray's departure shed some additional light on the role of the Columbia River in the fur trade and its relationship to the North. The ship Jefferson, commanded by Josiah Roberts, sailed out of Boston in November 1791; she rounded Cape Horn in March, 1792, and reached the Marquesas Islands in November, 1792.69 While in the Marquesas, Roberts constructed a small schooner, naming it Resolution for the bay in which she was launched. The Jefferson and her consort sailed for the Northwest Coast by way of the Hawaiian Islands and after an uneventful cruise north along the Oregon and Washington coasts, they reached Barkley Sound on Vancouver Island, May 28, 1793. Discovering the high price of sea otter furs at nearby Clayoquot Sound (they were still 10 chizels or "toes" per pelt), Roberts headed for the Queen Charlottes while his "smith was kept at work making iron collars and large tin kettles."70 On July 4, the Jefferson anchored at Houston Stewart Channel (near Coya's village), where Roberts discovered the natives had sea otter pelts in abundance--but which could be purchased by one commodity only. Leather war garments of dressed "moose" (i.e., elk) skin, which they called clemons (also spelled clamons), were all that the natives would accept, and of these Roberts had none. He moved north along the seaward west 
coast of the Queen Charlottes, while the Resolution sailed separately up the eastern shore. The Jefferson reached Parry Passage at the island group's northern end on July 12, where the prevailing exchange rate was a "coat and trousers or an overcoat, for a skin." 71 Being able to purchase only 60 pelts at that price, Roberts continued north rejoining the Resolution at Bucareli Bay. There he managed to buy only " 24 skins, each of which cost a musket and two pounds of powder or $1 \frac{1}{2}$ yards of cloth $1 \frac{1}{2}$ yards wide and two or three iron collars." 72

In the face of these frustrations, Roberts decided to send the Resolution south to the Columbia River to purchase a supply of tanned elk leather for resale in the North, which ironically would make these Boston fur traders middlemen in the natives' own trading network. In September, the Jefferson returned to Barkley Sound, where the Resolution awaited her. The schooner had in fact been to the Columbia River, where she "obtained 63 sea-otter skins, superior to any that had been collected, and 27 moose skins," 73 all purchased with copper and cloth. During the winter of 1793-1794, the Jefferson and Resolution remained at Barkley Sound ${ }^{74}$ where Roberts seems to have tried every device he could think of to supply himself with articles resaleable in the North for sea otter pelts. He kept his smith busy "making iron swords for the Columbia River trade" 75 ; he tried tanning seal skins that 
had been obtained earlier at St. Ambrose Island of $f$ the Chilean coast as a substitute for clemons; "moose" skins were purchased locally at a musket each; and "two brass field pieces were given for two moose skins." The carpet in the captain's cabin purchased five clemons from Tetacus, a chief who had come up from the Strait of Juan de Fuca. 76 Roberts even dealt in haiqua (Dentalium pretiosum Nuttal),77 the natives' own standard medium of exchange and value:

the natives on the Columbia River would gladly exchange a prime sea-otter skin for a fathom [ $6 \mathrm{ft}$. of those slender shells which could be purchased [on Vancouver Island] for a pound of powder In the course of the winter 160 fathoms [960 $\mathrm{ft} . \mathrm{j}^{\circ}$ of haiqua were purchased from the different tribes at varying rates: a short jacket for a fathom, or a musket for six fathoms, or an iron sword for two fathoms. 78

By spring, Roberts had assembled a trading stock amounting to 210 clemons, the haiqua, "60 sheets of copper, 400 iron swords, some iron collars, a few muskets and pistols, and a little powder." 79 This was not considered sufficient, so on April 3, 1794, the Resolution sailed again for the Columbia River with plans to purchase additional elk skins, following which she would sail for the Queen Charlottes to augment the Jefferson's trading stock. Judging by later reports of iron swords among the Columbia River natives, ${ }^{80}$ she must have successfully purchased clemons with some of the 400 swords made at Barkley Sound. The Jefferson, in the meanwhile, proceeded to the east coast of the Queen Charlotte Islands where she began trad- 
ing near Skincuttle Inlet, purchasing sea otter pelts at the rate of three per elk hide. Roberts moved north to Atli Inlet where, hoping the Resolution was not far behind, he left a letter for her captain ${ }^{81}$ with one of the chiefs. At Cumshewa, $35 \mathrm{~km}$. farther up the coast, they "procured 7 cutsarks, 94 sea-otter skins, and 57 tails," 82 and by the end of May the Jefferson was trading at Parry Passage. Roberts' supply of elk skins was now nearly exhausted, and he was anxiously looking for his consort. At that moment, however, the Resolution must have been far to the south of the Queen Charlottes, and Roberts was in fact destined never to see his escorting schooner again. Apparently, sometime in July, while anchored at Cumshewa, the Resolution was attacked, overcome, and destroyed by the natives. Only one member of her crew survived. 83

As time passed and the Jefferson's escort failed to appear, Roberts grew desperate. An abundance of furs--as many as 800--had been brought to Parry Passage when all of its summer inhabitants returned from their winter villages across Dixon Entrance on Dall Island. In the midst of this wealth and without the additional elk hides he had counted on, Roberts turned to what Howay describes as "the Yankee genius for swapping." 84 Practically anything aboard ship that was not essential was used to purchase furs: worn out studding sails; a Japanese flag; seal oil (from St. Ambrose Island); old clothing of the crew; the cabin looking- 
glass; the officers' sea trunks; a small seine; an anchor; a powder horn; a pitch pot; 60 pounds of two-inch rope; 29 wooden boxes made by the ship's carpenter; even the captain's old clothing. The ship's longboat brought 35 sea otter pelts. Their "bar iron was unsaleable," although by "transforming it into bangles for the adornment of women" they were able to purchase a single pelt for twenty such bangles. ${ }^{85}$ Roberts even obtained some furs by attendance at a potlatch, the description of which is of great interest for, besides being one of the earliest accounts of this ceremony, it helps to explain the extensive trade in elk hides linking the Haidas with people as far away as those at the Columbia River. Howay quotes directly from the account of Bernard Magee (Roberts' first officer):

The house was thronged with guests and spectators. The scene was then opened by the ceremony of introducing the wives of Enow and Canneah [Cania] (two of the chiefs) and the candidates for incision or boring, each coming in separately and backwards from behind the scenes--being saluted by a regular vocal music of all present and which had no unpleasant effect. In the same manner the presents were ushered in and displayed to the view of all present and thrown together in a heap being a profuse collection of Clamons (war garments), racoons and cutsarks, comstagas both iron and copper and a variety of ornaments. This being done the spectators were dismissed and the guests placed in order round the house. The incision was then performed on the lips and noses of two grown and two small girls which ended the distribution was then begun of the above articles, the Captain receiving 5 otter skins and other articles were distributed among the different chiefs according to their distinction, after which the capt. took his leave and returned onboard. 86

The Jefferson finally left the coast bound for China 
via Hawaii on August 17, 1794, with about 1,475 sea otter skins. This was a respectable quantity, 87 but the records of her trading activities and those of her consort, the Resolution, bear witness to how resourceful Roberts and his men needed to be in overcoming many unsuspected obstacles to trade. Besides revealing the great variety of trade goods (native as well as non-indigenous) that the fur traders were forced to resort to in the mid-1790s in their sometimes frantic efforts to scour the coast of sea otter furs, this voyage also suggests that native trade links must have existed between the Queen Charlotte Islands and the Columbia River vicinity--if not directly, then through middlemen, some of whom were the men of the Jefferson and Resolution. 
1 Warren Cook, Flood Tide of Empire, p. 551, lists 450 ships on the coast between $177 \overline{4}$ and 1820 , based primarily on Howay, "A List of Vessels in the Maritime Fur Trade." of these, 275 were American. Cook's list does not include Russian vessels north of Sitka, of which Makarova, Russians on the Pacific, pp. 209-216, lists 93 between 1743 and 1799. While a full accounting of all Russian ships from 1741 to 1820 comparable to Cook's list is unavailable, it seems unlikely that it would exceed the 275 American ships known to have visited the coast up to 1820.

2 Howay, Voyages of the "Columbia", p. vii.
${ }^{3}$ The principal evidence suggesting this possibility is contained in John Boit's Loq of the Union (Edmund Hayes, ed., PP. 70-73). John Boit, Jr., who had been fifth mate on the Columbia's second voyage, commanded the sloop Union on her voyage to the Northwest Coast in 1794-1796. While in Hawaii on the way to China, Boit met a young Englishman named John Young who claimed to have "been Boatswain on the Snow Elenora belonging to Newyork Capt. Metcalf" (Hayes, p. 70). In describing a small schooner then in possession of King Kamehameha I, Young remarked that it had been "formily own'd by Capt. Metcalf, [and] it appear'd that Capt. M. had purchas'd this small Vessel at Macao, after his arrival at the port in the Elenora from the NW coast" (Hayes, p. 73). The vessel referred to must have been the Fair American which is known to have been on the Northwest Coast in 1789 and later captured by natives in the Hawaiian Islands (Howay, "A List of Trading Vessels," Iransactions, 3rd series, 24 , sec. 2 (1930), P. 118). Young thus implied that Metcalfe had been on the Northwest Coast the previous year (1788) with the Eleanora. Howay, Voyages of the "Columbia". P. $x$, also notes that "the records of the East India Company show that the American brig Eleanora, Captain Simon Metcalfe, arrived in Canton on August 12, 1788 from Bengal and Batavia. 'She left America last season,' says the entry--whatever that may mean."

\section{${ }^{4}$ Since Metcalfe is supposed to have sailed from} Macao it is entirely possible that Chinese coins could have been among his trade goods. As to the English clothing and American coins at Sitka Sound, the Eleanora was apparently originally out of New York and it thus seems unlikely--though by no means impossible--that she was supplied with coins from a Massachusetts mint, nor is it any more likely that English clothing would have been among her goods. 
5 On July 26, 1791, Joseph Ingraham's Journal of the brigantine Hope (Ingraham, Voyage to the Northwest Coast of North America, $p .115)$ records that at Skincuttle Inlet, Queen Charlotte Islands, "the natives informed me Captain Metcalfe had been at anchor there some time and showed buckles which he had left among them which had engraved on them 'Eleanora, Metcalfe." Other references to sightings of the Eleanora are in Howay, "A List of Trading Vessels," Transactions, 3rd series, 24 , sec. 2 (1930), Pp. 118, 120, 132.

${ }^{6}$ Accounts of these voyages are in Howay, Voyanes of the "Columbia". The principal narratives are: the socalled logs (really journals) of Robert Haswell, Gray's third mate on the first voyage and first mate on the second; the narrative of John Hoskins, clerk or supercargo on the Columbia's second voyage; and the log kept by the Columbia's fifth mate, John Boit, on her second voyage.

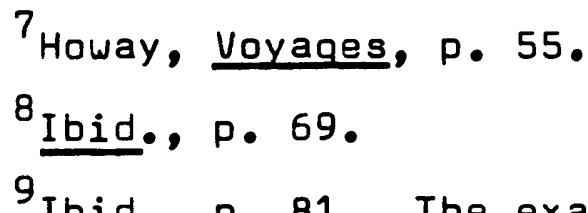

is a matter of some interest since an Indian petroglyph depicting a sailing ship is located about a mile south of Cape Alava at Wedding Rock (see Danial Leen, "The Rock Art of Western Washington," Northwest Anthropological Research Notes, 15, No. 1 (1981), p. 42, fig. 27c). Hasweli notes that they "lay too of this place where there is a village little to the southward of foggy Rocks [Flattery Rocks of Cape Alava] off which place we were on the $26 \mathrm{th}$ of August 1788" (Howay, Voyages, p. 81). In his entry for August 26, 1788, Haswell remarks "I observed in Latd. $48^{\circ} 5^{\prime}$ No. and Longitude 124050' $W$ and to the ENE lay a very Deep Bay in the enterence of which lay a great many Islands to this was given the nam [e] of Companys Bay and there is but little doubt but it affords Cood Harbours" (ibid., p. 42). It appears that Haswell's "Companys Bay" was Barkley Sound on the coast of Vancouver Island, but from his stated latitude it seems fairly certain that on August 26, 1788, they were sailing along the coast immediately south of Cape Alava. As to whether the petroglyph at Wedding Rock has any connection with either of the Washington's visits to this locality remains uncertain because the ship depicted in the rock drawing has two masts while the Washington was a single-masted sloop.

10 Ibid., $p .81$.

${ }^{11}$ Ibid., pp. 35-36. The natives at Tillamook Bay did 
exhibit a preference for copper, but they were apparently quite willing to accept iron tools such as axes and adzes without a clearly defined exchange rate as was seldom the case elsewhere. Haswell (ibid., p. 36) says that "this we very seldom found the case in any other part of the coast."

\section{Ibid., P. 82.}

13 Ibid., P. 87. Haswell was of course correct in this conclusion and he must have suspected that Nootka Sound was situated on the seaward side of a very large island. Some remark to this effect, greatly distorted, may have been the basis for the feature that appears on Meares' "Chart of the N.W. Coast of America.." which depicts an inland connection between the Strait of Juan de Fuca and a point north of the Queen Charlotte Islands bearing the notation "Sketch of the Track of the American Sloop WASHINGTON in the autumn of 1789." In addition, Haswell's remark also implies that trade connections must have existed along the inland side of Vancouver Island bypassing the Nootka Sound vicinity.

$$
\begin{aligned}
& 14 \text { Ibid., P. } 87 . \\
& { }^{15} \text { Ibid., } P .90 . \\
& { }^{16} \text { Ibid., } P .95 . \text { This is the latitude of Iphigenia }
\end{aligned}
$$
Bay, roughly half way from Dixon Entrance to Sitka Sound.

${ }^{17}$ This celebrated bargain was apparently struck with the Haida inhabiting the village called Kuista (variously spelled Custa and Kioosta) at Parry Passage. These were the same people Juan Pérez had encountered in 1774, and from whom Dixon purchased 300 furs in 1787, calling the location Cloak Bay (see ibid., P. 96; Pérez, "Diario," July 20-21, 1774; and Dixon, Voyage, Pp. 199-203). As noted earlier ( see pp. 122-123, ns. $20,22,24$ ), it may have been during this encounter that the Massachusetts Cents seen by Marchand at Sitka Sound were obtained by the natives. Haswell's account, however, is silent on the matter.

18 Howay, Voyages, pp. 97-98. This suggests that Colnett and Dunkin, during their trading activities in 1787-1788, may have initiated the popularity of clothing as a trade item. The schooner mentioned is the Northwest America, built by Meares at Nootka Sound where she was launched in September, 1788. She was commanded by Robert Funter on "a trading expedition amongst the Charlotte's Isles" sometime just prior to June 9, 1789, when, according 
to a deposition later signed by her officers and men, she returned to Nootka Sound. The deposition also indicates that they obtained "two hundred and fifteen sea otter skins of good and prime quality," but nothing is said about what was used to purchase them (see Meares, Voyages, Appendix No. $X$, "Deposition of the Officers and Men of the Schooner North-West America").

${ }^{19}$ The name honored Joseph Barrell, the principal owner in the venture (see Howay, Voyages, P. 97, n. 4).

20 Hoskins (ibid., p. 164) says that Kendrick went "in the washington on a cruize to the northward to finish the season," and "after cruizing round Washington's Island [Queen Charlotte Islands] where many skins were procured: proceeded . . to China." Robert Greenhow, History of Oregon and California, pp. 217-219, believed that Kendrick sailed up the Strait of Juan de Fuca and thence northward along the back side of Vancouver Island, before reaching the Queen Charlotte Islands. This, he argued, was the basis of the track shown on Meares' map depicting such a voyage (see $n_{0} 13$ above). Henry Dak (Bancroft's assistant) was skeptical of this claim, however, pointing out "that Kendrick is not known to have made subsequently any claims to a discovery so important" (see H. H. Bancroft, History of the Northwest Coast, I, 208). Probably the most definite thing known about kendrick's voyage northward in the autumn of 1789 is that both John Hoskins and Joseph Ingraham reported that they were told by Kendrick himself about troubles he had had with the natives of a village at Houston Stewart Channel at the southernmost part of the Queen Charlotte Islands (see Howay, Voyages, P. 240; and Ingraham, Voyage, PP. 179-181).

21 Howay, Voyages, P. 187.

${ }^{22}$ This was in honor of Dr. Thomas Bulfinch, a Boston physician (ibid., po 193). Today it is called Checleset Bay after its native name.

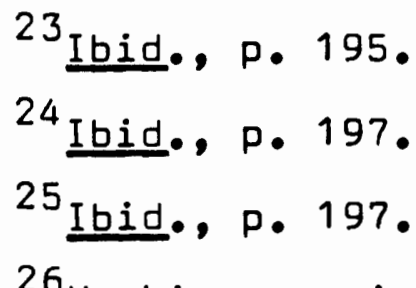

26 Hoskins surmised that Coya's loss of status was connected with troubles that had somehow erupted during one or both of two visits Kendrick had made to this location. They were told, Hoskins wrote, "by several of the natives, particularly a woman, who was very intelligible: 
that Captain Kendrick was here sometime ago in a vessel with one mast, and lately one with two; that he took Coya, tied a rope round his neck, whipt him, painted his face, cut off his hair, took away from him a great many skins, and then turned him ashore: Coya was now no longer a Chief, but an 'Ahliko', or one of the lower class" (ibid., p. 200). Later in August, 1791, Hoskins had an opportunity to talk with Kendrick at Clayoquot Sound, where the captain told his version of what happened. The theft of some linen during his visit in 1789 had led Kendrick to punish Coya and another chief by dismounting a cannon and clamping "one leg of each into the carriage where the arms of the cannon rest" until the purloined goods were restored. When Kendrick returned in June, 1791 , the natives attempted to seize his vessel (the sloop Washington rerigged as a brigantine with two masts) and in repulsing the attack many natives were killed (ibid., pp. 239-241). Joseph Ingraham claims that Kendrick told him in Macao that about 30 natives were killed in this episode (Ingraham, Voyage, pP. 180-181).

27 Howay, Voyages, P. 208. Boit's log adds that cloth also was used, but "Copper was not in demand" (ibid., p. 372).

\section{Ibid., P. 208.}

29 Ibid., Pp. 204-205. Just a few days earlier, on July 4, 1791, the Spanish explorer Manuel Quimper recorded seeing natives at Dungeness Bay on the Strait of Juan de Fuca wearing "English, Portuguese, and Chinese coins for earrings" (Wagner, Spanish Exploration in the Strait of Juan de Fuca, $p .109)$. In July of the following year (1792), another Spanish explorer, Jacinto Caamaño, recorded a more graphic description of the use of such coins by Cania, a chief at Parry Passage: "His clothing, all of sky-blue cloth, consisted of two loose frock coats one over the other, ornamented with Chinese cash, each one strung on a piece of sail-making twine with a large light-blue glass bead the size of a hazel nut loosely attached to the material, and together forming a button. His breeches, in the form of trousers, were also trimmed with many of these cash, so that he sounded like a carriage mule, as he walked" (wagner and Newcomb, "The Journal of Don Jacinto Caamaño,"

${ }^{30}$ The name is derived from a chief residing at the village on the inlet's north shore.

${ }^{31}$ Boit's 109 also fails to provide much detail, ex- 
cept to say that "we purchased a Good Lot of furs, cheifly for Iron and Cloth" (Howay, Voyages, p. 374).

${ }^{32}$ This area is also near one of the entrances to Behm Canal on the west side of Clarence Strait, where it will be recalled an exploring party of the Vancouver expedition was attacked in August, 1793 (see p. 103 of this study).

33 Howay, Voyages, p. 220.
34 Ibid., pp. $220-221$.
35 Ibid., p. $220, n \cdot 2$.
36 Hoskins says that second mate Joshua Caswell requested the captain's permission to take two men to catch fish in a nearby cove. Reluctantly, Gray acceded, and boatswain's mate John Folger and seaman Joseph Barnes accompanied Caswell on the fatal excursion. The site of this unfortunate event was later called Massacre Cove, and Howay believed it was probably located between Cholmondeley Sound and Skowl Bay on the west shore of Clarence Strait (see ibid., p. 221, n. 1).

37 Ibid., P. 222.

38 Ibid., P. 222. Boit, however, later considered the possibility that the kiliing of a number of natives by Captain Crowell of the brig Hancock may have also been a factor. Boit wrote: "Capt. Crowell had, upon some trifling offence, fir'd upon these Indians by which a number of them fell . - and perhaps this same fray was the means of our losing our worthy 2 nd officer as the places are not 20 leagues [roughly $100 \mathrm{~km}$. ] distant and mayhap they reck'd their Vengence upon us, thinking us all of one tribe. If it is so, bad luck to crowell. Amen" (ibid., p. 177).

${ }^{39}$ See pp. 103-104 of this study. It will also be recalled that Aleuts had stolen firearms from the Russians as early as 1764, and it is possible that the northern Tlingits could have obtained muskets in the same manner sometime before 1791 (see pp. 33-34 of this study).

$$
\begin{aligned}
& 40 \text { Howay, Voyages, pp. 230-231. } \\
& 41 \text { Ibid., p. } 214 . \\
& 42 \text { Ibid., p. } 235 .
\end{aligned}
$$


${ }^{43}$ The two ships had also met briefly on July 23 off the southern extreme of the Queen Charlotte Islands (see ibid., P. 209; and Ingraham, Voyage, P. 113). Voyage.

${ }^{44} \mathrm{An}$ account of the Hope's voyage is in Ingraham,

${ }^{45}$ Dixon's Cloak Bay, where Pérez had first anchored in 1774, and which was now (1791) apparently well known as a good location to obtain furs.

46 Ingraham, Voyage, p. 103. The reference apparently is to William Douglas, who commanded the Iphigenia Nubiana for Meares in 1788 and 1789, and who was on the coast as master of the Grace in 1790 and 1791 (see Howay, "A List of Trading Vessels," Transactions, 3rd series, 24 , sec. 2 (1930), pp. 119, 121).

47 Ingraham, Voyage, p. 105.

48 Ibid., pp. 105-106.

${ }^{49}$ Ibid., pp. 127-128. Elsewhere he says "five were deemed a $\frac{1 b i d}{900}$ 'day's work for our smith" (ibid., p. 120).

${ }^{50}$ It will be recalled that Caamaño saw them at Bucareli Bay $140 \mathrm{~km}$. north of Langara Island a year later (see p. 70 of this study).

51 Ingraham, Voyage, p. 192. The "leather for war garments" apparenthy were tanned "moose"--or more likely elk--hides that were exported principally from the vicinity of the Columbia River estuary (see Howay, Voyages, P. 260, n. 2). The "variegated shell" was from abalone brought by the Spanish from Monterey Bay, and which Pérez had originally introduced to the natives at Nootka Sound in 1774 (see Robert F. Heizer, "The Introduction of Monterey Shells to the Indians of the Northwest Coast," Pacific Northwest Quarterly, 21 (1940), PP. 399-402).

52 In just 49 days Ingraham claimed to have purchased "skins equal to 1400 sea otters, over 300 sables, and some beavers, wolverines, etc." (Ingraham, Voyage, P. xvii). Ironically, his success on the coast was not translated into the profits he had expected, for by the time he reached Macao the Chinese had suspended the fur trade because of a dispute with the Russians (see ibid., pP. 177-190).

$$
53 \text { Ibid., P. } 130 .
$$


${ }^{54}$ See p. 124 of this study; and Marchand, Voyage, P. 420.

\author{
${ }^{55}$ Ibid., P. 412 . \\ 56 Ibid., pp. 421-422.
}

57 The sloop, constructed from a pre-formed frame that had been carried aboard the Columbia, was launched in March, 1792 at Meares Island in a cove on Lemmens Inlet about 8 $\mathrm{km}$. northeast of Tofino, British Columbia (see Howay, Voyanes, pp. 275-276; and Samuel Eliot Morison, "The Columbia's Winter Quarters of 1791-1792 Located" "Oregon Historical Quarterly, 39, No. 1 (1938), pp. 3-7).

58 Howay, Voyages, P. 321.

59 Ibid., p. 326. This is close to the same location the washington had in 1789 purchased 200 skins "in a very fue moments for one chizel each."

60 Ibid., p. 345. The identity of this two-masted vessel is unknown, although Howay suggests at least three possibilities: the schooner Grace, master William Douglas (which apparently was sailing under the United States flag); the English brig Halycon, master Charles Barkley; and the English barque (rigged as a snow or a brig) Phoenix, under Hugh Moore.

61 The exact location of this rendezvous point, which they called Port Montgomery, has not been identified according to Howay, ibid., p. $327, n$. 1 .

62 Ibid., p. 351. Haswell says he had earlier (on June 18), at Checleset Bay on Vancouver Island, transferred to the Columbia "238 sea otter skins 142 Tails 23 Cootsacks and 19 Peices" (ibid., p. 337). Boit's 109 says the sloop "had collected about 500 Skins, all prime" (ibid., p. 405), but Haswell's figure would seem to be the more reliable one. In total, then, it appears that nearly five months of trading by the sloop, mostly in the vicinity of the Queen Charlotte Islands, had probably not produced much more than 300 sea otter pelts and certainly no more than 500. For comparison, it will be recalled that Ingraham had taken 1,400 sea otter skins in just 49 days during the summer of 1791 (see n. 52 above).

63 Haswell says they received 175 sea otter skins of superior quality" for the Adventure, minus her provisions and stores (see ibid., $p$. 355). Boit says they "sold the Sloop Adventure to the Spanish Governor [Juan Francisco de 
la Bodega y Quadra] for 72 Prime Sea Otter Skins worth 55 Dollars each in Canton which is equall to 4960\$, which at 50 per Cent advance home is 7440 Spanish Piasters, a good price" (ibid, pp. 416-417).

${ }^{64}$ On August 17, 1775, the Spanish frigate Santiago, under the command of Bruno de Hezeta, sighted the mouth of the Columbia River. Details of this discovery, however, were not generally available to English and American fur traders, and when Gray entered the river in May, 1792, he was almost certainly the first to do so. Meares had been off the river's mouth in 1788, but he thought it was merely a bay (which he called Deception), remarking that "we can now with safety assert that there is no such river as that of San Roc" (see Hezeta, "Diario," entry for August 17, 1775; and Meares, Voyages, P. 168).

65 Howay, Voyages, Pp. 394-395.

${ }^{66}$ Ibid., PP. 396-397.

67 Boit says they sold the sea otter furs at Canton for "90,000\$, average 45 Dollars each." From this it would seem they must have collected in total about 2,000 sea otter pelts, of which no more than about $650(500+75+75)$--and as few as $388(238+75+75)--c a n$ be directly attributed to the Adventure's voyage to the Queen Charlotte Islands and southeastern Alaska.

68 Ibid., P. 399.

${ }^{69}$ An account of this voyage is in the MS. Log of the Jefferson by Bernard Magee. A summary of the Log was published by $F$. W. Howay as "A Yankee Trader on the Northwest Coast, 1791-1795," Washington Historical Quarterly, 21, No. 2 (1930), pp. 83-94, which is the principal source for the discussion here.

70 Howay, "A Yankee Trader," P. 85.

71 Ibid, $\mathrm{P} .86$.

72 Ibid., PP. 86-87.

73 Ibid., P. 87. The "moose" skins were later found to be worth three sea otter skins in the North.

74 Between September 29 and October 23, the Resolution departed Barkley Sound on a trading voyage to the Columbia River, but weather conditions prevented her from entering the river. 
75 Howay, "A Yankee Trader," p. 87. This is probably the origin of a peculiar type of weapon mentioned by early visitors to the lower Columbia River and found there archaeologically at various locations. Lewis and Clark, in 1806 while at the Cathlahpohtle village $115 \mathrm{~km}$. upstream from the river's mouth, said the natives "have a number of large symeters of Iron from 3 to 4 feet long which hang by the heads of their beads [beds]; the blade of this weapon is thickest in the center tho' thin even there. [A]ll its edges are sharp and its greatest width which is about 9 inches from the point is about 4 inches. [T] he form is thus $\longrightarrow$ this is a formidable weapon" (Reuban Gold Thwaites, Original Journals of the Lewis and Clark Expedition, IV, 215). Further discussion of these weapons may be found in Vern F. Ray, "Lower Columbia Ethnographic Notes," University of Washington Publications in Anthropology, 7 , No. 2 (1938), P. 61; Luther S. Cressman, "Lower Columbia Indian Weapons," Oregon Historical Quarterly, 49, No. 4 (1938), pp. 297-298; and Roy F. Jones, Wappato Indians of the Lower Columbia River Valley, pp. 113-119.

76 Howay, "A Yankee Trader," pp. 87-88.

77 Dentalia or haiqua were eagerly sought by the Chinook at the mouth of the Columbia River, where they were obtainable only by trade from the North (see Verne F. Ray, "Lower Columbia Ethnographic Notes," p. 100).

$$
\begin{aligned}
& 78 \text { Howay, "A Yankee Trader," p. } 88 . \\
& 79 \text { Ibid., P. } 88 .
\end{aligned}
$$

80 In addition to Lewis and Clark, Gabriel Franchère (c. 1810) mentions that the weaponry of the Columbia River natives included "a sort of broadsword, the blade of which has two cutting edges about two and a half feet long and six inches wide" (Gabriel Franchère, Adventure at Astoria, p. 116). Such broadswords, however, were not reported by William Broughton when he conducted the first upriver expedition in 1792--which would be consistent with the time (April, 1794) at which the Resolution probably traded Robert's iron swords for elk skins (see J. Neilson Barry, "Columbia River Exploration, 1792," Oregon Historical Quarterly, 33, No. 2 (1932), P. 144).

81 Howay, "A Yankee Trader," p. 89.

82 Ibid., p. 89, refers to him only as "Captain Burling."

${ }^{83}$ The fate of the Resolution was later learned by 
Charles Bishop, captain of the English ship Ruby, through a chance conversation at Nootka with a certain Captain Barnett of an American ship named Mercury. Barnett claimed to have participated in the rescue of the schooner's one surviving crewman, and Bishop recounts the story in his journal (see Michael Roe, ed., The Journal and Letters of Captain Charles Bishop on the North-West Coast of America, in the pacific and New South wales, 1794-1799, pp. 95-99).

${ }^{84}$ Howay, "A Yankee Trader," P. 90.

${ }^{85}$ These varied articles are all mentioned in Magee's account according to Howay (ibid., Pp. 90-92). It is of some interest that during an archaeological investigation of a Haida burial shelter at Parry Passage two burial boxes were found to be of European manufacture. One was dovetailed construction and the other was a leather-covered trunk (see George F. MacDonald, "Haida Burial Practices: Three Archaeological Examples," Mercury Series, Archaeological Survey of Canada, Paper No. 9 , PP. 20,40$)$.

86 Howay, "A Yankee Trader," P. 92.

87 Roberts obtained a little more than Ingraham's 1,400 otter skins in 1791, but less than Gray's 2,000 pelts in 1792. Had the Resolution been able to rejoin and assist the Jefferson in the Queen Charlotte Islands during the summer of 1794 , the total might well have been higher. 
CHAPTER VIII

\section{MYTHS AND LEGENDS}

Native myths and legends contain clues that can assist in understanding the aboriginal possession and use of metals, the geography of native trading networks, and the first appearance of Europeans (and possibly Asians) among the native peoples of northwestern North America. Such orally transmitted stories are seldom literal accounts, and many of them no doubt interweave originally discrete events into a single narrative in which chronologic and geographic distinctions are blurred or lost. Nevertheless, they frequently seem to have some basis in an actual experience, event, or condition which, when distinguishable from mythic or legendary embellishments, can reveal valuable insights.

A story collected by anthropologist John R. Swanton at Sitka, Alaska, from a native named Dekinä́k! ' in 1904 describes one version of the origin of copper among the Tlingits. It alludes to the finding of "a copper canoe in which were wide seats," out of which its finder, a young boy living alone in poverty with his widowed mother in a house of branches 
began making a big house out of copper. He would pound out spears and bracelets under the branches. In those days there was no iron and copper. He also pounded out copper plates. Then he set them all round the inside of the house.

Then they threw the branch house away, letting the copper shine out. But his [dead] father had done this purposely to him in order to help him. So even now, when a man is poor something comes to help him. This shows how valuable copper was at the place where this happened. Even lately a copper plate use to cost two slaves. It has since become an everlasting thing (i.e., it is now used there all the time).1

This story lacks any chronologic or geographic reference, except that it was obtained from an informant at Sitka in 1904. Still, a few cautious conclusions are possible: the source of the copper appears to have had some association with water-borne transportation; it evidently was worked by cold-hammering methods; and the story treats copper as a symbol of wealth, implying its scarcity at some earlier (though uncertain) time.

Another story, obtained by Swanton (also in 1904) from a chief named Katishan at Wrangle, Alaska, tells of a man named Kake' q! Utê whose wanderings took him into the interior where he encountered eight Athapascans (Go' nana):

The men wore nice fur clothing and had their faces painted. Kakē'q! "tê became frightened and ran into the woods, leaving his fish roasting by the fire. Afterward the eight men acted as though they were calling him, so he climbed up into a tree and watched them. They did not know where he had gone. Then the men sat down and ate his fish, after which they stuck a copper-pointed arrow into the ground where each roasting stick had been. This was the first time a Tlingit had seen copper. ${ }^{2}$

The context of this episode provides only the vaguest hints 
as to its geographic location and chronology. Kake' $q$ ! Utê is said to have gone into the forest where he eventually "came to a big glacier, and walked along upon that," after which he travelled for some time, coming to a small creek. 3 It was at this point that the Athapascans were encountered. However vaguely located in space and time these events may be, Swanton's native informant did indicate that the story's hero belonged to a particular Tlingit group which elsewhere in the same story is given some geographic reference.

These people were the $L ! \bar{u} k ! n A \times A^{\prime} d \hat{i}$, who are described as having succeeded in laying "claim on the place where the copper plates come from." 4 The geographic particulars of their achievement are described in some detail:

Next spring the $L ! \bar{u} k ! n A \times A^{\prime} d \hat{i}$ went right to the mouth of Copper river. They made a village there at once and called it Kos! $\bar{e}^{\prime} \times k a$. . All along where they went they gave names. A certain creek was called $N A^{\prime} g A k U-h i n$ and they came to a lake which they named ktü'a [Lituya]. Then they went to a river called Alse' $x$ [Alsek], a the mouth of which they established a town and named it Kos!e' $x$. Afterward they went to the river from which the copper came and called it Iq $h \hat{i}^{\prime} n \hat{i}$ (Copper river). 5

This appears to describe a migration up the coast from Cross Sound past Lituya Bay, the Alsek River at Dry Bay southeast of Yakutat, and then beyond to the Copper River, between Prince William Sound and Cape Suckling. The association of this last river with the source of copper is very strong in Tlingit mythology. 6 
The myth of Kaké'q! Utê, as told by Swanton's informent, Katishan, also mentions another man of the $L ! \bar{u} k ! n A \times A^{\prime}$ dî named Cädis $\hat{i}^{\prime} k t c$, whose preparation for war with the Chilkat people is described as follows:

For Cādis $\hat{i}^{\prime} k t c ' s$ war hat they made a carving of a monster rat which is said to live under the mountain Was! $\bar{i}^{\prime}$ cá. His spear points they made out of iron--taken probably from some wreck. They considered themselves very lucky when they found this iron. They thought that it grew in the timber and not that it belonged to a ship. This they called Gaye's! hä' wu (Log of Iron). Gaye's was originally the name given black mud along the beaches to which people likened iron dust.

The belief that Northwest Coast natives may have first obtained iron from shipwrecked vessels thus has support in Tingit mythology.

A somewhat more specific instance in which iron was obtained from a shipureck is told in a Yakutat Tlingit story related by Frederica De Laguna:

The Calyix-Kagwantan had trouble among themselves. One group moved to Point Manby [the northwest point of Yakutat Bay]. The chief of the group made a lucky flower which helped them . . to find a ship on the beach. It was a Russian ship.

They found a woman there, the first white person they ever saw. They couldn't understand her. She tried to explain--pointed to herself and held up two fingers--that two white men with her had walked up that way. So the Indians looked and found their tracks. They tracked them because they knew they were in danger. They had fallen into the glacier and were dead.

So one of the men, Qátsxá, took the woman as his wife. They had a lot of things in that ship. They found iron and guns. They made a big bonfire and put the guns in it, and pounded it with stones to make spears out of it. She tried to show them how to use guns, but they didn't understand. The people 
became rich with all the things from the ship. They found some black powder and poured some water on it and tried to eat it. The woman tried to stop them. It was gunpowder.

The people knew how to work iron because they knew all about copper from the Copper River. They used to be able to make copper as hard as steel, for knives. Now, nobody knows how to do it. 8

While the location of these events seems clearly tied to Point Manby at Yakutat Bay, it is impossible to say with any certainty when they happened. The story is suggestive that a Russian vessel might have been wrecked at Yakutat sometime before the documented voyage of Izmailov and Bocharov reached there in 1788, but if so its identity remains unknown. 9

Far to the south of Yakutat Bay, $1,900 \mathrm{~km}$. away at the mouth of the Columbia River, a similar story was obtained by anthropologist Franz Boas in 1891 from Charles Cultee, a Clatsop Indian then living at Willapa Bay (immediately north of the river's mouth). Cultee recounted a story of how the Clatsop, a Chinook-speaking people who originally occupied villages on the south side of the Columbia's estuary, witnessed the first ship cast ashore in their vicinity. An old woman, walking on the beach north of Seaside, Oregon, saw something that she mistook for a whale, but

When she came near it she saw two spruce trees standing upright on it. She thought, "Behold! it is no whale. It is a monster." She reached the thing that lay there. Now she saw that its outer side was all covered with copper. Ropes were tied 
to those spruce trees and it was full of iron. Then a bear came out of it. He stood on the thing that lay there. He looked just like a bear, but his face was that of a human being.10

This description is of considerable interest since it indicates that the wrecked ship was copper-sheathed and had two masts. It is thus unlikely that the story can refer to an event much earlier than c. $1765,{ }^{11}$ and that the ship was most likely an English or American fur trading vessel-possibly the English snow, Sea Otter, commanded by William Tipping. 12 whatever its identity, the ship's copper sheathing and iron fittings would have been an abundant source of these materials. Moreover, if any of her crew survived, as the story suggests, their skills and knowledge would have been equally valuable.

News of the discovery spread among the clatsops, and They said, "What is it?" "Ah, something lies there and it is thus. There are two bears on it, or maybe they are people..." They reached the thing that lay there. Now the people, or what else they might be [i.e., the two castaways], held two copper kettles in their hands... Now the persons took their hands to their mouths and gave the people their kettles. They had lids. The men pointed inland and asked for water.. - One man [a clatsop] climbed up and entered the thing. He went down into the ship. He looked about in the interior of the ship; it was full of boxes. He found brass buttons in strings half a fathom long. He went out again to call his relatives, but they had already set fire to the ship. He jumped down - . It burnt just like fat. Then the Clatsop gathered the iron, the copper, and the
brass. Then all the people learned about it.

This section of the story suggests that iron, copper, and brass were either articles of great scarcity or substances 
unknown prior to this event, which would mean that the story must have been a recollection of something that happened before Gray first made contact with the Columbia River natives in May, $1792 .^{14}$ If there is merit in the suggestion that Tipping's vessel, the snow Sea Otter, was connected with this incident, the introduction of copper sheathing, together with brass and iron articles, among the Clatsops would thus seem to be fixed at c. 1786. Whatever the case, these materials must have first reached the Clatsops sometime between 1765 and 1792, if Cultee's story has its origin in an actual event.

The story's conclusion contains some additional clues as to the effect of this event on the clatsops, trade relations with their neighbors, as well as something of what happened to the two survivor:

The two persons were taken to the chief of the Clatsop. Then the chief of the one town said, "I want to keep one of the men with me." The people almost began to fight. Now one of them was taken to one town. Then the chief was satisfied. Now the Quenaiults, the Chehalis, and the Willapa went. The people of all the towns went there. The Cascades, the Cowlitz, and the Klickatat came down the river. All those of the upper part of the river came down to Clatsop. Strips of copper two fingers wide and going around the arm were exchanged for one slave each. A piece of iron as long as one-half the forearm was exchanged for one slave. A piece of brass two fingers wide was exchanged for one slave. A nail was sold for a good curried deerskin. Several nails were given for long dentalia. The people bought this and the Clatsop became rich. Then iron and brass were seen for the first time. Now they kept these two persons. One was kept by each chief; one was at the Clatsop town at the cape. 15 
Apparently the clatsops traded the exotic articles they obtained from the shipwreck to people who came from as far away as the Quinault River (130 km. northward up the coast) and inland from upriver locations $250 \mathrm{~km}$. to the east. 16 This trade was, moreover, of sufficient proportions to establish exchange rates equating metal articles with such aboriginal trade items as slaves, deerskins, and dentalia. It is interesting that Cultee's story distinguishes between copper and brass. ${ }^{17}$ In stating that as a result of this shipwreck "iron and brass were seen for the first time," there is a hint that copper was previously known to the clatsops. This would not be surprising considering the access the Tlingits had to copper from aboriginal sources, and the likelihood of trade connections between the columbia River and the North. Finally, it is apparent that the two survivors of this shipwreck remained with the clatsops for some indefinite time, perhaps long enough to be of service in putting this metallic bonanza to use.

We cannot be certain that this story is based on a single event--the story could be a composite of more than one shipwreck incident. Yet, it has a certain literal quality that suggests otherwise. Its contents seem to point fairly conclusively to events that must have happenbetween 1765 and 1792, and the number of unaccounted-for missing ships during that period--which were likely to have been off the Columbia River-ais too small to even 
suggest a multiplicity of such wrecks. ${ }^{18}$ whatever the exact origin of Cultee's account, it seems reasonably certain thay it was a memory of real events that introduced the Clatsops to large quantities of iron, copper, and brass --materials which were traded extensively up the coast and inland. 19

Myths and legends of this type among the Aleuts and Eskimos are not so evident, or they may have escaped attenion. The Russian explorer Gavriil Davydov, writing of the Kodiak Island natives (c. 1808), remarked that

In earlier years the Koniagas used as work tools a stone ax, sharpened shelis, or sharpened pieces of iron. This metal was known to the savages long before the arrival of the Russians; they occasionally found metal objects washed up by the sea, and prized them greatly. 20

Unfortunately, Davydov does not say what source or tradition led him to believe the natives had obtained iron before the appearance of the Russians. Anthropologist waldemar Jochelson speculated that such iron may have come "from the wrecking of European or Japanese ships," citing "an Aleut tradition quoted by [Ioann] Veniaminov which tells of a ship which brought iron to them." 21

Jochelson, who was writing c. 1910, had also come upon a curious story attributed by him to one A. Polonsky 22 concerning another native tradition:

An Aleut boy, who was taken in 1747 by Russian hunters from Attu to Kamchatka, reported that, as he remembered, men dressed in long many-colored silk and cotton clothing came to the island Attu in small 
ships with one sail; their heads were shaved to the crown and the hair on the back was plaited into tresses. Evidently these were Chinamen (if the report is correct). The same boy told that in former years a ship used to come to Attu, the men giving them iron, needles and leaf-tobacco in exchange for seaotter skins. 23

It will be recalled that the Russian vessel Evdokim, commanded by Mikhail Nevodchikov, did in fact visit Attu Island in 1745, distributing tobacco, needles, and Chinese (iron?) pipes among its inhabitants. 24 At least four Russian vessels are known to have sailed out of Kamchatka in 1747, one of which, the Ioann, fitted out by a certain Andrei Vsevidov, may have been at Attu Island. 25 It is thus conceivable that such a story could have been obtained under the circumstances described. But even so, can the story be taken as an indication that Chinese or Japanese vessels had previously been to Attu? A conclusive answer to this question, based on Jochelson's evidence alone, probably is not possible. Yet it will be recalled that when the Evdokim visited Attu Island in 1745-mthe first Russian ship to do som-an iron bolt was reportedly seen in the natives' possession. 26 The possibility that Chinese or Japanese vessels, coming from the direction of the Kuril Islands, visited or were shipwrecked in the westernmost Aleutians is by no means unlikely. If the story of this Aleut boy concerning visitors robed in "long many-colored silk and cotton clothing" has any basis in fact, it would have been a memory of events preceding 1745 by only a few 
years. Thus, this cannot be viewed as supporting claims made for Chinese voyages to North America before c. 500 A.D. 27 Nevertheless, it may be evidence--admittedly tenuous--that Aleutian natives had access to iron articles (as well as other materials) originating in Asia before 1745. 
261.

1 John R. Swanton, Tlingit Myths and Texts, pp. 258-

2 Ibid., P. 155.

3 Ibid., P. 154. Another version of this story, told by Dekina'k! U, Swanton's Sitka informant, says that

Kake' $q$ ! Utê (or, in that version spelled, Qate' q! Utế)

ascended somewhere towards the headwaters of the Alsek

River, which enters the ocean at Dry Bay, about $100 \mathrm{~km}$.

southeast of Yakutat Bay and heads at Aishihik Lake, about $300 \mathrm{~km}$. inland to the northeast of Dry Bay (see ibid., P. 330).

${ }^{4}$ Ibid., P. 160.

${ }^{5}$ Ibid., P. 160.

${ }^{6}$ Swanton's Sitka informant, Dekinā'k!u, interrupts one of his stories to remind his listener emphatically that copper came from the Copper River (ibid., p. 63).

${ }^{7}$ Ibid., p. 163.

8e Laguna, Under Mount St. Elias, I, 233.

${ }^{9}$ Makarova, Russians on the Pacific, p. 214, lists a vessel named Prokopii, commanded by Dmitrii Bocharov, as being wrecked in 1780, but this apparently occurred before the ship reached America.

10 Franz Boas, Chinook Texts, P. 277.

${ }^{11}$ The first European ship to be copper-sheathed apparently was the English frigate Alarm in 1761 (see Henry Hamilton, The Enqlish Brass and Copper Industries to 1800, p. 152, n. 2). According to the Oxford Companion to Ships and the Sea (Peter Kemp, ed., p. 777) junks were reportedly "seen sheathed in eastern watersin the early part of the 17 th century," although the exact nature of these sightings is not explained. The first copper-sheathed ship definitely known to have sailed the Pacific was the English frigate Dolphin, under John Byron, early in 1765 (see Beaglehole, The Exploration of the Pacific, pp. 195-196).

12 of 114 instances of fur trading vessels operating on the coast south of Sitka between 1785 and 1799 , all but four were English or American (although some sailed under Austrian, Portuguese, or Swedish colors to avoid seizure). Seventy-four of these instances involved ships of a type 
having two masts: 11 brigantines; 22 brigs; 23 snows; and 17 two-masted schooners (see Howay, "A List of Trading Vessels"). The English snow Sea Otter, under William Tipping (Meares' associate), disappeared without a trace in 1786, and she could have been the ship cast ashore at Clatsop. Even though she was last seen far to the north at Prince William Sound by James Strange, it is uncertain where she then sailed for or what her fate may have been.

\section{Boas, Chinook Texts, p. 278.}

${ }^{14}$ It will be recalled that when the Columbia entered the river's estuary, a brisk trade in copper, cloth, and iron spikes was conducted with the inhabitants at a village on the north shore, probably at the mouth of Grays River (see P. 146 of this study; and Howay, Voyages, pp. 396397). Thus, from historical sources, it is clear that the Columbia River natives were familiar with copper and iron by 1792 .

\section{Boas, Chinook Texts, P. 278 .}

${ }^{16}$ of the tribal groups mentioned in Cultee's account, the most distant to the north was the Quinault, a Salishspeaking people who lived in the vicinity of the Quinault River on the central Washington coast (see Ronald L. Olson, "The Quinault Indians," University of Washinaton Publications in Anthropolooy, 6, No. 1(1936), pp.10-14). The group coming from the greatest distance to the east was the Klickatat, a Sahaptin-speaking people who inhabited the north side of the Columbia River between 200 and $250 \mathrm{~km}$. upstream. They were active as middlemen in trade between coastal and interior peoples (see John R. Swanton, Indian Tribes of Washington, Oregon, and Idaho, p. 28; and Vern F. Ray, "Cultural Relations in the Flateau of Northwestern America," Publications of the Fredrick Webb Hodge Anniversary Publication Fund, $3, p .2)$. An interesting description of the native trade up the Columbia is contained in the journal of Charles Bishop, captain of the English ship Ruby. This ship spent the winter of 1795-1796 at the river's mouth (probably the first to do so), during which time Bishop was told by Concomly, a Chinook chief, that: "They [the Chinook] go up the River Chinook [Columbia] two or three hundred miles [326 to $489 \mathrm{~km}$ ] and come to Strange villages, where they land and offer trade with some trifling Pieces of Copper and Iron. The Strangers naturally demand more. The chief then gives the signal and they all discharge their Pieces laden with Powder, into the Air. These People never having heard or seen such a Strange Phenomena throw off their Skins and Leather War Dresses and fly into the woods, while the others Pick them up, and 
leave on the Spott the articles first offered" (Roe, The Journal and Letters of Captain Charles Bishop, pp. 118119). Archaeological work in 1948 at the McNary Dam site, $320 \mathrm{~km}$. upstream on the Columbia, revealed an abundance of iron, copper, and brass articles, many of which could be dated to the 18 th century and which were associated with a "people living during the earlier days of Indian-carried trade, in objects of White manufacture, up the Columbia" (see Douglas Osborne, River Basin Survey Papers No. 8 , Excavations in the McNary Reservoir Basin Near Umatilla, Ore-

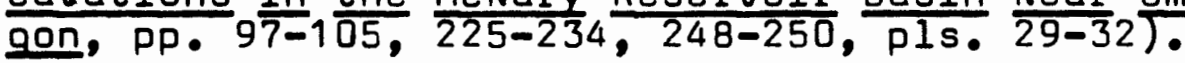

\section{${ }^{17}$ Brass is a yellow alloy consisting essentially of} copper and zinc.

18 Besides Tipping's Sea Otter, which disappeared in 1786, a Spanish ship was lost in 1769, giving rise to specualtion that she may have been wrecked on the Oregon coast (see S. A. Clarke, Pioneer Days of Oreoon History, P. 175). This latter vessel was the San Jose (also referred to as the Señor San Joseph and El Descubridor), a packetboat that was helping to supply the missions that had been established at San Diego and Monterey. The story of this missing vessel is told in Francisco Palóu's biography of Junipero Serra, where it is stated: "El Paquebot Señor San Joseph - - salió de Loreta. - el día 16 de Junio del mismo año; y no habiendose vueito a saber más de él, ni parecido fragmento alguno, se juzga padecería naufragio en alta mar" (The packetboat Señor San Joseph . - departed from Loreto [on the southeast coast of Baja California]. - on the 16 th of June of the same year [1769]; not having returned, nor knowing anything more of her, nor any fragment having shown up, it is judged she was shipwrecked on the high seas). See Francisco Paloú, Relación de la vida y apostólicas tareas del venerable padre fray Junipero Serra, p. 63. The san Jose was bound for San 0 iego and it is by no means impossible that she could have been carried north in bad weather and wrecked on the Oregon coast somewhere. Packetboats built at San Blas, Mexico, such as the San José, were similar to a brig and thus were two-masted. It is unknown, however, if she was copper-sheathed--a small likelihood considering she was not built in Europe (see Malcolm H. Kenyon, "Naval Construction and Repair at San Blas, Mexico, 1767-1797," PP. 122-123).

${ }^{19}$ It is interesting that no mention is made of trade with tribal groups to the south. From Haswell's account of the Washington's visit to the central Oregon coast in 1788 it is known that the natives south of the Columbia River possessed iron knives (Howay, Voyages, p. 33). Moreover, the Yuroks at Trinidad Harbor on the northern California 
coast had iron weapons as early as 1775, as the HezetaBodega expedition testified. There is thus some indication that the peoples south of the Columbia River may have been supplied with metal articles from a source distinct from the ship in Cultee's story. Some confirmation of this may be seen in the remark recorded in Hezeta's "Diario" that one of the Indians at Trinidad had obtained his iron knife by fabricating it from a spike that had washed ashore with wreckage from a ship (see Hezeta, "Diario," Jyne 18, 1775). Was this perhaps wreckage from the San José?

20 Davydov, Two Voyages, P. 186.

21 Waldemar Jochelson, History, Ethnology and Anthropology of the Aleut, $P .23$. Jochelson also comments (ibid., p. 22) that it is "possible the Aleut could have obtained Russian knives through intercourse with the Eskimos. Although, as it seems, there are no regular trade relations between the Aleut and Eskimo, in time of hostile engagements they could adopt some items of material sulture from each other."

$22 \mathrm{He}$ was apparently the author of a MS. entitled "List of Voyages of Russian Hunters in the Pacific from 1743 to 1800," which is said to be in the "Archives of the Geographical Society" (see Jochelson, History, p. 23, n. $3)$.

\section{Ibid., p. 23.}

24 See 29-30 of this study; also Makarova, Russians on the Pacific, P. 209; and Coxe, Russian Discoveries, PP. 31 32.

25 Details are sketchy concerning the Ioann's voyage. Makarova, Russians on the Pacific, $P .209$, says she left Kamchatka in 1747, returning in 1749 after visiting unknown locations. Coxe, Russian Discoveries, $P .38$, also says the Ioann left in 1747 , and that she returned on July 25 (0.5.?), 1749, after "having probably touched upon one of the nearest Aleutian Isles which was uninhabited." The other three vessels that sailed in 1747 are believed to have gone to Copper or Bering islands (see Makarova, Russians on the Pacific, P. 209\%.

${ }^{26}$ See $P .30$ of this study; also Coxe, Russian Discoveries, P. 34 .

27 See, for example, Henriette Mertz, Gods from the Far East: How the Chinese Discovered America Toriginaliy published as pale Ink). 


\section{CHAPTER IX}

\section{MATERIALS FROM ASIA}

There are abundant indications in the historical record and, to a lesser extent, in native oral tradition, that European cultural materials were reaching North America's northwestern coasts independent of the fur trading activities initiated by the English in 1785. We know, of course, that exploring vessels between 1741 and 1779 , such as those of Bering, Chirikov, Levashov, Krenitsyn, Pérez, Hezeta, Bodega, Cook, and Arteaga, brought such materials, and that the fur collecting activities of the Russian promyshlenniki in the Aleutians provided another source, beginning as early as 1745. Dccasionally, a shipwrecked European vessel may have unexpectedly made an involuntary contribution.

In 1939, a comprehensive investigation of the use of iron and copper among the natives of British Columbia by T. A. Rickard suggested that such metals could have been obtained through the hitherto overlooked process of wreckage caught in the Kuroshio and North Pacific currents drifting across the open ocean--sometimes over great distances--and bringing with it miscellaneous nails, spikes, bolts, etc. ${ }^{1}$ This source, Rickard argued, together with 
native sources of copper in the Copper River basin, could have theoretically supplied metals to Alaskan and Northwest Coast natives long before any European came near the region. Rickard's so-called "drift iron" theory is plausible, and it has been embraced by anthropologists such as Erna Gunther and De Laguna as an explanation of pre-European iron among Alaskan and Northwest Coast natives. 2

Others have been less certain. Philip Drucker, for example, countered:

Some ethnologists and historians have suggested that this pre-European iron may have been found in the form of spikes, etc. from the wreckage of ships washed on the beaches by the Japanese Current, and there is evidence that such "drift iron" was used in early historic times. However, few vessels in which iron spikes and bolts were commonly used were sailing the western Pacific before Cook's day. It is more likely that the same Siberian Iron Age center that provided the Punuk culture [at st. Lawrence just south of bering Strait] of the archaeologically ancient Alaskan Eskimo with metal was the ultimate source of prehistoric iron tools on the Northwest Coast.

Elsewhere Drucker cites pre-European iron as evidence of

trade connections with Asia through Eskimo and Aleut. Iron, in small quantities, used for cutting tools

first appears in Eskimo culture in the horizon designated "punuk," after the St. Lawrence Island site where it was first identified, dated at about 1000 A. D. The iron tools that the first European explorers like Captain Cook observed on the Northwest Coast, and the obvious familiarity with the material that led to its demand by the natives in exchange for their furs, mean that the trade connections continued up to the historic period. 4

What about the origin of pre-European iron in Asia? Did trade connections exist across the Bering Strait or between Kamchatka, the Kuril Islands, and the Aleutians? 
Were non-Europeans such as the Chukchi engaged in trade, as Steller thought, that eventually supplied the natives of the Shumagin Islands with iron knives? Or, as the story Jochelson heard suggested, had Japanese or Chinese sailed to the Aleutian Islands on trading ventures? For that matter, were there perhaps other sources overlooked entirely in these speculations? These are not questions upon which the available historical sources shed much light, although some remarks contained in Stepan Krasheninnikov's account of Russian explorations in Kamchatka in the early 18 th century ${ }^{5}$ are relevant and offer a good point of departure.

Krasheninnikov, who was a student assigned to Bering's second Kamchatka expedition, spent nearly three years exploring and observing Kamchatka and its inhabitants

first-hand between 1737 and 1740. In recording his observations of the Kamchadal people, he wrote:

It would be interesting to know how these people who have no knowledge of metals, and are indeed ignorant, backward and too stupid to count beyond ten, have nevertheless succeeded, without the help of any iron implement, in chiseling, carving, cutting, splitting and sawing wood, building homes, making fire and cooking their food in wooden vessels. Necessity is the mother of invention, and man discovers resources in himself when he must satisfy his needs. 6

The answer to this seeming puzzle, however, was that the Kamchadals did in fact possess and use some iron implements. Besides learning that the natives "have the skill to make spears and arrows out of the pots and kettles which 
they buy," Krasheninnikov was surprised to hear rumors

that the Kamchadals understood how to use iron before the Russians came; that they owed this skill to the Japanese who live near the Kurile Islands, that these people even came once by sea to the mouth of the Bolshaia [a river on the southwest coast of Kamchatka], and that the name shishaman given to them by the Kamchadals is derived from shish, which means a small needle for sewing.?

He remained skeptical of the likelihood that Japan-

ese vessels had actually reached Kamchatka, writing that

There is no doubt that the Japanese used to come regularly to the Kurile Islands in small boats to trade, as I have bought from Kamchadals some silver earrings, a Japanese saber, and a lacquered tray used for serving tea, which could only have come from Japan. But it is not certain that any of their boats ever appeared at the mouth of the Bolshaia River; it is hard to believe that they would subject themselves to so much difficulty and danger by navigating in unknown territory.

Yet Kraheninnikov himself reported that in 1729 a Japanese vessel "was cast up on the shore of Kamchatka, between Cape Lopatka and Avacha." 9 And, in fact, there is solid evidence that a Japanese ship was wrecked in Kamchatka as early as 1696, since one of the survivors of the shipwreck, known as Dembei, was sent to European Russia by Volodimer Atlasov, an explorer of the Kamchatka Peninsula in the 1690s. Atlasov mistakenly thought the castaway was from India and thus did not connect him with Japan. It was only later, towards the end of 1701 or early in 1702, when Dembei was brought to Moscow that it was finally discovered that he was Japanese. 10 Krasheninnikov apparently was unaware of Dembei or the shipwreck in which he had been in- 
volved.

Forced to concede reluctantly that the Japanese had reached Kamchatka, Krasheninnikov nevertheless continued to insist that such cases did not constitute "organized trade." He believed the Japanese maintained regular trade contacts only with the Ainu inhabitants of the Kuril Islands, despite rumors that "for more than 150 years there have been trade relations between the Kamchadals and the Japanese [in which] the latter gave them all sorts of iron and copper vessels and needles and knives in exchange for furs." 11 Assessing the accuracy of these rumors as well as the reliability of Krasheninnikov's judgement is difficult. Still, there is enough here to suspect that Japanese trade goods were moving northward regardless of how indirect, infrequent, or little organized Japanese contacts with the Kamchatkan natives may have been. The mechanism of this flow even bears some resemblance to what happened on the opposite side of the Pacific where trade goods, sold by Anglo-American maritime fur traders, moved through the native trade network considerable distances away from where they were originally introduced, increasing in value as they went. In other words, direct or "organized" contacts between aborigines and foreigners need not have occurred everywhere trade articles appeared. What evidence is there that Japanese or Chinese trade materials may have found their way into North America inde- 
pendent of ocean drift, Russian activity in the Aleutians, or the Anglo-American fur traders operating out of Asian ports such as Macao, Canton, Calcutta, and Bombay? Clearly any object that might qualify would have to have been of Asian manufacture, made before 1741, and found or reported under circumstances precluding its introduction at some later date or by ocean drift. Finding articles of the right manufacture and age is not difficult, but the circumstances of most finds (except under the most rigorous archaeological control) are seldom unambiguous enough to preclude other sources.

By far the most numerous objects meeting the criteria of age and manufacture are Asian coins. It will be recalled that reports of "Chinese coins" or "China cash" are met with in the journals of at least four 18th century visitors to the Northwest Coast. ${ }^{12}$ The coins seen in these instances cannot be dated, except to say they could not have been more recent than China's Qian Long period (17361795). We also know that in three of these reports there are circumstantial indications that the coins probably were traded by Anglo-American maritime fur traders. Only the sighting at Yakutat Bay by James Colnett in 1788 is 1ikely to have represented coins obtained from some other source. There is some possibility that the coins Colnett saw could have come from a Chinese or Japanese vessel operating in the Aleutians, having been eventually traded eastward, or 
alternatively from such a vessel blown off course and wrecked somewhere near Yakutat.

In the 19 th and 20 th centuries there have been numerous reports of Asian coins found in Alaska, British Columbia, Oregon, and Washington. 13 while claims of great age have sometimes been made for these coins (some as early as the 2nd century B. C.), such claims are mostly exaggerated or unfounded. 14 The two oldest examples that can be reliably dated are from the period C. 1078-1125 A. D. during the Song dynasty. 15 Most, however, date from the Qing dynasty (1644-1911) with perhaps a handful from the preceding Ming dynasty (1368-1644). A few Japanese coins have also been reported of which at least one is reliably dated to 1668.16 Part of these coins almost certainly fell into native hands before the historic period of Chinese immigration began c. 1850. While the maritime fur trade no doubt was a principal source of such coins before 1850, little is known about exactly when or how they were actually distributed.

There is one case, however, reported by anthropologist Frederica De Laguna, that is especially interesting and which may come as close as any to supporting the thesis that Asian materials were entering North America before 1741. During an archaeological survey in the early 1950s of Chugach sites at Prince William Sound, Alaska, De Laguna uncovered a Chinese coin on the north shore of Hinchin- 
brook Ieland. 17 The coin, which was dated to the Kang $X_{i}$ period (1662-1722) of the Qing dynasty, came from "just under the turf" at a site with late prehistoric cultural associations. No claim of great antiquity was thus made, but De Laguna wondered if this coin, together with the blue beads and iron reported by Cook in 1778, might be evidence of what she termed a "protohistoric" period beginning sometime in the late 17 th or early 18 th centuries and continuing until 1783, when Zaikov's expedition initiated the "historic" period at Prince William Sound. 18 De Laguna also reported that she had been told by the "natives at Chenega [a village on the west side of Prince william Sound] that they formerly wore coins of this type hung from holes in the ears or nose." 19

The existence of blue glass beads and iron among the Chugach prior to the first recorded European contact is well attested by Cook's account. The circumstances of the Chinese coin found by De Laguna suggests that it (and others like it) could have been obtained at the same time or from the same sources as the beads and iron. Unlike the beads and iron, we know the period in which the coin was manufactured, so if it did indeed reach the Chugach before 1778, it could not have been earlier than 1662. We also know that by 1788 similar coins were seen sewn on the clothing of a native at Yakutat Bay, $400 \mathrm{~km}$. to the east. Since there is no specific documentary evidence to indicate 
that English or Russian fur traders at Prince William Sound or Yakutat Bay between 1783 and 1788 employed Asian coins in trade, it remains an open question as to how or when such coins fell into native hands.

Another instance of Asian coins found in Alaska that deserves attention concerns a wooden mask obtained c. 18831885 from an Indian grave at Chilkat village. 20 This mask, according to a U. S. Navy lieutenant named T. Dix Bolles who reported the find, "has for its eyes two large bronze Chinese Temple coins." 21 The circumstances of the find led Bolles to believe the mask may have been as much as two hundred years old. He wrote:

From the [grave] in which the mask was found we got very little, its contents having nearly all rotted completely away, the mask in question being better preserved than the rest by a loose cedar board which protected it from the rain which leaked through in other places. The mask is skillfully carved from cedar wood and painted in the usual grotesque manner, but with strickly native colors.... Upon casual inspection this mask does not show age, but, examined more closely, the wood is seen to be affected with dry rot, while the surface seems to have been protected by the paint which was probably mixed with fish oil.

The grave in which this mask was found was pointed out to me as being old, and that of a medicine man who had flourished more than two hundred years ago, six successors having filled this office; each one living to a good old age. . . When the coins were shown to the native Chilkats they could not remember having ever seen such objects before.

- - I - - confess that I see no other possible conclusion to draw than that these coins were obtained two hundred years ago, and the natural surmise is that they came from a junk driven on the coast, Chinese most likely, as the Japanese would probably not 
have two such coins. 22

The coins on this mask, while almost certainly of Chinese origin, differ from the coin found at Prince william Sound. Unlike the latter, the Chilkat coins are so-called "temple coins" or amulets and do not bear inscriptions by which they can be dated. 23 Thus, while it may well be that the Bolles mask and coins could be 200 years old, that has not been confirmed by dating the coins themselves. If there is any truth in Bolles belief that the coins were obtained 200 years earlier, that would place their introduction c. 1683-1685--a time consistent with the "protohistoric" period posited in De Laguna's Chugach chronology.

The two preceding cases involve only three coins in total, hardly enough to suggest that Alaskan natives had access to an abundance of Asian coins. The accounts of 18 th century voyagers nevertheless speak unmistakably about such coins being possessed by the natives in some quantities. This can in fact be confirmed by reference to a Tlingit leather-armor vest that was catalogued by the Smithsonian Institution in 1870.24 This vest is literally covered with at least 214 Chinese coins (those visible in a photograph) of which 152 can be identified. Among the identifiable coins, all but six were from the first three Qing reigns, i.8., 1644 to 1735. It may also be of significance that the numbers of these coins by reign period fluctuate 
roughly in proportion to the length of each reign period, except in the case of the most recent (Qian Long) coins. This is shown as follows:

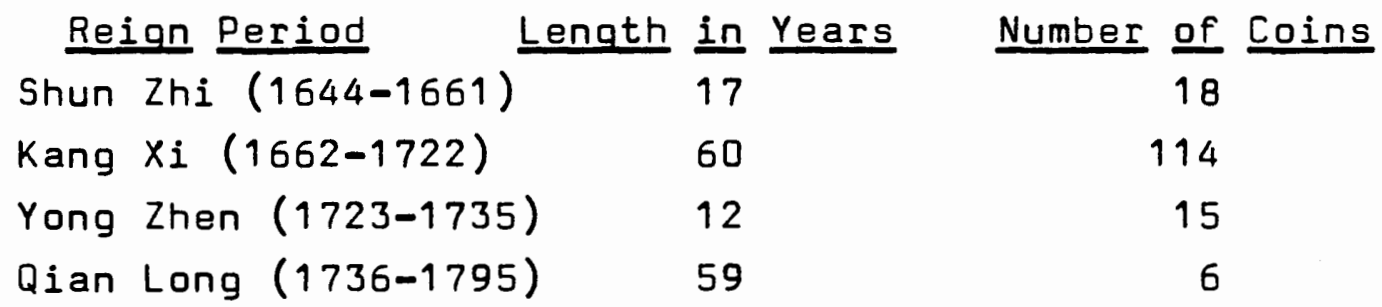

This pattern appears to suggest that most if not all of the coins were obtained in the 18 th century, possibly before or during the early years of the Qian Long reign. If the coins were obtained late in the 18 th century or after 1800 , it is strange that what had become by then the lengthy Qian Long period was not better represented numerically. This line of reasoning tentatively points to the period between c. 1650 and 1750 as the most probable time during which these particular coins were acquired.

Coins are by no means the only materials of Asian origin that have been reported from the Alaskan and Northwest coasts. In 1894, Franz Boas visited a village called Kincolith at the mouth of the Nass River in northwestern British Columbia. 25 There he was shown an unusual bronze figurine that was then in the possession of a Rev. W. H. Collison. Boas described the circumstances of the find: According to the testimony of Mr. Collison, which was borne out by remarks of Indians who had seen the object, the same was found in digging over a potatopatch on a place which had formerly been covered with heavy timber. It does not seem at all likely that 
the specimen should have got into this position recently. 26

A photograph and cast of the object were submitted by Boas to Professor Albert Grünwedel of Berlin, who identified it "as the handle of a ghantâ, which is a bell used by the Brâhmana in the Pûja ceremony."27 A number of such bells were, according to Boas, in the collection of the Royal Ethnological Museum in Berlin, which had come from the Indian states of Bengal and adjacent Orissa, and the Himalayan kingdom of Nepal. It was by comparison with the handles of these bells that Grünwedel identified the object from Kincolith village. The figure on the handle is probably a Garuda, a winged creature of Hindu mythology. As to the age of the object, Grünwedel could be no more definite than to say that "it may be a hundred years old or a little older." 28

Boas speculated that the object might have somehow been connected with a Spanish vessel engaged in the trade between Manila and Acapulco. 29 A somewhat more likely possibility--although equally speculative--is that this object was carried to North America in 1786 aboard either Meares' ship, the Nootka, or Tipping's Sea Dtter, both of which sailed from Calcutta in Bengal. Of these two, Tipping's ship is perhaps the more likely possibility, since Meares is not known to have visited in 1786 any locality within $1200 \mathrm{~km}$. of the Kincolith village. On the other 
hand, Tipping's movements on the coast that year are an open question, and the figurine Boas saw at the Nass River could be evidence that the Sea Dtter headed south after leaving Prince william Sound. 30 It is also conceivable that one of James Strange's ships in 1786, the Captain Cook or Experiment, might have carried such an object, since they also sailed from India. Their port of embarcation, however, was Bombay on the opposite side of the Indian subcontinent from Bengal and Orissa. Strange also is not known to have traded with the natives any closer than within $450 \mathrm{~km}$. of the Nass River. 31 In any event, this curious object is not likely attributable to the Manila trade, ocean drift, or whatever trade in the North may have otherwise figured in Asian materials reaching North America. It seems most likely that it simply is an example of the unusual objects that vessels engaged in the post-1785 fur trade could sometimes bring with them.

Asian ceramics are another category of material that seem to have reached Alaska and the Northwest Coast in the 18th century. It will be recalled that when Chirikov's Sv. Pavel was at Adak Island in the Andreanof group of the Aleutians one of the the objects the Russians tried (unsuccessfully) to interest the natives in was a "Chinese cup." 32 That was in 1741, and while traffic in such articles does not appear to have been great, it is possible that later Russian promyshlenniki could have also used 
similar ceramic items in trade--presumably with better success. Shelikhov's reference to burying pieces of pottery in 1786, apparently as a means of supporting Russian claims in Alaska, suggests that ceramic materials of some kind were brought to America by the Russians. 33 Archaeological evidence of this, however, is scanty if not absent. Sherds of Chinese porcelain were reported by De Laguna at a Yakutat Bay site, but they were identfied as "later than Canton ware - - similar to that introduced into California about 1850." 34 So presumably these fragments were unrelated to events in the 18th century.

South of Alaska, however, there is archaeological evidence that Chinese porcelain articles reached the Oregon coast in the 18 th century and very likely even earlier. Between 1956 and 1958, an archaeological site designated 35-TI-1, at the Netarts Sand Spit on the northern Oregon coast, was excavated under the direction of L. S. Cressman of the University of Oregon. In 1958, work on "House 13" of the site, under the supervision of Thomas M. Newman, uncovered 127 fragments of Chinese porcelain. 35 These fragments were at first thought to have been manufactured during the Qian Long period (1736-1795) of the Qing dynasty and obtained by the native inhabitants of the site sometime in. the last decade of the 18th century. A recent (1981) reëxamination of these porcelain sherds, however, suggests that they are of earlier manufacture, probably dating from 
sometime between the Wan Li period (1573-1619) of the Ming dynasty and the Kang $X i$ period (1662-1722) of the Qing dynasty. This has thus raised again the question of how and when these particular Asian materials were obtained by the natives at the Netarts Sand Spit. 36

The earliest historic contact with the Tillamook Indians of the northern Oregon coast was made by Gray's sloop, the Lady Washington, in mid-August, 1788. There is no indication that Chinese porcelain wares were traded to the natives at that time, nor is it likely that Gray or his crew would have used such items in trade since they had sailed directly from Boston and had not yet been to the Far East. While it is conceivable that some other fur trader sailing out of an Asian port could have been responsible, or that the porcelains were obtained through indirect trade, these seem unlikely possibilities. Unless the items were traded as fragments per se, it is difficult to believe that intact porcelain wares, manufactured before c. 1720 and having considerable value in late 18th century European, American, or even Chinese markets, would have been used for trade with the natives. 37

There are at least two other general explanations that have been advanced to account for the introduction of Chinese porcelain on the Oregon coast well before the period of historic contact. One possibility is that a derelict Chinese or Japanese vessel was cast ashore at or near 
the Netarts Sand Spit, presumably after making an involuntary drift voyage across the ocean in the grips of the Kuroshio and North Pacific currents. In January, 1834, just such a derelict Japanese junk was wrecked at Cape Flattery on the northern Washington coast. Thres of its crewmen survived, and they together with the ship's cargo -which included ceramic wares (possibly porcelains)--fell into native hands. 38 It is not likely that this particular event was connected with the Netarts porcelains, but it does illustrate the plausibility of this explanation.

A second theory concerns the Manila ships that franz Boas thought might have been the source of the figurine at Kincolith village in British Columbia. Over the two and a half centuries they sailed, many of these ships were lost, usually under circumstances that were well known at the time or which later came to light. In a fow cases, however, they disappeared without anything ever turning up as to their fates. Two such ships were the San Antonio in 1604,39 and the San Francisco Xavier (commanded by Santiago Zabalburú) in c. 1705,40 both of which vanished at sea without a trace attempting to cross the North Pacific. Their respective disappearances coincide broadly with the Ievised dates (1573-1722) now thought to bracket the porcelains found at Netarts. Since their eventual fates are unknown, and Chinese ceramics (including porcelain wares) were commodities in the Manila trade, 41 the San Antonio 
and Xavier have come to be considered as possibly responsible for depositing Chinese porcelains on the Oregon coast. 42

Besides the finds of porcelain, beeswax, another important commodity in the Manila trade, has also been frequently reported from the vicinity of Nehalem Bay (about $30 \mathrm{~km}$. north of the Netarts site) on the Tillamook County coast. $^{43}$ Perhaps the largest and best-known example of this material is in the Tillamook County Pioneer Museum. In 1961, this particular piece of beeswax was subjected to radiocarbon dating tests with results that indicated its age to be " 280 years old, plus or minus 110 years, with a 95 percent confidence of accuracy." 44 If correct, this meant that the beeswax probably had been collected c. 1680, which is a time reasonably consistent with the disappearance of the Xavier in c. 1705--although, curiously, a full 25 years prior to the ship's departure from Manila. New light on the dating of the Nehalem beeswax, however, has emerged from a recent (1982) re-testing of the Tillamook Museum's specimen using radiocarbon dating methods considered improved over those available in 1961. These new results suggest the beeswax was more likely collected $c$. 1570, and that it was almost certainly not collected after c. 1650.45 This raises anew the question of how and when this material reached the Tillamook coast, since it widens the gap between it and the time the Xavier sailed to more 
than 50 years and perhaps as much as a century or more.

Manila galleons that disappeared in the late 16th century may now take center stage in this issue. Perhaps the one of most interest is the San Juanillo (commanded by Juan de Ribera), which was dispatched to New Spain by the governor of the Philippines, Francisco de Sande, in 1578. "This ship," according to Antonio de Morga, a colonial official at Manila in the late 16th century, "was lost at sea and nothing more was ever heard of her." 46 The disappearance of the San Juanillo falls about eight years after the most probable time the Nehalem beeswax was collected (c. 1570, as newly determined), and thus their correlation is surprisingly close. Such a date (c. 1578) is just within the earliest range of the Netarts porcelains (c. 1573), and not all of those materials can be conclusively dated that early. But the wide range of the porcelain dates is due in part to uncertainties in the methods available to arrive at their probable age. Moreover, there is always the chance that more than one of these ships--the San Juanillo (1578), San Antonio (1604), and San Francisco Xavier (c. 1705)--could have been wrecked on the northern Oregon coast.

The large quantities of Asian commodities carried by any one of these ships, 47 to say nothing of the iron, brass, and copper fittings they were equipped with, would have been a major source of both Asian and European mater- 
ials of a wide variety. Chinese vessels plying between the Philippines and mainland Asia, and Japanese or Portuguese merchantmen sailing between Manila and Nagasaki were similarly laden with exotic goods. Among other things, Morga mentions "manufactured wax . . and china jars for keeping their tea in" as commodities in the Nagasaki-Manila trade. 48 Although the Chinese, Japanese, or Portuguese ships engaged in the Manila trade did not intentionally set out for North America, a disabling storm and the Kuroshio and North Pacific currents were capable of bringing them there. During the first half of the 17th century ships of Dutch nationality also were active in this trade, although primarily as interlopers in competition with Iberian shipping. 49 Any of these ships had the potential of inducing a veritable minor revolution in material culture--even if only temporarily--among the natives who by chance may have been the unintended beneficiaries of the Manila trade. And there is now some indication that this may have happened much earlier than has hitherto been supposed. 50 
${ }^{1} \mathrm{~T}$. A. Rickard, "The Use of Iron and Copper by the Indians of British Columbia," British Columbia Historical Quarterly, 3, No. 1 (1939).

2 See Erna Gunther, Indian Life on the Northwest Coast of North America, PP. 249-251. De Laguna, Archaeology of the Yakutat Bay Area, P. 219, has interpreted some of the iron objects in aboriginal archaeological contexts at Yakutat Bay as "drift iron."

44.

${ }^{3}$ Philip Drucker, Indians of the Northwest Coast, $P$.

${ }^{4}$ Ibid., P. 190.

5 Stepan Krasheninnikov, Explorations of Kamchatka.

Ibid., P. 216.

Ibid., P. 217.

8 Ibid., P. 217.

9 Ibid., P. 315. His account also implies that other Japanese vessels had been wrecked in Kamchatka, since he alludes to "gold, in bullion and small pieces, marked with a Japanese seal - . found on the Japanese ships which had been wrecked on the coast of Kamchatka" (ibid., pp. 312-313). Besides the wreck of 1729, Brooks, "Report of Japanese Vessels Wrecked," P. 9, lists similar wrecks in 1694 and 1710.

Pp. 26-30.

${ }^{10}$ See George Lensen, The Russian Push Toward Japan,

11 Krasheninnikov, Explorations, P. 365.

${ }^{12}$ They were: James Colnett at Yakutat Bay in southeastern Alaska (1788); John Hoskins at Houston Stewart Channel, Queen Charlotte Islands (1791); Manuel Quimper at Dungeness Bay, Strait of Juan de Fuca (1791); and Jacinto Caamaño at Parry Passage, Queen Charlotte Islands (1792).

13 Reports of such finds in Alaska are in T. Dix Bolles, "Chinese Relics in Alaska," Proceedings of the U. S. National Museum, 15, No. $1(1892)$, P. 221; De Laguna, Chuqach Prehistory, PP. 219-221; and George Phebus, "ikonapee's Money? Elicits Smithsonian Response," Screenings, 23. No. 2 (1974). British Columbia finds are discussed in 
a three-part article by Grant Keddie entitled "Evidence of Early Chinese Artifacts in British Columbia?" The Midden, 12, No. $5(1980)$, and 13, No. 2 (1981). Part three was in MS. as of spring, 1982. Asian coins found along the Columbia River in Oregon and Washington are discussed in Herbert $K$. Beals, "Chinese Coins in Six Northwestern Aboriginal Sites," Historical Archasology, 14 (1980), pp. 5872: also see Beals, "Chinese Coins: New Evidence," Screenings, 26, No. 8 (1977); John Woodward and Beals, "Fur Trade Symbols: A Glimpse from the Gladstone Graves," Proceedings of the First Annual Symposium of the Association of Oregon Archaeologists, Occasional Papers No. 1 (1980); nd Beals, "The Distribution and Use of Asian Coins as Trade Items on the Northwest Coast of America," Contributions to the Archaeology of Oregon, 1981-1982, Occasional Papers No. 2 (1983).

${ }^{14}$ See Keddie, "Evidence of Early Chinese Artifacts in British Columbia?" for a discussion of how such exaggerations occurred.

${ }^{15}$ The oldest Chinese coin reported from British Columbia in an aboriginal archaeological context was found at Chinlac village in the province's central interior. The coin was dated c. 1125 A. D. (see Keddie, "The Reliability of Dating Archaeological and Ethnographic Materials with Associated Chinese Coins," Datum, 3, No. 2 (1978). Another coin, reportedly found in an Indian grave on the Clackamas River in Oregon, has been dated at 1078-1085 A. D. (see Beals, "Chinese Coins: New Evidence," Screenings, 26, No. 8).

${ }^{16}$ This coin reportedly came from an Indian grave also on the Clackamas River in Oregon (see Woodward and Beals, "Fur Trade Symbols," p. 120).

${ }^{17}$ De Laguna, Chugach Prehistory, pp. 220-221. This island is located at the eastern entrance to Prince william Sound. The site, designated "No. 7" by De Laguna, is situated on a channel known as Hawkins Cutoff that separates Hinchinbrook and Hawkins islands.

18 Ibid., pp. 64-65. Apparently De Laguna did not consider the brief contact made by Cook in 1778 sufficient to rate that the beginning of the "historic" period. She posited a chronological scheme for the Prince William Sound sites consisting of four components: (1) older prehistoric; (2) younger prehistoric; (3) protohistoric; and (4) historic. The layers below the turf at Site No.? were assigned to the younger prehistoric, and the turf itself tentatively to the protohistoric. She considered 
the "Cook type" beads diagnostic of the protohistoric component, elsewhere suggesting (ibid., $p .62$ ) that these beads themselves may have been of Chinese manufacture.

${ }^{19}$ Ibid., P. 219.

20 This Tlingit village was located at the mouth of the Chilkat River near Haines at the north end of the Lynn Canal in southeastern Alaska.

21 Bolles, "Chinese Relics," P. 221. This mask has recently (1980) been featured on a $U$. S. stamp.

22 Ibid., P. 221.

23 Only one side of these coins is visible in photographs of the Bolles mask. One coin has what appears to be a Phoenix bird and the other a dragon--both common motifs in Chinese art. The inward-facing sides of the coins could have inscriptions, but they are not visible. The coins have round central holes and measure about $50 \mathrm{~mm}$. in diameter. A drawing of the coin from Prince william Sound in De Laguna's Chugach Prehistory, P. 220, shows only the obverse face which bears the inscription of the Kang $X i$ period. It has a square central hole.

${ }^{24}$ See Phebus, "'Konapee's Money?' Elicits Smithsonian Response." There apparently is no information on the exact locality from which this vest was obtained.

${ }^{25}$ The Nass River empties into Portland Inlet about $75 \mathrm{~km}$. north of Prince Rupert, British Columbia. Kincolith village is about $17 \mathrm{~km}$. from the Alaskan border.

26 Franz Boas, "A Bronze Figurine from British Columbia," American Museum of Natural History Bulletin, 14 (1901), p. 51 .

27 Ibid., P. 51.

${ }^{28}$ Ibid., P. 52. This would have dated the object to the last two decades of the 18th century.

${ }^{29}$ Spanish ships, known as naos de China or Manila galleons, annually sailed between Manila and Acapulco from 1565 to 1815. Their eastward course carried them across the North Pacific at latitudes as high as $400 \mathrm{~N}$., and several of them disappeared at sea without a trace. Conceivably one or more of these lost ships could have been wrecked on the North American coast (see William Lytle Schurz, The Manila Galleon, PP. 15, 251-283). 
${ }^{30}$ See p. 92, n. 54, of this study.

${ }^{31}$ See p. 91 of this study.

${ }^{32}$ see p. 27 of this study.

${ }^{33}$ See $P .40$ of this study; and Shelikhov, Travels, MS. trans. P. 18 .

${ }^{34}$ De Laguna, et al, Archaeology of the Yakutat Bay Area, Alaska, p. 26. The term "Canton ware" Toosely refers to a type of export Chinese porcelain of the late 18 th and early 19th centuries decorated with a so-called "willow pattern." As the name suggests, such porcelain wares are associated with Canton, and they were an important commodity in the maritime fur trade (see Duncan Macintosh, Chinese Blue and white Porcelain, pp. 120-121). It is not entirely clear from De Laguna's description what the porcelain ceramics at Yakutat were, except that they were thought to be "later than Canton ware" and similar to porcelain of the mid-19th century.

${ }^{35}$ See Thomas Newman, "Tillamook Prehistory and its Relation to the Northwest Coast Culture Area," p. 62. Similar Chinese porcelain fragments (dating from the 16 th to 18 th centuries) have also been reported from aboriginal sites at Nehalem Bay and Seaside, up the Oregon coast 30 and $65 \mathrm{~km}$. respectively from the Netarts site (see Herbert K. Beals and Harvey Steele, "Chinese Porcelains fram Site 35-TI-1, Netarts Sand Spit, Tillamook County, Oregon," University of Oregon Anthropological Papers, No. 23). A single Chinese porcelain sherd made into a pendant and dating from the 16th or 17th centuries was reported by Osborn at Umatilla, Oregon, $320 \mathrm{~km}$. upstream on the Columbia River (see Osborne, River Basin Survey Paper №. ㅇ, P. 105).

${ }^{36}$ Beals and Steele, "Chinese Porcelains from Site 35-TI-1," P. 1 .

${ }^{37}$ Chirikov's attempt to interest the natives at Adak in a Chinese cup is one of the few recorded instances that such articles figured in trade between Europeans and Alaskan or Northwest Coast natives. Also see Beals and Steele, p. 23.

${ }^{38}$ See Hubert Howe Bancroft, History of the Northwest Coast, I, 532-533; and Samuel Parker, Journal of an Exploring Tour Beyond the Rocky Mountains, P. 152 .

${ }^{39}$ See Antonio de Morga, Sucesos de las Islas Filipinas, PP. 226-227; and Schurz, The Manila Galleon, P. 259. 
${ }^{40}$ See Schurz, p. 260. Warren Cook, Flood Tide of Empire, $P .34$, using a French source, says the xavier sailed in January, 1707--a date that may be spurious because the Manila ships routinely departed the Philippines in June or July.

\section{${ }^{41}$ See Morga, Sucesos, P. 306. \\ ${ }^{42}$ Cook, Flood Tide of Empire, P. 34 , believed the} Xavier was the most likely possibility, ruling out the San Antonio on the grounds that "a quantity of goods found soon afterward on the northeast coast of Luzon suggests that it met its doom there." Nothing, however, is mentioned in either Morga (Sucesos) or Schurz (The Manila Galleon) about such wreckage from the San Antonio. In fact, her consort, the Nuestra Señora de los Remedios, managed to return to the Philippines and reported that both ships had been caught in a storm off Japan. That, according to Morga, was the last time the San Antonio was seen, and thus it is by no means unlikely that after the storm she was swept across the Pacific by the Kuroshio and North Pacific currents.

${ }^{43}$ See 0. F. Stafford, "The Wax of Nehalem Beach," Oregon Historical Quarterly, 9, No. 1 (1908), pp. 24-41. Morga, Sucesos, P. 309, says that in addition to the goods imported from China and elsewhere in Asia products of the Philippines also figured in the Manila trade, including "cakes of white and yellow wax."

${ }^{44}$ Cook, Flood Tide of Empire, P. 32.

${ }^{45}$ This information is based on personal communications (October, 1982) from John Woodward, Mt. Hood Community College archaeologist, who is currently engaged in a reexxamination of this material and its archaeological context. His work has tentatively established an association between the beeswax, Chinese porcelain sherds similar to those at Netarts, and iron fragments at an aboriginal site near Nehalem Bay.

46 Morga, Sucesos, $P .62$. Schurz, The Manila Galleon, P. 258, says the San Juanillo vanished in 1578. While Morga does not state the exact year she sailed on her last voyage, he does say that Sande was governor of the Philippines between 1575 and 1580. Cook, Flood Tide of Empire, p. 34, says another ship named San Juan disappeared in 1586, but of this there is no mention in either Morga or Schurz.

${ }^{47}$ Besides porcelains and other ceramics, Morga, Suce- 
sos, $P .306$, enumerates some of the other exotic Asian goods that came to Manila for export to New Spain: ivory; drapery of embroidered velvet; damasks, table cloths; cushions; carpets; caprisons for horses decorated with glass beads; pearls; rubies; sapphires; and crystals. And of less exotic order, besides beeswax, there were: metal basins; kettles and other vessels of copper and caste iron; nails of every sort; sheet iron; tin; lead; saltpetre; gunpowder; fine thtead; needles; beds; tables; chairs. There were so many things in fact that Morga dispaired of listing them all, writing that "to recount all of which would mean never finishing, nor would even masses of paper suffice for the task" (ibid., P. 306).

48 Ibid., P. 308.

${ }^{49}$ Schurz, The Manila Galleon, pp. 344-357.

${ }^{50}$ If the San Juanillo was indeed wrecked on the Oregon coast in 1578, that would have preceded Drake's voyage along the same coast by a year. Interestingly enough, there is some indication that Drake may have been responsible in part for Chinese porcelain fragments found archaeologically at Drakes Bay, California. Before anchoring on the California coast in June, 1579, Drake captured a Spanish merchantman whose cargo included Chinese porcelains, and it has been suggested that some or all of these wares may have been left at Drakes Bay. In 1595, the Manila ship San Aqustín was wrecked at Drakes Bay where its cargo, including beeswax and porcelains, was deposited on the beach. See Clarence Shangraw and Edward Van de Porten, The Drake and Cermeño Expeditions' Chinese Porcelains at Drakes Bay, California, 1579 and 1595 ; Robert Heizer, Archabological Evidence of Sebastian Rodriquez Cermeño's California Visit in 1595; and Wagner, Sir Francis Drake s Voyage Round the World, p. 271. 
CHAPTER $X$

\section{CONCLUSION}

Georg Steller's speculations about the source of the iron knives he saw among the natives at the Shumagin Islands can now be seen in better perspective. His thesis that trade between the Russians and Chukchis at Anadyrsk resulted in the spread of such articles into North America across Bering strait by means of aboriginal trade is probable enough, but this is only one of several sources that might have accounted for Steller's discovery. Even as early as 1741 , the avenues by which iron--or implements made of it--might have been procured by the Shumagin islanders were already more numerous than Steller could have imagined, and from that time forward each decade witnessed a growing complexity in the sources.

Both copper and iron were known to the native inhabitants of Arctic North America and northeastern Siberia well before historic times. What may be the earliest use of iron among Arctic natives has been reported archaeologically from a site at Point Hope on the Alaskan coast some 300 km. north of Bering Strait. The site, referred to as Ipiutic village, was dated by radiocarbon methods "probably to the first few centuries of the Christian era." ${ }^{9}$ The 
people of the so-called Dorset culture of northeastern North America, who also flourished in the first millenium A. D., are believed to have worked "solid copper and meteoric iron - . by hammering. ${ }^{2}$ They and their successors, the so-called Thule people, may have also come into possession of non-meteoric iron from medeaval Norse colonists before c. $1300 \mathrm{~A} \cdot \mathrm{D}^{3}$ The discovery of an "engraving tool with an iron point in a grave at the cemetery at Uelen on Cape Dezhnev (East Cape)" 4 has helped to confirm the prehistoric presence of iron on the shores opposite Alaska in northeastern Siberia. Drucker, as has already been noted, 5 says the so-called Punuk culture of St. Lawrence Island, between Siberia and Alaska, had iron by c. $1000 \mathrm{~A}$. D. These cases, to say nothing of the copper that Tlingit mythology associates so closely with the Copper River basin, all point to an early and pervasive knowledge of metals in the circumpolar regions of North America and northeastern Siberia. Although these are matters well beyond the scope of this inquiry, they help to show that there must have been a rudimentary acquaintance with metals among some Eskimo peoples centuries before the arrival of Europeans in Alaska.

It is much less certain, however, when a comparable prehistoric "metals age" began among the antecedents of the more southerly peoples known historically as the Aleuts, Chugach and Koniaga Eskimos, Iyaks, Tlingits, or other 
Indian tribal groups down the coast. Aside from small amounts of metal that may have filtered in from their aboriginal neighbors to the north, the most probable early source of metals for the people of the Aleutians, southern Alaska, and the Northwest Coast would have been shipwrecks or "drift iron." Although Drucker did not believe there were enough ships "with iron spikes and bolts" sailing the western Pacific "before Cook's day" (i.e., late 18th century) to consider this source significant, ${ }^{6}$ he seems to have forgotten that other and earlier seafaring traditions besides those of the Anglo-Americans had flourished in these waters.

A substantial maritime trade, for example, existed between Ming China and the Ryukyu Islands during the 14th, 15th, and 16th centuries in which the Chinese obtained horses and sulfur (the latter for gunpowder) in exchange for porcelain and iron. ${ }^{7}$ The ships engaged in this trade, many of which were Ryukyuan, sailed between Okinawa and the Chekiang coast, and in so doing they crossed a 150-km. -wide zone in the East China Sea known as the Black Current. This powerful oceanic stream flows northward along the west side of the Ryukyus toward the southern Japanese island of Kyushu, where it merges into the Kuroshio Current。 $^{8}$ The Ryukyu Islands are, moreover, notorious for typhoons in the summer and autumn. A ship disabled in one of these storms could have been carried by the Black Cur- 
rent into the Kuroshio and thence by the North Pacific Current to any number of locations on the Alaskan or Northwest coasts. Japanese ships operating off the east coast of the main islands of Japan or off the Kuril Islands and suffering disablement in a storm would likewise have been caught in currents ${ }^{9}$ carrying them into the Kuroshio and then eastward across the Pacific. In other words, the general concept of trans-pacific drift and specifically Rickard's "drift iron" thesis, as explanations of pre-European iron in northwestern North America, need not depend exclusively on the presence of European ships in the western Pacific. It is known that Chinese-Ryukyuan trade was first formalized in 1372 and that the Okinawan kings continued to be regarded as tributary vassals by the Kang $X i$ emperor in the early 18 th century. ${ }^{10}$ In the two-and-a-half centuries or more this trading activity continued some of the vessels plying between China and the Ryukyus must have been lost and it is possible that a few of them, or fragmentary wreckage proceeding from them, were carried to North America well before the 18 th century. ${ }^{11}$ Mention in historical sources of Japanese vessels carried across the Pacific reaches back to 1617, when a junk reportedly turned up off Acapulco after an involuntary drift voyage. ${ }^{12}$ Krasheninnikov, it will be recalled, also had been told by the Kamchadals that Japanese had traded with them for at least the previous 150 years, suggesting that by c. 1570 Japanese 
vessels were likely voyaging northward along the Kuril Islands. 13

Even European ships seemed to have figured as "drift iron" sources much earlier and to a greater extent than Drucker realized. The inauguration of the Manila-Acapulco trade in 1565 meant that during the late 16 th century and throughout the 17 th and 18 th centuries the Spanish galleons that annually sailed from Manila were all exposed to dangers that could have easily resulted in their being wrecked on the North American coast. In fact, they laid their courses directly towards that continent at latitudes sometimes as high as $44^{\circ} \mathrm{N}_{0}{ }^{14}$ At least three of these ships, as already discussed, are known to have vanished completely while attempting to cross the North Pacific, and the respective dates of their disappearances, 1578, 1604, and c. 1705, can be tentatively linked with finds of beeswax and porcelain sherds on the Oregon coast. 15

Another pre-18th century seafaring tradition overlooked by Drucker that may have resulted in wrecks or wreckage washing ashore in northwestern North America concerns the Russian advance to the Anadyr River in northeastern Siberia. While Steller was aware that this river, which empties into the Pacific some $600 \mathrm{~km}$. southeast of Bering Strait, was the scene of Russian-Chukchi trade, he probably know little about the details of the maritime activities connected with its inception. It was in fact 
the obscure sea venture led by Cossack Semen Dezhnev in 1648 that resulted in the establishment of the outpost at Anadyrsk where the Russians conducted the trade to which Steller referred. What happened in the course of Dezhnev's little-publicized voyage has more than incidental importance for this inquiry. ${ }^{16}$

The flotilla that sot out from the mouth of the Kolyma River on the Siberian Arctic coast in the summer of 1648 to find a rumored river to the east comprised seven ships. 17 Of these, three managed to reach Bering Strait where one of them was wrecked near Cape Dezhnev. The remaining two ships, one commanded by Dezhnev and the other by Fedot Alekseyev, the expedition's principal organizer, succeeded in doubling the cape, with Dezhnev's koch (as the type of vessel in which they sailed was called) reaching a point somewhere south of Anadyr Bay; Alekseyev's ship eventually was wrecked much farther south, possibly on the Kamchatkan east coast. ${ }^{18}$ Dezhnev and some of his men are known to have reached the Anadyr River, setting up an outpost there the following spring. The fate of the four missing kochi, however, is something of a mystery. Although it is generally presumed they were lost at sea, probably in the Arctic Ocean, rumors circulated in northeastern Siberia in the 18th century that a "lost Russian colony" existed somewhere in Alaska vaguely linked to the missing ships of 1648. 19 Soviet historian Svetlana G. Fedorova, writing in 
1973, believed there could be some truth underlying these stories, and that one or more of Dezhnev's four missing kochi may well have been "carried away to the coast of Alaska." 20

While the idea of a "lost Russian colony" surviving for decades in the isolation of some Alaskan cove seems only a remote possibility, ${ }^{21}$ it is by no means unlikely, as fedorova has suggested, that one or more of the vessels that disappeared during the 1648 expedition could have been urecked in Alaska, or wreckage from them washed ashore there. Even if this did not happen, we know fairly conclusively that one of the vessels that made it to Bering Strait was wrecked near Cape Dezhnev (on the Asiatic side). The Chukchis or Asiatic Eskimos thus would have had, at the least, access to the iron nails, spikes, and bolts of that ship. If the wreckage remained intact, iron implements commonly carried aboard such ships 22 as well as trade goods would have also fallen into native hands. We can judge something about what might have been included among these trade goods from surviving customs records. A travel document (or passport) carried by Alekseyev dating from July, 1642, issued by the Yakutsk customs office, lists among his possessions " 20 pounds of small and large blue beads." 23 A similar customs house declaration at Yakutsk made by the two merchant's agents in whose boat Dezhnev made the 1648 voyage, dated June, 1646, also mentions 
"5,000 blue beads," as well as "400 copper buttons," "15 metal bars," and "28 small bells with tassels," all of which must have been intended for trade. 24

It thus seems safe to conclude that trading activity based at Anadyrsk (1649-1764), 25 possibly supplemented by an occasional Russian shipwreck, was the probable source not only of the iron in the knives steller saw but of the iron and blue beads that Cook reported among Alaskan natives who otherwise showed no evidence of European contact. While Chukchi middlemen no doubt were principal figures in this chain of supply, direct contact between Russians and Alaskan natives prior to 1741 could have occurred as a result of shipwrecks involving intact vessels with survivors. That at least one such event may have happened as far east as Yakutat Bay is suggested by the story De Laguna obtained from native informants there. 26 The existence of a so-called protohistoric period among the Chugach Eskimos at Prince William Sound, as posited by De Laguna and of which she considered iron and blue beads ("Cook-type") archaeologically diagnostic, seems a near certainty. Insofar as Russian supply sources are concerned, the earliest date for such a period can be fixed with some confidence at c. 1648. An occasional errant Japanese or Chinese vessel (or drift wreckage therefrom) may have reached Alaskan waters and conceivably could push that time back, but no conclusive evidence of such an earlier date has yet been 
adduced. 27 Farther south on the Oregon coast, however, evidence is emerging ${ }^{28}$ that supports the thesis of a similar protohistoric period in that area which may prove to date as early as the 1570 .

Turning to the period in which historical evidence becomes the primary source of information (i.e., since 1741), the sequence of events in which Alaskan and Northwest Coast natives were introduced to foreign materials is more certain. In Alaska, particularly in the Aleutian Islands, no more than two years elapsed between the first appearance of government-sponsored exploring vessels (in 1741 ) and a long succession of Russian trading ventures bent on exploiting these newly discovered lands. The fur gathering methods employed by promyshlenniki, however, relied more on iasak or tribute payment than on large-scale exchanges of goods. Except for instances such as the Aleut rebellion of 1763,29 Alaskan natives had access to only small quantities of Russian articles, and thus, as Cook observed while at Unalaska, the natives who lived in close association with Russian fur hunters had fewer matallic articles than those who did not. Instead of the welter of manufactured goods later distributed by Anglo-American traders, the Russians left a trail of blue glass beads, small metallic articles such as buttons, bells, or pipes, small amounts of iron, and paper iasak receipts. By the time the Spanish made their first reconnais- 
sance of the Northwest Coast in 1774 Russian promyshlenniki had been operating for three decades in the Aleutians and as far east as Kodiak Island. Neither the Pérez expedition of 1774 nor its two immediate successors in 1775 and 1779, however, saw enough material evidence of European contact to cause them to report to their superiors that the Russians had penetrated the coast eastward and southward of the Kenai Peninsula. Documentary evidence from Russian sources shows they were probably correct in this judgement. Strangely enough, however, the pieces of a bayonet and sword Pérez saw among the Haida in the Queen Charlotte Islands in 1774 seems not to have aroused much speculation that these objects might have come from Russian sources. 30 Articles of beaten copper Pérez saw among the Nootka led him to believe there must have been "some mines of this metal" 31 thereabouts, but he wasted little speculation on explanations involving other European visitors.

When the English came to the coast in 1778, Cook saw ample evidence of $i r o n$ and copper among the natives at Nootka Sound, and he began to realize that native trade must have played a significant role in supplying such materials. Nevertheless, he refused to concede that the Russians might be the sole or even principal source of these materials, preferring instead to attribute equal importance to Anglo-American sources in the North American interior or the Spanish to the south. As Cook's ships 
advanced northward and westward to the Aleutians, the Russian presence became evermore apparent until finally they met Izmailov face to face at Unalaska. But even with this, Cook showed little inclination to believe the Russians had been east of Unimak Island at the west end of the Alaska Peninsula.

There is in the records of 18th century Spanish and English voyages of discovery on the Alaskan and Northwest coasts an underlying thread of national rivalry, distrust, and mutual concern over the extent of Russian penetration there. The earnest desire of these navigators, whether Spanish or English, to establish priority claims for their respective sovereigns could not but help color their interpretations of evidence concerning the possibility or extent of previous European contact.

By the time French explorer Jean de La Pérouse arrived on the coast in 1786, he was less encumbered by such motives since the question of priority was by then largely moot. The best the french could hope for was to explore those sections of the coast that were believed to have escaped the attention of Russian, Spanish, or English navigators. In doing this, and with less reason to prejudice Russian accomplishments, La Pérouse was in a better position to reach objective conclusions about the probable sources of foreign articles and their means of distribution among the Alaskan and Northwest Coast natives. His obser- 
vations convinced him that Lituya Bay was a waystation in an extensive coastal trading system that brought iron, copper, small brass articles, and glass beads from points northward in exchange for furs (which moved in the opposite direction), and that it must have ultimately--though not necessarily directly--involved the Russians. 32

About the same time La Pérouse was making these observations and shaping his cogent thesis, ships flying the Union Jack were just beginning to mount a series of commercial ventures that would eventually upset this pattern by introducing large quantities of exogenous goods into the native trading system from an altogether different quarter. The first English commercial fur traders, who were following the pathfinding lead of James Cook, naturally headed for Nootka and Prince William sounds because these were harbors about which they had the most knowledge. But they soon found the competition of Russian fur hunters in the North, to say nothing of the uncongenial Alaskan winters, sufficient reason to prefer Nootka as a base of operations. While this eventually led to political troubles with Spain, 33 which steadfastly maintained prior and exclusive claims based on the discoveries of the pérez and HezetaBodega expeditions, the temperate winters and absence of Russian promyshlenniki at Nootka were perceived to outweigh any problems with the Spanish--who were, after all, not engaged in the fur trade commercially. 
English fur trading methods differed significantly from those of the Russians. Exacting tribute payments in the name of their sovereign was not a concept prevailing among the English traders, and had they resorted to such methods it is doubtful if they would have had much success anyway. Most of the native peoples with whom they dealt-from the Tlingits southward--had well-developed trading instincts that militated for an exchange of material goods in which hard bargaining played a significant role. Trade among the Aleut and Eskimo peoples, with whom the Russians had primarily dealt, was less intense and not so concerned with bargaining. When Russian activity eventually spread to Sitka, in the heart of Tlingit territory, imposition of the tribute system met with little success-open hostility in fact--among people who insisted on more than token gifts or paper receipts. 34 The English, on the other hand, were singularly well suited to trade with the hardbargaining Northwest Coast Indians because they came from a mercantile society with abundant and varied supplies of fabricated articles. 35 English traders were nominally restricted by licensing requirments of the East India and South Sea companies, but these limitations were mostly ignored or circumvented by traders such as John Meares.

The American vessels that first appeared on the Northwest Coast in 1788 employed trading methods differing little from those of the English. While American fur 
traders were unencumbered by government or company monopolies, they seem not to have enjoyed the advantage of large and varied supplies of trade goods, which forced them to seek out more remote or unfrequented locations where the natives asked lower prices. Another tactic they adopted was to fabricate trade articles of their own design, such as Ingraham's collars or Roberts' swords, which capitalized, temporarily at least, on the natives' fascination with the unusual. Besides his famous collars, Ingraham initiated traffic in firearms in 1791 (although he may have been preceded in this by some of the unlicensed English traders). Of this practice, Baranov, Marchand, and Vancouver all agreed in their condemnation of it. 36

French fur traders were not numerous enough to constitute a significant source of foreign articles. Like the English and Americans, they had neither the inclination nor means to impose tribute payments, so they purchased their furs as best they could with articles that were currently most in demand and vogue. At Sitka, in 1791, Marchand was astonished to find nearly all of the natives attired in English-made clothing and completely disinterested in the usual small trade items such as beads, rings, or buttons. To the French, these Sitka Tlingits seemed almost Europeanized, a fact made more remarkable because the identity of the fur traders supplying the wherewithal for this transformation remains uncertain. In any event, 
the french found themselves rummaging through their ship, as did many another American fur trader, for used clothing or anything else that would satisfy the natives' demands in order to purchase the sea otter pelts for which they believed the Chinese would pay so dearly. 37

As the last decade of the 18 th century came to a close, the traffic of commodities between Asia and North America unquestionably assumed proportions never previously known. Yet, as much of this inquiry has tried to show, trans-Pacific trade connections, together with those along the North American and Siberian littorals and island chains existed long before the maritime fur trade reached its height. Nearly every European voyager on the coasts of northwestern America in the 18 th century observed some degree of evidence that the native peoples there were familiar with or possessed metals and other exogenous materials. This astonished, puzzled, and disconcerted them. It seemed inconceivable, particularly to the earliest Spanish and English explorers seeking to establish prior claims of sovereignty, that other Europeans had somehow preceded them; they were even more skeptical that Asian navigators might have previously reached these coasts. 38

Steller first theorized, Cook suspected, and La Pérouse confirmed by observation, that native trade was in fact a powerful factor underlying this phenomenon. The 
blue beads Cook described at Prince William Sound, which appear to have first entered the native trading system at Anadyrsk in northeastern Siberia in the mid-17th century, occasionally show up archaeologically in Oregon sites as much as $5,000 \mathrm{~km}$. away. 39 The ability of this native trade system to move articles over considerable distances is especially evident in the journals of fur traders who operated on the coast after c. 1788, when the abundance of trade goods began to glut the native markets.

Bruno de Hezeta appears to have recorded the first hint that "drift iron" was another piece in the puzzle. Neither he nor other explorers or fur traders in the 18 th century seemed to have fully sensed the importance of this source--indeed, anthropologist Philip Drucker in the 20 th century was skeptical. But this inquiry, in marshalling evidence of the considerable variety of ships--Chinese, Japanese, Ryukyuan, Russian, Spanish, Portuguese, Dutch-sailing the northwestern Pacific from at least as early as the 14 th century, strengthens the credibility of Rickard's "drift iron" thesis.

The picture that seems to emerge down to historic times may thus be summarized: southern Alaskan coastal natives probably became acquainted sometime in the early second millenium $A$. D. with small quantities of copper and possibly meteoric iron originating from somewhere in the Arctic interior of North America or northeastern 
Siberia. From this, a prehistoric acquaintance with coldhammering metal working techniques must have emerged and spread southward to some as yet unknown point on the coast. As early as the 16th century, supplies of iron, copper, or brass started to become available as a result of occasional accidental shipwrecks, drift voyages, or wreckage (involving the several sources that have already been discussed in this work). In the mid-17th century, small quantities of iron, blue glass beads ("Cook-type"), and small copper or copper-alloy objects such as bells or buttons, began entering the native trading system at Anadyrsk on the Chukotskii Peninsula of northeastern Siberia. These materials gradually spread through intertribal trade to the west coast of Alaska, into the Aleutian Islands, eastward to Prince William Sound, Yakutat, and finally southward down the coast possibly as far as the Columbia River. This "protohistoric" period ended in the Aleutian Islands in 1741 and on Kodiak Island by 1764 with direct Russian contact. The Spanish expeditions of 1774 and 1775 accomplished the same thing in the Queen Charlotte Islands, at Nootka, and on the Washington coast. By 1778, when Cook arrived at Nootka, wondering at the abundance of iron and copper there, the "historic" period had already begun. 
Tordon R. Wiley, An Introduction to American Archaeology, I, 438 .

2 Bandi, Eskimo Prehistory, p. 142.

3 Ibid., PP. 142, 169.

${ }^{4}$ Ibid., P. 76.

${ }^{5}$ See p. 180 of this study.

6 Ibid.

${ }^{7}$ See Richard J. Pearson, Archaeology of the Ryukyu Islands, PP. 115-117.

8 Ibid., P. 19.

${ }^{9}$ The Oyashio Current sweeps southward along the west coast of Kamchatka and the Kuril Islands, merging with the Kuroshio off the northwest coast of Honshu. The eastward flow of these merged currents is called the Kuroshio Extension or North Pacific Current.

10 In 1372, a Chinese envoy, Yang Tai, formally opened trade relations with Okinawan kings, bringing them within the Ming tributary system. The ships for this trade were initially supplied by the Chinese, although after the mid-15th century they apparently were built in Okinawa following Chinese designs. Recent studies of Chinese vessels of the 14th and 15th centuries suggest that they were much advanced over European ships of that time, and that they were fully capable of long-distance ocean voyaging (see Pearson, Pp. 115-117; and Donald H. Keith and Christian J. Buys, "New Light on Medieval Chinese Seagoing Ship Construction," The International Journal of Nautical Archaeology and Underwater Exploration, 10, No. 2 (1981), $\mathrm{pP}$. 119-132). Relations between the Kang $X_{i}$ emperor and okinawa are described in an account attributed to the Chinese envoy of 1719, Su-poa-Koang (see John M'Leod, The Voyage of the Alceste to the Ryukyus and Southeast Asia, pp. 6987).

${ }^{11}$ Finds of pre-Qing Chinese coins and porcelain in British Columbia and Oregon (see pp. 185, n. 15, 192-193, of this study) could be evidence--albeit tentative--supporting this contention.

${ }^{12}$ This incident is mentioned in Brooks, "Report of 
Japanese Vessels," p. 9; and in Bancroft, History of the Northwest Coast, II, 532, n. 14 .

${ }^{13}$ see p. 183 of this study.

${ }^{14}$ Schurz, The Manila Galleon, p. 227, says: "The height at which the galleon made her crossing varied from about thirty-one to forty-four degrees, but the majority varied between the thirty-second and thirty-seventh parallels. - . Many of the earlier galleons sailed above forty, where the winds were believed to be more dependable." Antonio de Morga, Sucesos, $P .322$, says in his time (c. 1600) the galleons crossed "as high as a latitude of forty-two degrees north."

${ }^{15}$ See pp. 194-196 of this study.

${ }^{16}$ There are no journals, logs, or participant accounts of this voyage, and in part for this reason American historian Frank $A$. Golder (see his Russian Expansion in the Pacific, 1641-1850, PP. 67-95) was skeptical of its authenticity. His doubts, however, have been convincingly laid to rest by Soviet scholarship and the work of Raymond $H$. Fisher. For details of this controversy see Fisher, "Semen Dezhnev and Professor Golder," Pacific Historical Review, 25, No. 3 (1956), pp. 281-292; and for a compilation of sources and early secondary accounts supporting the voyage's authenticity (in English trans.) see Fisher, The Voyage of Semen Dezhnev in 1648.

${ }^{17}$ They were single-masted vessels called kochi, which apparently were well suited to Arctic navigation. They were keeled, employing a skeleton of ribs braced with cross beams, and covered with double-layered planking. "Fastening was made," says Fisher, "with wooden trenails as well as iron nails, spikes, and bolts" (Voyage, p. 164).

18 word of Alekseyev's fate was later learned from a native Yakut woman who had been the former's concubine. She was captured (c. 1653) by Dezhnev from the Koryaks who inhabited the territory south of the Anadyr River as far as Uka in northern Kamchatka. Dezhnev says she told him "that Alekseyev and service-man Gerasim [Ankudinov] died from scurvy and some companions were killed. A few remained who fled in boats (lodki) with only their souls, I do not know where." Georg Fredrick Müller, the first chronicler of Dezhnev's voyage, believed some of Alekseyev's men, including his son, probably reached Kamchatka and lived among the Kamchadals there (see Fisher, Voyage, PP. 37-38, 54). 
${ }^{19}$ According to Peter Simon Pallas, for example, the journal of a Cossack named Ivan Kobelev mentions that in 1779 during an expedition among the Chukchi of the Chukotskif Peninsula he was told by the Anadyr Russians . that such a colony of Russians really exists on the mainland of America." The Chukchi themselves allegedly knew of this colony, for they had been told by the Bering strait islanders (Eskimos) of bearded people living to the eastward who purchased iron from them and made "the sign of the cross, and set up little boards . . with written characters, before which they hold common prayer." Pallas, however, was suspicious of Kobelev's credulity, remarking that "all this might very woll be Chukchi fables" (see Masterson and Brower, Bering's Sucessors, pp. 94-95).

${ }^{20}$ Svetlana G. Fedorova, The Russian Population in Alaska and California: Late 18 th Century-1867, P. 48. Fedorova also believed that there were very likely other even more obscure voyages of Russian fur hunting vessels in the mid-1640s along the Siberian Arctic littoral which could have resulted in wrecks or wreckage on the Alaskan coast.

${ }^{21}$ See Ibid., pp. 90-99, for discussion of a supposedly 300-year-old Russian settlement reportedly found on the Kenai Peninsula in 1937. Whatever this find may have been, it was not investigated under archaeologically controlled circumstances and so its value as evidence was lost.

22 Fisher, Voyage, P. 187, says: "The officials at Yakutsk furnished each detachment of service-men with a set of tools, which made it possible to construct boats in the course of a journey. The tools included augers, chisels, adzes, gimlets, draw knives, saws, and axes." Dezhnev's kochi, according to fisher (ibid., p. 187), were not equiped at government expense, so we cannot be certain every one carried such tools--only that those travelling in kochi carried them.

\section{Ibid., pp: 89-91. Document 22: "6 July 1642.} Travel document carried by Fedot Alekseyev en route to the Olenek River via the Lena River, issued by the Yakutsk customs office."

24 Ibid., pp. 97-99. Document 25: "27 June 1646. Declaration of goods of Afanasiy Andreyev and Bezson Astaf'yev, agents of merchant Afanasiy Fedotov Gusel'nikov, at the Yakutsk customs house, on their departure from the Indigirka, Kolyma, and other rivers." 
${ }^{25}$ The outpost Dezhnev established at Anadyrsk in the spring of 1649 was on an island in the Anadyr River some $275 \mathrm{~km}$. upstream from its mouth. It consisted of a fort constructed of poplars, with five towers, one gate, a church, and 130 houses at the time it was abandoned in 1764 as unprofitable (see James R. Gibson, Feeding the Russian Fur Trade, Pp. 15-16). Thus materials emanating from this source had well over a century to be traded through aboriginal channels from the Chukotskii Peninsula into Alaska and beyond.

${ }^{26}$ See pp. 167-168 of this study.

27 It will be recalled that dates reliably attributed to Chinese coins found in Alaska are no older than 1644 (see PP. 188-189 of this study).

28 See PP. 192-197 of this study.

${ }^{29}$ See Pp. $32-34$ of this study.

${ }^{30}$ The connection of these articles with Chirikov's missing men seems an obvious though speculative possibility. Mary Gormly, "Early Culture Contact on the Northwest Coast, 1774-1795," Northwest Anthropological Research Notes, 11, No. 1 (1977), P. 7, contended that Pérez assumed this was the source of these objects, but there is no mention of this in his "Diario" nor in those of the Franciscan fathers, Peña and Crespi.

${ }^{31}$ Pérez, "Diario," "Note" following the entry for August 7 and 8, 1774 .

${ }^{32}$ The Eyak Indians at the mouth of the Copper River appear to have been the principal middlemen between Tilingit traders and aboriginal peoples living north and westward of the Copper River. Materials these latter peoples obtained from Russian sources could have moved into Tlingit trading channels through the medium of Eyak middlemen without direct Russian-Tlingit contact.

${ }^{33}$ These troubles culminated in the Nootka Controversy of 1792 (see Cook, Flood Tide of Empire, Pp. 327-433).

${ }^{34}$ Georg Langsdorff, writing of his visit to Sitka in 1805, described the poor state of trade relations between the Russians and the Kolosh, as they called the Tlingits: "The visits of the Koluschians . - are almost always undertaken for purposes of traffick: they commonly bring with them sea-otter skins, which are presented to the commandant, and they desire to have in return presents to 
the same value, of such things as they want. If they are not contented with what is offered then they take the skins already presented back again . - the Russians cannot properly be said to carry on any trade with the Koluschians. - since the few skins that are procured in this kind of barter are not worth mentioning when the question is of trade in the gross" (see Georg Langsdorff, Voyages and Travels in Various Parts of the World, II, 113).

${ }^{35}$ The maritime fur trade, initiated in 1785 , came on the heels of the widespread shift from domestic industries to the factory system (i.e., the Industrial Revolution) that began in England during the mid-18th century. By the beginning of the 1780s, the English copper and brass industries had achieved a notable ascendency in overseas as well as home markets. Birmingham, an important center of these industries, supplied markets throughout Europe, Africa, and America, and doubtless many of the articles traded on the Northwest Coast originated in that city (see Henry Hamilton. The Enqlish Brass and Copper Industries to 1800, p. 292).

\section{${ }^{36}$ See Khlebnikov, Baranov, P. 29; Marchand, Voyage,} pp. 421-422; and Vancouver, Voyage, P. 229.

37 Marchand's cargo of furs, ironically, never reached the Chinese, for when the Solide put in at Macao the same decree that prevented Ingraham from selling his furs (see p. 143, n. 52, of this study) was in effect. The furs were instead carried aboard the Solide to france where they reached Lyon. There, during a seige of that city by counter-revolutionaries, the furs were impounded, and by the time their owner, Baux's, obtained their release they were worm-eaten and nearly worthless (see Marchand, Voyage, II, 552; and Dunsmore, French Explorers, I, 352).

38 As Juan Pérez was a former pilot on the ManilaAcapulco run it seems he might have given some thought to the possibility that one of the naos de China had been wrecked on the Northwest Coast. But there is no such indication in his "Diario." Fray Juan Crespi, one of the chaplains on the 1774 expedition, did remark on the physical resemblance of Northwest Coast natives to the Chinese: "The Captain [Pérez], who spent a great deal of time in China and the Philippines, says that they greatly resemble those that come from China" (see Cutter, The California coast, P. 239).

39 A particularly interesting example of this is reported by John Woodward, Mt. Hood Community College archaeologist (personal communication). A single well-worn 
"Cook-type" blue glass bead was found in a Clackamas grave (in northwestern Oregon, some $160 \mathrm{~km}$. inland) in association with an abalone-shell pendqnt (possibly made from shells traded in 1774 at Nootka Sound $600 \mathrm{~km}$. away by the Pérez expedition), dentalia (also from Vancouver Island), bracelets made from iron spikes, and copper pendents and rolled beads, all traded inland from somewhere on the coast. 
CHRONOLOGY OF VOYAGES TO THE ALASKAN AND NORTHUEST COASTS, 1648-1799

The following chronology lists the vessels, their commanders, sponsors or ouners, nationality, and principal places visited, that sailed in Alaskan or Northwest coast waters from the mid-17th century to the end of the 18 th century. The vessels included are based mainly on similar chronologies compiled by Raisa Makarova for Russian fur trading voyages, and by $F$. W. Howay for English, French, and American fur trading vessels. Their respective chronologies, however, do not include government-sponsored exploring voyages, which have been added to this chronology. In some instances, fur trading voyages based on sources other than Makarova or Howay have been included. The references upon which each entry in this chronology is based are abbreviated as follows:

Ba - Bodega y Quadra, "First voyage •. . 1775."

Ba2 - Bodega y Quadra, "Second Expedition . • 1779."

Be - Beaglehole, The Journals of Captain James Cook.

Bh - Berkh, A Chronological History of the Discovery of the Aleutian Islands.

Bt - Bancroft, History of the Northwest Coast.

Ce - Coxe, Russian Discoveries between Asia and America.

Ck - Cook, Flood Tide of Empire. 
Cr - Cutter, Journal of Tomás de Suría.

Ct - Colnett, "Journal of the 'Prince of Wales."

D - Dixon, A Voyage Round the World.

F - Fisher, The Voyage of Semen Dezhnev in 1648.

$G$ - Golder, Bering's Voyages.

Ha - Hezeta, "Diario •. 1775."

Hs - Hayes, Log of the Union.

Hy - Howay, "A List of Trading Vessels in the Marltime

Hy2 - Howay, Voyages of the "Columbia" to the Northwest Coast.

Hy3 - Howay, The Journals of Captain James Colnett . 1789 to 1791 .

Hy4 - Howay, "A Yankee Trader on the Northwest Coast, 1791-

I - Ingraham, Voyage to the Northwest Coast of North America.

K - Khlebnikov, Baranov.

L - La Pérouse, A Voyage Round the World.

Ma - Makarova, Russians on the Pacific, 1743-1799.

Me - Meares, Voyages.

Mn - Masterson and Brower, Bering's Successors, 1745-1799.

Pk - Portlock, A Voyage Round the World.

Pz - Pérez, "Diario •. 1774."

$R$ - Roe, The Journal and Letters of Captain Charles Bishop.

Se - Strange, Journal and Narrative of the Commercial Expedition $\cdot$ - to the Northwest Coast of America.

Sv - Sarychev, Account of a Voyage of Discovery. 
Ts - Turanzas, Relación del viage hecho por . - Sútil y Mexicana en . $\cdot 1792$.

Tv - Tikhmenev, A History of the Russian-American Company.

$V$ - Vancouver, A Voyage of Discovery.

$w$ - Wagner, Cartography of the Northwest Coast of America.

W2 - Wagner, Spanish Explorations in the Strait of Juan de Fuca.

W3 - Wagner, "The Journal of Don Jacinto Caamaño."

W4 - Wagner, "The Last Spanish Exploration of the NorthCoast." 


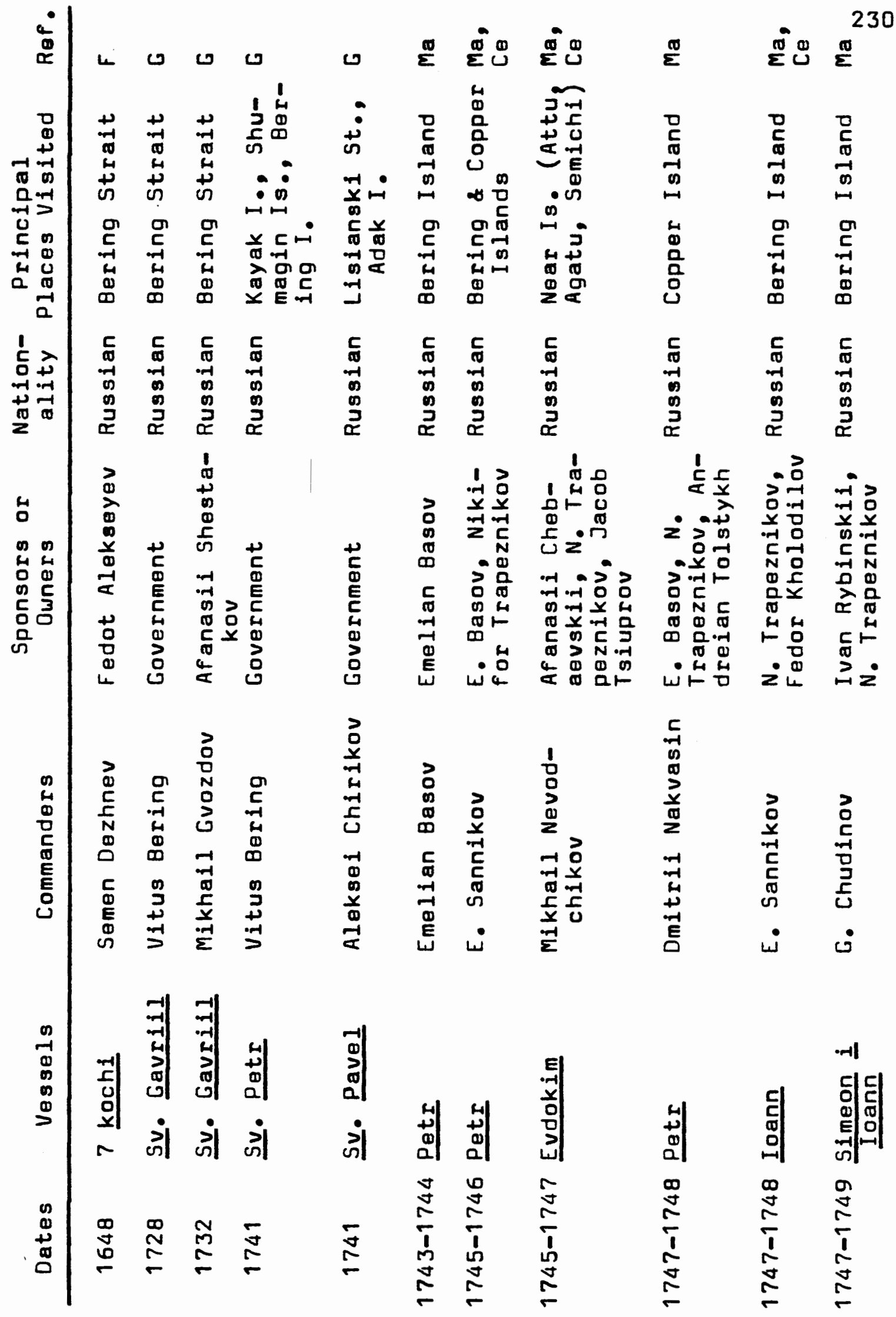




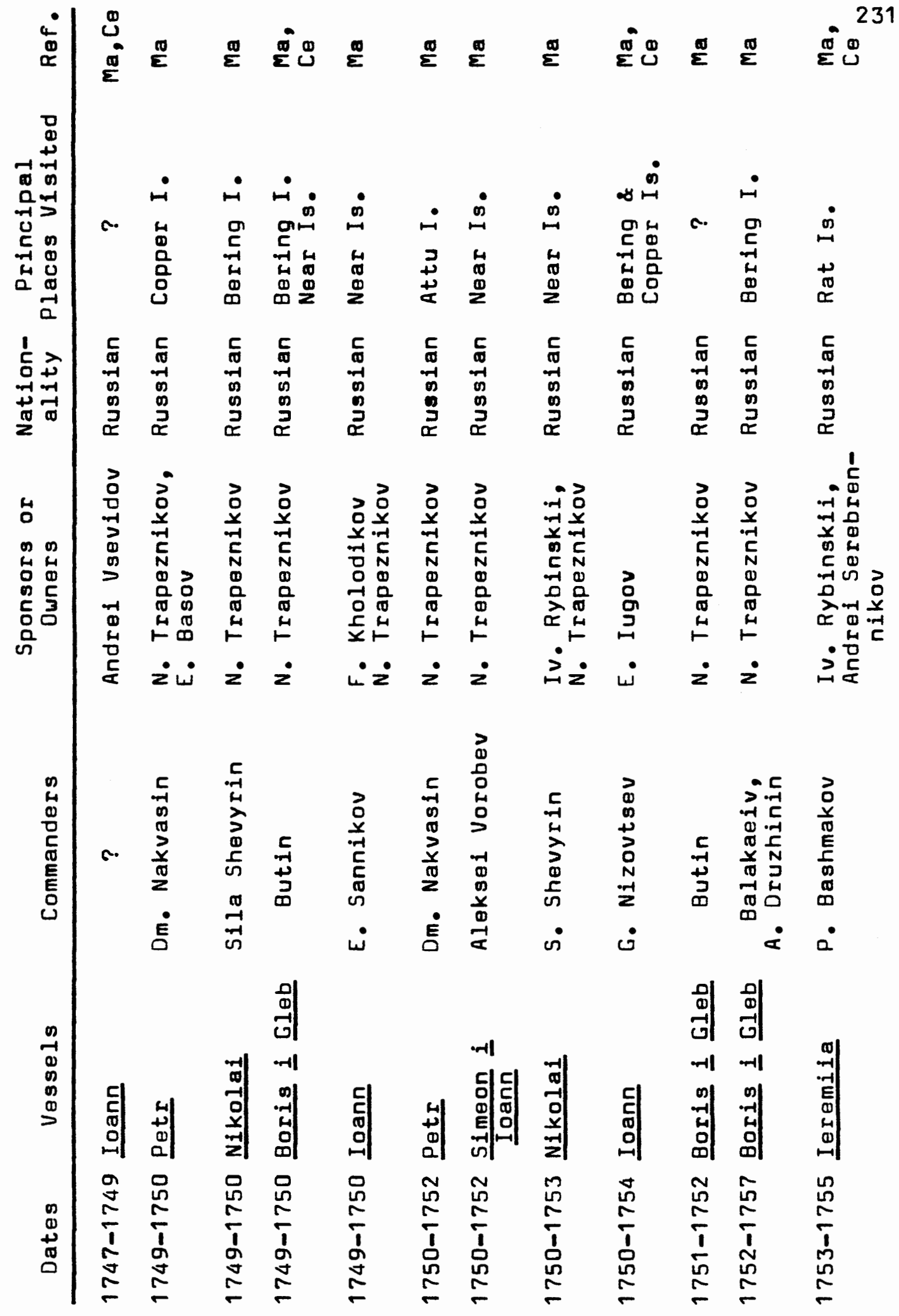




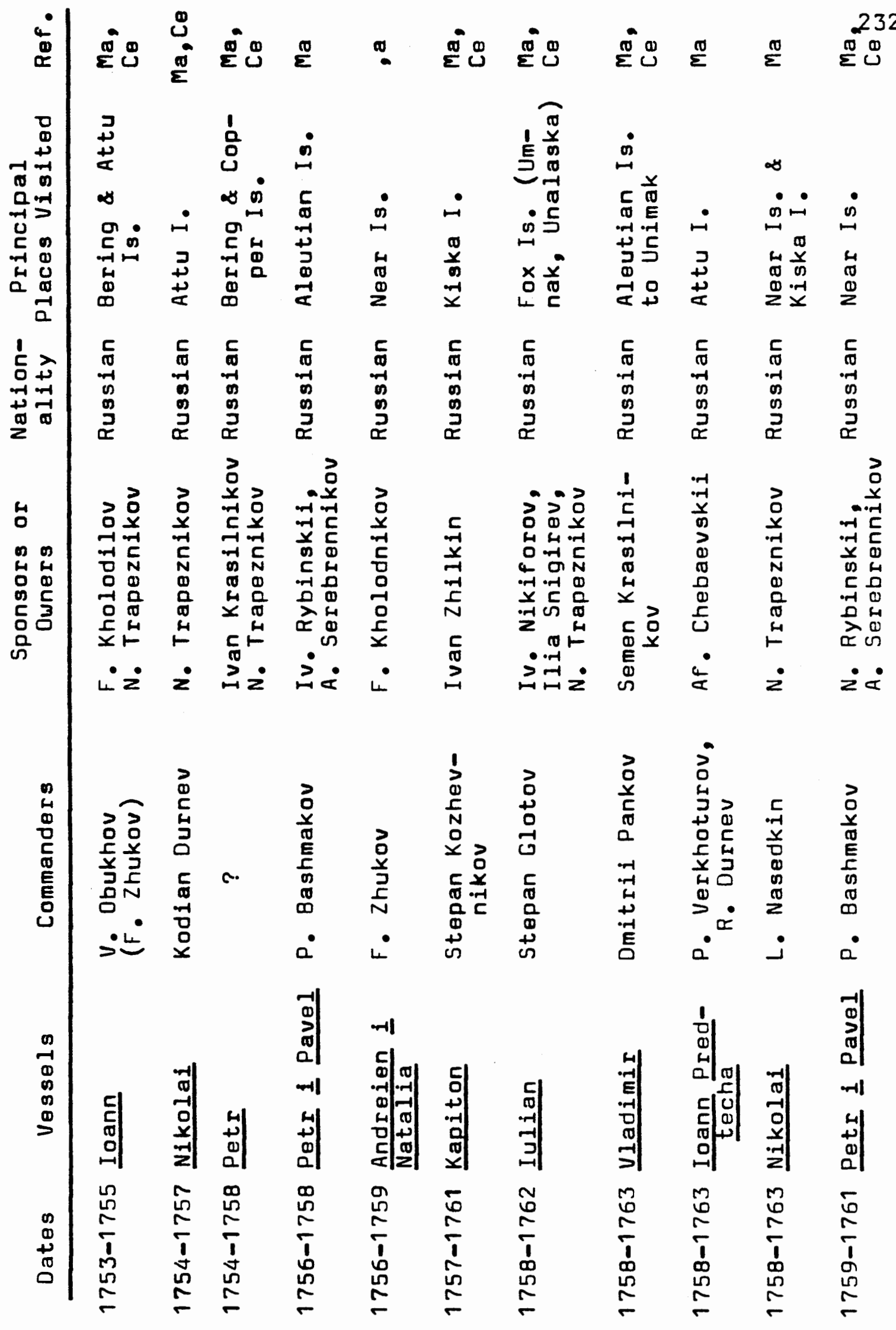




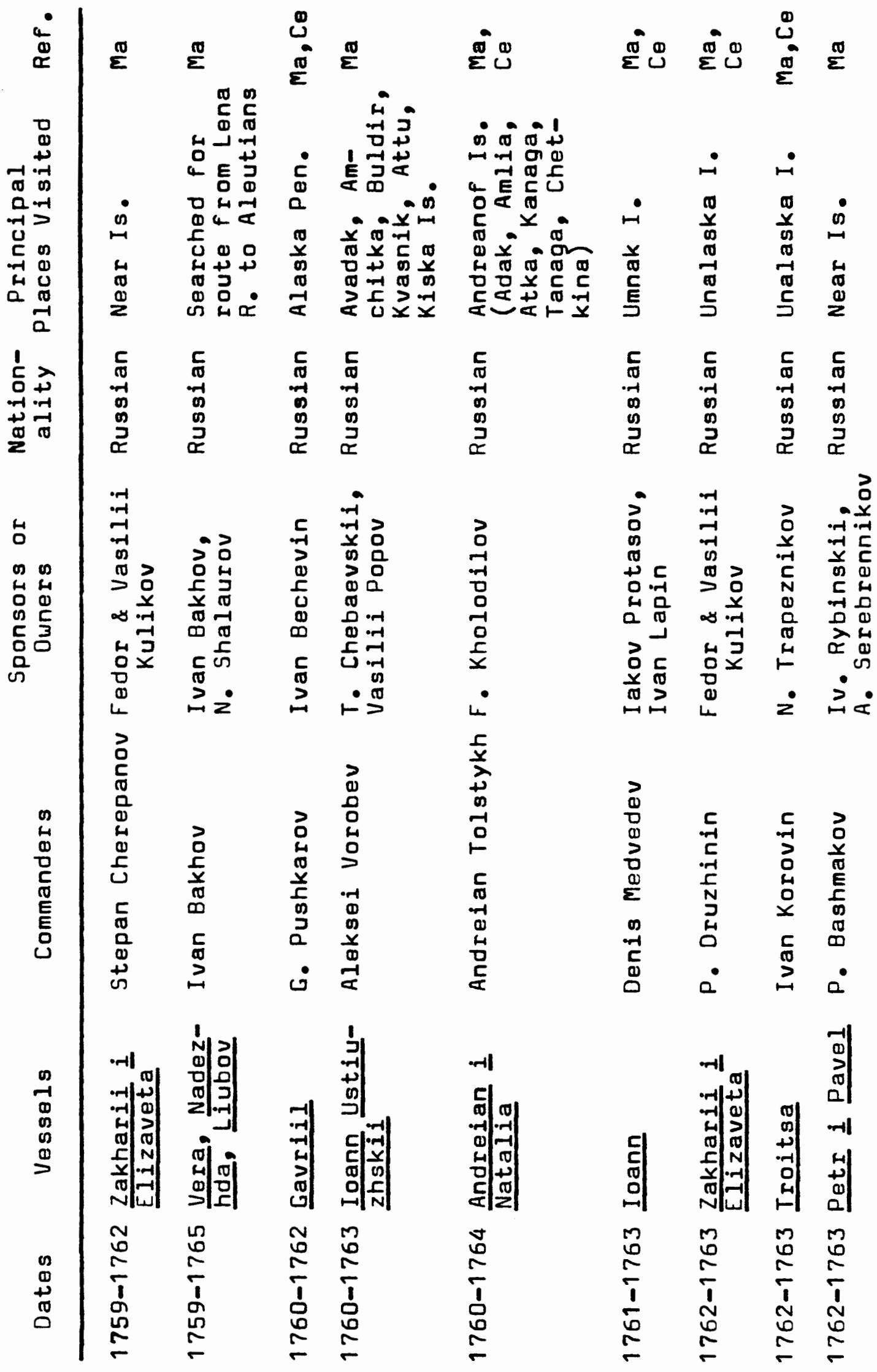




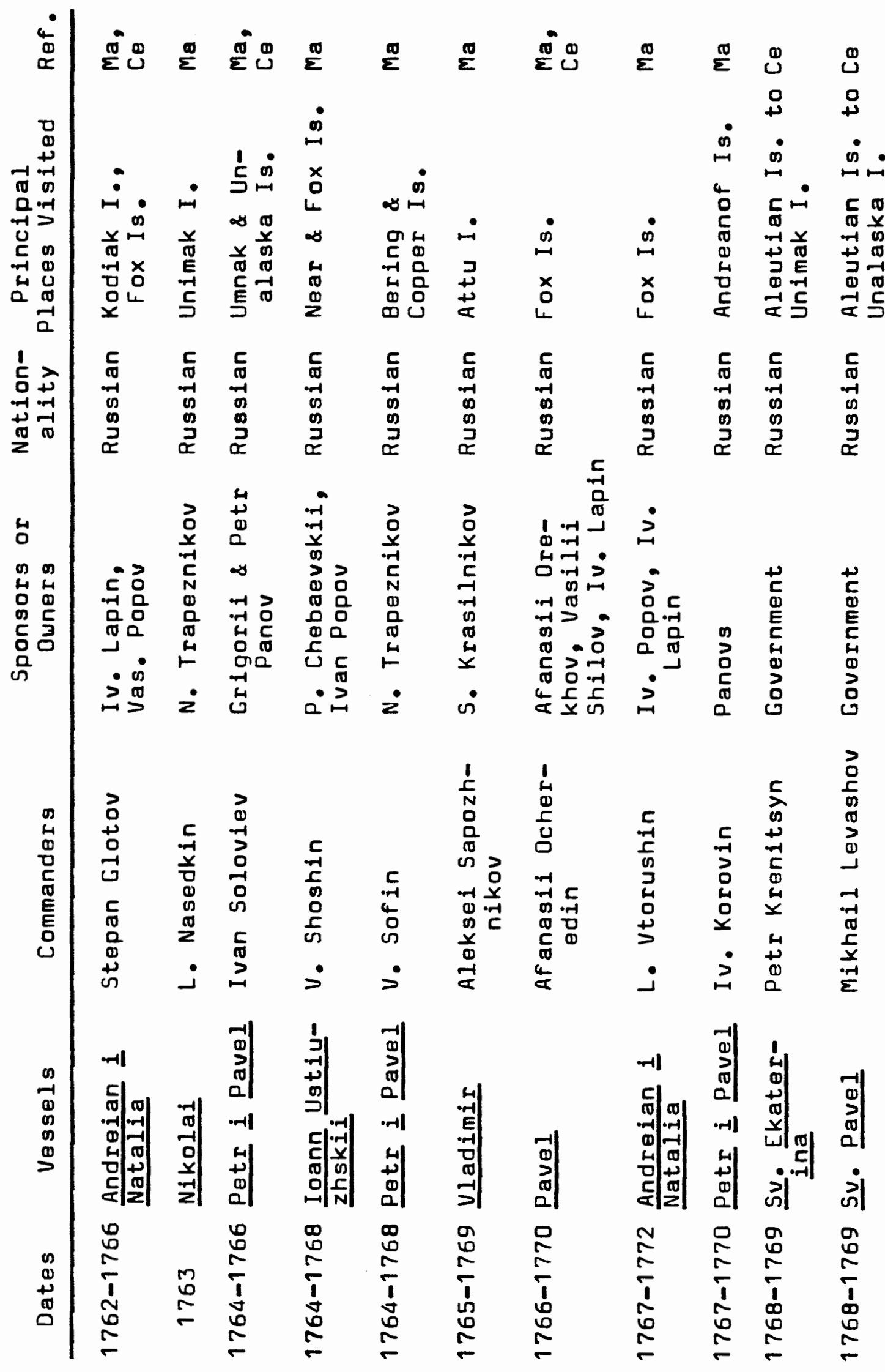




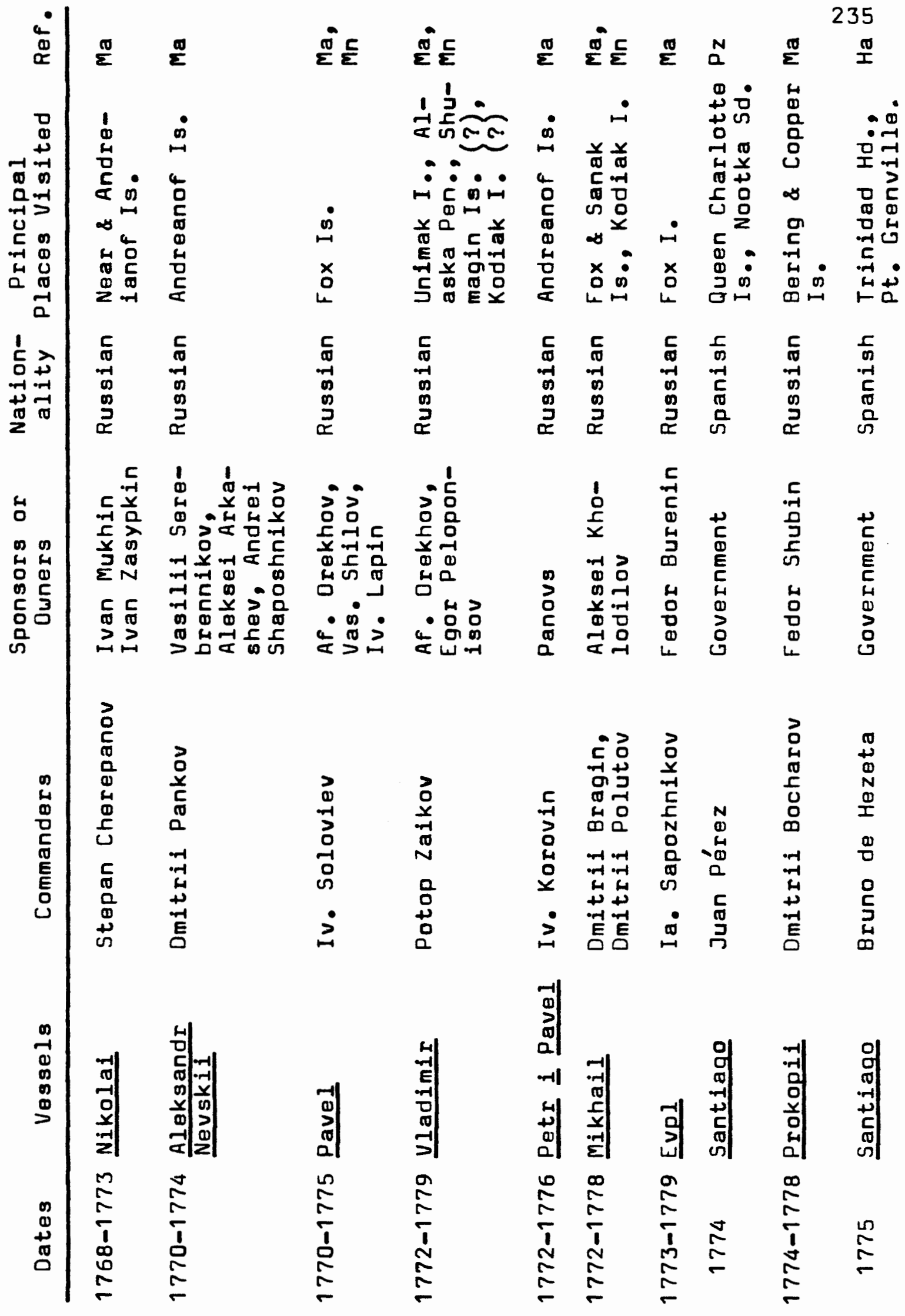




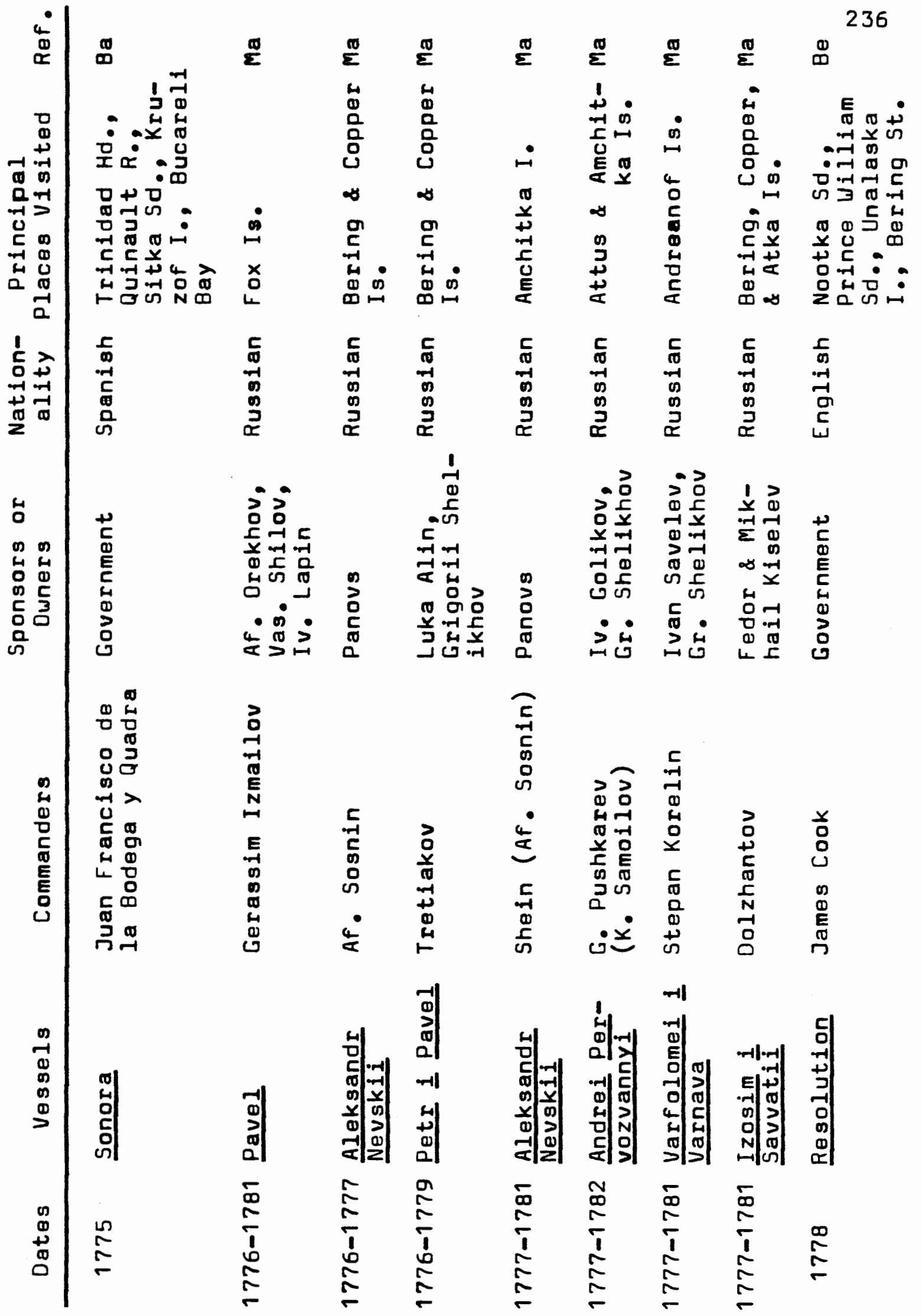




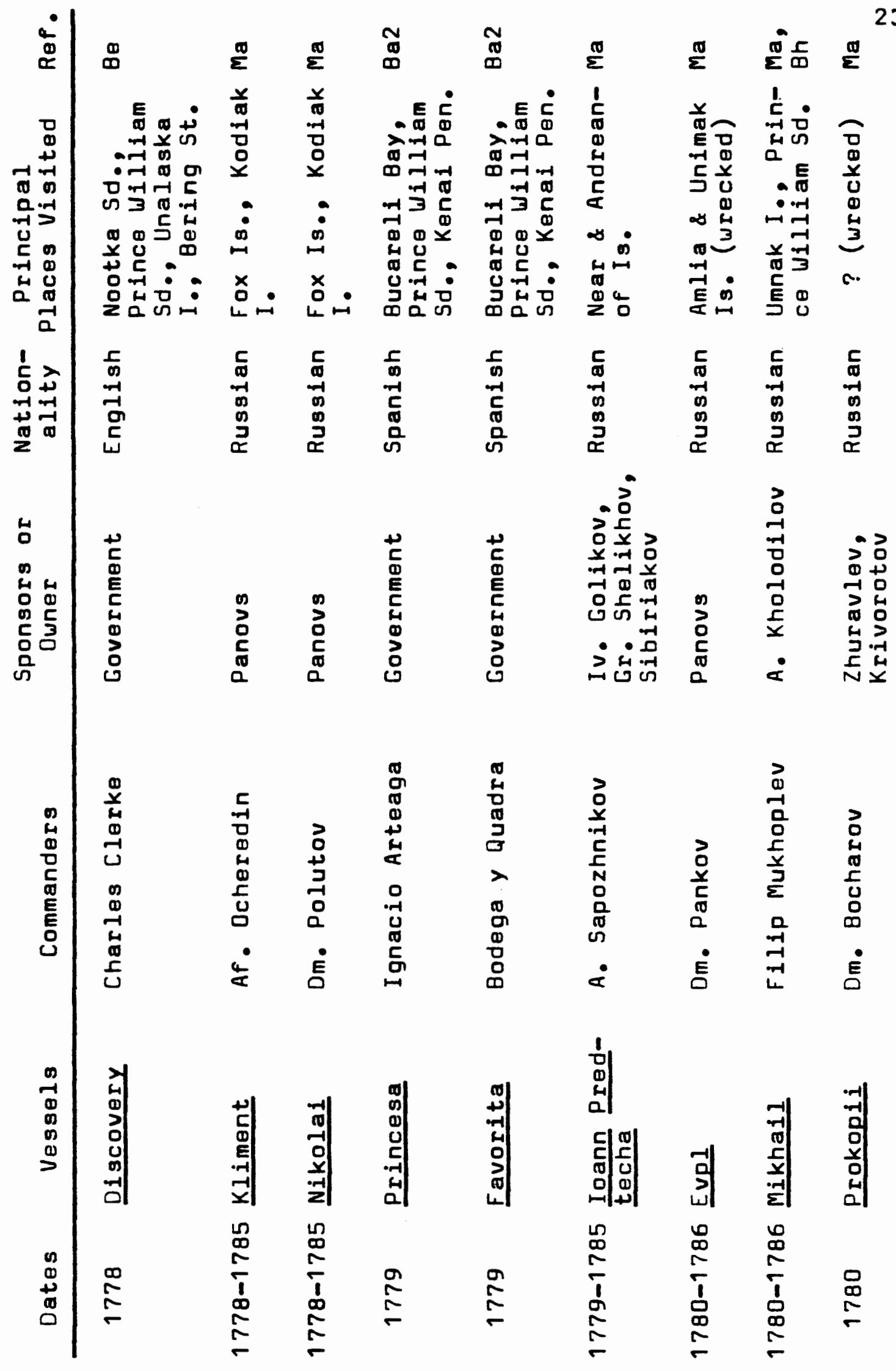




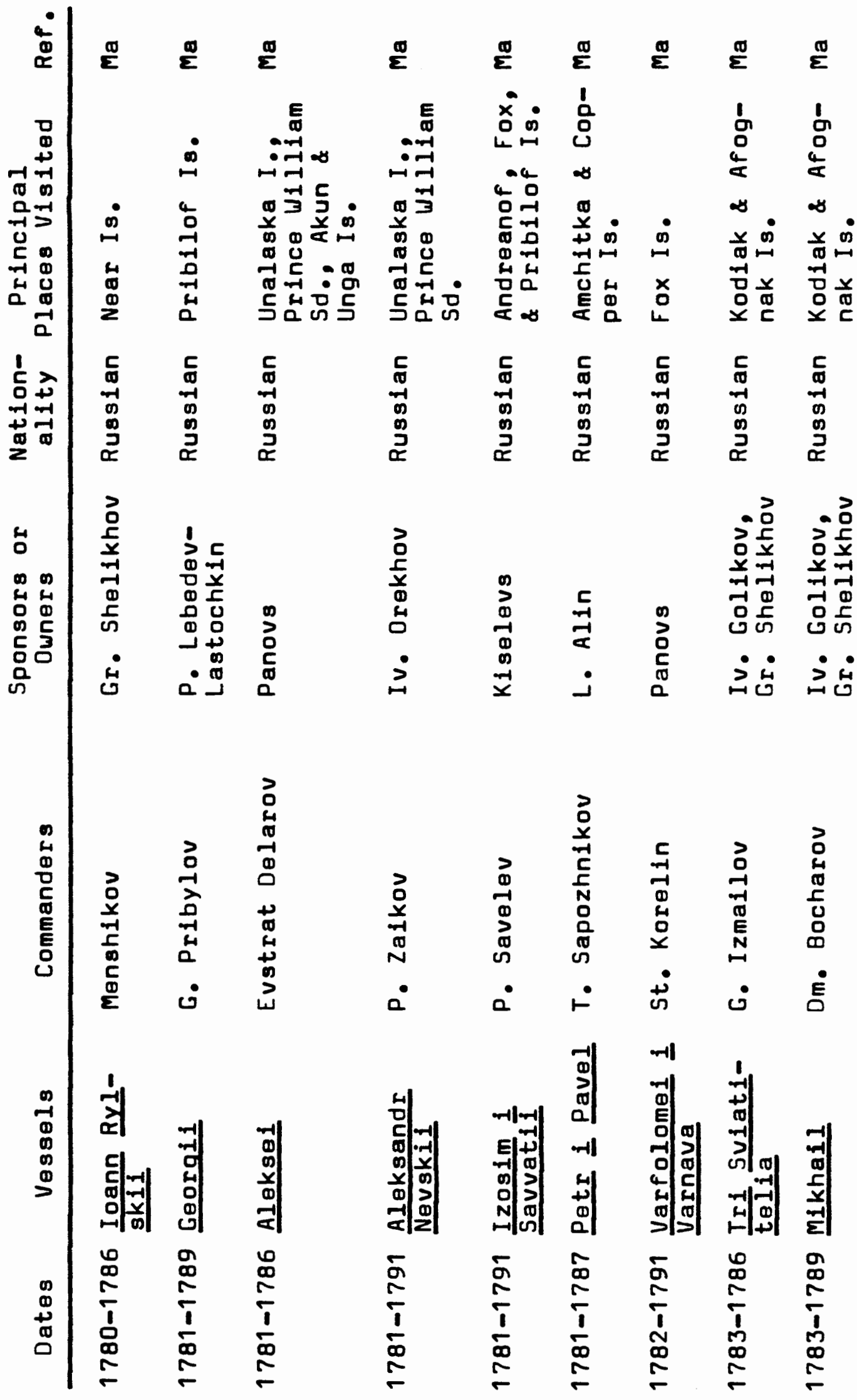




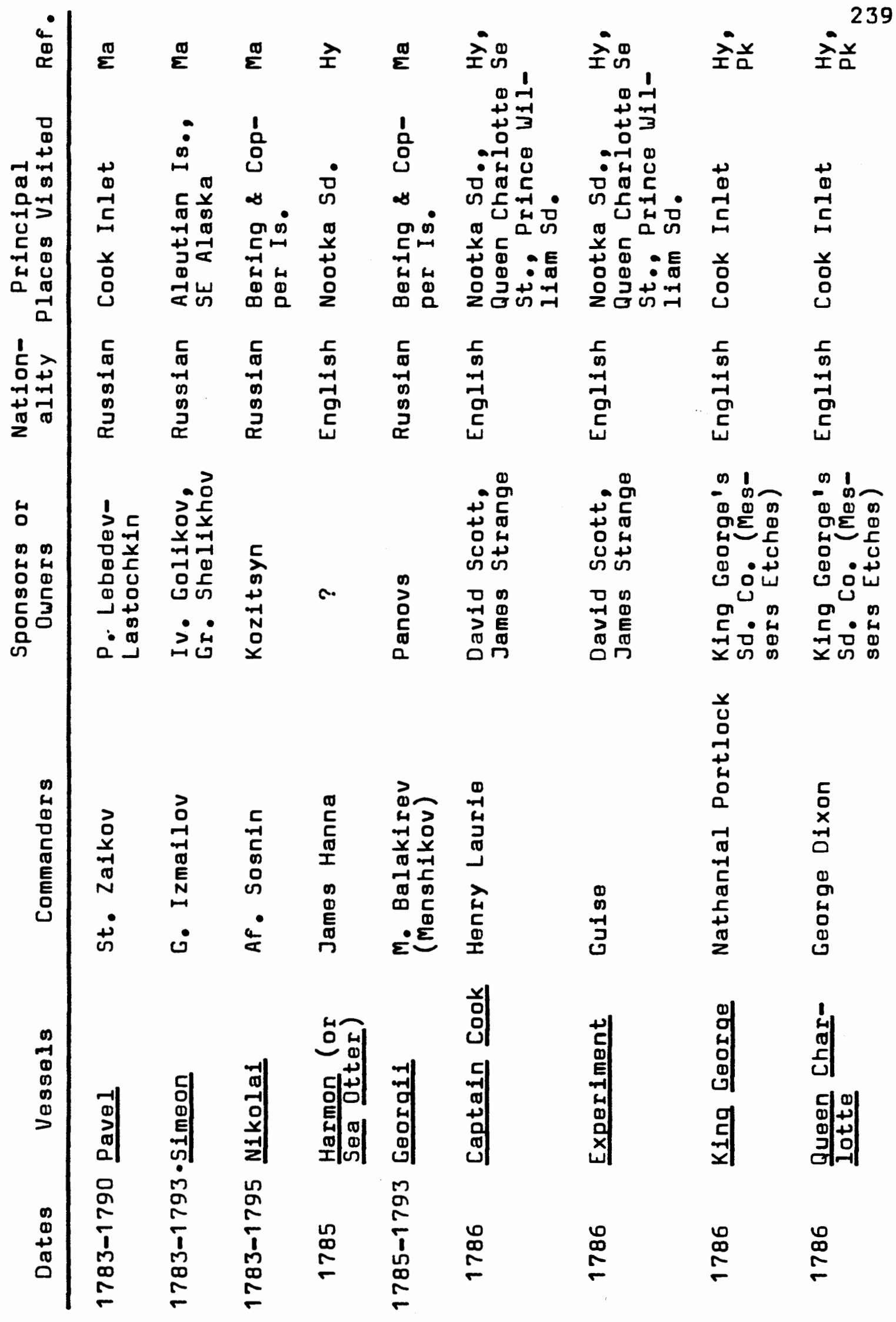




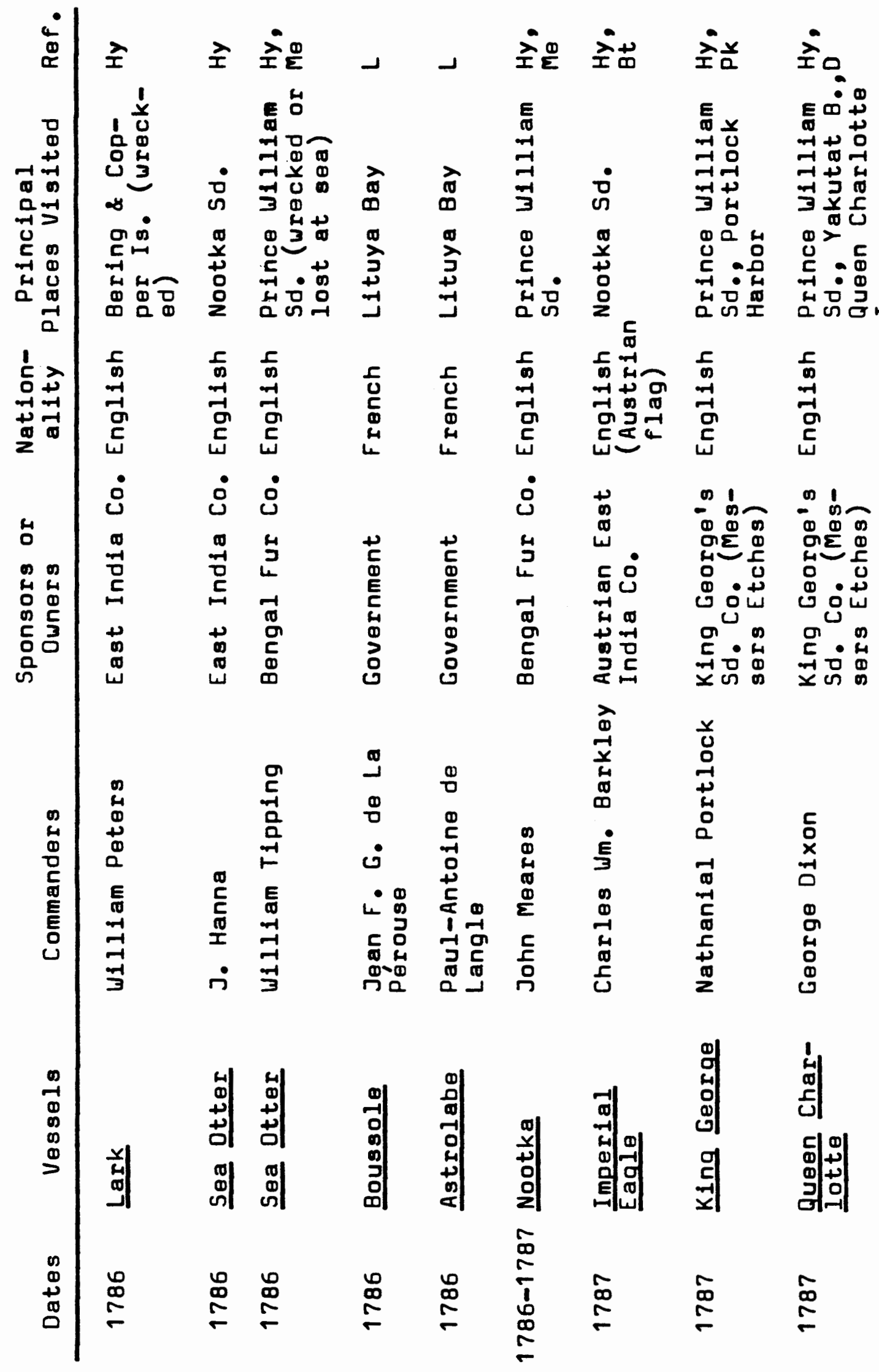




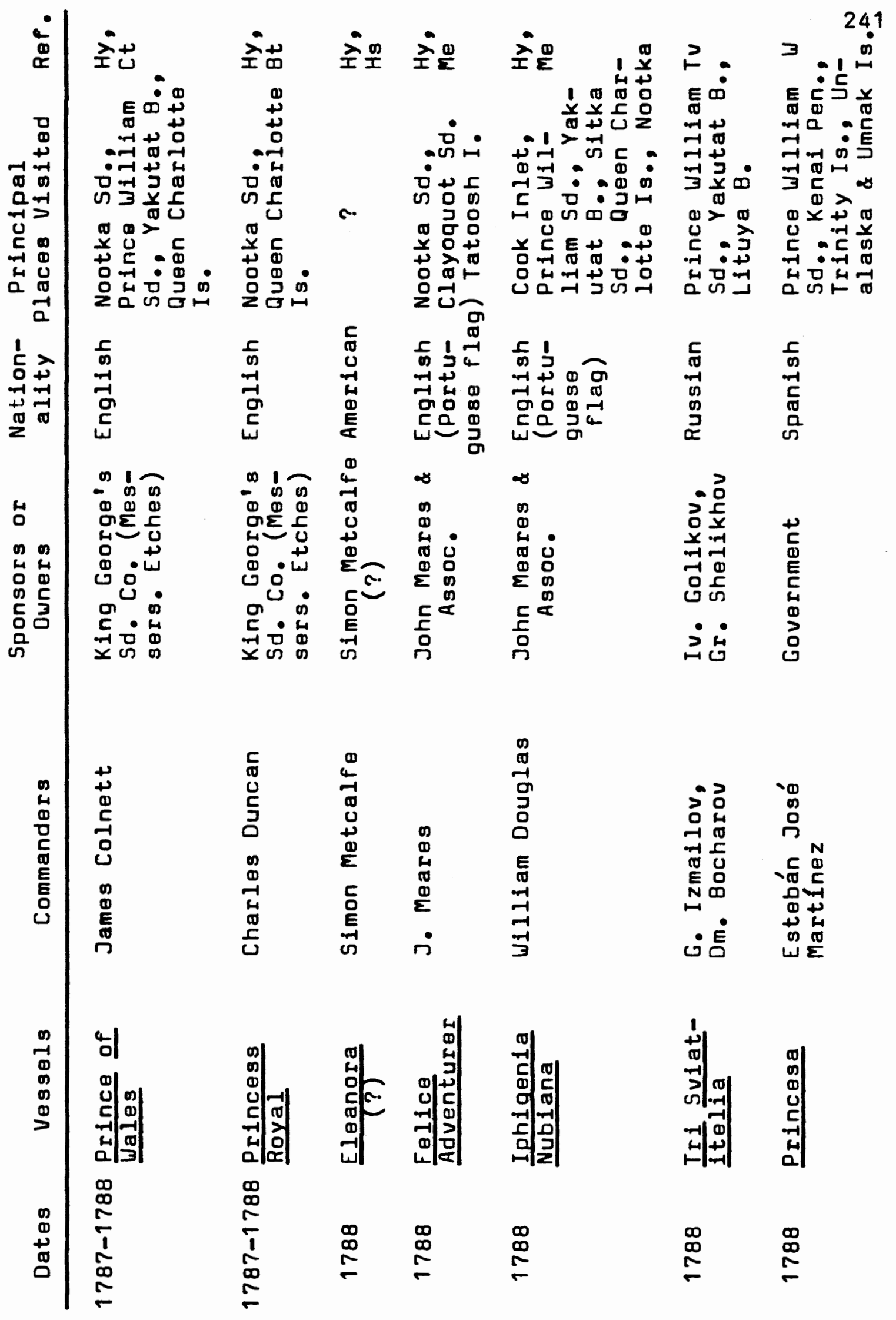




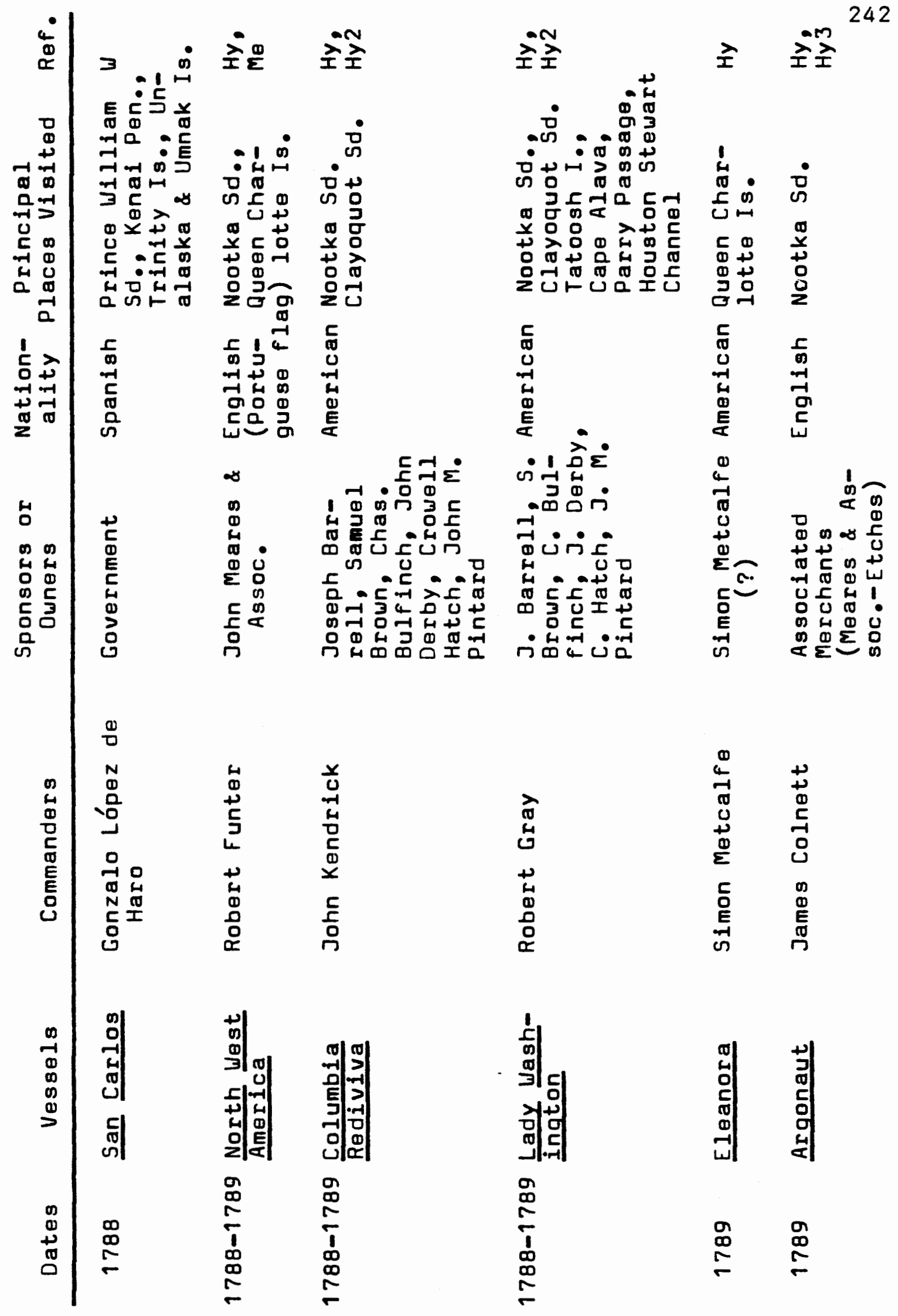




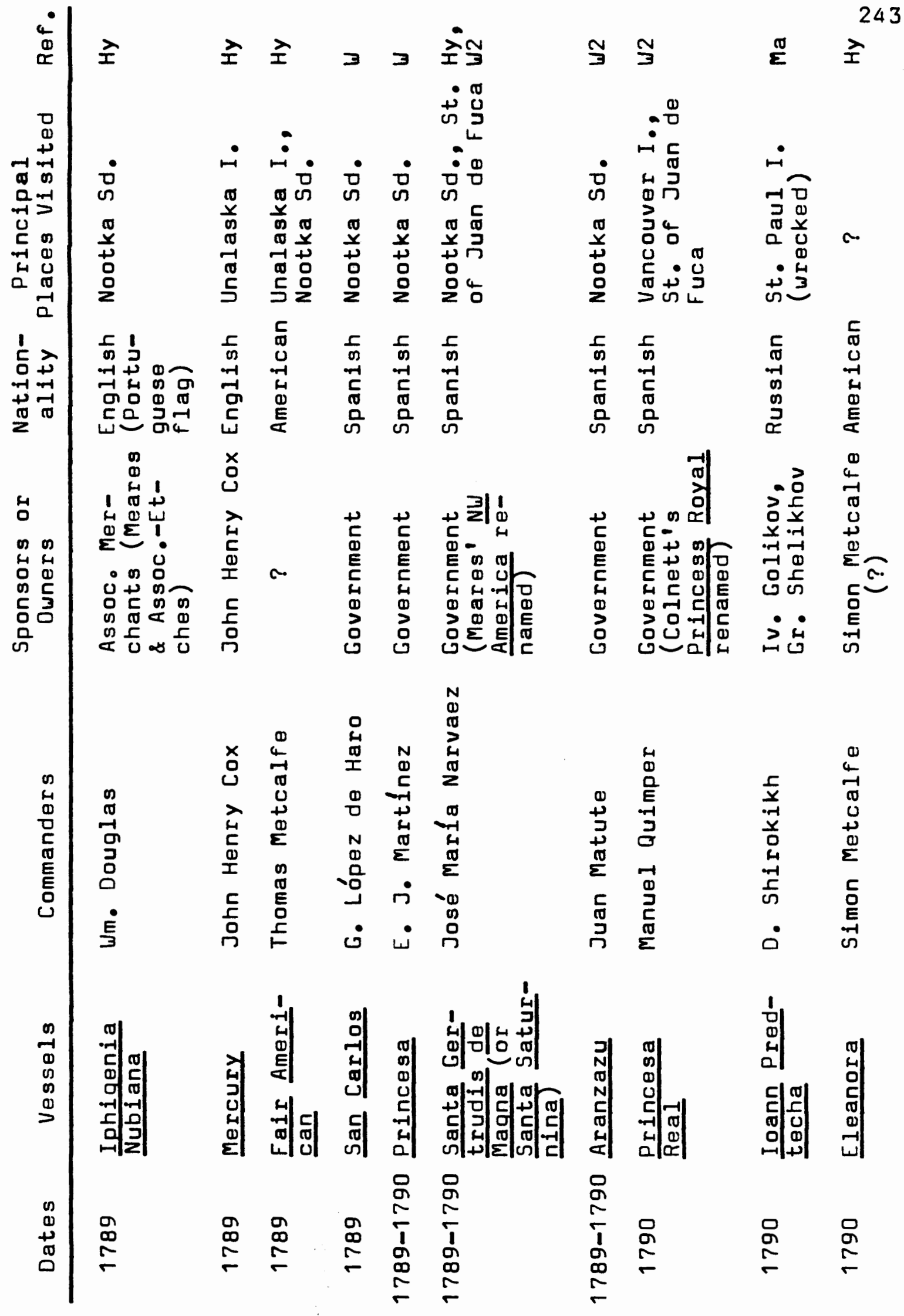




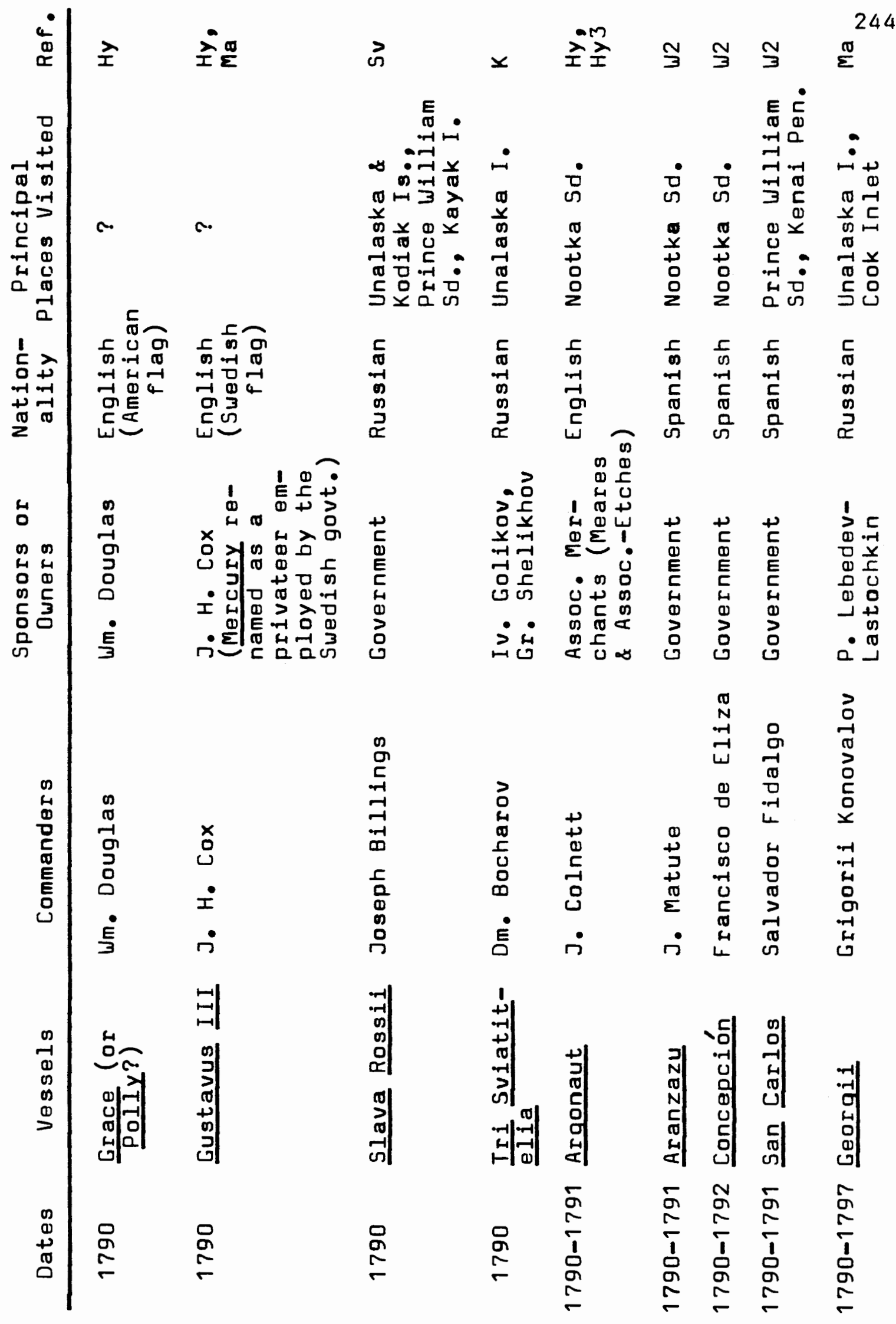




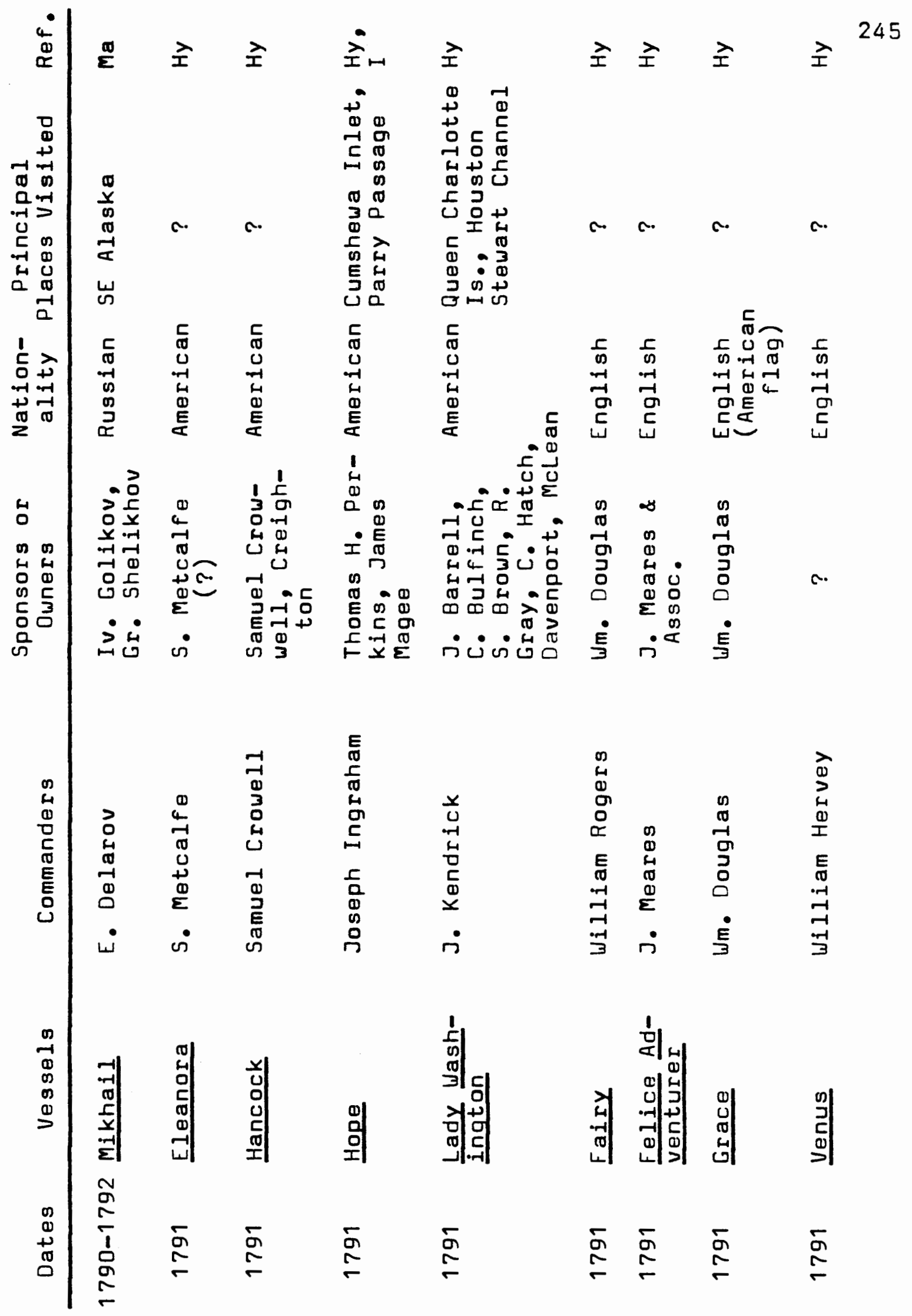




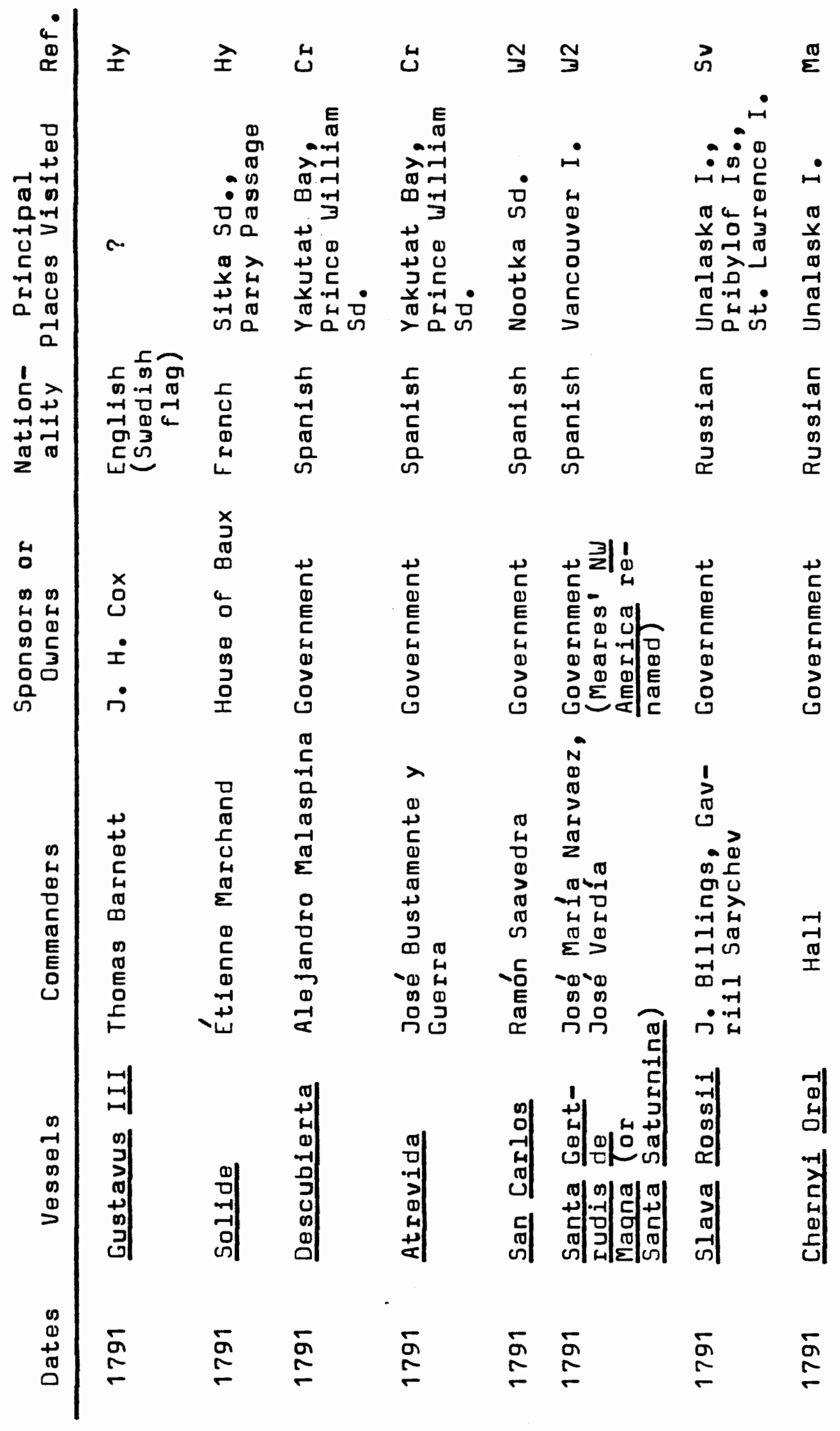




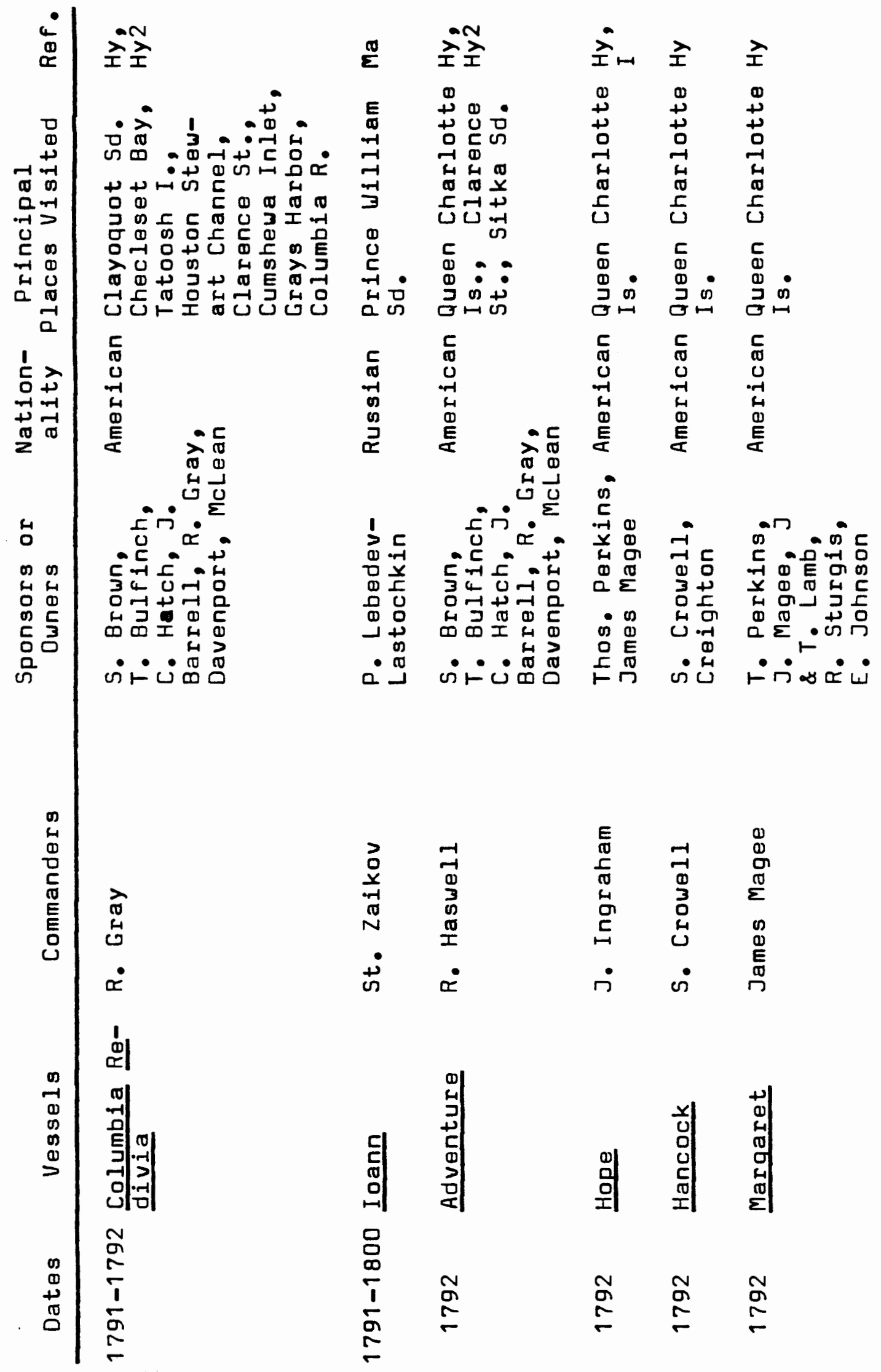




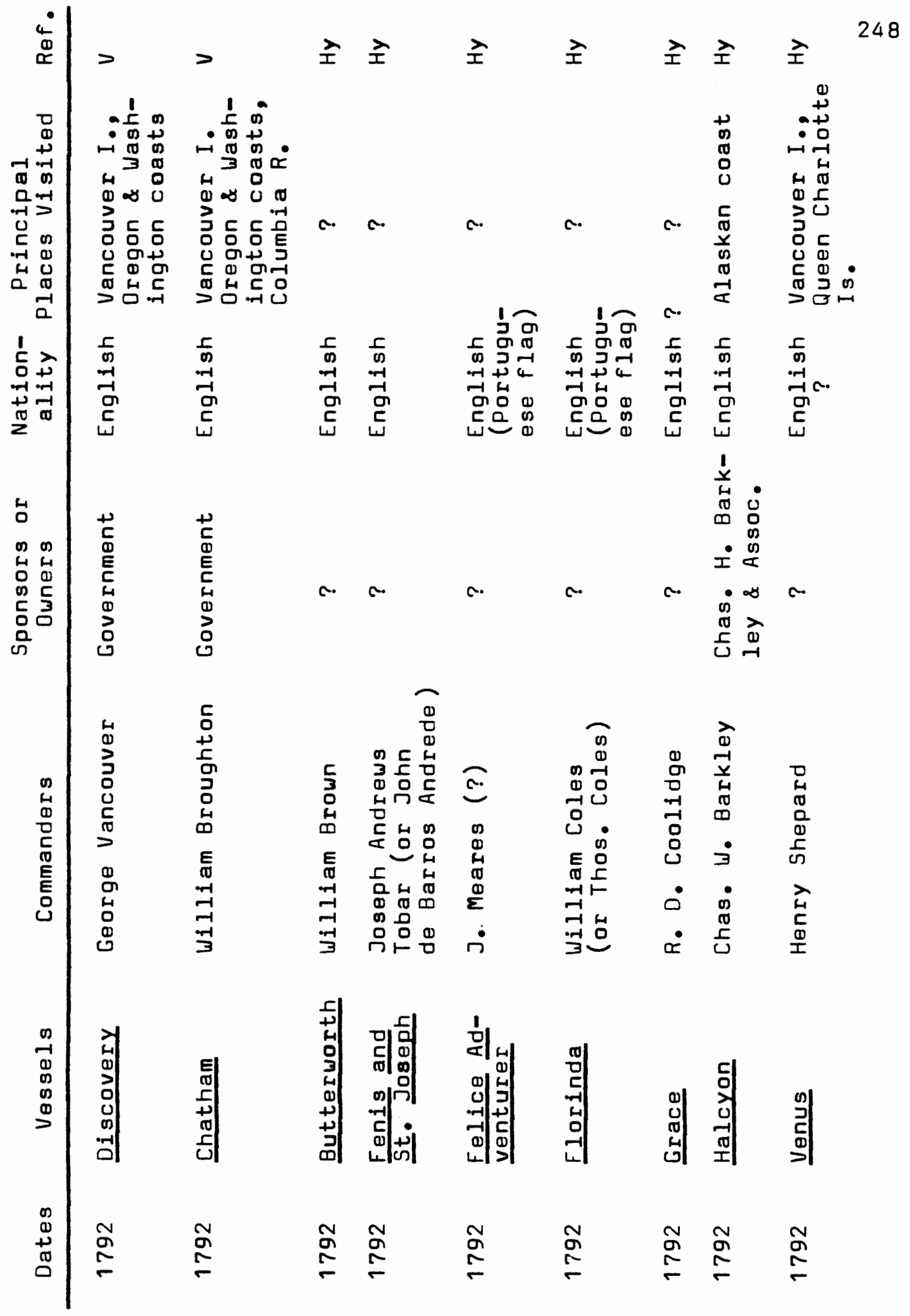




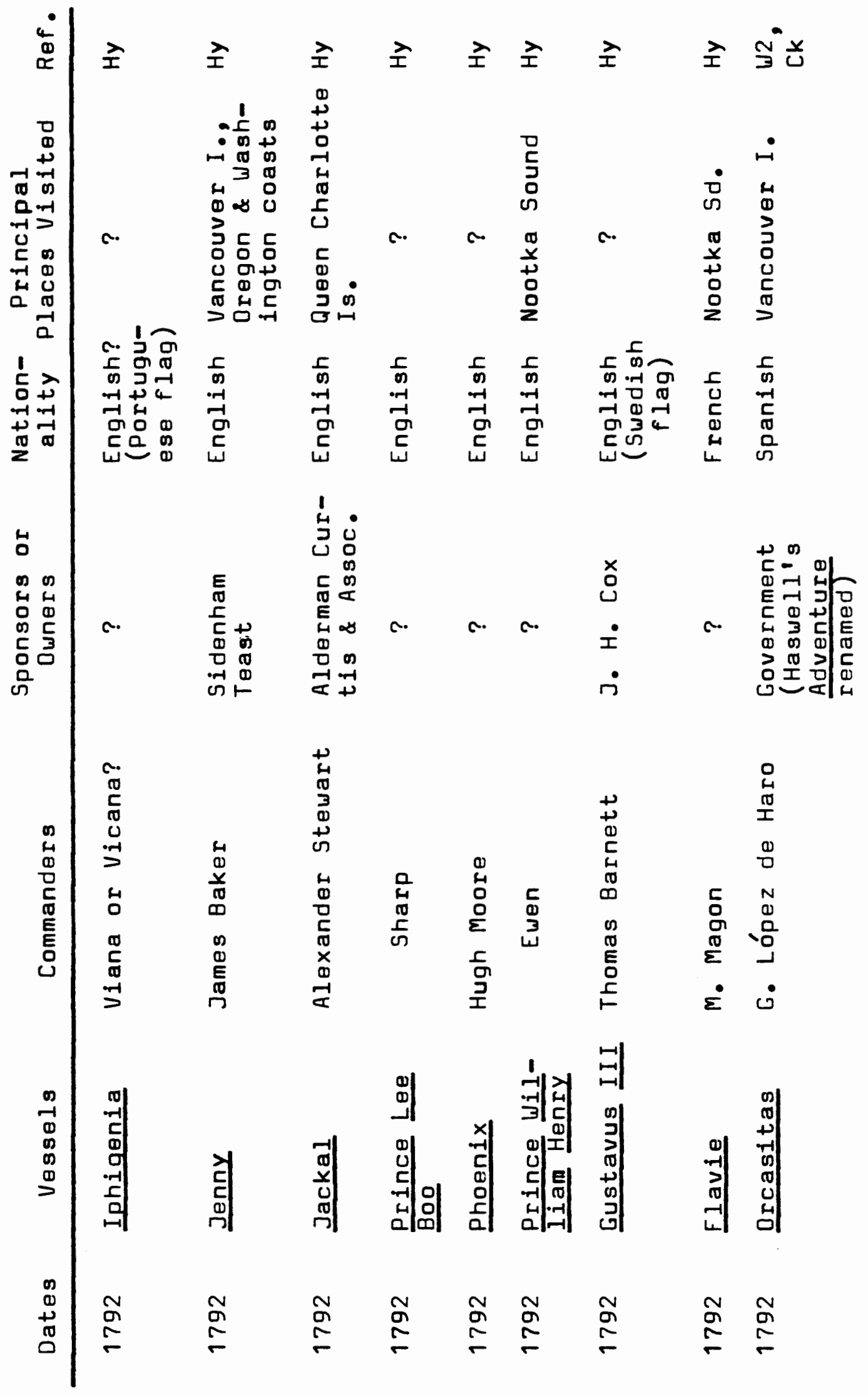

249 


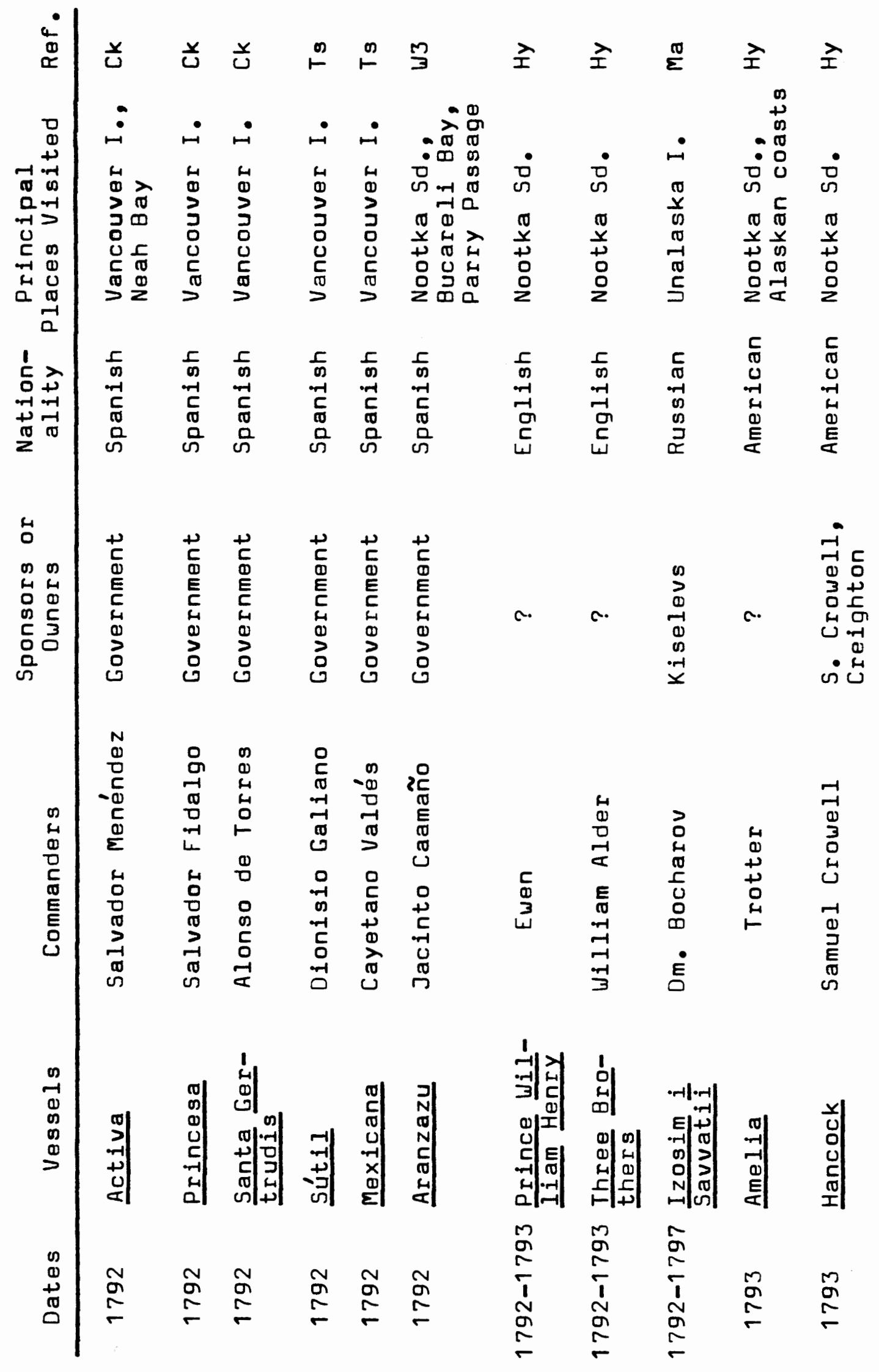




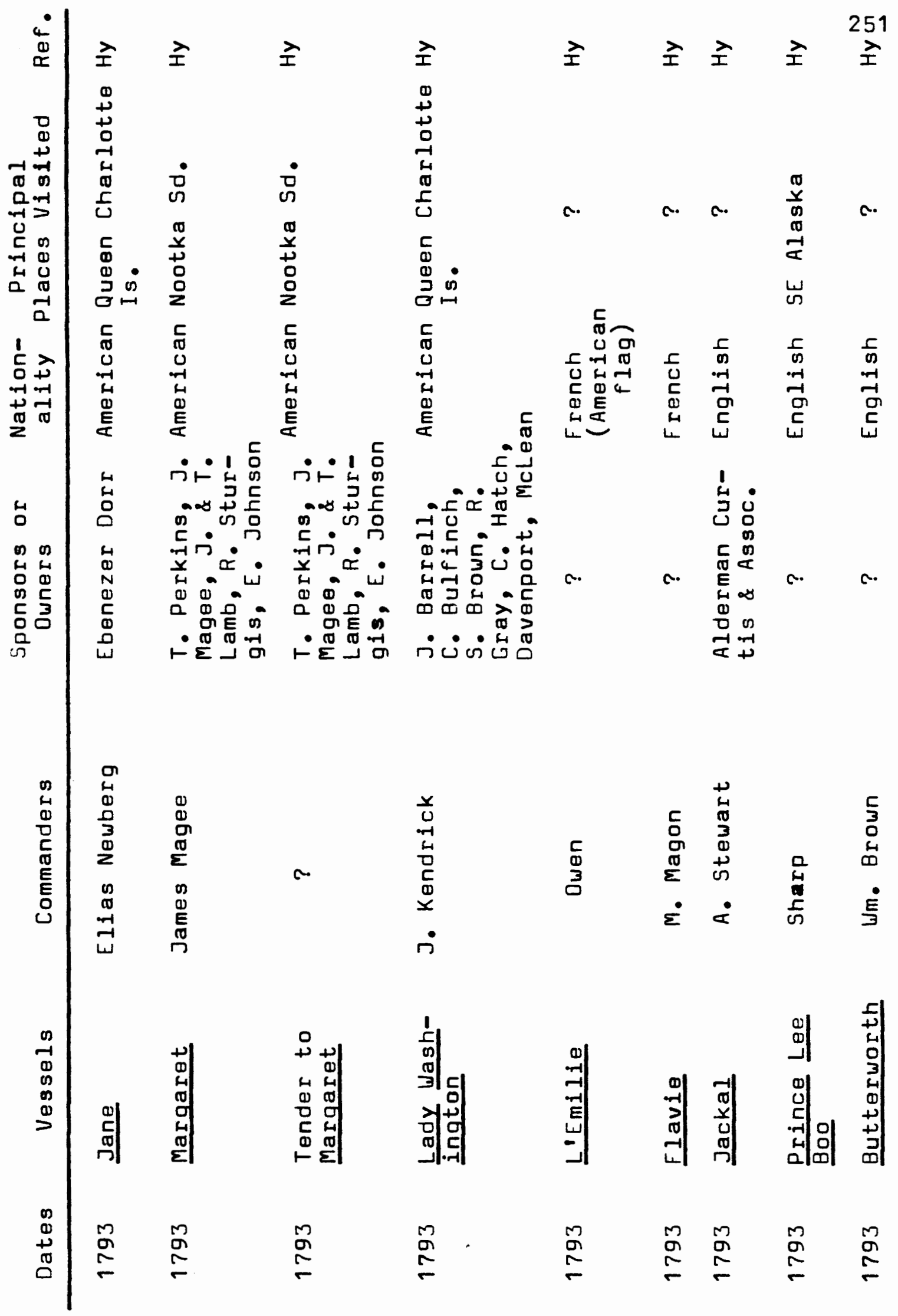




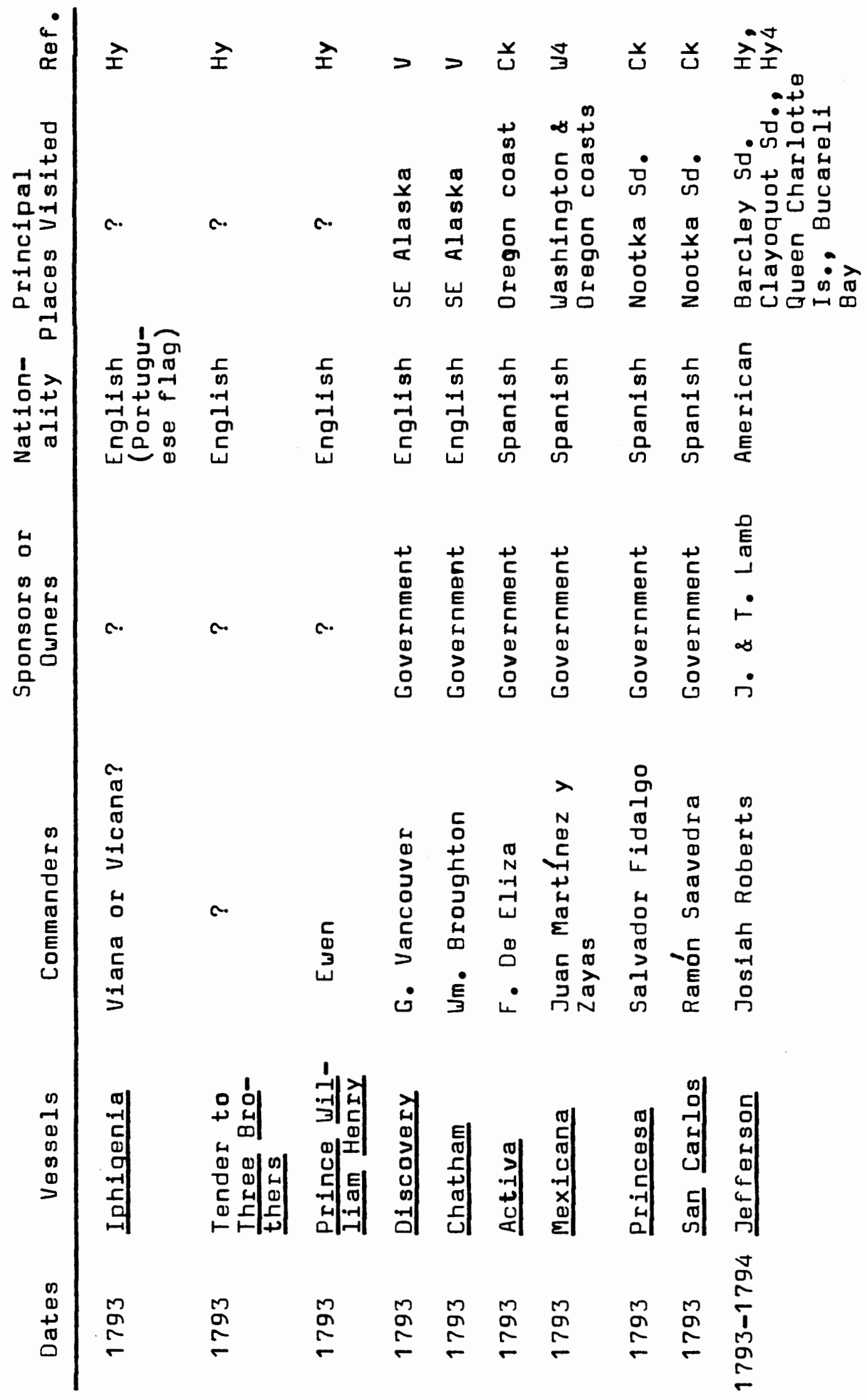




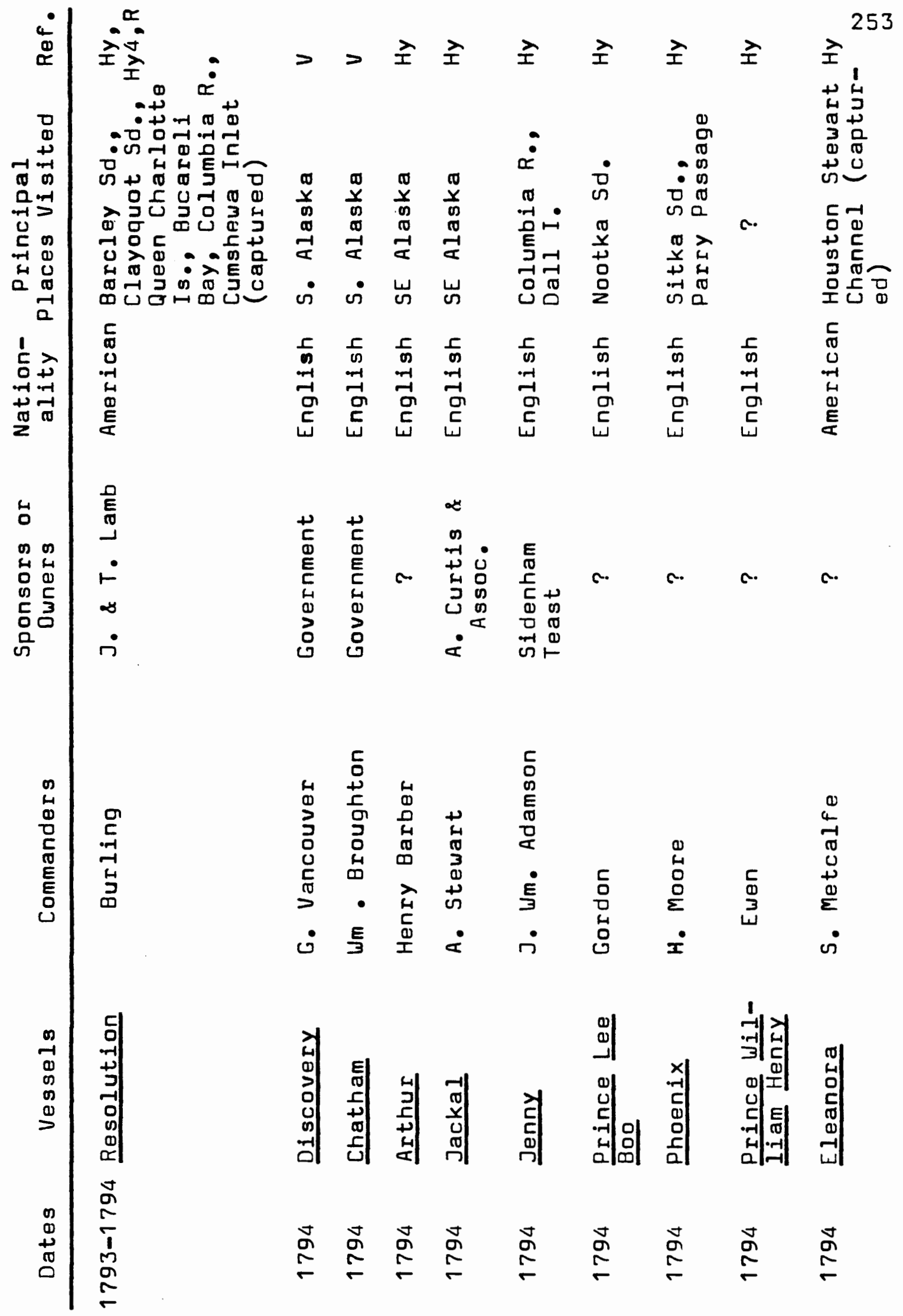




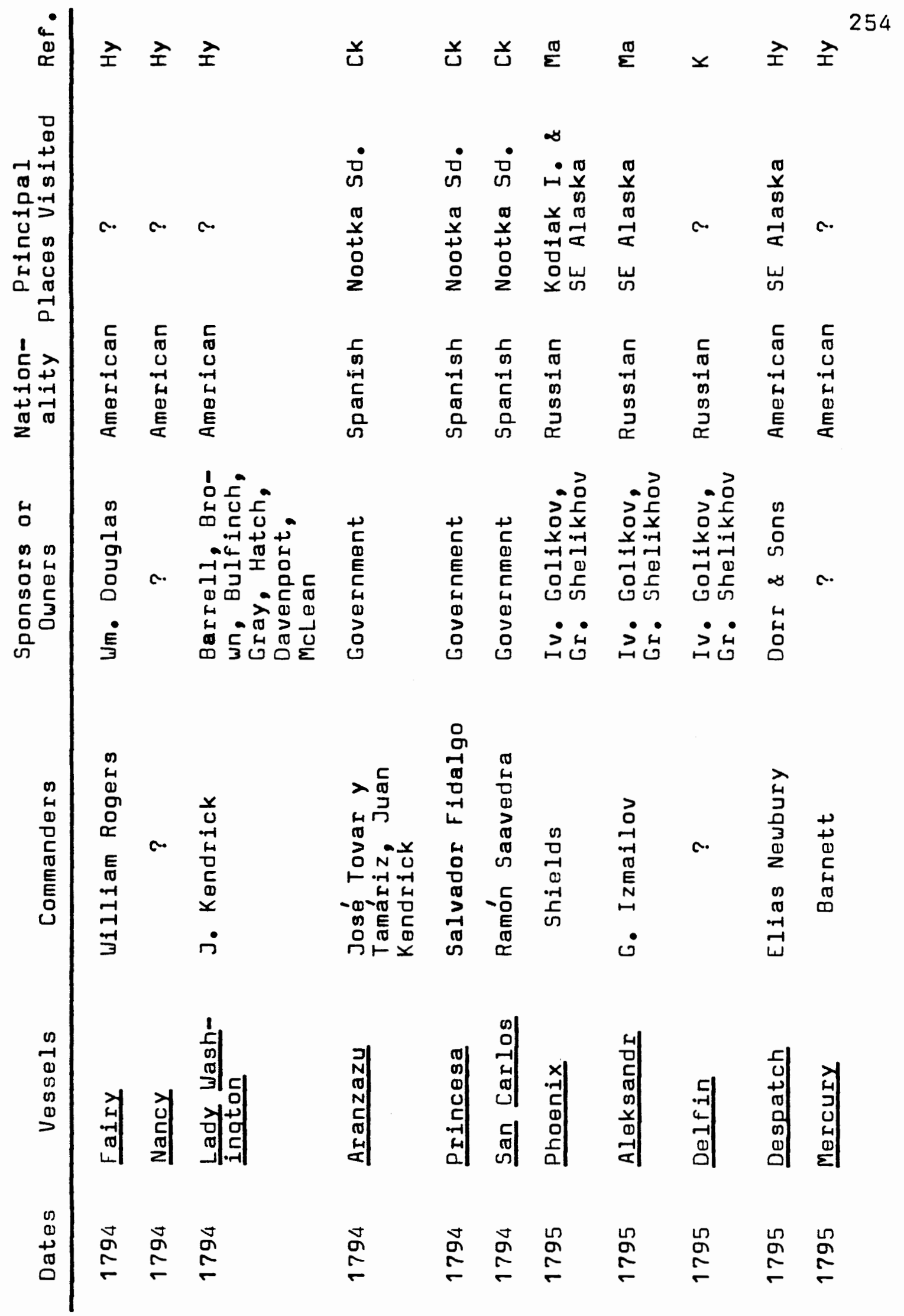




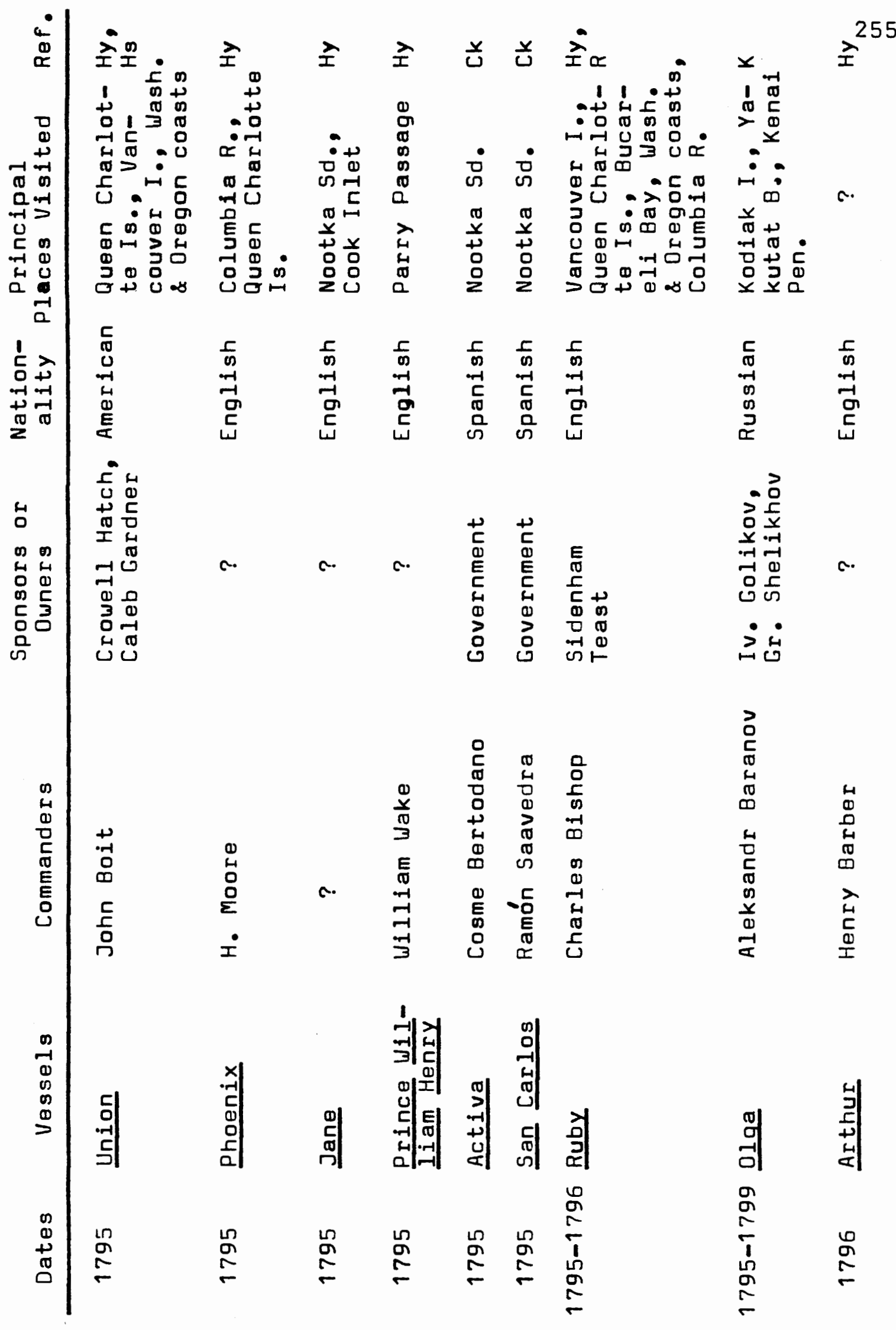




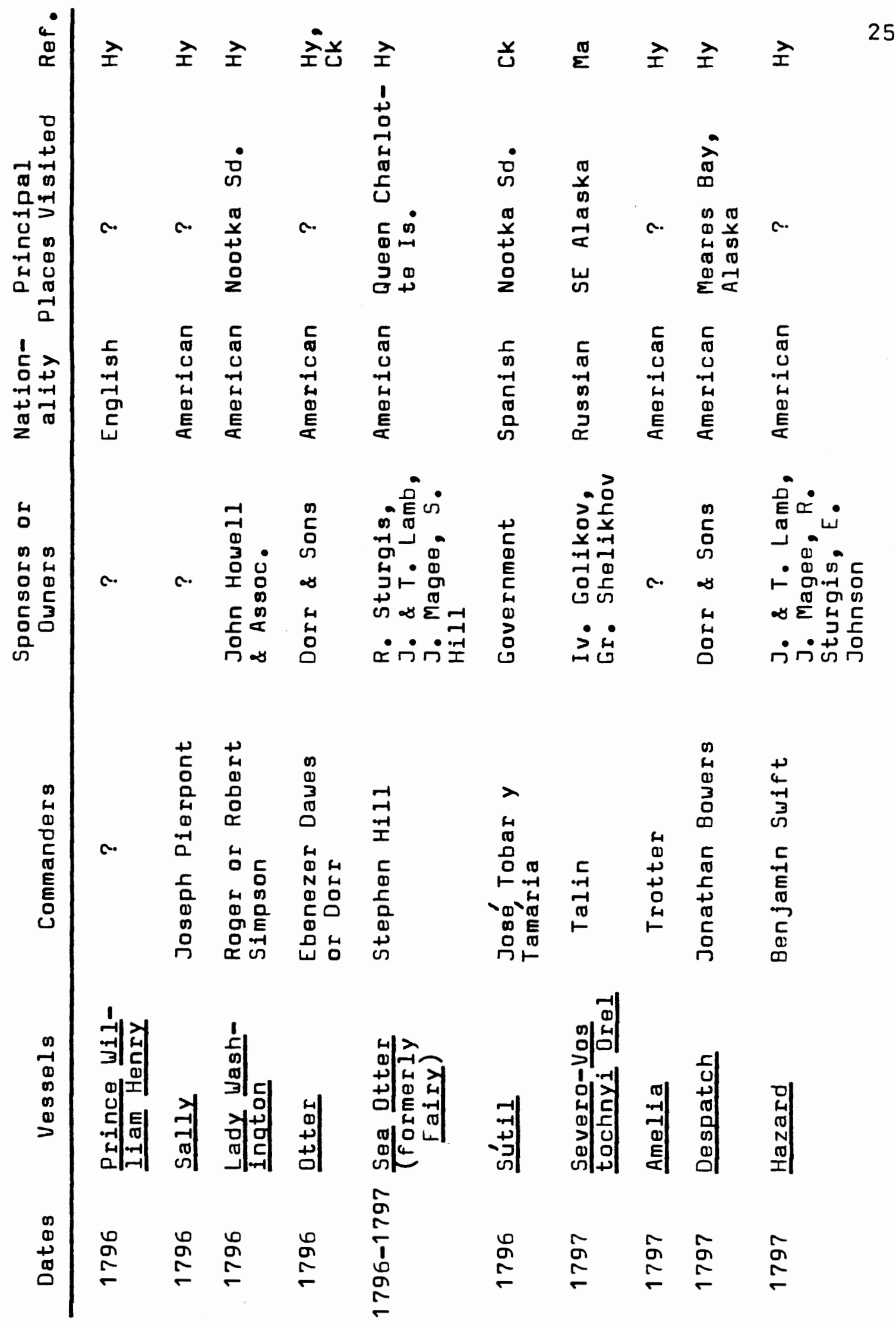




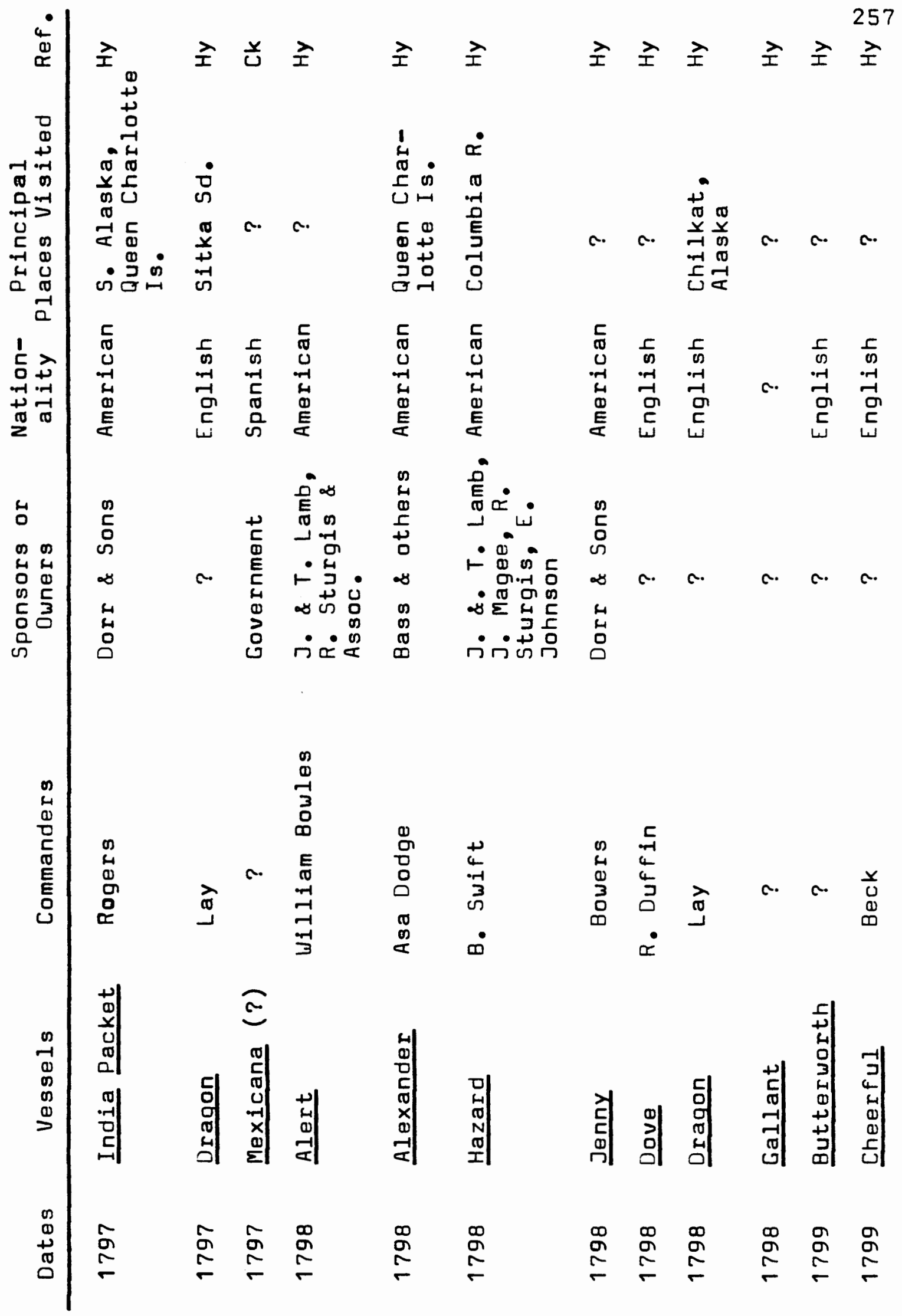




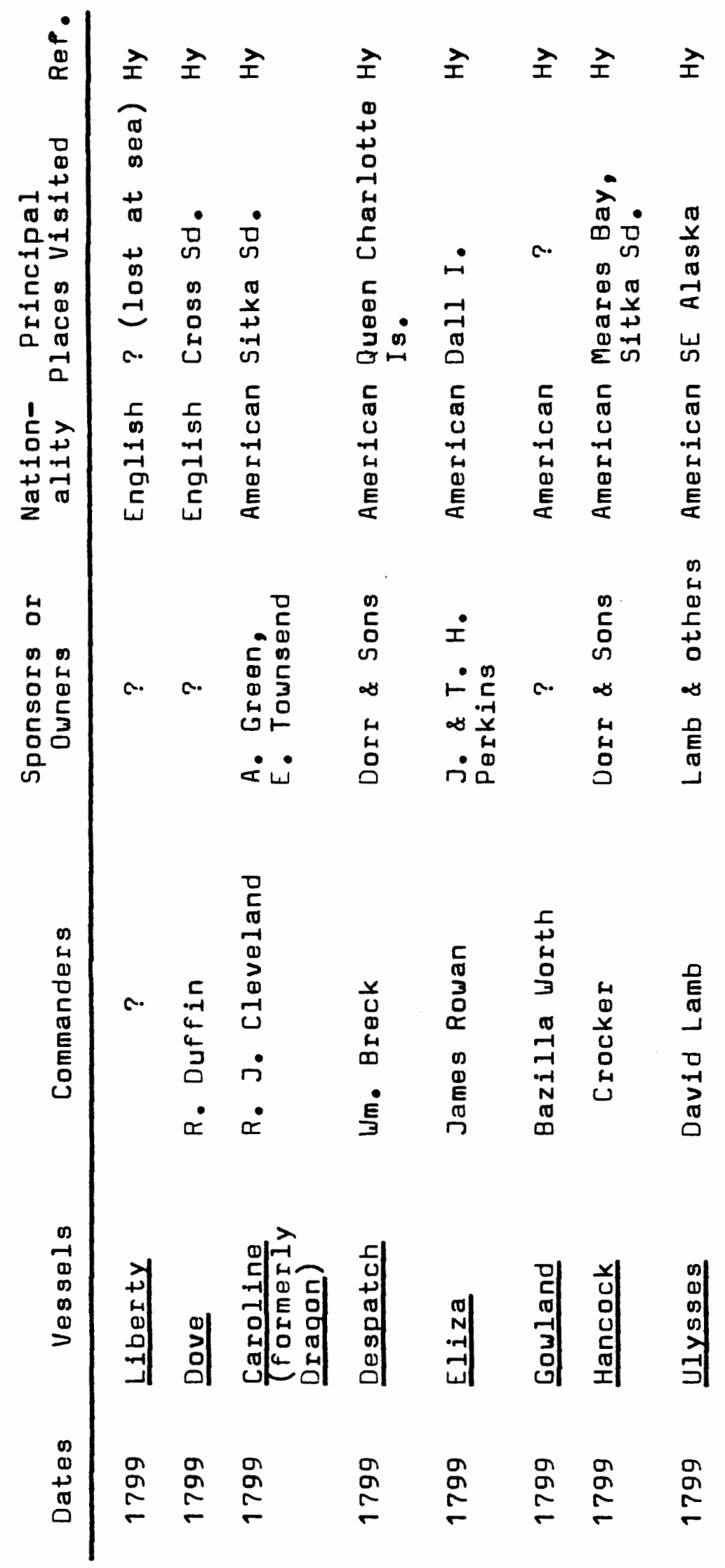




\section{SOURCES CONSULTED}

\section{Unpublished Primary}

Bodega y Quadra, Juan Francisco de la. "First voyage to $58^{\circ}$ in a schooner of 18 cubits keel and 6 beam, manned by a pilot, a boatswain, a mate, ten seamen, a cabin boy and a servant, 1775," trans. G. F. Barwick, 1911. TS in the British Columbia Provincial Archives, Victoria.

in the frigate 'Nuestio señora de los Remedios' [alias] 'La Favorita', of 39 cubits keel and 13 beam, stern draught $14 \mathrm{ft}$. , and prow draught 13 ; year 1779," trans. G. F. Barwick, 1911. TS in the British Columbia Provincial Archives, Victoria.

Britukov, Miron. Report to Navy Captain of the Second Rank Billings, at Yakutsk, November $8[(0.5)],$.1788 , included in "Confidential report of Acting GovernorGeneral of Irkutsk and Kolyvansk, Ivan Peel, to the Ruling Senate, 1210, Irkutsk, September 19 [(0.S.)], $1789, "$ trans. anon. Library of Congress Golder Collection, Transcripts, Box 3. Russian Archives of the State, Petrograd, 1789, VII, \#2742. TS copy in Oregon Historical Society collection, Portland.

Colnett, James. "Journal of the 'Prince of Wales', Dctober 16, 1786 - November 7, 1788." Public Record Office, London, Adm. 55/146. Microfilm copy in the University of Washington Library, Seattle.

Hezeta y Dudagoitia, Bruno de. Miario de la Navegación hecha por el Teniente de Navió de la Real Armada Don Bruno de Hezeta a explorar la costa septentrional de Californias, Año de 1775." Historia tomo 324 , numero 3 y 4. MSS in Archivo General de la Nación, Mexico City; and legajo 19, documento 11, MS in Archivo General de Indias, Seville. Microfilm copies in Oregon Historical Society collection, Portland.

Iakobi, Ivan. "Secret Instructions from Lieutenant-General Iakobi to the Representative of Shelikhov, Samoilov and Delarov. June $21[(0.5)],. 1787 . "$ TS in Oregon Historical Society collection attributed to Tikhmenev, [P. A.], II, Appendix, PP. 21-23, trans. anon.

Krenitsyn, Petr $K$. and Mikhail D. Levashov. MExtract from the Journal of Navy Captain P. K. Krenitsyn and Cap- 
tain-Lieutenant M. D. Levashov describing Russian hunting techniques and native encounters, 1771," trans. E. A. P. Crownhart-Vaughan. TS in Oregon Historical Society collection, Portland, of a translation into English of Divin, Russkaia Tikhookeanskaia epopeis, Khabarovsk, 1971, No. 77, pp. 357-362.

Pérez Hernández, Juan Joseph. "Continuación del Diario que forma el Alferez graduado de Fragata Don Juan Pérez, Primer Piloto del Departmento de San Blas, con la titulada Santiago, alias la Nueva Galicia de su mando, que comprehende su salida de Monterey a explorar la Costa Septentrional, y su regreso a ésta propio Puerto en 26 de Agosto de ésta año de 1774." Estado 38A, Numero 3. MS in Archivo General de Indias, Seville. Microfilm copy in Oregon Historical Society collection, Portland.

Shelikhov, Grigorii Ivanovich. TS English translation by Basil Dmytryshyn and E. A. P. Crownhart-Vaughan of an extract from Rossiiskono kuptsa Grigorii Shelikhova stranstvovania iz Okhotska po Vostochnomu Okeanu k Amerikanskim bereqam, Khabarovsk, 1971, pp. 35-61. TS in Oregon Historical Society collection, Portland.

\section{Published Primary}

Andreyev, A. I., ed. Russian Discoveries in the Pacific and in North America in the Eighteenth and Nineteenth Centuries, trans. Car l Ginsburg. Ann Arbor, Mich.: J. W. Edwards for the American Council of Learned Societies, 1952.

Barry, J. Neilson, ed. "Columbia River Exploration, 1792, II," part of a journal believed to have been written by Edward Bell, clerk of Broughton's ship Chatham. Oreqon Historical Quarterly, 33, No. 2 (1932), pp. 143-155.

Beaglehole, J. C., ed. The Journals of Captain James Cook on his voyages of Discovery. 3 vols. Cambridge: The Hak luyt Society, 1967 .

Boas, Franz. Chinook Texts. Washington, D. C.: U. S. Government Printing Office, 1894.

Campa Cos, Fray Miguel de la. A Journal of Exploration Northward along the coast from Monterey in the year 
1775, ed. John Galvin. San Francisco: John Howell,

Coxe, William. Account of the Russian Discoveries between Asia and America. London: T. Cadell, 1780 Trpt. Readex, 1965$)$.

Cutter, Donald C., ed. The California Coast: A Bilinqual Edition of Documents from the Sutro Collection, trans. George Butler Griffin and Donald C. Cutter. Norman: University of Oklahoma Press, 1969.

Journal of Tomás de Surla of His Voyage with Malaspina to the Northwest coast of America in 1791, trans. Henry R. Wagner. Fairfield, Wash.: Ye Galleon Press, 1980.

Davydov, Gavriil I. Two Voyages to Russian America, 18021807, trans. Colin Bearne, ed. Richard A. Pierce. Kingston, Ontario: The Limestone Press, 1977.

Dixon, George, and William Beresford. A Voyage Round the World; but more Particularly to the North-west coast of America: Performed in 1785, 1786, 1787, and 1788. London: Geo : Goulding, $17 \overline{89}$ 'rpt. N. Israel/Da Capo Press, 1968).

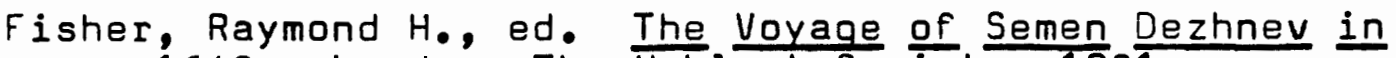
1648. London: The Hakluyt Society, 1981.

Franchère, Gabriel. Adventure at Astoria, 1810-1814, trans. and ed. Hoyt $C$. Franchere. Norman: University of OKlahoma Press, 1967.

Golder, Frank A., ed. Bering's Voyages: An Account of the Efforts of the Russians to Determine the Relation of Asia and America, 2 vols. New York: Dctagon Books, 1968.

Hayes, Edmund, ad. Lon of the Union, John Boit's Remarkable Voyage to the Northwest Coast and Around the World, 1794-1796. Portland: Dregon Historical Society, 1981 .

Heizer, Robert, and John E. Mills, eds. The Four Ages of Isurai: A Documentary History of the Indian Village on Trinidad Bay, trans. of Spanish documents, Donald C. Cutter. Berkeley and Los Angeles: University of California Press, 1952.

Howay, Fredrick W., ed. The Journals of Captain James 
Colnett aboard the Argonaut from April 26, 1789 to November 3,1791 . Toronto: The Champlain Society, 1940.

Voyages of the "Columbia" to Northwest Coast 1787-1790 and 1790-1793. Boston: The Massachusetts Historical society, 1941.

"A Yankee Trader on the Northwest Coast, 1791-1795" "Washington Historical Quarterly, 21, No. 2 (1930), PP. 83-94.

Ingraham, Joseph. Voyage to the Northwest Coast of North America, ed. Mark D. Kaplanoff. Barre, Mass.: Imprint Society, 1971.

Jane, Cecil, trans. A Spanish Voyage to Vancouver and the North-west Coast of America. London: The Argonaut Press, 1930 (rpt. N. Israel/De Capo Press, 1971).

Krasheninnikov, Stepan Petrovich. Explorations of Kamchatka, North Pacific Scimitar, trans. E. A. P. CrownhartVaughan. Portland: Oregon Historical Society, 1972.

Langsdorff, Georg $H_{\text {. von. Voyages and Travels in Various }}$ Parts of the Uorld, During the Years 1803, 1804, 1805, 1806, and 1807, 2 vols. London: Henry Colburn, 1814 (rpt. Gregg Press, 1968).

La Pérouse, Jean François Galaup de. A Voyage Round the World Performed in the Years $1785, \frac{1786}{17}$, $\frac{1787}{2}$, $\frac{1788}{18}$ by the Boussole and Astrlabe, trans. anon., 2 vols. London: Robinson, Robinson, Edwards, and Payne, 1799 (rpt. N. Israel/Da Capo Press).

Ledyard, John. John Ledyard's Journal of Captain Cook's Last Voyage, ed. James Kenneth Munford and introd. Sinclair H. Hutchings. Corvallis: Oregon State University Press, 1963.

Marchand, Étienne, and C. P. Claret Fleurieu. A Voyage Round the World, Performed During the Years 1790, 1791, and 1792: - Preceded by a Historical Introduction and Iliustrated by Charts etc., trans. London: T.N. Longman and O. Rees, Paternoster-Row; and T. Cadell, Jun. and W. Davies, 1801.

Masterson, James R., and Helen Brower, eds. Bering's Successors 1745-1780, Contributions of Peter Simon Pallas to the History of Russian Exploration toward Alas-

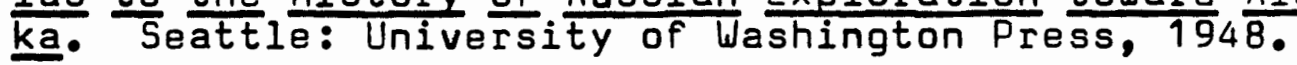


Meares, John. Voyages Made in the Years 1788 and 1789 from China to the North West coast of America. To which are prefixed, An Introductory Narrative of a voyage performed in 1786 , from Bengal, in the ship Nootka; observations on the probable existence of a Northwest Passage; and some account of the trade between the North West Coast and China; and the latter country and Great Britain. London: Logographic Press, 1790 Trpt. N. Israel/De Capo Press, 1967).

M'Leod, John. The Voyage of the Alceste to the Ryukyus and Southeast Asia. Rutiand, Vermont and Tokyo: Charles E. Tuttle Co., 1963.

Morga, Antonio de. Sucesos de las Islas filipinas, trans. and ed. J. S. Cummins. Cambridge: The Hakluyt Society, 1971 .

Mourelle, Francisco Antonio. Voyage of the Sonora in the Second Bucareli Expedition, trans. Daines Barrington, ed. Thomas C. Russell. San Francisco: Thomas C. Russeil, 1920.

Moziño, José Mariano. Noticias de Nutka: An Account of Nootka Sound in 1792, trans. and 8 . Iris Higbie wilson. Seattle and London: University of Washington Press, 1970.

Palóu, Fray Francisco. Relación historica de la vida y apostólicas tareas del venerable padre fray Junípero Serra. Mexico City: Felipe de Zúñiga y Ontiveros, 1787 (rpt. Readex, 1966).

Parker, Samuel. Journal of an Exploring Tour Beyond the Rocky Mountains. Minneapolis: Ross and Haines, 1967.

Penzer, N. M., ed. The World Encompassed and Analogous Contemporary Documents Concerning Sir Francis Drake's Circumnavination of the World. New York: Cooper Square Publishers, 1969 .

Portlock, Nathaniel. A Voyage Round the World; but more particularly to the Northwest coast of America: performed in 1785, 1786, 1787, and 1788 in the King Georqe and Queen Charlotte. London: John Stockdale, 1789.

Roe, Michael, ed. The Journal and Letters of Captain Charles Bishop on the North-west Coast of America, in the pacific and in New South wales, 1794-1799. Cambridge: The Hakiuyt Society, 1967. 
Sarychev, Gavriil A. Account of a Voyage of Discovery to the North-East of Siberia, the Erozen ocean, and the North-East sea, trans. anon., 2 vols. London: Richardphillips, 1806 (rpt. N. Israel/Da Capo Press, 1969).

Sauer, Martin. An Account of a Geographical and Astronomical Expedition to the Northern Parts of Russia. London: T. Cadeli, Jun. and W. Davies, in the Strand, 1802 (rpt. titled Expedition to the Northern Parts of Russia, introd. Kenneth L. Holmes, Surrey, England: Richard Publishing Co. Ltd., 1972).

Strange, James. Journal and Narrative of the Commercial Expedition from Bombay to the Northwest Coast of

America, introd. A. V. Venkatarama Ayyer. Fairfield, Wash.: Ye Galleon Press, 1982.

Swanton, John R. Tlingit Myths and Texts. Washington,

D. C.: U. S. Government Printing Office, 1909.

Thorton, Walter, ed. and trans. "An Account by Fray [Juan] Riobo of the Voyage made by the Frigates 'Princesa' and 'Favorita' in the Year 1799 [sic] from San Blas to Northern Alaska," Catholic Historical Review, 4, No. 2 (1918), Pp. 222-229.

Thwaites, Reuben Gold, ed. Oriqinal Journals of the Lewis and Clark Expedition, 7 vols. New York: Dodd, Mead and $\mathrm{Co}_{0}, 1905$.

Turanzas, José Porrua, ed. Relación del viage hecho por las goletas Sútil y Mexicana en el año de 1792 para reconocer el Estrecho de Fuca. Madrid: Artes Graficos Minerva, 1958.

Vancouver, George. A Voyage of Discovery to the North Pacific Ocean and Round the World $*$ Performed in the Years 1790, 1791, 1792, 1793, 1794, and 1795, 6 vols. London: John Stockdale, 1801.

Wagner, Henry R. Sir Francis Drake's Voyage Around the World: its Aims and Achievements, Pt. I I, Documentary. San Francisco: John Howell, 1926.

Spanish Voyages to the Northwest Coast of America in the Sixteenth century. San Francisco: California Historical Society, 1929 (rpt. N. Israel, 1966). 
Strait of Juan de Fuca. Santa Ana, Calif.: Fine Arts Press, 1933 (rpt. AMS Press, 1971).

"The Last Spanish Exploration of the Northwest Coast," California Historical Quarterly, 10, No. 4 (1931), PP. 313-345.

Wagner, Henry R., ed., and A. J. Baker, trans. "Fray Benito de la Sierra's Account of the Hezeta Expedition to the Northwest Coast in 1775," California Historical Quarterly, 9, No. 3 (1930): pp. 201-242.

Wagner, Henry $R_{e}$, and $W_{.} A_{.}$Newcomb, eds. "The Journal of Don Jacinto Caamaño," trans. Harold Grenfell, British Columbia Historical Quarterly, 2, Nos. 3 and 4 (1938), PP. 189-222, 265-301.

Walker, Alexander. An Account of a Voyage to the North West Coast of America in $178 \overline{5}$ and $178 \overline{6}$, eds. Robin Fisher and $\frac{1}{\text { J. M. Bumsted. }}$ Seattle, Vancouver, Toronto: Douglas McIntyre, University of Washington Press, 1982 .

\section{Unpublished Secondary}

Keddie, Grant. "Early Chinese Coins in British Columbia?"
TS copy in author's possession. Nd.

Kenyon, Malcolm H. "Naval Construction and Repair at San Blas, Mexico, 1767-1797," Thesis University of New Mexico, Albuquerque. Nd.

Newman, Thomas. "Tillamook Prehistory and its Relation to the Northwest Coast Culture Area," Diss. University of Oregon, Eugene, 1959.

Woodward, John A. "Salmon, Slaves, and Grizzly Bears: the Prehistoric Antecedents and Ethnohistory of Clackamas Indian Culture," Diss. University of Oregon, Eugene, 1974 .

Mt. Hood Community College Archaeologist, personal communications, October 29, 1982 . 
Published Secondary

Bancroft, Hubert Howe. History of the Northwest Coast, 2 vols. San Francisco: A. L. Bancroft and Co., 1884.

San Francisco: A. L. Bancroft and $\frac{\text { Alaska, }}{0 ., 18}, \frac{1}{1}$

Bandi, Hans-Georg. Eskimo Prehistory, trans. Ann E. Keep. College, Alaska: University of Alaska Press, 1972.

Barnett, Homer G. The Coast Salish of British Columbia. Eugene, Dregon: University of Ore

Beaglehole, J. C. The Exploration of the Pacific. Stanford, Calif.: Stanford University Press, 1968.

Beals, Herbert K. "Chinese Coins: New Evidence," Screeninas, 26, No. $8(1977)$.

"Chinese Coins in Six NorthWestern Aboriginal Sites," Historical Archaeology, 14 (1980), PP. 58-72.

"The Distribution and Use of Asian Coins as Trade Items on the Northwest Coast of America," Contributions to the Archaeology of Qregon, Association of Dregon Archaeologists Dccasional Papers No. 2, 1983.

Beals, Herbert $K_{.}$, and Harvey Steele. "Chinese Porcelains from Site 35-TI-1, Netarts Sand Spit, Tillamook

County, Oregon," University of Oregon Anthropological Papers, No. 23, 1981.

Birket-Smith, Kaj, and Frederica De Laguna. The Eyak Indians of the Copper River Delta, Alaska. Kbbenhavn:

Levin and Munkscaard, 1938 .

Berkh, Vasilii Nikolaevich. A Chronological History of the Discovery of the Aleutian Islands, trans. Dmitrii Krenov, ed. Richard A. Pierce. Kingston, Ontario: The Limestone Press, 1974.

Bolkhovitinov, Nikolai. The Beginnings of Russian American Relations, 1775-1815, trans. Elena Levin. Cambridge, Mass. and London: Harvard University Press, 1975.

Boas, Franz. "A Bronze Figurine from British Columbia," Bulletin of the American Museum of Natural History, 
14 (1901), pp. 50-52.

Bolles, T. Dix. "Chinese Relics in Alaska," Proceedinos $\frac{\text { of }}{22}$ the . . S. National Museum, 15, No. 1 $(1892), \mathrm{P}$.

Brooks, Charles Wolcott. "Report of Japanese Vessels Wrecked in the North Pacific Ocean: From the Earliest Records to the Present Time," Proceedings of the California Academy of Science, No. 6 (1875), pp. $50-66$.

Brown, J. Macmillan. Peoples and $\frac{\text { Problems }}{2 \text { vols. New York: J. H. }} \frac{\text { the }}{\text { Seacs and Co., Inc., }} \frac{\text { Pafic, }}{1927 .}$

Chevigny, Hector. Lord of Alaska, Baranov and the Russian Adventure. New Yo, rk: The VikingPress, 1944.

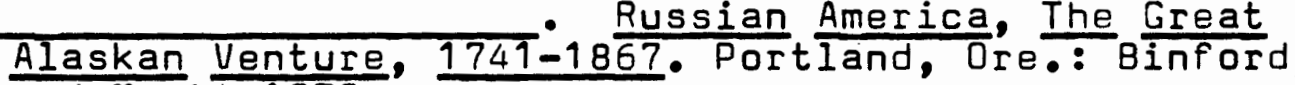
and Mort, 1979.

Clark, Donald w. "Technological Continuity and Change within a Persistent Maritime Adaptation: Kodiak Island, Alaska," Maritime Adaptations of the Pacific, eds. Richard W. Casteel and George I. Quimby. The Hague and Paris: Mouton Publishers, 1975.

Clarke, S. A. Pioneer Days of Dregon History, 2 vols. Portland, Ore.: J.K. Gili Co., 1905.

Cook, Warren L. Flood Tide of Empire, Spain and the Pacific Northwest, 1543-1819. New Haven and London: Yale University Press, 1973.

Couture, $A_{\odot}$, and J. D. Edwards. "Origin of Copper Used by Canadian West Coast Indians in the Manufacture of Ornamental Plaques," Contributions to Anthropology, 1961-1962, Pt. I I, National Museum of Canada Bulletin No. 194. Department of the Secretary of State, Ottawa, Canada, 1964.

Cressman, Luther S. "Lower Columbia Indian Weapons," Oregon Historical Quarterly, 49, No. 4 (1948), pp. $297-$ 298.

Cutter, Donald C. "Spain and the Oregon Coast," The Western Shore: Oregon Country Essays Honoring the American Revolution, ed. Thomas Vaughan. Portland: Oregon Historical Society, 1975.

De Laguna, Frederica. Chugach Prehistory, The Archaeolooy 


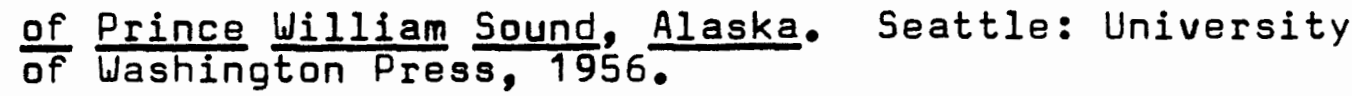

Under Mount Saint Elias: The

History and Culture of the Yakutat Tingit, 3 vols. Washington, D.C.: Smithsonian Institution Press, 1972 .

De Laguna, Frederica, Francis A. Riddle, Donald F. McGeenin, Kenneth S. Lane, and J. Arthur Freed, with a chapter by Carolyn Osborne. Archaeology of the Yakutat Bay Area, Alaska. Washington, D. C.: U. S. Government Printing Dffice, 1964 .

Drucker, Philip. Indians of the Northwest Coast, Anthropological Handbook No. 10 . New York, Toronto, London: The American Museum of Natural History and McGrawHill Book Co., Inc., 1955.

Dumond, D. E. "A Summary of Archaeology in the Katmai Region, Southwestern Alaska," University of Oregon Anthropological Papers No. 2, 1971.

Dunmore, John. French Explorers in the Pacific, 2 vols. Oxford: The Clarendon Press, 1965.

Emmons, G. T. "Native Account of the Meeting Between La Pérouse and the Tlingit," American Anthropologist, N. S., 13 (1911), Pp. 294-298.

Fedorova, Svetlana G. The Russian Population in Alaska and California: Late 18th Century - 1867, trans. and eds. Richard A Pierce and Alton S. Donneliy. Kingston, Ontario: The Limestone Press, 1973.

Fisher, Raymond $H$. Bering's Voyages: Whither and Why? Seattle and London: University of Washington Press, 1977 .

"Semen Dezhnev and Professor Golder," Pacific Historical Review, 25, No. 3 (1956), PP. $281-292$.

Gibson, James R. Feeding the Russian Fur Trade: Provisionment of the 0khotsk Seaboard and the Kamchatka Peninsula, $\frac{1639-1856}{16}$ Madison, MiIwaukee, and London: The University of Wisconsin Press, 1969.

Imperial Russia in Frontier America, The Chanqing Geography of Supply of Russian America, 1784-1867. New York: oxford University 
Golder, Frank A. Russian Expansion on the Pacific, 16411850. Gloucester, Mass.: Peter smith, 1960.

Gormly, Mary. "Early Cultural Contact on the Northwest Coast, 1774-1795: Analysis of Spanish Source Material," Northwest Anthropological Research Notes, 11, No. 1 (1977), Pp. 1-80.

Greenhow, Robert. History of Oregon and California. Boston: Freeman and Bolies, 1847.

Gunther, Erna. Indian Life on the Northwest Coast of North America As Seen by the Early Explorers and Fur Traders during the Last Decades of the Eighteenth century. Chic ago and London: The University of Chicago Press, 1972 .

Hamilton, Henry. The Enqlish Brass and Copper Industries to 1800. London: Frank Cass and co., Ltd., 1967.

Heizer, Robert F. "The Introduction of Monterey Shells to the Indians of the Northwest Coast," Pacific Northwest Quarterly, 31 (1940), pp. 399-402.

Archaeolooical Evidence of Sebastian Rodriquez Cermeño's California Visit in 1595. San Francisco: California Historical Society,

Howay, Fredrick W. "A List of Trading Vessels in the Maritime Fur Trade, 1785-1794," Iransactions of the Royal Society of Canada, 3rd ser., $\frac{\text { 24, sec. } 2}{111930), ~ p p . ~}$ 111-134.

"A List of Trading Vessels in the Maritime Fur Trade, 1795-1804," Transactions of the Royal Society of Canada, 3rd ser., 25, sec. 2 (1931), PP. 117-149.

Hume, Ivor Nö̈l. A Guide to Artifacts of Colonial America. New York: Alfred A. Knopf, 1970.

Jochelson, Waldemar. History, Ethnology and Anthropology of the Aleut, Carnegie Institution of washington Publication No. 432. Oosterhout S. B., The Netherlands: Anthropological Publications, 1968.

Jones, Roy $F$. Wappato Indians of the Lower Columbia River Kaeppler, Adrienne L., ed., and contributions by L. G. 
Rozina, Karl Henking, Enrico H. Giglioli; trans. Ella Wisweli, Denel Carr, Mildred M. Knolton. Cook Voyage Artifacts in Leningrad, Berne, and Florence Museums. Honolulu: Bishop Museum Press, 1978.

Keddie, Grant. NEvidence of Early Chinese Artifacts in British Columbia?" The Midden, 12, No. 5 (1980); and 13 , No. 2 (1981).

\section{"The Reliability of Dating} Archaeological and Ethnographic Materials with Assoeiated Chinese Coins," Datum, 3, No. 2 (1978).

Keith, Donald H., and Christian J. Buys. "New Light on Medieval Chinese Seagoing Ship Construction," The International Journal of Nautical Archaeology and Underwater Exploration, 10, No. 2 (1981), pp. $119-$ 132 .

Kemp, Peter, ed. The Oxford Companion to Ships and the Sea. London, New York, Melbourne: Oxford University Press, 1976.

Kendrew, W. G. The Climates of the Continents. New York: Oxford University Press, 1942.

Khlebnikov, K. T. Baranov, Chief Manager of the Russian Colonies in America, trans. Colin Bearne, ed. Richard A. Pierce. Kingston, Ontario: The Limestone Press, 1973.

Krause, Aurel. The Tlingit Indians, Results of a Trip to the Northwest Coast of America and the Bering straits, trans. Erna Gunther. Seattle and London: University of Washington Press, 1972.

Landström, Björn. Sailing Ships. Garden City, N. Y.: Doubleday and Co., 1978.

Lantis, Margaret. "The Aleut Social System, 1750 to 1810, from Early Historical Sources," Ethnohistory in Southwestern Alaska and the Southern Yukon: Method and Content, Studies in Anthropology, $\frac{\text { (1970), The }}{7 \text { (190 }}$ University Press of Kentucky, pp. 141-301.

Leen, Daniel. "The Rock Art of Western Washington," Northwest Anthropological Research Notes, 15, No. 1 (1981), PP. $1-56$.

Lensen, George Alexander. The Russian Push Toward Japan: Russo-Japanese Relations, 1697-1875. Princeton, 
N. J.: Princeton University Press, 1959

Macintosh, Duncan. Chinese Blue and White Porcelain. Rutland, Vt.: Charles E. Tuttie Co., 1977.

McDonald, George F. "Haida Burial Practices: Three Archaeological Examples: The Gust Island Burial Shelter; The Skungo Cave, North Island; Mass Burials from Tanu," Mercury Series, Archaeological Survey of Canada, Paper No. 9. National Museum of Man, National Museums of Canada, Ottawa, 1973.

McDonald, Lucile. "The Sonora," Alaska, 39, No. 2 (1973).

McEwan, Gordon F., and D. Bruce Dickson. "Valdivia, Jomon Fishermen, and the Nature of the North Pacific: Some Nautical Problems with Meggers, Evans, and Estrada's (1965) Transoceanic Contact Thesis," American Antiquity, 43, No. 3 (1978), Pp. 362-371.

Makarova, Raisa V. Russians on the Pacific, 1743-1799, trans. and eds. Richard A. Pierce and Alton S. Donnelly. Kingston, Ontario: The Limestone Press, 1975.

Mathes, W. Michael. Vizcaíno and Spanish Expansion in the Pacific, 1580-1630. San Francisco: California Historical society, 1968 .

Mertz, Henriette. Gods from the Far East: How the Chinese Discovered America (originaliy published as pale Ink). New York: Ballantine Books, 1975.

Morison, Samuel Eliot. "The Columbia's Winter Quarters of 1791-1792 Located," Oregon Historical Quarterly, 39, No. $1(1938)$, PP. $3-7$.

Niblack, Albert $P$. The Coast Indians of Southern Alaska and Northern British Columbia. New York: Johnson Reprint Corp., 1970.

Olson, Ronald L. "The Quinault Indians," University of Washington Publications in Anthropology, 6, No. 1 (1936), PP. 1-190.

Osborn, Douglas. River Basin Surveys Paper No. 8 , Excavations in the McNary Reservoir Basin Near Umatilla, Oregon. Washington, D. C.: U. S. Government Printing Office, 1957.

Pearson, Richard J. Archaeology of the Ryukyu Islands. Honolulu: University of Hawaii Press, 1969. 
Peattie, Donald Culross. A Natural History of Western Trees. Boston: Houghtion Mifflin Co., 1953.

Pethick, Derek. First Approaches to the Northwest Coast. Seattle and London: University of washington Press, 1979.

Phebus, George E. Letter to the author, published as "Konapee's Money?" Elicits Smithsonian Response," Screenings, 23, No. 2 (1974).

Quimby, George I. "Culture Contact on the Northwest Coast, 1785-1795," American Anthropologist, 50, No. 2 $(1948), \mathrm{PP} \cdot \overline{249-255}$

Ray, Arthur J. "History and Archaeology of the Northern Fur Trade," American Antiquity, 43, No. 1 (1978), PP. 26-34.

Ray, Verne F. "Lower Chinook Ethnographic Notes," University of Washington Publications in Anthropology, 7, No. 2 (1938), PP. 2 9-165.

"Cultural Relations in the Plateau of Northwestern America," publications of the Frederick Webb Hodge Anniversary publication Fund, $\frac{\text { Hen }}{3}$ (1939).

Rickard, T. A. "The Use of Iron and Copper by the Indians of British Columbia," British Columbia Historical Quarterly, 3, No. 1 (1939), pp. 25-50.

Schurz, William Lytle. The Manila Galleon. New York: E. P. Dutton and Co., 1959 .

Shangraw, Clarence, and Edward P. Von der Porten. The Drake and Cermeño Expeditions' Chinese Porcelains at Drakes Bay, California, 1579 and 1595. Santa Rosa and Palo Alto, California: Santa Rosa Junior College and Drake Navigators Guild, 1981.

Stafford, 0. F. "The Wax of Nehalem Beach," Dregon Historical Quarterly, 9, No. 1 (1908), pp. $\frac{24-41}{\text {. }}$

Stejneger, Leonhard. Georg Wilhelm Steller, The Pioneer of Alaskan Natural History. Cambridge, Mass.: Harvard University Press, 1936.

Swanton, John R. Indian Tribes of Washington, Oregon, and

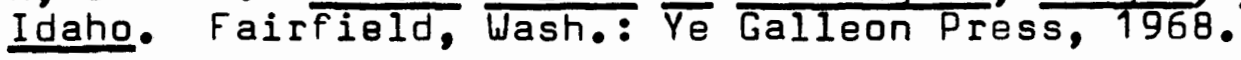


Thurman, Michael E. The Naval Department of San Blas, New Spain's Bastion for Alta California and Nootka, 17671798. Glendale, Calif.: The Arthur H. Clark Co., 1967 .

Tikhmenev, P. A. A History of the Russian-American Com-

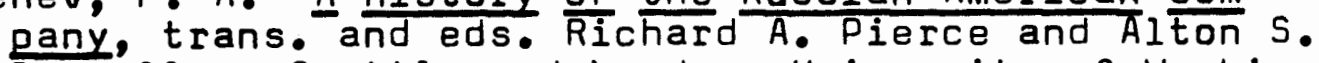
Donnelly. Seattle and London: University of Washington Press, 1978.

Vaughan, Thomas, E. A. P. Crownhart-Vaughan, and Mercedes Palau de Iglesias. Voyages of Enlightenment, Malaspina on the Northwest Coast, 1791-1792. Portland: Oregon Historical Society, 1977 .

Wagner, Henry R. Cartography of the Northwest Coast of America to the Year 1800, 2 vols. Berkeley: University of California Press, 1937 (rpt. N. Israel, 1968).

" "Creation of Rights of Sovereignty Through Symbolic Acts," Pacific Historical Review, 7, No. 4 (1938), pp. 297-326.

Willey, Gordon R. An Introduction to American Archaeology, 2 vols. Edgewood Cliffs, N. J. : Prentice-Hall, Inc., 1966.

Witthoft, John, and Frances Eyman. Tlingits, Dene, and Eskimo," Expedition, 11, No. 3 $(1969)$, pp. 12-23.

Woodward, Arthur. Denominators of the Fur Trade. Pasadena, Calif.: Westernlore $\frac{\text { Press, }}{1970}$.

Woodward, John, and Herbert K. Beals. "Fur Trade Symbols: A Glimpse from the Gladstone Graves," Proceedings of the First Annual Symposium of the Association of Dreoon Archaeolonists, Dccasional Papers No. $1,1980$.

Yeoman, R. 5. A Guide Book of United States Coins, 28 th ed. Raciñe, Wis.: Western Publishing Co., 1975. 


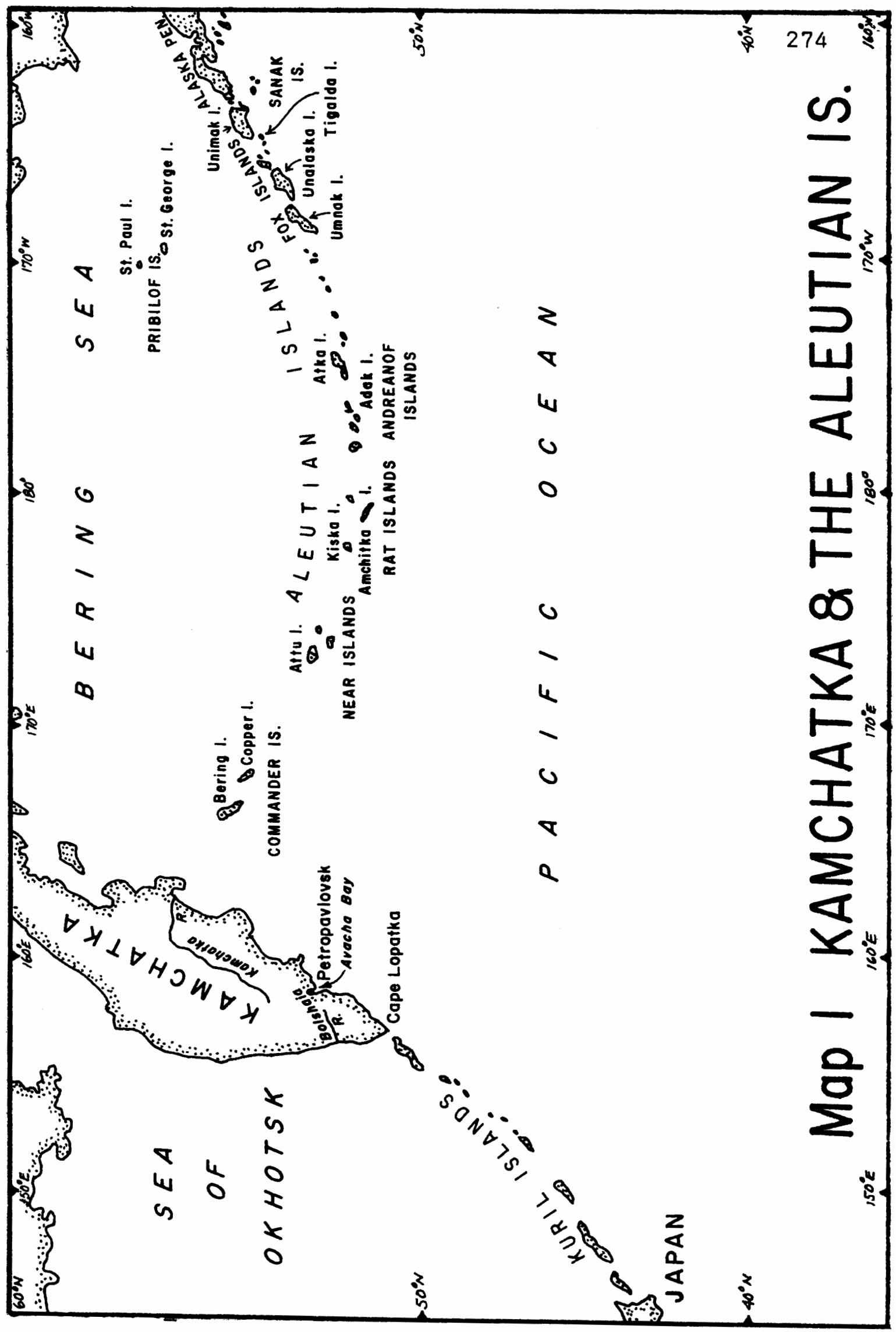




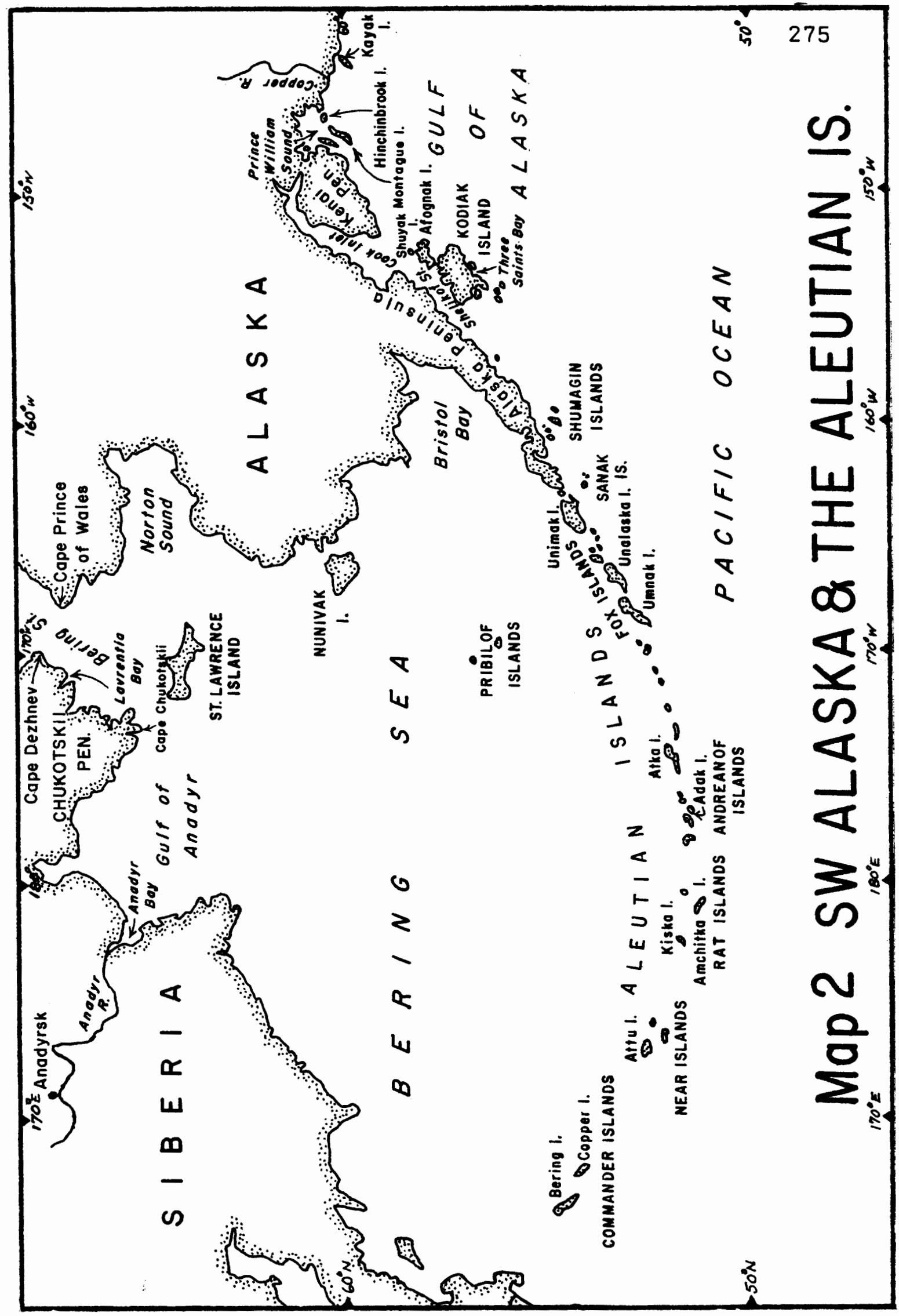




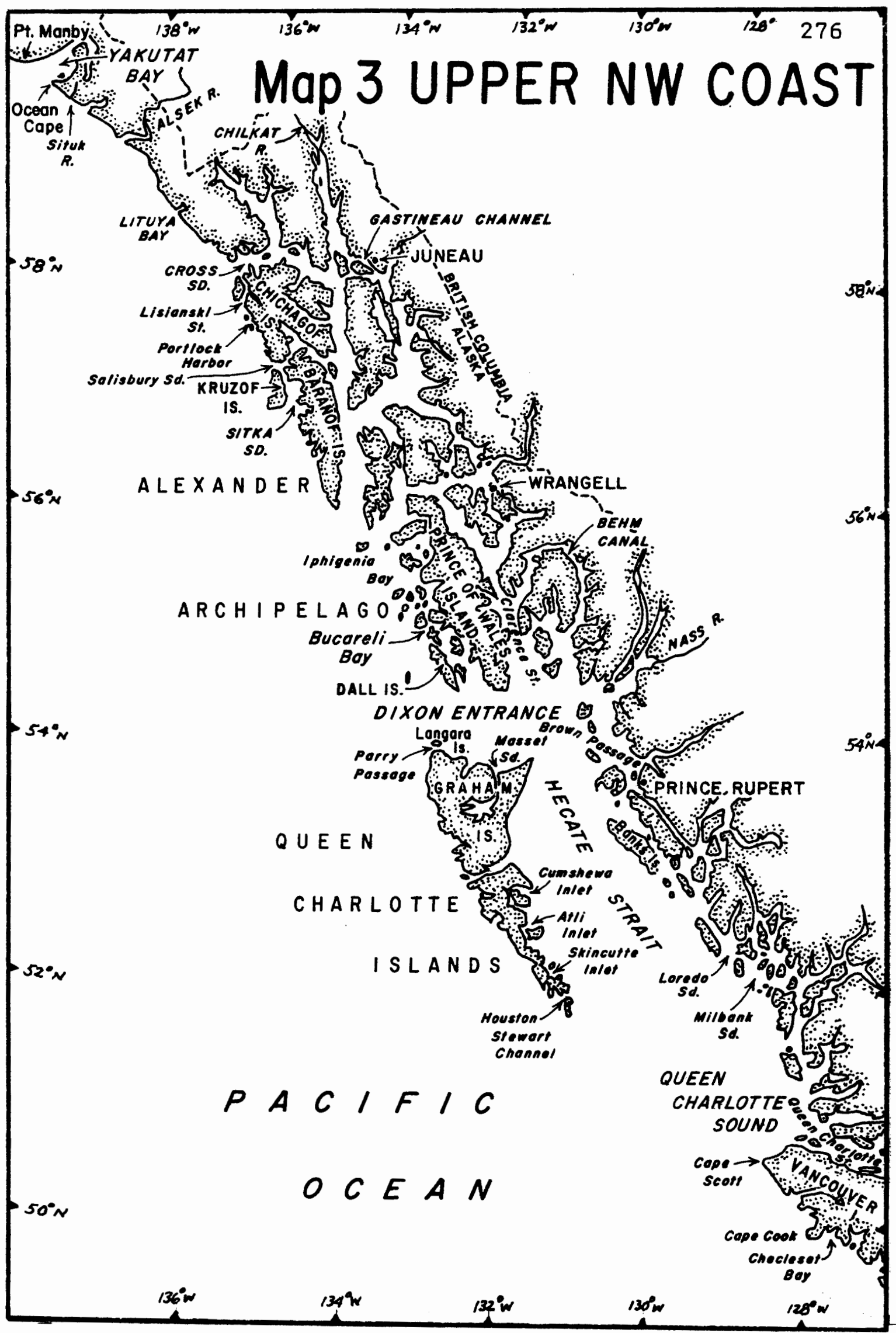






